Universidade de São Paulo

Faculdade de Educação

Claudia Lopes da Silva

\title{
Concepção histórico-cultural do cérebro na obra de Vigotski
}


Claudia Lopes da Silva

\section{Concepção histórico-cultural do cérebro na obra de Vigotski}

Tese apresentada à Faculdade de Educação da Universidade de São Paulo para a obtenção do título de Doutora em Educação

Área de concentração: Psicologia e Educação

Orientadora: Prof. ${ }^{a}$ Dr. ${ }^{a}$ Teresa Cristina Rego

São Paulo

2012 
Autorizo a reprodução e divulgação total ou parcial deste trabalho, por qualquer meio convencional ou eletrônico, para fins de estudo e pesquisa, desde que citada a fonte.

Catalogação na Publicação

Serviço de Biblioteca e Documentação

Faculdade de Educação da Universidade de São Paulo

37.046 Silva, Claudia Lopes da

S586c Concepção histórico-cultural do cérebro na obra de Vigotski / Claudia Lopes da Silva ; orientação Teresa Cristina Rego. São Paulo : s.n., 2012. $275 \mathrm{p}$.

Tese (Doutorado - Programa de Pós-Graduação em Educação. Área de Concentração : Psicologia e Educação) - Faculdade de Educação da Universidade de São Paulo)

1. Vigotski, Lev Semenovich, 1896-1934 2. Psicologia educacional 3. Psicologia - História - Cultura 4. Neurociências - Educação 5. Cérebro I. Rego, Teresa Cristina, orient. 
SILVA, Claudia Lopes da

Concepção histórico-cultural do cérebro na obra de Vigotski

Tese apresentada à Faculdade de Educação da Universidade de São

Paulo para a obtenção do título de Doutora em Educação

Aprovada em:

Banca Examinadora

Prof. Dr.

Instituição:

Julgamento:

Assinatura:

Prof. Dr.

Instituição:

Julgamento:

Assinatura:

Prof. Dr.

Instituição:

Julgamento:

Assinatura:

Prof. Dr.

Instituição:

Julgamento:

Assinatura:

Prof. Dr.

Instituição:

Julgamento:

Assinatura: 
Instruções para desencravar palavras

convém escavar das palavras um arrebol nítido solfejo de vertida voz no horizonte onde pássaros insones pousados hitchcockmente organizam em clave de sol seu bemol

cumpre vasculhar em seus escombros os resquícios de um eco sujo prenhe de vento varrendo o branco de nudez e intento tempestades esferográficas em assombro

carece encostar no desamparo da fala no que ela de canto bebe e transborda para além da margem cumpre em horda os descampados da celulose em que cala

compete à mão que vacila e alça o vôo provisório e intacto dessa matéria vasculhando abaixo da pele suas artérias no que da sombra à tona lança

corrobora no que de palavras o dia já tudo quanto a noite arfando ainda as vergonhas da página finda no esparramar de sintaxes lá

conjura o quanto das palavras em seu estado de dormência obscura faz dos arranjos possíveis dessa magia voraz consumir da vontade seu quinhão também

(Silvio J. Pedro) 


\section{AGRADECIMENTOS}

Agradeço inicialmente à Universidade de São Paulo. Assim como é mais fácil um camelo passar pelo buraco de uma agulha do que um rico entrar no reino dos céus, também é raro uma aluna egressa da educação básica pública brasileira como eu obter um título de Doutora na maior universidade pública de nosso país, motivo digno de profundo orgulho.

Dificilmente encontrarei as melhores palavras para agradecer minha orientadora, a Prof ${ }^{a}$. Dra . Teresa Cristina Rego. Agradeço sua competência e seriedade acadêmica, o olhar arguto e doce, e as contribuições críticas e potentes na orientação desta tese. Além do que, numa gentileza astrológica extra, tem o Sol em conjunção com meu Ascendente, a melhor sinastria entre uma orientadora e uma orientada.

Expresso profundo agradecimento à Prof ${ }^{a}$. Dr ${ }^{\mathrm{a}}$. Marta Kohl de Oliveira, da Faculdade de Educação da USP, pelas valiosas contribuições realizadas no exame de qualificação desta tese. Vindas de uma pessoa com sua estatura científica, converteram-se em lanternas preciosas durante o caminho.

Agradeço ao Prof. Dr. Hamilton Haddad, do Instituto de Biociências da USP, também participante da banca do exame de qualificação desta tese. Além de competente, é uma pessoa ousada, com coragem suficiente para entrar nos nebulosos e pantanosos limites entre educação e neurociência.

Agradeço às contribuições feitas a esta tese durante seu projeto e processo de escrita, em especial ao Sandro Henrique Vieira de Almeida, à Marisa Russo e ao professor Achilles Delari Junior. Fica aqui também uma lembrança especial àquelas pessoas que, além das aqui citadas, contribuíram para meu crescimento científico, entre as quais destaco Paulina Cymrot, Carla Adda, Sueli Rossini, Marilene Proença, Elenita de Ricio Tanamachi, Maria Isabel da Silva Leme, Rosângela Prieto, Marie Claire Sekkel, Yara Sayão e Liliane Garcez.

Meus sinceros agradecimentos também às pessoas envolvidas profissionalmente comigo e que me proporcionaram as condições necessárias para que eu pudesse dedicar-me à escrita desta tese mantendo, ao mesmo tempo, minha atividade profissional. Cito em especial as professoras Elizabete Tavares, Denise Marino e Doroti de Oliveira Rosa Macedo, da Unimes Virtual, pela oportunidade de trabalho a mim oferecida como docente, viabilizando o afastamento temporário do meu cargo público, além da querida amiga Heloísa de Oliveira 
Prado, que me indicou para a instituição, trazendo-me enorme satisfação. Aproveito para agradecer às profissionais da Secretaria de Educação de São Bernardo do Campo que emitiram parecer favorável ao meu pedido de licença para que eu pudesse me dedicar ao Doutorado, em especial à secretária de educação Cleuza Repulho, à diretora do Departamento de Ações Educacionais Stella Chicchi, à chefe da Seção de Educação Especial Cecília de Oliveira Prado e às queridas companheiras de trabalho Virginia Marino e Priscila Varella que, ainda que tenham se entristecido com a minha saída da equipe, sempre torceram por mim.

Agradeço à leitura criteriosa (e alheia a qualquer tipo de favorecimento fraterno) realizada por minha irmã, Paula Lopes da Silva, que além de filósofa e professora possui domínio raro da língua portuguesa. Também agradeço a revisão do abstract feita pela minha irmã Rosana Lopes da Silva, que entre outros talentos é pianista e também professora. Com irmãs como essas, fica fácil apresentar um trabalho bem finalizado.

Agradeço ainda aos colegas do GENE - Grupo de Estudos de Neurociência e Educação, da USP, Hamilton Haddad e Bárbara Milan. O interesse pela pesquisa em neurociência e educação fez com que nos conhecêssemos naquele encontro da SBNeC em Caxambu, em 2010, e a parceria tem dado frutos. Também agradeço ao Guilherme Brockington, que me encontrou pelo tema de Doutorado na FEUSP. Ainda vamos produzir muita coisa, nos aguardem!

Agradeço e ofereço esse trabalho com amor a minha querida família, pequena e unida: Ivany, Lucy, Paula, Rosana e Flora, Moacir, Anibal e Diogo, e à memória da nossa amada e sempre presente Filó. Estendo para Sebastião, Rosa Maria, Rita, Juan e Marco, família ampliada e estimada.

Por fim, agradeço ao meu marido, o poeta Silvio José Pedro, cuja poesia ilustra a dedicatória desta tese e meus dias. 
Mas, se queremos, na realidade, saber o que são o pensamento e a consciência e de onde procedem, saberemos, então, que são produtos do cérebro, e o próprio homem nada mais é do que um produto natural que se formou e se desenvolveu dentro de seu ambiente e com ele.

(Engels, 1878)

Damo-nos cada vez mais conta da manifesta diversidade e do caráter inconcluso das funções cerebrais. É muito mais correto admitir que o cérebro encerra enormes possibilidades para o aparecimento de novos sistemas. Essa é a principal premissa.

(Vigotski, 1930)

Não se pode esperar encontrar a fonte da ação livre nos reinos etéreos da mente ou nas profundezas do cérebro. A abordagem idealista dos fenomenologistas é tão infrutífera quanto a abordagem positivista dos naturalistas. Para descobrir as fontes da ação livre é necessário ir além dos limites do organismo - não à esfera íntima da mente, mas às formas objetivas da vida social. É necessário procurar as fontes da consciência e da liberdade humana na história social da humanidade. Para encontrar a alma, é necessário perdê-la.

(Luria, 1966)

O cérebro é a essência do que somos. Ele define tudo o que chamamos de humanidade, as características e os comportamentos que ao mesmo tempo nos identificam como indivíduo único e também como parte de uma espécie. Ao mesmo tempo que nos dá essa assinatura quase egoísta da individualidade, ele nos fornece a garantia de pertencer a um coletivo. É acessível para um indivíduo e para o resto da humanidade, e poucas coisas no universo, que a gente saiba, têm essa característica.

(Miguel Nicolelis, 2008) 


\section{RESUMO}

SILVA, C. L. Concepção histórico-cultural do cérebro na obra de Vigotski. 2012. $275 f$.

Tese (Doutorado) - Faculdade de Educação, Universidade de São Paulo, São Paulo, 2012

Esta tese procura identificar o conceito de cérebro na obra de Vigotski, analisando como este conceito relaciona-se com os fundamentos da psicologia histórico-cultural. A partir disso, discute possíveis implicações desse conceito para a educação, face a um cenário educacional onde as relações entre neurociência e educação recebem atenção crescente de ambos os campos. Trata-se de um trabalho teórico, baseado na produção teórica de Vigotski realizada no período de 1924 a 1934, ano de sua morte. Entre as dezenas de obras conhecidas do psicólogo bielorrusso, foram selecionados e analisados vinte textos nos quais o tema cérebro é abordado de forma mais particularizada. A partir dessa análise, pôde-se concluir que as teorias de Vigotski sobre o cérebro estão intrinsecamente relacionadas com os fundamentos da psicologia histórico-cultural. A abordagem vigotskiana do cérebro se deu de forma densa e inovadora, considerando o que se conhece atualmente a partir das descobertas da neurociência. Entre estas ideias, pode-se destacar a constituição da consciência a partir da internalização da experiência social, o funcionamento cerebral através de sistemas funcionais em oposição à visão localizacionista, os sinais como conexões extra-cerebrais de origem cultural e a defesa do monismo psicofísico, entre outros, caracterizando uma abordagem materialista da psique que entende o cérebro como a base material da consciência. Destaca-se a importância de considerar como parte da fundamentação da obra vigotskiana sua concepção sobre o humano enquanto organismo, o que não implica necessariamente em uma visão reducionista - pelo contrário, a fundamentação filosófica materialista e marxista de Vigotski o exige. No que se refere à educação, debate-se a importância de reconhecer que a relação com a neurociência não deve servir como uma roupagem atual para a medicalização e patologização das relações escolares, ousando-se propor que, se alguma contribuição pode ser feita pela neurociência à educação, que seja a favor da defesa da potencialidade para o aprendizado de todos os alunos e alunas.

Palavras-chave: Vigotski. Psicologia histórico-cultural. Neurociência e Educação. Cérebro. 


\begin{abstract}
SILVA, C. L. Brain historical-cultural conception in Vygotsky's work. 2012. 275f. Tese

(Doutorado) - Faculdade de Educação, Universidade de São Paulo, São Paulo, 2012.

This thesis covers the concept of brain in the work of Vygotsky, analyzing how this concept relates to the foundations of cultural-historical psychology. It also discusses the possible educational implications of this approach, taking into account an educational setting where relationships between neuroscience and education receive increased attention from both camps. It is a theoretical work, based on Vygotsky's production in the period 1924 to 1934, the year of his death. Among the dozens of known works of the Belarusian psychologist, were selected and analyzed twenty texts in which the brain is the topic addressed in a more particularized. From this analysis, we concluded that Vygotsky's theories on the brain are deeply related to the foundations of cultural-historical psychology. His approach to the brain occurred in a dense and innovative, even considering what is currently known from the discoveries of neuroscience. Among these ideas, we can highlight the creation of consciousness from the internalization of social experience, brain function through functional systems as opposed to localizing view, the signals as extra-cerebral connections of cultural and defense of psychophysical monism, among other, featuring a materialist approach that understands the psyche of the brain as the material basis of consciousness. We emphasize the importance of considering as part of the grounds of its design work on the Vygotskyan as human body, which does not necessarily imply a reductionist view - on the contrary, the philosophical foundation of Marxist materialism and Vygotsky demands. In relation to education, debate the importance of recognizing that the relationship with neuroscience should not serve as a guise for the current medicalization and pathologizing school, daring to propose that if a contribution can be made by neuroscience to education, that is in favor of the defense capability for the learning of all pupils and students.
\end{abstract}

Keywords: Vygotsky. Cultural-Historical Psychology. Neuroscience and Education. Brain. 
2.3 Uma questão de método: os fundamentos da psicologia histórico-cultural no materialismo histórico-dialético 63 
3.1 Vigotski e o cérebro enquanto base material da consciência ..................................... 77

3.1.1 Primeiro momento. Palavras-chave: REFLEXO e CONSCIÊNCIA .......................... 81

3.1.2 Segundo momento. Palavra-chave: INSTRUMENTO ........................................ 82

3.1.3 Terceiro momento. Palavra-chave: FUNÇÕES PSICOLÓGICAS SUPERIORES ..... 84

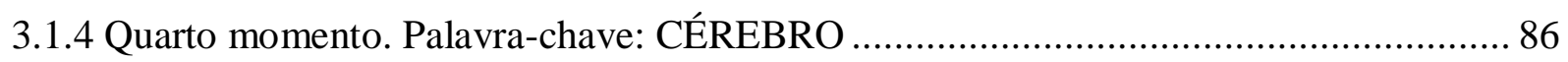

4 O CONCEITO DE CÉREBRO NA OBRA DE VIGOTSKI .................................. 88

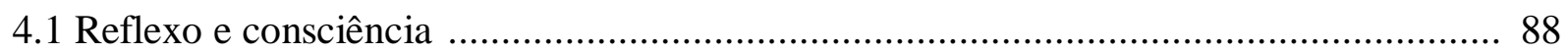

4.1.1 Os métodos de investigação reflexológicos e psicológicos (1924) ............................ 88

4.1.2 A consciência como problema da psicologia do comportamento (1925) .................... 93

4.1.3 Prólogo à versão russa do livro de E. Thorndike, "Princípios de ensino baseados

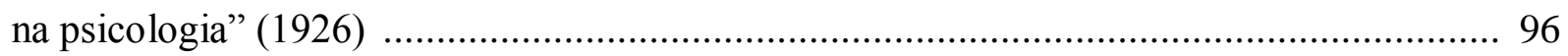

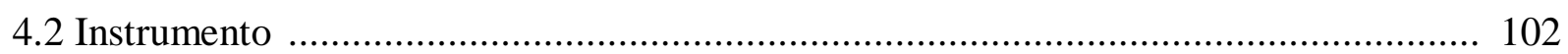

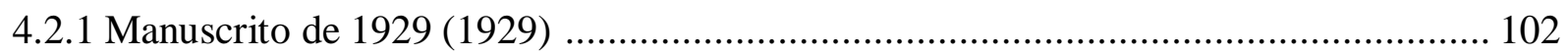

4.2.2 O problema do desenvolvimento cultural da criança (1929) ................................... 113

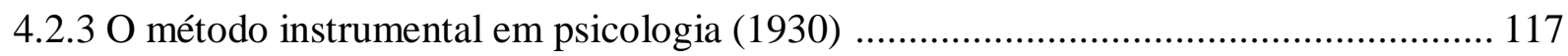


4.2.5 Sobre os sistemas psicológicos (1930)

4.2.6 Estudos da história do comportamento: símios, homem primitivo e criança (1930) .. 124

4.3 Linguagem

4.3.1 História do desenvolvimento das funções psíquicas superiores (1931)

4.3.3 O primeiro ano (1932)

4.4 Cérebro

4.4.1 O problema mente-corpo (1932)

4.4.2 Sobre localização (1934)

4.4.3 A psicologia e a teoria da localização das funções psíquicas (1934)

4.4.4 O problema do desenvolvimento e da desintegração das funções psíquicas superiores (1934)

4.4.5 O pensamento na esquizofrenia (1931) 
6 NEUROCIÊNCIA E EDUCAÇÃo SOB O ENFOQUE DA PSICOLOGIA

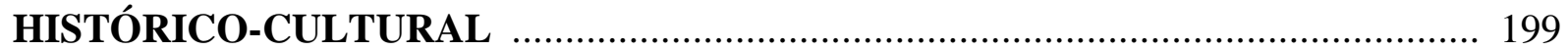

7 CONSIDERAÇÕES FINAIS: "FINIS CORONAT OPUS"

REFERÊNCIAS

Apêndice 1 


\section{INTRODUÇÃO}

A história, ao mudar o tipo humano, depende do córtex; o novo homem socialista será criado através do córtex; a educação é, em geral, uma influência sobre o córtex.

(Vigotski $\left.{ }^{l}\right)$

O leitor pode perguntar-se, ao iniciar a leitura: mais um trabalho sobre Vigotski? $\mathrm{Eu}$, em seu lugar, perguntaria. A obra de Vigotski é palco de um fenômeno interessante: ao mesmo tempo em que é bastante popularizada, é conceitualmente sofisticada, e apesar de existirem vários trabalhos publicados com base na psicologia histórico-cultural proposta por Vigotski, ainda permanecem algumas lacunas inexploradas, que convivem com outras temáticas bastante discutidas e reproduzidas, principalmente no Brasil. Nesse sentido, acredito que lançar uma pesquisa com base na psicologia histórico-cultural vigotskiana deve acrescentar algo, adentrando as searas inexploradas da obra do autor, ainda que tais movimentos sejam sempre acompanhados de certos riscos.

De forma honestamente despretensiosa, desejo que esta tese seja considerada dentro dessa perspectiva. Os temas tratados nesta pesquisa - neurociência, educação e psicologia histórico-cultural - não são simples, e os campos epistemológicos tangenciados são muitas vezes contraditórios: como a leitura científica por vezes reducionista da neurociência e o campo filosófico da educação e da psicologia podem conversar? Este desafio, no entanto, não intimidou Vigotski, que discutiu o assunto de forma profunda há cerca de oitenta anos, o que influenciou de forma decisiva sua obra, como pretendo demonstrar.

\footnotetext{
${ }^{1}$ Apud Van der Veer e Valsiner, 2001, p.347.
} 
Acredito ser pertinente iniciar contando um pouco do meu percurso acadêmico e profissional, e em que momento esse caminho encontra Vigotski e sua obra, encontro que desperta o interesse pela temática aqui desenvolvida.

Graduei-me em psicologia pelas Faculdades Metropolitanas Unidas em 1998, após uma trajetória profissional em outro campo de trabalho, de publicidade e artes gráficas. Antes disso, minha experiência com educação limitava-se a um primeiro emprego em uma escola particular de Educação Infantil e Ensino Fundamental, aos dezoito anos de idade. No segundo dos três anos em que fiquei no emprego, assumi a regência de uma turma de quarto ano, experiência que me marcou profundamente. No outro período, na mesma escola, trabalhava na produção de materiais didáticos, ilustrando apostilas e confeccionando cartazes. Este segundo lado acabou sobressaindo-se, e fui seguir a carreira de produtora gráfica e diretora de arte. Algumas idas e vindas depois, acabei cursando a faculdade de psicologia. A educação continuava um campo distante, ao qual não cogitava retornar. Lembro inclusive de ter negociado num sebo, ao final do curso, um exemplar da primeira edição de Introdução à psicologia escolar, de Maria Helena Souza Patto - que, junto com alguns outros livros, foi trocado por Narrativa da análise de uma criança, de Melanie Klein, meu interesse na época.

Profissionalmente, inclinava-me para a área institucional. Cogitava trabalhar em algum serviço público que oferecesse atendimento psicológico ou algo do gênero. Devido a isso, no ano seguinte acabei ingressando no curso de aprimoramento em Psicologia Hospitalar no Hospital das Clínicas da Faculdade de Medicina da Universidade de São Paulo, um curso estilo residência, com dedicação integral (oito horas por dia) e com bolsa da Fundap Fundação de Aperfeiçoamento de Pessoal do Estado de São Paulo. Coube a mim o estágio no ambulatório de Neurologia, onde atendia pacientes adultos do grupo de esclerose múltipla e da clínica do sono (com narcolepsia, insônia e outras questões), bem como aplicava testes e outras avaliações neuropsicológicas. Mas a atividade em que mais me envolvi foi o trabalho na ala da neuropediatria, onde acompanhava as crianças internadas e suas acompanhantes, na grande maioria mães, tendo daí produzido a monografia de conclusão de curso Mães acompanhantes de crianças hospitalizadas. Investia paralelamente numa formação e supervisão em psicanálise kleiniana, que era a fundamentação teórica que me orientava na clínica.

Com o final do curso de especialização surgiu a oportunidade de prestar um concurso público na área de educação, como psicóloga escolar - onde vislumbrei a 
oportunidade de continuar a exercer um trabalho institucional, desta vez vinculada ao serviço público. A colega que comentou sobre o concurso advertiu: "precisa ter três anos de experiência em educação" - e era justamente o que eu tinha. Para minha sincera surpresa, fui aprovada em quarto lugar, e chamada logo no início de 2000. Foi de fato uma ironia, pois trabalhar com Educação era a última coisa em que eu pensaria ao terminar a graduação. Contudo, quinze anos após a experiência com a quarta série, lá estava eu na educação novamente, embora em um contexto completamente diferente.

Ingressei em janeiro daquele ano na Secretaria de Educação de São Bernardo do Campo, como parte da equipe de orientação técnica. Inicialmente, trabalhei na seção de programas educacionais, com temas como educação ambiental e trabalho com escola e comunidade, focada na formação de professores. Conheci a rede de ensino e suas peculiaridades, fui me acostumando e me envolvendo cada vez com o novo trabalho.

Em 2002, passei a integrar a equipe de orientação técnica do Ensino Fundamental e a fazer um trabalho nas unidades escolares junto às equipes gestoras e professores. O objeto básico do meu trabalho era a queixa escolar na sua forma "clássica", ou seja, a culpabilização do aluno pelas dificuldades no processo de escolarização. Foi nesse momento em que me arrependi de ter trocado o livro de Patto pelo de Klein, que empoeirava na estante. Assim, no mesmo ano parti para minha segunda especialização, em psicologia e educação, no Instituto de Psicologia da Universidade de São Paulo, e comprei um exemplar novo de Introdução à psicologia escolar. Durante a especialização, outro autor passou a frequentar minha estante: Lev Semionovitch Vigotski, por quem comecei a nutrir um grande entusiasmo teórico.

Entre as minhas funções na equipe de orientação técnica, estava o acompanhamento às situações de inclusão escolar de alunos com deficiência e transtornos do desenvolvimento, que envolvia também o acompanhamento do trabalho de professores especializados em educação especial que atuavam em sala de recursos, trabalhando com alunos com deficiências vinculadas ou não a causas orgânicas.

$\mathrm{O}$ assunto educação inclusiva dominou meus interesses, a ponto de levar-me a dar continuidade a meus estudos, no final da especialização, com o ingresso no mestrado em Psicologia Escolar, no mesmo Instituto de Psicologia da Universidade de São Paulo, em 2004. Neste trabalho, sob orientação da Prof. ${ }^{a}$ Dr. ${ }^{a}$ Maria Isabel da Silva Leme, investiguei o papel do diretor escolar na implantação de uma cultura escolar inclusiva, utilizando a psicologia histórico-cultural como fundamentação teórica, tendo concluído o mesmo em 2006. Comecei 
a estudar o autor de forma mais sistemática, participando, de 2005 a 2008, do grupo de estudos sobre Vigotski do Laboratório Interinstitucional de Estudos e Pesquisas em Psicologia Escolar - LIEPPE, vinculado ao Instituto de Psicologia da Universidade de São Paulo, sob coordenação da Prof. ${ }^{\text {a }}$ Dra. Elenita de Rício Tanamachi.

Paralelamente, na minha atividade profissional, observava que o processo da implantação das estratégias de apoio na escola comum para alunos com deficiência estava se fortalecendo naquele momento, mas a postura da rede municipal era vacilante, pois ainda eram mantidos serviços de atendimento segregados, como as escolas especiais. Os professores especializados eram provenientes dessa realidade, e tinham pouca ou nenhuma experiência com a escola comum, ou com as necessidades decorrentes da inclusão do aluno com deficiência nesse novo contexto. Assim, suas necessidades formativas eram prementes. Aliás, todos nós, naquele momento, estávamos tateando esse desafio. No entanto, minha única certeza era a do direito dessas crianças à escola comum, e que a nós, profissionais do sistema, cabia fazer as adequações necessárias para isso.

Certa vez, em uma aula na qual participavam algumas dessas professoras, entrei em um debate com uma delas que afirmava necessitar do diagnóstico de um neurologista para saber qual a capacidade de memória que o aluno dispunha, a partir do que orientaria seu trabalho até o limite em que poderia ir com o aluno. Na ocasião, apontei os equívocos em sua concepção baseada em alguns dados de pesquisas neurocientíficas, como a neuroplasticidade e a potencialidade de atualização constante do sistema nervoso central, que apenas declina com os anos mas nunca pára: a capacidade de aprender acompanha o ser humano até a morte. Cogitei que os pressupostos ideológicos de sua fala dificultavam que percebesse as evidências científicas do que eu estava dizendo. Por outro lado, achei interessante utilizar argumentos do mesmo campo científico para combater a alegada necessidade de um diagnóstico de limites potenciais do aluno. Ponderei que este mesmo campo de saber, a neurociência, pode servir para refutar ou reforçar diferentes pontos de vista, haja vista a impossibilidade da neutralidade da ciência. E já que é assim, por que não utilizar tais conhecimentos em defesa do direito de aprender do aluno?

Assim nasceu a motivação principal para esta tese de doutorado: por que os mesmos avanços da pesquisa neurocientífica não podem ser utilizados para enfatizar uma visão emancipatória do aluno, das suas diversas capacidades e potencialidades, ao invés das suas supostas deficiências? Esse episódio aconteceu por volta de 2004, quando eu estava no 
início do mestrado, mas a questão suscitada ficou aguardando uma oportunidade de ser mais bem ponderada, o que surgiu quando submeti um projeto com este escopo à Faculdade de Educação da Universidade de São Paulo e fui aprovada em 2008 para o Doutorado em Educação, na área Psicologia e Educação, sob orientação da Prof. ${ }^{a}$ Dr. ${ }^{a}$ Teresa Cristina Rego.

Inicialmente, meu interesse era motivado pelas relações entre educação e neurociência. Ao explorar um pouco mais esse campo, observei que os conhecimentos provenientes da neurociência - ou sua interpretação possível - têm quase sempre sido incorporados pela educação de forma ideológica, ou seja, como um argumento novo, científico, moderno e tecnológico a favor da justificativa da não aprendizagem. Essa manipulação não é nova nas relações entre a educação e as ciências da saúde, como anteriormente ocorreu com justificativas como carência de recursos, desnutrição, disfunção cerebral mínima e mais modernamente com os diagnósticos de dislexia, TDA-H - Transtorno do Déficit de Atenção e Hiperatividade e o novíssimo TOD - Transtorno OpositivoDesafiador. Como a neurociência veio ocupar este lugar?

O conhecimento acerca das descobertas no campo das neurociências tornou-se parte do dia-a-dia das pessoas. Presentes em telejornais de grande alcance e não só em revistas de divulgação científica, mas nas revistas semanais de grande tiragem, as notícias sobre os resultados de pesquisas envolvendo a neurociência tornaram-se de certa forma comuns. O aprimoramento de técnicas de neuroimagem, o desenvolvimento de pesquisas sofisticadas em nível molecular no sistema nervoso central promovendo o incremento de medicamentos com resultados eficazes no tratamento da depressão e do transtorno bipolar, a descoberta de propriedades químicas, elétricas e fisiológicas dos neurônios que superaram antigas visões da medicina, como a capacidade de determinadas regiões cerebrais assumirem funções de outras regiões lesionadas face à correta estimulação, enfim, esses avanços científicos caracterizaram os anos 1990, declarados como a Década do Cérebro por um decreto presidencial nos Estados Unidos.

Assim, debates técnicos e éticos acerca de questões extremamente específicas do ponto científico, como a pesquisa com células-tronco, por exemplo, acabaram fazendo parte do repertório cotidiano de pessoas comuns, ainda que as conquistas prometidas por tais pesquisas estejam em um horizonte distante. Divulgadas de forma muito resumida e polida, onde apenas as vantagens e promessas são destacadas, e relacionadas com o que podem significar em termos de avanços na cura de doenças ou recuperação de capacidades perdidas, 
as notícias sobre descobertas neurocientíficas acabam colaborando para a construção de um ideário que coloca a ciência como uma espécie de panaceia moderna, acenando com promessas de cura ou ainda de eterna juventude.

Examinando publicações de divulgação científica em educação, como a revista Nova Escola, podemos observar a presença constante de artigos que discutem temas da neurociência, ou ainda de referências a pressupostos desse campo de saber. Para citar um exemplo recente, destaco um trecho da coluna eletrônica da editora Paola Gentile (2007, s/p), de junho de 2007, onde se lê:

Certa vez, conversando com a neurologista ${ }^{2}$ e educadora Elvira Souza Lima, de São Paulo, ela me disse que os jovens de hoje são multimídia. Ou seja, são capazes de operar diversos canais cerebrais ao mesmo tempo, sem que um abafe o desempenho do outro. E que isso é quase "genético" nas novas gerações, super expostas às tecnologias, direta ou indiretamente. "Eles operam com várias 'janelas' abertas", declarou ela, usando termos da informática. Aliás, os professores de hoje são sempre incitados a variar a metodologia e os recursos usados em sala de aula, para que, durante o processo de ensino, vários sentidos sejam trabalhados e contribuam para o aprendizado. Afinal, isso é bom ou ruim? Aí vão os dois lados: se por um deles as crianças conseguem mobilizar várias áreas do cérebro, com relativa eficiência, por outro falta aquele silêncio, aquele momento em que as ideias se fixam no cérebro, em que fatos aparentemente isolados se ligam. Refirome à análise, ao tempo necessário para fazer um julgamento ou elaborar uma opinião. Será que com tantos dados entrando por diversos canais sobra espaço para a análise das informações?

Não pretendo aqui aprofundar a discussão acerca dos conceitos veiculados no trecho acima, mas utilizá-lo para caracterizar a presença cada vez mais comum de ideias e expressões relacionadas com o universo da neurociência na pedagogia.

A pergunta que orienta minha reflexão é: como a pedagogia, enquanto campo científico, se relaciona com as ideias da neurociência? Existe a intenção, ou vislumbra-se a possibilidade, de utilizar os conhecimentos da neurociência para incrementar os processos de aprendizagem? Supondo-se uma resposta afirmativa, qual o pressuposto epistemológico que

\footnotetext{
${ }^{2}$ Em seu blog (http://www.elvirasouzalima.net/) Elvira Souza Lima apresenta-se como "pesquisadora em desenvolvimento humano, com formação em neurociências, psicologia, antropologia e música", e não como neurologista, conforme afirma a reportagem. É possível que a jornalista Paola Gentile, que escreveu a matéria, tenha cometido esse engano justamente por conta do tipo de mecanismo que tende a usar os rótulos "neuro" com forma de qualificação, fenômeno que é discutido nessa tese (ver capítulo seis).
} 
sustenta essa apropriação, ou ainda, que bases epistemológicas possibilitam essa apropriação? E, a questão mais fundamental: qual a finalidade dessa apropriação?

Em um artigo publicado na revista Science em novembro de 2005, a professora de psicologia cognitiva e educacional Elsbeth Stern, do Instituto para o Desenvolvimento Humano Max Plank, na Alemanha, sustenta que atualmente os responsáveis pela implantação de políticas educacionais buscam nortear suas ações muito mais por evidências empíricas do que por ideologias ou opiniões. Essa busca por uma educação baseada em evidências coincidiu com os avanços no campo da neurociência, bem como com o interesse do público sobre esses avanços, levando ao questionamento sobre a aplicabilidade dos achados neurocientíficos na pedagogia.

Stern (2005) argumenta que tais expectativas podem ser irrealistas se não forem corretamente esclarecidas, comentando o modismo de se denominar como "aprendizagem baseada no cérebro" certos procedimentos cujos efeitos não foram estabelecidos cientificamente. Cita como exemplo a ideia de que as capacidades cognitivas das crianças pequenas poderiam ser aumentadas mediante uma estimulação audiovisual, que estaria baseada na evidência da intensa proliferação de sinapses durante o desenvolvimento cerebral na primeira infância, advertindo que não está claramente estabelecido o quanto tais tarefas de memorização desenvolvidas precocemente proporcionam uma diferença na aprendizagem em relação a outras crianças não expostas a esse tipo de intervenção. Esse tipo de uso de uma descoberta científica, além de criar expectativas pouco realistas, vem acompanhado do perigo adicional de que se passe a considerar de importância secundária as pesquisas empíricas no campo da educação, psicologia e tecnologia da informação, que têm até então proporcionado avanços no campo do ensino e da aprendizagem. A autora considera, contudo, que a neurociência pode contribuir para a aprendizagem dos alunos que não se beneficiam dos processos pedagógicos habituais, propondo que a pesquisa do cérebro pode levar ao conhecimento do que impede a aprendizagem. As técnicas de neuroimagem poderiam ajudar a esclarecer questões como a dislexia, e a neurociência poderia explicar como as experiências prévias afetam a aprendizagem de um ponto de vista diferente das explicações psicológicas, acredita Stern, que faz uma análise sensata ao apontar os perigos da supervalorização de descobertas ainda incipientes no campo da neurociência. Podemos criticar os riscos da sobreposição simplista de campos epistemológicos diversos como uma ciência humana como pedagogia e a neurociência de base biológica. Mas em sua fala aparece a ideia de que há uma 
possível explicação fisiológica para a dificuldade de aprendizagem que poderia ser elucidada pela pesquisa cerebral - e nesse ponto essa reflexão promete ficar bastante interessante.

Teoricamente, alinho-me com uma visão crítica da educação, que questiona a atribuição das supostas dificuldades de aprendizagem aos alunos, buscando neles as causas do insucesso do processo de escolarização. As pesquisas nesse campo, entre as quais destaco o trabalho referencial de Patto (1999), bem como os de Souza (1996), Machado (1994) e Collares e Moysés (1996), denunciam a busca ideológica de supostos fatores biológicos que explicariam as dificuldades escolares dos alunos em detrimento das causas sociais envolvidas, que posso resumir muito grosseiramente como os preconceitos da escola em relação às crianças das camadas populares e a manutenção de um sistema educacional excludente em suas bases. Assumindo-se esse ponto de vista, torna-se questionável a ideia de que os avanços das técnicas de neuroimagem possam ajudar a elucidar a localização cerebral de presumidas dificuldades de escolarização.

No entanto, esse tipo de pensamento parece estar em franco desenvolvimento no Brasil, a julgar pelo crescente número de congressos e cursos enfocando temas como "neuropedagogia", a exemplo do que já ocorre nos Estados Unidos, onde a aprendizagem baseada no cérebro, ou "brain-based learning" é uma corrente educacional influente, com vários materiais, publicações e cursos sendo comercializados.

Observei também, ao propor meu tema de pesquisa, que parece haver certa aceitação de que tais conhecimentos da neurociência estejam alinhados com a psicologia cognitiva de base behaviorista, bem como uma pedagogia de base comportamental, campos derivados de uma base epistemológica comum, que é a ciência comportamental. A minha proposta inicial, no entanto, contrariando tais expectativas, foi fazer uma leitura dessa questão na perspectiva da psicologia histórico-cultural de Vigotski, o que me pareceu perfeitamente plausível, dado o grande espaço dedicado pelo autor ao estudo neurocientífico.

Logo no início da pesquisa para o projeto, ainda antes do doutorado, percebi que o campo estava bastante inexplorado, havendo poucos trabalhos abordando a relação entre neurociência e educação na perspectiva da psicologia histórico-cultural. Encontrei basicamente dois textos produzidos por autoras brasileiras, Morales (2005) e Coelho (2006). Morales (2005) discorre sobre as interlocuções da obra de Vigotski e Luria (entre outros autores) com conceitos como a plasticidade neuronal, e as possíveis implicações disso para a educação e para a sala de aula de forma específica, notadamente no que se refere aos 
processos de aprendizagem. Em seu texto Cérebro e psiquismo, Coelho (2006) discute algumas questões atuais da neuropsicologia com destaque para a abordagem históricocultural. Entre as questões elencadas, estão a relação entre os fenômenos psíquicos e a atividade cerebral, a constituição e organização dos processos psicológicos superiores e os diferentes processos de integração dos diferentes fenômenos psíquicos. A autora classifica os aportes da psicologia histórico-cultural oferecidos por Vigotski e Luria como relacionados com as propostas do modelo sistêmico social, que pressupõem a existência de correlações entre cérebro e a dinâmica psíquica. Resume as contribuições dos dois teóricos apontando o critério cronogênico no desenvolvimento do psiquismo, o funcionamento sistêmico do cérebro em oposição ao localizacionismo, a importância das condições objetivas da existência humana na formação das funções psíquicas e o papel fundamental da linguagem enquanto critério instrumental.

Uma justificativa plausível para a o número reduzido de trabalhos nessa área é que a maior parte dos trabalhos sobre Vigotski produzida no Brasil e relacionada à pesquisa em Educação volta-se para uma leitura sociológica e pedagógica do autor. Pode-se encontrar com relativa frequência trabalhos sobre alguns temas específicos explorados por Vigotski, como sentido e significado, por exemplo, mas outros temas não são tão populares, como teoria das emoções ou as teorias sobre o cérebro ou a base material da consciência, num enfoque relacionado com a metodologia proposta pelo autor - ou seja, o enfoque da psicologia histórico-cultural, em sua abordagem materialista e dialética, e diversa de um enfoque comportamentalista do mesmo.

Dessa forma, não considero que esta seja mais uma pesquisa sobre Vigotski, no sentido de explorar novamente caminhos já percorridos, mas que se trata de uma proposta ousada e, por decorrência, arriscada, cujo desafio assumi com o objetivo de contribuir para preencher essa lacuna na leitura da obra vigotskiana, bem como para ampliar o leque de pesquisas sobre a obra do autor - que ainda permanece em boa parte inexplorada.

Como discutirei mais detalhadamente durante o texto, Vigotski, utilizando-se do método materialista histórico-dialético, desenvolveu uma teoria psicológica de fundamentação monista e materialista, sem contudo tornar-se biologicista. Vigotski foi um crítico agudo de Pavlov, cientista renomado e contemporâneo a ele, sendo que ambos desenvolveram suas pesquisas na União Soviética pós-revolucionária. Para Vigotski, agregar conceitos de $O$ Capital a uma proposta de psicologia de base biológica não correspondia à 
necessidade de criar uma psicologia verdadeiramente marxista, que era um objetivo de sua época. Vigotski propõe esta psicologia, que chama de histórico-cultural, baseado no princípio de que a formação do homem se dá em relação dialética constante com o meio social, sendo que as formas superiores de pensamento configuram-se a partir da internalização de relações sociais e de apropriação dos conteúdos culturais acumulados e objetivados pela humanidade.

Vigotski e seus colaboradores desenvolveram várias pesquisas sobre vários temas relacionados à psicologia e também à neurociência. Podem-se destacar as pesquisas de seu colaborador Luria (1902-1977), psicólogo soviético que desenvolveu vasta obra de pesquisa científica, com temas como os problemas fundamentais da concepção histórico-cultural, a organização cerebral das funções psíquicas e o desenvolvimento infantil, entre outros (SHUARE, 1990; OLIVEIRA; REGO, 2010). Luria desenvolveu uma obra fecunda, aliando com esmero o formalismo metodológico do laboratório com a pesquisa não reducionista, procurando uma ruptura com a abordagem da pesquisa psicológica de sua época e que, como apontam Oliveira e Rego, ainda está presente de certa forma nas investigações atuais (OLIVEIRA; REGO, 2010). Luria chefiou uma equipe de cientistas que trabalhou com vítimas de guerra, cuja tarefa consistia em elaborar métodos para diagnosticar comprometimentos devido a lesões cerebrais, bem como a atuar no restabelecimento das funções psíquicas alteradas por tais lesões. Assim, desenvolveu importantes pesquisas no campo da localização de funções cerebrais, e sua teoria dos três unidades funcionais ainda hoje é utilizado como referência em neuropsicologia. A proposta de que as funções psíquicas não se localizam em áreas cerebrais estanques, mas atuam muito mais como uma rede, envolvendo a contribuição de diversas áreas cerebrais de forma sistêmica, foi proposta por Vigotski e desenvolvida por Luria. Porém, como adverte Shuare (1990), Luria destacou-se por pesquisar a partir de um enfoque histórico cultural, onde considerava os processos psíquicos como sendo processos sociais em sua origem, um reflexo do desenvolvimento social e cultural humano, não se limitando a substituir um enfoque mecanicista por outro mais moderno. Além disso, Luria destaca-se por ter realizado um tipo de pesquisa em que o caráter histórico e sistêmico do que está sendo investigado é enfatizado, inclusive pela criação de ferramentas metodológicas para enfrentar a intricada tarefa de estudar a condição humana, como é o caso da exposição das situações clínicas que vai além da mera descrição de dados diagnósticos, o que chamava de "ciência romântica, como destacam Oliveira e Rego (2010). Esta pode ser uma proposição também assumida por essa pesquisa, ou seja: é possível refletir 
acerca das possíveis contribuições da neurociência para a educação não a partir de um enfoque mecanicista, mas sim histórico-cultural?

Leontiev (1903-1979), outro eminente psicólogo do grupo de Vigotski, também enfatizou a preponderância da origem social do psiquismo humano sobre o legado biológico. Desta forma, o indivíduo humano aprende a ser humano apropriando-se do desenvolvimento histórico da sociedade humana (LEONTIEV, 1978). Leontiev aponta que Marx foi o primeiro a fazer uma análise teórica da natureza social do homem e do seu desenvolvimento sócio-histórico:

Todas as suas relações humanas com o mundo, a visão, a audição, o olfato, o gosto, o tato, o pensamento, a contemplação, o sentimento, a vontade, a atividade, o amor, em resumo, todos os órgãos da sua individualidade que, na sua forma, são imediatamente órgãos sociais, são no seu comportamento objetivo ou na sua relação com o objeto a apropriação deste, a apropriação da realidade humana." (MARX, apud LEONTIEV, 1978, p. 267-268, grifos no original).

Leontiev desenvolve essa proposição de Marx utilizando como exemplo o processo de aquisição de um instrumento. Ressalta que o instrumento, enquanto objeto social, incorpora em si as operações históricas de trabalho relacionadas à sua função. Argumenta que os macacos, ao utilizarem uma vara para conseguir apanhar uma fruta, logo a abandonam, e portanto a vara não se torna um suporte permanente dessa função para o macaco, tampouco tal função é transmitida culturalmente. Já no caso do ser humano a relação se inverte, pois é a mão humana que se conforma aos instrumentos criados historicamente através da aprendizagem e da transmissão cultural, e nesse processo, apropria-se das operações motoras envolvidas na criação e no uso desse instrumento pelos homens que o precederam. Leontiev sustenta que o mesmo ocorre com os produtos intelectuais da cultura (LEONTIEV, 1978).

A ideia de uma relação dialética entre corpo biológico e cultura humana, que estaria na base da própria formação biológica a partir da cultura humana, é bastante instigante se tomada à luz das pesquisas neurocientíficas atuais. Pode-se citar como exemplo o experimento dos pesquisadores Hubel e Wiesel, que demonstraram que animais que tinham um olho suturado ao nascer, deixando-se o outro olho livre, apresentavam diferenças entre os as colunas de dominância ocular, sendo que o olho dominante acabava por ocupar maior área cortical (LENT, 2004, p.143-145). O experimento, que demonstra como a plasticidade neuronal ontogenética é influenciada pelo ambiente visual do animal, bem como aborda a questão dos períodos críticos no desenvolvimento de funções, leva-nos a concluir que não 
basta ter um aparato biológico que propicie a visão, mas o animal precisa de um ambiente favorecedor para aprender a ver, e as experiências que vivencia influenciam seu desenvolvimento biológico. No caso do homem, ainda que não se fale em períodos críticos e sim em períodos sensíveis, essas questões adquirem maior complexidade, e foram exploradas por Vigotski ao estudar o desenvolvimento de crianças com deficiências físicas ou sensoriais (VIGOTSKI, 1929).

Um estudo notável e que pode ser relacionado com o tema dessa pesquisa é o desenvolvido pelo neurocientista brasileiro Miguel Nicolelis, na Universidade Duke, nos Estados Unidos. O pesquisador e sua equipe utilizam técnicas de implantação de eletrodos no córtex de primatas a fim de codificar a atividade neuronal, e traduzem essas informações para computadores, que desta forma podem ser utilizadas para movimentar um braço mecânico. Ou seja, esses estudos visam a construção de neurorrobôs que possam ser comandados pelo cérebro do usuário, representando um imenso progresso na construção de próteses. Nesses experimentos, uma macaca com eletrodos implantados em certas áreas corticais relacionadas com o movimento aprende a operar um controle manual tipo joystick, ligado ao computador que registra seus movimentos. Como num videogame, a macaca deve movimentar o cursor e atingir um alvo, com o que recebe um pouco de suco como recompensa. Os sinais cerebrais são filtrados e codificados, e a macaca pode então movimentar o braço mecânico. O mais interessante, e é aqui que faço uma relação com o que Leontiev disse a respeito do uso de ferramentas, é que a macaca continua movimentando o cursor na tela, e recebendo o suco, após a remoção do controle manual, apenas com os sinais cerebrais que são captados pelo dispositivo ligado ao seu córtex (ZACKSENHOUSE et al, 2007). Mais do que isso, os neurônios modulam sua atividade de forma mais intensa quando o controle é ativado pelo cérebro do que manualmente. Isso mostra que a ferramenta e sua utilização foi apropriada pelo cérebro de uma maneira que surpreenderia Leontiev e o próprio Marx, de forma a substituir até mesmo o movimento manual necessário ao aprendizado da movimentação do cursor.

Outro interessante achado da neurociência atual é a pesquisa de neurôniosespelho, desenvolvida inicialmente pelo neurocientista italiano Giacomo Rizzolatti e equipe nos anos 1990, quando demonstraram que alguns neurônios do lobo frontal de macacos que eram ativados durante a realização de uma determinada atividade como pegar um alimento, por exemplo, também eram ativados da mesma forma quando o macaco apenas observava 
outro macaco ou um ser humano realizando a mesma atividade (LAMEIRA et al, 2006, p. 123-124). Um sistema similar também existe nos seres humanos, e as representações das ações no córtex motor é usada tanto para agir quanto para entender as ações do outro e para imitá-lo (RIZZOLATTI et al, 2004). Esse tipo de estudo tem dado margem a pesquisas sobre o papel dos neurônios-espelhos e o autismo (FECTAU et al, 2006; OBERMANA et al, 2005, WILLIAMS et al, 2001). Ora, Vigotski deu atenção especial à atividade de imitação, colocando inclusive esta capacidade na base do seu conceito de zona de desenvolvimento proximal, onde apontava para a importância do que a criança conseguia fazer com auxílio do adulto (VIGOTSKII; LURIA; LEONTIEV, 1992).

Cito esses exemplos para ilustrar algumas provocantes reflexões que podem decorrer deste trabalho. Obviamente, não será possível aprofundá-las aqui, pois é necessário delimitar o escopo desta tese. Diante de tantas possibilidades, fiz a opção de dar um passo atrás, e focalizar os fundamentos da psicologia histórico-cultural. Inicialmente, pensei em pesquisar a obra de Vigotski e Luria, mas logo esta ideia mostrou-se por demais ambiciosa para os limites de uma tese. Durante a reflexão sobre o projeto inicial, compartilhada com a orientadora do trabalho, o objeto foi-se delineando, passando então a enfocar o conceito de cérebro na obra de Vigotski. Colaborou nesta delimitação o fato da obra de Luria ser claramente relacionada à neurociência, uma vez que ele produziu trabalhos bastante específicos no campo, mais exatamente em neuropsicologia. Como apontam Oliveira e Rego (2010), o trabalho de Luria chegou ao Brasil antes do de Vigotski. Seus livros Curso de Psicologia Geral e Fundamentos de Neuropsicologia foram publicados no Brasil em 1979 e 1981 respectivamente, enquanto a versão resumida de Pensamento e linguagem, de Vigotski, foi publicada no Brasil em 1984. Com isso, Luria ficou inicialmente conhecido não no campo da educação, como colaborador de Vigotski, e sim por pesquisadores de ciências biológicas, medicina e fonoaudiologia (OLIVEIRA; REGO, 2010). No entanto, ainda que Luria atribuísse o mérito da criação da neuropsicologia a Vigotski, poucos trabalhos exploram o Vigotski "neurocientista", motivo pelo qual este recorte foi adotado.

Considero, no entanto, que a motivação inicial, relacionada à articulação entre neurociência e educação, não foi perdida - muito pelo contrário, foi adensada e qualificada, e entendo que este trabalho poderá contribuir de forma relevante com as questões que o motivaram em seu esboço inicial. 
Em vista do que foi exposto até aqui, o objetivo desta pesquisa é analisar o conceito de cérebro na obra de Vigotski, discutindo em que medida as proposições teóricas de Vigotski sobre a base material da consciência influenciaram os fundamentos da psicologia histórico-cultural.

Esta tese está organizada da seguinte forma: após esta Introdução, na qual busquei apresentar os interesses que motivaram a pesquisa, seus pressupostos e objetivo, bem como uma breve apresentação de meu percurso acadêmico e profissional, seguem-se os capítulos teóricos.

No segundo capítulo, sob o título Antecedentes históricos da psicologia históricocultural, faço um breve percurso acerca da história da pesquisa do sistema nervoso, a fim de localizar o surgimento deste campo de pesquisa na Rússia pré e pós revolucionária, o que entendo ter exercido forte influência na formação científica de Vigotski e seus contemporâneos. Apresento as figuras de destaque neste panorama, como Sechenov e Pavlov, bem como outros cientistas como Bekhterev, Ukhtomski, Anokhin e Bernstein, todos envolvidos com a pesquisa neurológica. Caracterizo a seguir a psicologia soviética pósrevolucionária, e as tentativas realizadas por alguns pesquisadores destacados de incorporar os princípios materialistas à psicologia, como Basov, Blonski e Kornilov. Uma vez delineado este pano de fundo da pesquisa neurocientífica e psicológica, passo a apresentar o surgimento de Vigotski neste cenário, discorrendo sobre sua biografia e realizando um enfoque particular na questão metodológica, cara a Vigotski, ao apresentar os pressupostos do materialismo histórico-dialético que nortearam sua produção, e cuja aplicação realizada na criação da psicologia histórico-cultural representou uma superação do reducionismo psicológico e do idealismo que caracterizavam as correntes psicológicas da época.

Passo em seguida, no terceiro capítulo, intitulado A pesquisa realizada:objetivos $e$ procedimentos, a apresentar a metodologia utilizada na tese e seu objeto de análise, que compõe-se de vinte textos de autoria de Vigotski produzidos entre 1924 e 1934. Apresento os critérios utilizados para a seleção dos textos, bem como a organização didática que fiz dos mesmos em quatro momentos, denominados cada um por uma palavra ou expressão chave: 1) Reflexo e Consciência (três textos produzidos entre 1924 e 1926); 2) Instrumento (seis textos produzidos entre 1929 e 1930); 3) Funções psicológicas superiores (quatro textos produzidos entre 1924 e 1926); e 4) Cérebro (seis textos produzidos entre 1924 e 1926). 
O quarto capítulo, denominado $O$ conceito de cérebro na obra de Vigotski, traz a análise propriamente dita dos textos selecionados, discutidos sob o enfoque da abordagem de Vigotski à questão do cérebro enquanto base material da consciência.

A discussão da análise realizada é apresentada no quinto capítulo, sob o título Discussão, onde debato as questões emergentes e busco relacionar os apontamentos de Vigotski sobre o cérebro com os fundamentos da psicologia histórico-cultural. Faço também algumas reflexões acerca do estado atual da pesquisa neurocientífica, discutindo alguns pontos convergentes e divergentes em relação à obra de Vigotski.

No sexto capítulo, cujo título é Neurociência e educação sob o enfoque da psicologia histórico-cultural, discuto como a educação tem ensaiado uma aproximação com a neurociência, refletindo sobre os possíveis benefícios e comprometimentos que podem surgir deste encontro, a partir do estado atual dessa discussão no Brasil e no mundo, e levanto algumas possíveis relações da psicologia histórico-cultural com esta temática.

As Considerações finais são apresentadas no sétimo e último capítulo, onde sintetizo o caminho teórico percorrido e aponto desenvolvimentos possíveis a partir do que foi aqui tratado. 


\title{
ANTECEDENTES HISTÓRICOS DA PSICOLOGIA HISTÓRICO-CULTURAL
}

\author{
Em verdade, é impossível entender o funcionamento de qualquer \\ aparelho nervoso sem a pessoa. Isto é cérebro - do homem. \\ [...] Nisto está a essência. \\ $\left(\right.$ Vigotski $i^{3}$
}

\subsection{A neurofisiologia na Rússia pré e pós revolucionária}

A neurofisiologia, ou o estudo das funções e do funcionamento do sistema nervoso, encontrou um grande desenvolvimento na Rússia tanto antes quanto após a Revolução de 1917, sendo um campo particularmente profícuo de pesquisa para Vigotski e seus colaboradores. Nesse sentido, optou-se por fazer aqui um breve histórico do desenvolvimento desta área de pesquisa científica, a fim de traçar um painel do momento em que Vigotski surgirá nesse cenário.

Bennett e Hacker (2005) assinalam que o desenvolvimento inicial do conhecimento no campo da neurofisiologia foi dominado pela questão de saber como se dá a contração muscular envolvida nos movimentos voluntários. As origens deste interesse remontam a Aristóteles (384-322 a.C.), cujas ideias nortearam por séculos a pesquisa da área, passando por Galeno (130-200), que pesquisou como as funções do cérebro, medula espinal e nervos se integram para produzir o resultado motor final, até serem revolucionadas por Descartes no século 16.

\footnotetext{
${ }^{3}$ In: Manuscrito de 1929 (VIGOTSKI, 1929-2004, p.30).
} 
Segundo os autores, os conceitos de fisiologia e de neurofisiologia tiveram origem na época de Vesalius (1514-1564). Fernel (1495-1558) publicou o primeiro tratado formal de fisiologia, onde a define como a investigação dos processos e funções orgânicos, distinguindo-a da anatomia, referente ao estudo morfológico dos órgãos. Isso somente se torna possível após a síntese filosófica de Tomás de Aquino das ideias aristotélicas quando, portanto, já se considera o conceito de alma racional separada do corpo (BENNETT e HACKER, 2005). Fernel observou que alguns atos ocorrem sem intervenção de uma ação diretiva da mente ou intenção, como o movimento das pálpebras ou a respiração. Tais movimentos, que não envolvem volição, podiam, por conseguinte, ser considerados reflexos, assim conceituando-os pela primeira vez.

Com o advento de propostas teóricas como a astronomia de Kepler e a física de Galileu, as explicações teleológicas vigentes até então (baseadas na finalidade das coisas e remontando a Aristóteles) começam a ser substituídas por explicações mecanicistas. Neste período, destaca-se a contribuição de Descartes (1596-1650), que promoveu uma guinada na forma como a neurofisiologia era entendida até então. Para Descartes, a alma não é princípio da vida, mas do pensamento ou consciência. O ser humano é, em essência, um ser pensante, definido pelo que percebe imediatamente em si, e somente ele é o possuidor de uma mente. Descartes postulou a união de mente e corpo como a união de duas substâncias distintas. A propriedade essencial da mente é o pensamento, enquanto que a propriedade essencial do corpo é a extensão. Decorre daí que os movimentos do corpo poderiam ser explicados pela ação da mente sobre ele, através dos atos de vontade, pela ação dos "espíritos animais", uma substância material sutil produzida nos ventrículos do cérebro e conduzida através dos nervos até as células musculares. Descartes traz como contribuição a abertura da atividade animal à analise mecânica, conduzindo ao estudo do que haveria de se tornar a neurociência (BENNETT e HACKER, 2005). Como consequência dessa visão teórica também se fortalece a visão dualista em ciência, ou seja, a distinção entre corpo e mente como dimensões dissociadas.

Posteriormente, Willis (1621-1675) propõe o controle cortical dos movimentos e reflexos, refutando a hipótese da origem ventricular dos mesmos. Stuart (1637-1742) estuda o funcionamento da medula espinal independente do cérebro, fazendo experimentos sistematizados com rãs, em que lhes decepava a cabeça e pressionava a medula para observar o movimento dos membros. Verificou experimentalmente assim que o movimento não tinha 
uma origem mecânica a partir do cérebro, sendo conduzido através das fibras nervosas. A explicação para este fenômeno foi dada por Galvani (1737-1798), através da descoberta da eletricidade animal, onde verificou que os nervos podiam conduzir eletricidade de maneira semelhante a fios metálicos, e que o potencial para produzir eletricidade podia ser encontrado nos próprios nervos (BENNETT e HACKER, 2005).

Contudo, no século 18, a ação reflexa da medula espinal ainda era explicada pela ação da alma, o que persistiu até a demarcação entre função sensorial e motora dos nervos espinais no início do século 19. Bell (1774-1842) identificou as raízes anteriores da medula espinal como motoras, e Magendie (1783-1855) fez o mesmo com as raízes posteriores da medula espinal, nomeando-as como sensoriais - originou-se aí a hipótese Bell-Magendie das raízes espinais. Bell percebeu que a medula espinal não era um simples nervo, mas tinha estrutura semelhante ao cérebro, composta por massa branca e cinzenta. Segundo Bennett e Hacker (2005), como os experimentos envolviam apenas cortes de nervos espinais, Bell e Magendie evitaram as controvérsias sobre se a medula espinal continha uma alma capaz de iniciar o movimento independente do cérebro.

A explicação de como a capacidade de sentir uma sensação se associava à medula espinal foi dada por Hall (1790-1857), que esclareceu o funcionamento da medula espinal como contendo um centro reflexo cuja atuação ocorre de maneira não sensível e independente da vontade, ao contrário dos nervos da sensação (que sobem ao cérebro ou aferentes) e dos nervos motores (que descem do cérebro ou eferentes). Diversamente do que pensava Bell (ou seja, que os atos reflexos precisavam do arco nervoso que vai do músculo ao cérebro e deste ao músculo para se efetivarem - o chamado arco-reflexo ${ }^{4}$ ), Hall propõe que o reflexo precisaria somente de um nervo ligando a parte excitada até a medula espinal, e daí nervos que partissem dela (BENNETT e HACKER, 2005).

Em 1890, Foster (1836-1907) publica uma descrição resumida da relação entre reflexos espinais e cérebro, onde se pode observar que ainda era considerada a ideia de uma

\footnotetext{
${ }^{4} \mathrm{O}$ percurso total percorrido por um impulso nervoso, desde o estímulo desencadeador até a resposta, foi conceituado por Wagner (1805-1864) como arco-reflexo. O arco-reflexo geralmente envolve: 1) um elemento receptor (por exemplo, os órgãos do sentido); 2) um elemento nervoso sensitivo ou aferente, que conduz o estímulo ao centro nervoso; 3 ) um elemento nervoso motor ou eferente, que leva a resposta do centro motor para o efetor, e 4) o efetor, que expressa a resposta (por exemplo, um músculo ou glândula) (KELLER e SCHOENFELD apud SOUZA JUNIOR e CIRINO, 2009, p.160).
} 
alma da medula espinal, indicando que ainda não se concretizara uma abordagem materialista do funcionamento do sistema nervoso.

Enquanto isso, na Rússia, então governada por uma monarquia czarista, durante a segunda metade do século 18 até o início do 20, observa-se o paulatino desenvolvimento de reformas nos campos político, econômico e científico, sob inspiração das tendências advindas da Europa Ocidental. Nesse momento, os pesquisadores russos começam a integrar a comunidade científica da europeia, vivenciando um momento de estreita proximidade e intercâmbio com universidades e clínicas europeias (VEIN, 2007).

As descobertas europeias no campo da neurofisiologia encontraram pronta aceitação entre os cientistas russos, que logo as aplicaram à prática clínica e à formação teórica. A neurologia clínica se torna uma disciplina independente na Rússia já na década de 1860, décadas antes do mesmo ocorrer na Europa (SHTERENSHIS e VAIMAN, 2007). É na Rússia também que se inaugura a primeira clínica para doenças nervosas. No início do século 20, já havia três departamentos independentes de neurologia na Rússia (em Moscou, São Petersburgo e Kazan). Em São Petersburgo foi realizado o primeiro curso de neurologia cirúrgica, e em Moscou foi aberta a primeira clínica de neurologia infantil. Posteriormente, departamentos neurológicos foram estabelecidos em muitos outros lugares, incluindo Kiev, Kharkov, Odessa e Tomsk. Pode-se também verificar o substancial interesse em neurologia e psiquiatria através do número de revistas científicas especializadas publicadas nesta época na Rússia (VEIN, 2007).

Nesse cenário, destaca-se um nome que teria profunda influência no posterior desenvolvimento da neurofisiologia russa: Ivan Mikhailovich Sechenov (1829-1905), cuja contribuição será examinada mais detalhadamente na sequência. 


\title{
2.1.1 Sechenov e a mente enquanto reflexo do ambiente
}

\begin{abstract}
A nova psicologia terá em suas bases, em lugar dos filosóficos murmúrios da voz falaciosa da consciência, em fatos positivos ou pontos de partida que possam ser verificados a qualquer tempo pela experimentação. E somente a fisiologia será capaz de fazê-lo, pois só ela tem a chave da verdadeira análise científica do fenômeno psíquico 5 .
\end{abstract}

(Sechenov)

Sechenov é considerado um dos maiores cientistas russos, tendo proposto originalmente o conceito sobre a determinação sociocultural do comportamento (GRIGORIEV e GRIGORIAN, 2007). Juntamente com Pavlov e Bekterev, Sechenov pode ser considerado um dos mais significativos representantes da chamada escola reflexológica soviética, ou simplesmente reflexologia soviética (SOUZA JUNIOR, 2008).

Sechenov formou-se em medicina na Universidade de Moscou em 1856, após ter estudado também engenharia. Teve a oportunidade de estudar e trabalhar em importantes laboratórios de pesquisa na Europa, particularmente em Viena, sob o comando de Von Helmholtz (1821-1894) e em Berlim, com Muller (1801-1858) e Magnus (1802-1870), bem como em Paris com Bernard (1813-1878) (SOUZA JUNIOR, 2008). Foi considerado por Pavlov como o pai da neurofisiologia russa, tendo declarado que Sechenov marcou de forma decisiva sua carreira científica. Foi influenciado por teóricos como Locke (1632-1704), Darwin (1809-1882) e Spencer (1820-1903), dos quais absorveu elementos das filosofias associacionista e empirista (SOUZA JUNIOR, 2008).

Sechenov propôs o conceito de reflexo como unidade de análise do comportamento humano e animal, não o restringindo ao âmbito da fisiologia do movimento (PESSOTI apud SOUZA JUNIOR, 2008, p.49). Essa abordagem é profundamente inovadora, haja vista que, até o século 19, o estudo da mente humana era atribuição unicamente da filosofia. Na concepção empirista da mente (cujo maior representante é Locke), as ideias se

\footnotetext{
${ }^{5}$ No original: "The new psychology will have as its basis, in place of the philosophizing whispered by the deceitful voice of consciousness, positive facts or points of departure that can be verified at any time by experiment. And its only physiology that will be able to do this, for it alone holds the key to the truly scientific analysis of psychical phenomena" (FROLOV, 1937/2007, p.6).
} 
originam de sensações produzidas por estimulação ambiental, sendo o maior problema dos cientistas desvendar como as sensações simples se associam para produzir ideias complexas. Para Kant (1724-1804), a mente contém algumas ideias a priori (DUROZOI e ROUSSEL, 1993), ou seja, elementos independentes da experiência, como intuições e conceitos, que não podem ser decompostos em elementos mais simples (COLE e SCRIBNER, 1991). Na primeira metade do século 19 fortalece-se uma visão atomista e mecanicista do comportamento humano, que propunha o estudo do comportamento pela decomposição em suas partes constituintes, como as sensações e percepções (FIGUEIREDO, 1991). Aliado ao crescente conhecimento da anatomia dos seres vivos, isso contribui para que o reflexo pudesse ser proposto por Sechenov como a unidade elementar do comportamento, que poderia ser então analisado e conhecido pela identificação de seus elementos constituintes os estímulos e respostas: "o movimento reflexo era - no caso dos movimentos característicos dos seres vivos - o protótipo do movimento automático e mecânico" (FIGUEIREDO, 1991, p.67).

Em 1861, Sechenov formulou pela primeira vez em neurofisiologia a noção de ligação entre o organismo e o meio ambiente, afirmando sua unidade, ideia que reafirmaria constantemente em sua obra. Em 1862, quando trabalhava no laboratório de Bernard, descobriu os reflexos de inibição da medula espinhal pelo sistema nervoso central. Os reflexos simples, de forma geral, envolvem conexões entre neurônios receptores e neurônios efetores através da medula espinal. Contudo, Sechenov expôs que esses reflexos simples eram modificados pela ação do sistema nervoso central, por exemplo, ao se aplicar uma corrente elétrica ou cristais de sais em determinadas regiões do cérebro. Assim, demonstrou experimentalmente que a atividade cerebral está relacionada a correntes elétricas e à composição química do tecido nervoso.

A descoberta de Sechenov da capacidade do sistema nervoso central de controlar respostas externas do organismo, aliada a suas pesquisas sobre o controle dos movimentos, deu origem ao livro Reflexos do cérebro, publicado em 1865. Essa obra é considerada um marco na neurofisiologia russa, sendo reconhecida como uma valiosa contribuição científica. Nela, Sechenov defende que a atividade cerebral é uma atividade reflexa, e que, portanto, a atividade psíquica também pode ser explicada desta forma. Assim, Sechenov expandiu a definição cartesiana de reflexo para o funcionamento do cérebro e da consciência (RAHMANI, 1973). Ele apresenta a tese de que a vida psíquica é uma ação reflexa do 
cérebro, considerando desnecessário e até mesmo danoso postular a ideia da existência da psique de forma independente da matéria. Uma associação de ideias, por exemplo, deveria ser estudada como uma relação entre reflexos (COLE e MALTZMAN, 1969).

Ainda que não possuísse informação suficiente devido aos recursos de pesquisa disponíveis na época sobre a estrutura do cérebro humano, nem que tivesse estudado fenômenos psíquicos em animais, Sechenov afirmava que as "ações psíquicas devem ser compreendidas com base no estudo dos fenômenos psíquicos simples observados em animais e não em seres humanos. [...] Existe alguma relação entre as ações psíquicas e os chamados processos nervosos no corpo que são de natureza puramente somática ${ }^{6 "}$ (SECHENOV apud BERITASHVILI, 1968, p.253), estando convencido da similaridade entre os processos observados por ele no laboratório e o sistema nervoso central humano (COLE e SCRIBNER, 1991). Assim, Sechenov concluiu que as ações psíquicas do tipo reflexo podem ser objeto de pesquisa fisiológica, o que seria demonstrado por Pavlov alguns anos depois. Para Beritashvili (1968, p.262), em Reflexos do cérebro Sechenov demonstrou que "todos os atos da atividade consciente e inconsciente de um ser humano, não importando o quanto sejam complicados, devem-se a sua interação com o mundo externo, sendo portanto reflexos em sua origem ${ }^{7}$ ". De acordo com Frolov (1937), Sechenov entendia o pensamento como um reflexo inibido. Ou seja, considerando-se o arco-reflexo, o pensamento seria um reflexo que perdeu sua última parte, ou a expressão da resposta após a chegada do estímulo no sistema nervoso. Deste modo, para Sechenov, reflexos e atos psíquicos seriam essencialmente idênticos.

A publicação de Reflexos do cérebro deu prestígio a Sechenov entre os intelectuais russos radicais, grupo conhecido como a "intelligentsia", para quem a ciência era uma forma de atacar a ideologia oficial, "fazendo da fisiologia um tópico bastante

\footnotetext{
${ }^{6}$ No original: "psychical actions should be worked out on the basis of the study of simplest psychical phenomena observed in animal and not in human beings [...] there exists some relationship between the psychical actions and the so-called nervous process in the body which are so purely somatic nature".
}

\footnotetext{
${ }^{7}$ No original: "all acts of conscious and unconscious activity of a human bing, no matter how complicated, are due to this interaction with the outside world and therefore are reflex in origin".
} 
significativo de debate na sociedade russa, e de seu autor uma figura de referência na onda liberal e intelectual da década de $1860^{8 \%}$ (KICHIGINA, 2009, p. 225).

Assim como outros cientistas na Rússia czarista, Sechenov viveu em conflito constante com as autoridades, bem como com seus colegas mais conservadores, sendo inclusive processado pelo comitê de censura de São Petesburgo em 1866, dado o caráter materialista de suas propostas. Nesta época, a monarquia à frente do governo russo era marcada por forte inspiração religiosa. Originalmente, Reflexos do cérebro receberia o título "Uma tentativa de estabelecer a base biológica dos processos psíquicos", que foi censurado, pois a ideia de que a psique fosse produto da atividade fisiológica cerebral foi vista como uma afronta à concepção religiosa dos processos psíquicos como algo espiritual e de origem divina (SOUZA JUNIOR, 2008). Sechenov foi então obrigado a mudar o título do livro e publicá-lo em uma revista especializada, e não como um livro de alcance popular, conforme seu desejo inicial (PESSOTI apud SOUZA JUNIOR, 2008).

Apenas após a Revolução de 1917, com o fortalecimento da pesquisa científica de base materialista, é que a obra de Sechenov é retomada e suas propostas incorporadas na reflexão de pesquisadores posteriores. Rahmani (1968) aponta que o legado de Sechenov (bem como o de Pavlov) foi uma pré-condição para o desenvolvimento de uma psicologia de base materialista e determinista, pois ainda que não dispusesse de um método experimental em sua época para embasar o desenvolvimento de uma teoria reflexa da mente, isso não o intimidou, pois considerava imperativo o avanço neste campo.

\subsubsection{A Revolução de 1917 e o fortalecimento da psicologia da atividade nervosa superior}

Como se sabe, a Revolução Russa de 1917 foi o resultado de uma série de eventos políticos ocorridos na Rússia, tendo compreendido duas fases distintas. Inicialmente, em março de 1917, o governo autocrático do czar Nicolau II foi derrubado pelos mencheviques,

\footnotetext{
${ }^{8}$ No original: "made physiology an enormously significant topic of debate in Russian society, and its author a landmark figure in the intellectual and liberal upsurge of the $1860 \mathrm{~s}$ ".
} 
movimento político de caráter liberal, após o que se procurou estabelecer uma república de inspiração liberal, sob responsabilidade de um governo provisório conhecido como Duma. No entanto, as intensas lutas políticas tiveram continuidade, o que culminou na Revolução de Outubro de 1917 (novembro no calendário ocidental), na qual o partido bolchevique, liderado por Lenin (1870-1924), depõe o governo provisório e inicia o governo socialista soviético, processo que resultaria da criação da União das Repúblicas Socialistas Soviéticas, que duraria até 1991.

Conforme já exposto, a tradição russa e posteriormente soviética no campo de pesquisas neurofisiológicas não se iniciou com a Revolução de 1917, mas foi sem dúvida valorizada e consolidada por ela, perfazendo uma das tendências principais no primeiro momento pós-revolucionário. Em relação à psicologia, a concepção neurofisiológica da mente não se colocava como mais um modelo, mas sim como uma proposta de substituição: "O paradigma científico-natural da fisiologia, estendido à compreensão e estudo dos fenômenos psíquicos, foi considerado por muitos investigadores e por muito tempo a base necessária e suficiente para construir uma psicologia materialista" (SHUARE, 1990, p.43). Entretanto, Shuare (1990) assinala que, se por um lado a tentativa de explicar o fenômeno psíquico através do estudo das funções neurofisiológicas cerebrais podia ser visto como um avanço em relação às explicações idealistas e irracionais anteriores, por outro lado fortaleceu uma visão mecanicista e a-histórica da psique humana, fato que viria a ser observado e criticado por Vagner já em 1914, e posteriormente por Vigotski.

$\mathrm{O}$ acirramento dessa visão mecanicista terminou por conduzir a uma divisão da psicologia soviética. De acordo com Cole e Maltzman (1969), podem-se observar duas correntes distintas de pesquisa na psicologia soviética. Uma delas, cujo maior representante seria Pavlov (1849-1936), é a psicofisiologia ou estudo da atividade nervosa superior, que se coloca como um ramo da fisiologia e se aproxima - segundo os autores - mais da psicologia experimental americana do que da psicologia soviética propriamente dita. Esta última é a outra corrente de pesquisa, que se caracteriza pelo não reducionismo a explicações puramente biológicas do fenômeno psíquico, ramo em que se filia o trabalho de Vigotski. Aliás, o

\footnotetext{
${ }^{9}$ No original: "El paradigma científico-natural de La fisiologia, extendido a la comprensión y estudio de los fenômenos psíquicos, fue considerado por muchos investigadores y por mucho tiempo la base necesaria y suficiente para construir uma psicología materialista.
} 
psicólogo bielorrusso, em seu formidável trabalho $O$ significado histórico da crise da psicologia, de 1927, analisa essa tendência não apenas no interior da psicologia soviética, mas na constituição da então incipiente ciência psicológica como um todo (o que será apropriadamente discutido adiante).

Assim como Pavlov (1849-1936), a psicofisiologia era também representada por Bekterev (1857-1927). Esses dois cientistas, que junto com Sechenov formam a tríade da reflexologia soviética, como anteriormente mencionado, também influenciaram o trabalho de Vigotski (SOUZA JUNIOR, 2008), principalmente no início. Outros cientistas que podem ser considerados como tendo realizado contribuições importantes no estudo da então chamada atividade nervosa superior são Ukhtomski (1875-1942), Anokhin (1898-1974) e Bernstein (1896-1966), cujos trabalhos serão brevemente referidos aqui, a título de ilustração da diversidade e fertilidade das pesquisas desenvolvidas neste campo de estudo, bem como na já enunciada compreensão do contexto histórico que engendra o aparecimento da psicologia histórico-cultural.

\subsubsection{Pavlov e a teoria dos reflexos condicionados}

Chegará o tempo, ainda que remoto, em que a análise matemática, baseada na análise cientifica natural, abrangerá em sua fórmula magnífica todo este equilíbrio, incluindo finalmente a vida em si mesma ${ }^{10}$.

(Pavlov)

Pavlov cursou a escola religiosa, mas a intenção inicial de estudar teologia foi logo suplantada pela leitura de Darwin (SHULTZ e SHULTZ, 1992). Ingressou em 1870 na Faculdade de Direito na Universidade São Petersburgo, trocando de curso em seguida para Medicina, não com a intenção de seguir carreira como médico e sim treinar para especializarse em fisiologia animal. Dedicou-se com disciplina rígida à pesquisa, mesmo enfrentando dificuldades econômicas, até assumir o cargo de professor de farmacologia na Academia Médica Militar de São Petersburgo em 1890, onde se tornou chefe da cátedra de fisiologia (de

\footnotetext{
${ }^{10}$ No original: "The time will come, even if it be remote, when mathematical analysis, based on natural scientific analysis, will embrace in its magnificent formulae all these equilibia, including finally also life itself'(FROLOV,1937/2007, p.3 ).
} 
1896 até 1924). Em 1891 assumiu a chefia da Seção de Fisiologia do Instituto de Medicina Experimental, que ajudou a organizar, e a partir de 1925 atuou como diretor do Instituto de Fisiologia da Academia de Ciências da URSS, tendo deixado ambos os cargos apenas por ocasião de sua morte, em 1936 (SHUARE, 1990, p.47).

Durante sua vida, Pavlov dedicou-se basicamente a três temas de pesquisa. Inicialmente, pesquisou a função dos nervos cardíacos. Logo após, dedicou-se a investigar o papel das glândulas digestivas, trabalho que lhe deu reconhecimento mundial e pelo qual recebeu o Prêmio Nobel em 1904, o primeiro concedido a uma pesquisa em neurofisiologia. Por fim, de 1902 até sua morte, pesquisou o que denominava como atividade nervosa superior, a partir do que formulou e utilizou a técnica do condicionamento, considerada sua maior realização científica (SHULTZ e SHULTZ, 1992). Entre as investigações que empreendeu, pode-se citar as leis de desenvolvimento e extinção da resposta reflexa condicionada, a inibição cortical, os diferentes tipos de inibição, o sonho do ponto vista normal e patológico, as neuroses experimentais, a localização das funções no córtex cerebral e os dois sistemas de sinais no estudo da linguagem (SHUARE, 1990).

Pavlov foi influenciado pelo conceito de neurismo (com base nas concepções Sechenov), fonte teórica em que apoiou suas pesquisas. Segundo esta tese, o sistema nervoso exerceria uma função reguladora das funções do organismo, tanto do ponto de vista normal quanto patológico, sublinhando o caráter reflexo da atividade psíquica (SHUARE, 1990). O conceito de neurismo foi proposto por Magendie (1783-1855), cujo trabalho teve forte influência sobre Bernard, um dos professores de Sechenov (SAMOILOV, 2007).

Pavlov é descrito como um homem sem participação política mais ativa, dedicando-se prioritariamente a suas pesquisas e nutrindo sentimentos ambivalentes em relação ao então recém implantado governo socialista soviético. Tendo sofrido dificuldades no período czarista e vivenciado uma situação mais favorável na época pós-revolucionária, quando passa a ser generosamente apoiado em suas pesquisas pelo governo soviético, era de se esperar um maior envolvimento de Pavlov em questões políticas, principalmente no apoio ao regime, mas não parece ter ocorrido desta forma. Schultz e Schultz (1992) apontam que Pavlov era de certa forma crítico ao governo soviético, passando a ter uma opinião mais favorável apenas após 1933, quando reconheceu os progressos obtidos em relação à união dos povos soviéticos. Não se pode afirmar, no entanto, que tal reconhecimento tenha se dado de forma isenta em relação às questões políticas. Meijer e Bruijn (2007) comentam ironicamente 
que, em 1934, Pavlov se "converteu" ao comunismo, após avaliar que Stalin (1878-1953) teria sido menos perigoso para a humanidade do que Hitler, passando a apoiar publicamente o governante soviético. Souza Júnior e Cirino (2009) argumentam que não fica clara a filiação ideológica de Pavlov, e que sua opção por permanecer nos limites do seu laboratório, assentado em uma suposta neutralidade científica, pode ter colaborado para a apropriação ideológica da ciência em detrimento de seus ideais de contribuição para a humanidade, como parecia ser o desejo de Pavlov. Shuare avalia, no entanto, que Pavlov não pode ser individualmente responsabilizado pelo emprego de suas contribuições teóricas como única possibilidade sobre a compreensão do psiquismo humano, considerando que sua teoria "pode ser canonizada e elevada à categoria de 'dogma explicativo' [...] porque esta concepção continha em si mesma os elementos e enfoques que, na época dada, correspondiam plenamente a uma visão peculiar do homem, seu papel e lugar na sociedade ${ }^{11 ”}$ (SHUARE, 1990, p.49).

\subsubsection{Condicionamento e reflexo condicionado}

Schultz e Schultz (1992) assinalam que a noção de reflexo condicionado proposta por Pavlov derivou de uma descoberta acidental. Em sua pesquisa sobre as glândulas digestivas, Pavlov empregava cães como sujeitos. Utilizando um rigoroso método experimental, a saliva dos animais era medida, para o que era necessária a implantação de um dreno coletor, que através de um tubo desviava a saliva para fora da boca do animal, onde era coletada e quantificada, numa operação delicada e engenhosa (SCHULTZ e SCHULTZ, 1992). Até então, sabia-se que a salivação se produz por um arco-reflexo involuntário, disparado quando o alimento entra em contato com a boca do animal e atua como um estímulo nas terminações nervosas bucais. No entanto, Pavlov observou que algumas vezes a saliva era secretada antes do animal colocar o alimento na boca, ao apenas olhar a comida, ou quando ouvia os passos do tratador. Esse tipo de acontecimento era tido como um obstáculo

\footnotetext{
${ }^{11}$ No original: "pudo ser canonizada y elevada a la categoria de "dogma explicativo" (aunque, como se sabe, los dogmas no explican nada) porque em si misma esta concepción contenia los elementos y enfoques que, em la época dada, se correspondian plenamente a uma peculiar visión del hombre, de su papel y lugar em la sociedad.’
} 
pela equipe do laboratório de pesquisas, que buscava formas de neutralizá-lo. Tal fato levou Pavlov a perceber que "o reflexo da secreção, com sua resposta não aprendida da salivação, tinha de alguma maneira se conectado com - ou sido condicionado por - estímulos que, em ocasiões precedentes, estavam associados com o ato de alimentar" (SCHULTZ e SCHULTZ, 1992, p.226). Inicialmente, Pavlov chamou este fenômeno de reflexo psíquico, em contraposição ao reflexo fisiológico, como ele havia denominado as respostas que ocorriam por estimulação direta pelo alimento (SOUZA JUNIOR, 2008). Tentou a princípio buscar uma explicação imaginando os estados subjetivos do animal, caminho que logo se revelou estéril, definindo-se então pela busca objetiva de explicações para o fenômeno que observara (SCHULTZ e SCHULTZ, 1992).

A partir disso, Pavlov idealizou um experimento para observar o reflexo de salivação, que pode ser descrito como segue (SOUZA JUNIOR, 2008, p.58-59):

\begin{abstract}
Numa sala com isolamento térmico, visual e acústico, o sujeito experimental, em geral um cão, era colocado sobre uma mesa e preso por correias para que o conservassem numa mesma posição durante o procedimento. Por meio de uma fístula, aberta na parte inferior do focinho do animal e acoplado a uma das glândulas salivares, partia um tubo emborrachado graduado que desembocava num recipiente, também graduado, fixado sobre uma mola bastante sensível. Esta, por sua vez, possuía uma agulha que registrava o gotejamento da saliva numa peça cilíndrica que girava à velocidade baixa e constante, chamada quimógrafo. Na sua superfície ficavam registrados os momentos exatos em que havia secreção salivar e no recipiente graduado aferia-se precisamente o seu volume. O procedimento clássico consistia, inicialmente, na apresentação de um pedaço de carne a um animal experimentalmente ingênuo e privado de alimento. Logo em seguida, permitia-se que o sujeito experimental o comesse. Com a repetição do procedimento, bastava a visão do alimento para que o animal salivasse abundantemente. Sabia-se que ao mastigar alimento qualquer mamífero secretaria bastante saliva, fato que ficou devidamente registrado no recipiente que continha a saliva secretada no experimento. Contudo, o reflexo salivar mediante a visão do alimento só foi obtido após algumas repetições do procedimento. Este processo demandou uma aprendizagem ou condicionamento, como Pavlov preferiu chamar o fenômeno. A secreção salivar, ocorrida mediante a estimulação bucal exercida pelo alimento, é um tipo de reação orgânica inata. Logo, Pavlov denominou a secreção salivar nestas condições de resposta incondicionada, pois não requeria nenhuma aprendizagem prévia para que ocorresse. Nestas circunstâncias, o alimento na boca do animal foi chamado estímulo incondicionado, que eliciava uma resposta também incondicionada. Por outro lado, a salivação ocorrida após a visão do alimento demandou aprendizagem e, portanto, foi denominada resposta condicionada, eliciada por um estímulo condicionado (neste caso, visão do alimento).
\end{abstract}

Uma ilustração do dispositivo utilizado por Pavlov pode ser vista na Figura 1. A partir destes estudos, o termo reflexo psíquico foi substituído pelo termo reflexo condicionado, contrapondo-se assim ao conceito de reflexo incondicionado, ou seja, o reflexo de resposta fisiológica à estimulação direta dos receptores. São chamados de sinais os 
estímulos que acompanham o aparecimento de uma resposta. Tais estímulos anteriormente eram neutros (por exemplo, a luz ou a campainha), mas deixaram de sê-lo após o processo de condicionamento, onde passam a sinalizar a presença do reflexo anteriormente incondicionado e agora condicionado (a salivação), uma vez que foi pareado com o mesmo ou seja, ocorreu ao mesmo tempo, tendo portanto com ele uma relação de contiguidade (SOUZA JUNIOR, 2008).

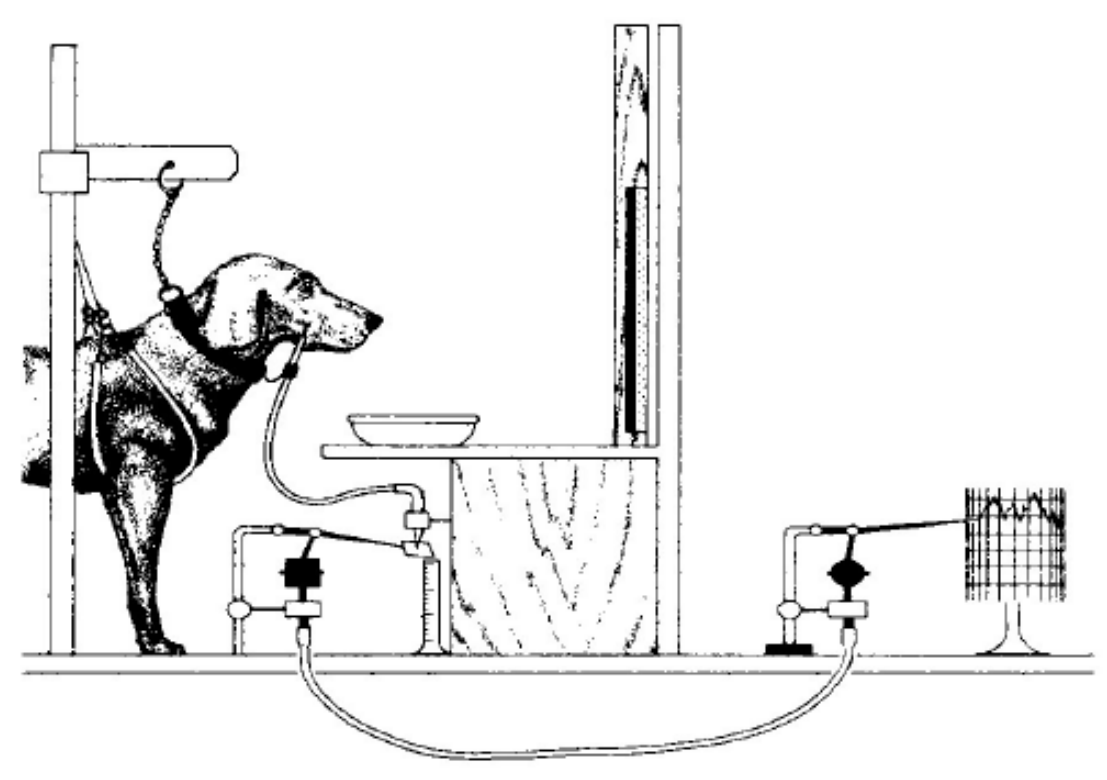

Figura 1: Dispositivo utilizado por Pavlov na pesquisa dos reflexos condicionados (PsyWWW apud SOUZA JUNIOR, 2008, p.59)

Este achado teve um papel revolucionário, uma vez que aborda os limites entre o que era tido como estritamente físico e estritamente psíquico. Pavlov logo percebe que sua descoberta poderia ser extrapolada para uma explicação do comportamento animal e humano, baseada na associação sucessiva de estímulos e reflexos condicionados. Desta forma, "aquilo que fora então denominado como vida psíquica consistiria numa cadeia complexa de excitações e inibições de reflexos no tecido neural, baseadas na programação filogenética e nos condicionamentos ocorridos no decurso da vida dos animais superiores" (SOUZA JUNIOR, 2008, p.60, grifado no original). Para Pavlov, a atividade neural teria uma finalidade adaptativa. Os reflexos condicionados seriam uma forma recente na evolução dos 
processos de adaptação do indivíduo ao meio, sendo o resultado da experiência individual acumulada (SHUARE, 1990). A aprendizagem seria o resultado das variações ambientais, que resultariam na constituição de indivíduos únicos, a partir das relações estabelecidas com seu ambiente (SOUZA JUNIOR, 2008).

As pesquisas de Pavlov exerceram um profundo impacto no cenário científico soviético, sendo consideradas como explicação suficiente e materialista da psique. Alguns anos mais tarde, seriam elevadas ao status de explicação oficial do fenômeno psíquico, sendo rechaçadas as teorias que concebessem o psiquismo humano de outro modo, e levando seus autores aos ostracismo científico e até mesmo à perseguição política, como aconteceu com a própria obra de Vigotski. Passa-se a seguir a comentar a obra de Bekhterev, contemporâneo de Pavlov.

\subsubsection{Bekhterev e a reflexologia}

Trata-se de um cientista de enorme destaque e contribuições diversas para a neurofisiologia mundial. Em suas pesquisas, Bekhterev tentou articular os campos da neurologia, psiquiatria, neurofisiologia, neuroanatomia, neuropsicologia e neurocirurgia, podendo portanto ser considerado o fundador da abordagem multidisciplinar na exploração do cérebro (VEIN, 2007). Pesquisador profícuo, publicou uma expressiva quantidade de trabalhos em vida, onde se destaca uma monografia em sete volumes sobre as funções do cérebro (1903-1907). Entre diversos temas, pesquisou as vias de condução do cérebro e da medula espinal, as bases anatômicas e fisiológicas do equilíbrio e da orientação espacial, o papel do hipocampo na memória e as funções do tálamo ótico, tendo também identificado reflexos, sintomas e síndromes neurológicas. Descreveu mais de dez novas doenças e quinze novos reflexos, alguns dos quais foram batizados com seu nome, além de diversas técnicas de diagnóstico (AKIMENKO, 2007).

Bekhterev concluiu a Academia de Medicina e Cirurgia de São Petesburgo em 1878, após o que estudou em Berlim e Paris com cientistas importantes de sua época, como Wundt (1832-1920), que é considerado o fundador da psicologia enquanto ciência, além de Dubois-Reymond (1818-1896) e Charcot (1825-1893). Em 1884, foi convidado por Delyanov, ministro da educação russo, para comandar o Departamento de Psiquiatria da 
Universidade de Kazan, onde fundou o primeiro laboratório de psicofisiologia russo. Organizou e dirigiu a Sociedade de Neuropatologistas e Psiquiatras de Kazan em 1893, quando também assumiu a chefia do Departamento de Doenças Nervosas e Psíquicas da Academia Militar de Medicina, em São Petersburgo, onde também fundou e dirigiu o Instituto de Psiconeurologia em 1903, assim como o trabalho que se tornaria o Instituto do Cérebro, em 1918 (SHUARE, 1990; AKIMENKO, 2007). Também expressou seu interesse na área dos então conhecidos como estudos pedológicos, ou relativos ao desenvolvimento infantil, fundando o Instituto Psicopedológico em 1907 (SOUZA JUNIOR, 2008). Durante a Primeira Guerra, Bekhterev promoveu a reorganização do Instituto Psiconeurológico em um hospital militar, que contava com a primeira unidade neurocirúrgica da Rússia, e que posteriormente foi reorganizada como o primeiro instituto de neurocirurgia do país. De 1920 até sua morte, Bekhterev foi um deputado do Soviete de Petrogrado, onde participou dos trabalhos do Comitê Permanente da Educação Pública de forma ativa (AKIMENKO, 2007).

Ao mesmo tempo em que considerou a existência do mundo subjetivo como inseparável dos processos materiais que ocorrem no cérebro, que chamou de processo neuropsíquico (caracterizado como um processo composto por dois aspectos, e não por dois processos que ocorrem paralelamente), Bekhterev sustentou a impossibilidade de conhecer o aspecto subjetivo de tal processo, sendo possível apenas a observação das manifestações objetivas do processo neuropsíquico. Desta forma, repudiou a psicologia introspectiva, uma tendência determinante da pesquisa em sua época cuja aplicação experimental foi empreendida por Wundt, e defendeu que tal teoria deveria dar lugar à psicologia objetiva. Dessa forma, os aspectos manifestos do processo neuropsíquico, e que deveriam ser o objeto de investigação da psicologia, são os reflexos. A forma de estudá-los deveria ser a mais objetiva possível, com registro de reações e de estímulos provocadores. Bekhterev utilizou o método dos reflexos condicionados em suas pesquisas, fazendo as primeiras tentativas de empregar a teoria da atividade nervosa superior à neuropatologia e à psiquiatria (SHUARE, 1990).

Em 1921, publicou a monografia Reflexologia coletiva. Para Shuare (1990), o desenvolvimento posterior dos estudos de Bekhterev, que acabam por resultar na teoria da reflexologia, contrariam a tendência progressista que se fazia presente em sua crítica à psicologia introspectiva. Shuare cita, por exemplo, sua intenção de reduzir todos os 
fenômenos da natureza e da sociedade a supostos princípios gerais, ou a interpretação dos fenômenos sociais com base em leis da mecânica, como atração e conservação da energia.

Em relação à existência de uma suposta rivalidade entre Bekhterev e Pavlov, Shuare (1990) pondera que há certa confusão entre o trabalho dos dois cientistas, gerada sob o rótulo comum a ambos de reflexologia. Isso ocorre especialmente pela falta de popularidade da obra de Bekhterev se comparada à de Pavlov, o que pode ser atribuído ao fato de serem contemporâneos, bem como ao pioneirismo de Pavlov na postulação da teoria do condicionamento, de acordo com Souza Junior (2008). Para este autor, as contribuições científicas de Bekhterev estão à altura das de Pavlov por sua importância. Ambos receberam subsídios do governo para realização de suas pesquisas, bem como criticaram a psicologia introspectiva, propondo uma psicologia de base fisiológica como alternativa para a explicação da conduta (SOUZA JUNIOR, 2008). Ainda que haja muitos pontos de encontro entre ambos, algumas diferenças se destacam, principalmente considerando as incursões teóricas de Bekhterev acerca da aplicação da teoria dos reflexos aos fenômenos sociais, que é a base da sua reflexologia, além de ter envolvido um leque muito maior de temas em suas pesquisas do que fez Pavlov. Para Souza Junior (2008), a principal diferença entre ambos reside no tipo de reação reflexa estudado. Bekhterev era psiquiatra antes de fisiologista, buscava a aplicação clínica do condicionamento pavloviano e tinha maior interesse pelos reflexos motores, enquanto Pavlov tinha como foco as respostas glandulares. Bekhterev pretendia propor uma psicologia monista, isenta de paralelismo entre mente e corpo, cujo "objetivo deve ser a compreensão dos processos psíquicos no sentido mais amplo do termo, incluindo as condições biológicas da sua manifestação", não restritos aos organismos e abarcando também a vida das comunidades (BEKHTEREV apud SOUZA JUNIOR, 2008, p.71).

A seguir, são apresentados trabalhos de alguns pesquisadores que, ainda que menos divulgados em relação aos três reflexologistas, também ilustram por sua produção o caráter inovador da pesquisa neurocientífica russo-soviética.

\subsubsection{Ukhtomski e a teoria do dominante}

Ukhtomski (1875-1942) ingressou em 1906 na Universidade de São Petesburgo, onde assumiu a cátedra de Fisiologia Humana e Animal em 1922. Lançou em 1923 o trabalho 
O dominante como princípio de trabalho dos centros nervosos, que apresentou no Congresso de Neuropsicologia de 1924 (o mesmo no qual Vigotski fez sua primeira aparição pública diante da comunidade científica russa). Baseado no trabalho de seu professor Vvdienski sobre o domínio de um centro nervoso sobre outros, bem como nas ideias de Sechenov e Sherrington e em seu próprio trabalho experimental, Ukhtomski formulou a tese de que o dominante seria um dos princípios gerais do funcionamento do sistema nervoso, podendo ser definido como "o foco de excitação no sistema nervoso central que determina temporariamente o caráter da reação de resposta do organismo aos estímulos externos e internos" (SHUARE, 1999, p.50). O centro dominante acumula a excitação de outros centros, proposição que enfatiza o caráter integral da atividade orgânica. Ukhtomski defendia que o princípio do dominante poderia explicar a base fisiológica de fenômenos psíquicos como atenção, alucinação e formação da personalidade.

De acordo com Shuare (1990), destaca-se nesta teoria o conceito de órgão dinâmico ou funcional, onde o dominante seria o órgão da atividade do sistema nervoso central. A concepção de órgão funcional que sustenta o conceito não é a de uma unidade morfologicamente estável, mas qualquer combinação de forças que, em condições estáveis, levam a resultados iguais. De acordo com Leontiev, os órgãos funcionais, ainda que funcionem como os órgãos comuns, seriam formações novas, surgidas no processo de desenvolvimento individual ou ontogenético, constituídas "no curso do domínio, pelo homem, do mundo de objetos e fenômenos criados pela humanidade, ou seja, as criações da cultura

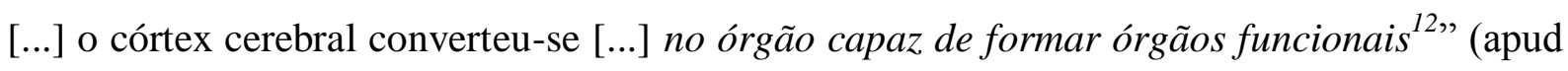
SHUARE, 1990, p.51, grifado no original). A concepção de órgão funcional era inovadora, e apenas anos mais tarde seria desenvolvida por Anokin, em sua teoria do sistema funcional, bem como por Luria, em sua teoria da localização das funções psíquicas, e por Leontiev, no estudo da relação entre cérebro e atividade psíquica (SHUARE, 1990).

\footnotetext{
${ }^{12}$ No original: “... en el curso do dominio, por el hombre, de mundo de objetos y fenómenos creados por la humanidad, o sea las creaciones de la cultura... la corteza del cérebro se convertió... en el órgano capaz de formar órganos funcionales".
} 


\subsubsection{Anokhin e a teoria dos sistemas funcionais}

Anokhin (1898-1974) foi aluno de Pavlov e de Bekhterev, sendo considerado um fisiologista de destaque, e tendo proposto a teoria dos sistemas funcionais. Egiazaryan e Sudakov (2007) defendem que esta teoria esclareceu problemas que permaneceram sem resposta no laboratório de Pavlov, podendo ser considerada uma continuação histórica de suas ideias científicas no estudo da atividade nervosa superior dos seres humanos e animais. Anokhin começou seu trabalho de pesquisa sob a orientação de Bekhterev, mas seu interesse pela pesquisa experimental o levou a trocar a clínica pelo laboratório de Pavlov, onde investigou os reflexos condicionados. Contudo, a abordagem pavloviana não o satisfazia plenamente, pois no seu entendimento os mecanismos cerebrais permaneciam obscuros. Em 1930, por recomendação de Pavlov, foi eleito chefe de Departamento de Fisiologia da Faculdade de Medicina da Universidade de Nizhny Novgorod, onde começa a formatar sua proposição de sistemas funcionais, que definiria como segue (ANOKIN apud EGIAZARYAN e SUDAKOV, 2007, p.196):

Por sistema funcional entendemos uma série de atos fisiológicos definidos relacionados com uma determinada função (ato da respiração, ato da deglutição, ato locomotor, etc.) Cada sistema funcional, sendo de certa forma um sistema fechado, existe devido a uma conexão permanente com os órgãos periféricos e, em particular, com uma aferência permanente desses órgãos. Pensamos que cada sistema funcional tem um complexo definido de sinais aferentes que orienta e corrige a realização dessa função ${ }^{13}$.

Mais tarde, Anokhin classificou os sistemas funcionais como organizações dinâmicas e de auto-reguladas, cujos componentes interagem em harmonia e colaboram na realização de resultados adaptativos, úteis para o sistema em si e para o organismo como um todo. Anokhin enfatizou o papel criativo da aferência proveniente de órgãos periféricos para os centros nervosos, chamando-a de aferência reversa, ideia que seria proposta somente doze anos depois por Norbert Winner no conceito de feedback.

\footnotetext{
${ }^{13}$ No original: "Under functional system we understand a range of definite physiological acts related to a certain function (act of respiration, act of swallowing, locomotor act, etc.). Every functional system, being to a certain extent a closed system, exists due to a permanent connection with peripheral organs and, in particular, with permanent afferentation from these organs. We think that every functional system has a definite complex of afferent signals which directs and corrects the realization of that function".
} 
Em 1950 enfrentou oposições da academia científica soviética, que o acusou de deturpar a teoria de Pavlov. Diante das críticas, Anokin defendeu a ideia de sistema funcional como uma generalização que partia das ideias de Pavlov, mas não foi ouvido, sendo de certa forma exilado em Ryazan, chefiando o Departamento de Fisiologia do Instituto de Medicina, e retornando somente em 1955, com sua eleição para chefe do Departamento de Fisiologia normal do Instituto Médico Legal Sechenov de Moscou. Em seus últimos anos, Anokhin criou uma nova abordagem em fisiologia, a neuroquímica funcional, com o objetivo de investigar os processos químicos do cérebro no desenvolvimento de sistemas funcionais. Seus herdeiros científicos mostraram que o organismo como um todo apresenta uma interação harmônica de uma série de sistemas funcionais em níveis moleculares, homeostáticos, comportamentais e populacionais. Os sistemas funcionais do organismo funcionam pela coordenação de múltiplos parâmetros, o que significa que qualquer mudança de parâmetros em um sistema funcional imediatamente reorganiza o estado de outros sistemas funcionais ligados a ele (EGIAZARYAN e SUDAKOV, 2007).

\subsubsection{Bernstein e o movimento}

Assim como Anokin, Bernstein (1896-1966) foi alvo da perseguição dos cientistas soviéticos no conflito neopavloviano de 1950, sendo acusado de não compreender e depreciar o trabalho de Pavlov e sua importância para a neurofisiologia russa, bem como de confiar muito em trabalhos de autores estrangeiros. Meijer e Bruijn (2007, p.207) relatam que Luria, numa dessas reuniões em 1951, teria dito ironicamente que "no meu trabalho, eu falhei em não colocar meu ponto de partida na teoria de Pavlov da análise do movimento, baseando-me em vez disso sobre as concepções fisiológicas erradas de P. K. Anokhin e N. A. Bernstein [...] 14,. Para os autores, no entanto, tanto os ataques dos neopavlovianos quanto o embasamento de Bernstein no materialismo dialético foram responsáveis pela consistência de seu trabalho científico.

\footnotetext{
${ }^{14}$ No original: "In my work, I failed to take my starting point in Pavlov's theory of the motor analyser, basing myself instead on the wrong physiological conceptions of P.K. Anokhin and N.A. Bernstein..."....
} 
Bernstein estudou medicina, tendo atuado como médico após a revolução, praticado neuropsicologia em Moscou e estudado matemática e música, até ser chamado para integrar o Instituto Central do Trabalho em 1922. Na década de 1920, Bernstein trabalha no laboratório de Psicologia Experimental de Kornilov, juntamente com Luria e Vigotski. Interessou-se pelo estudo do movimento, entendendo que este funcionava como um espelho para ver o funcionamento do cérebro. $\mathrm{O}$ estudo do movimento apresentava alguns obstáculos de difícil transposição para os pesquisadores, como sua rapidez excessiva para o olho humano, permitindo seu estudo apenas após o desenvolvimento da tecnologia da filmagem. Além disso, o estudo das imagens registradas precisa se apoiar em fundamentos matemáticos para que se possa compreender de fato como o movimento ocorre, e Bernstein levaria anos para entrar em contato com este tipo de análise (MEIJER e BRUIJN, 2007).

Desde 1500, a concepção sobre o trabalho do aparelho locomotor era do seu funcionamento como um autômato, produzindo o movimento necessário com a precisão de um relógio. Contudo, o controle dos movimentos não pode ser atribuído simplesmente ao aparelho, levando os cientistas a recorrerem a explicações metafísicas como a alma ou a vontade, como já examinado brevemente neste trabalho. Meijer e Bruijn (2007, p.210) afirmam que o "dualismo e a crença que o sistema locomotor é um sistema mecânico perfeitamente previsível são dois lados da mesma moeda ${ }^{15}$. Inicialmente, Bernstein partilhou da visão dualista sobre o movimento enfatizando o aspecto da automação mecânica, mas logo abandonaria esta concepção, passando a defender que nenhum movimento pode ser completamente planejado desde o seu início, que é necessária uma correção contínua, e que o cérebro exerce este papel organizador. Este novo ponto de vista era mais dinâmico e mais coerente com os pressupostos do materialismo dialético (MEIJER e BRUIJN, 2007).

Desta forma, Bernstein termina se distanciando paulatinamente do ponto de vista pavloviano sobre o assunto. Para Pavlov, o córtex era uma espécie de caleidoscópio de células conectando entradas e saídas, mas uma vez que se conhecesse a entrada, a saída poderia ser determinada. Bernstein discordava, pois observara que a estrutura global do movimento permanece a mesma, enquanto os pormenores nunca se repetem de forma exata. Publica em

\footnotetext{
${ }^{15}$ No original: "Dualism and the belief that the locomotor system is a perfectly predictable mechanical system are two sides of the same coin".
} 
1935 um artigo criticando Pavlov e propondo a noção de coordenação do movimento que lhe daria fama mundial, com péssima repercussão política na comunidade científica soviética. Com o acirramento das perseguições políticas promovidas por Stalin e com a morte de Pavlov em 1936, ele decide cancelar a publicação do livro sobre o assunto.

Nessa época, o conceito de estocasticidade começa a ocupar um lugar importante em sua compreensão acerca da organização do cérebro. Segundo este conceito, o cérebro percebe distâncias e integra informações, permitindo um controle preciso do movimento pelo sistema locomotor, que ocorre no entanto através de comandos cegos, explicados por Meijer e Bruijn (2007) através da analogia com um general que ordena a seus soldados invadirem uma determinada colina, mas não lhes diz exatamente como fazer isso. Bernstein aponta que a regulação real no sistema nervoso reside na parte inferior ou em seus níveis mais velhos do ponto de vista filogenético, sendo de natureza mais química do que elétrica. A regulação nos níveis mais elevados (neocorticais) ocorre de forma estocástica. A ideia de que é nos níveis inferiores que se asseguram as funções biológicas era um pensamento contrário à visão dominante na neurociência da época, mas trata-se da maneira lógica através da qual o cérebro pode ter evoluído. Meijer e Bruijn (2007) apontam que, com isso, "o cérebro de Bernstein pertence à biologia ${ }^{16,}$, sendo tema de seu livro Sobre a construção dos Movimentos, de 1947, que o fez famoso e que precipitou sua queda, segundo os autores. Também estudou a destreza de movimentos, conceito que explicava o fato dos animais serem diferentes de seus antecessores. Quanto mais células corticais uma espécie tem, menos estereotipado é o seu comportamento, e assim ocorre a aprendizagem. Ele argumentaria que os organismos biológicos são ativos, ou seja, agem de acordo com seu ambiente usando um modelo estocástico do passado-presente para prever possíveis resultados da ação. Contudo, a publicação deste trabalho foi proibida em 1950, e Bernstein foi demitido, voltando a trabalhar no Instituto de Física Biológica de Moscou após a morte de Stalin, numa fase de pesquisa mais teórica e em colaboração com matemáticos (MEIJER e BRUIJN, 2007).

Das primeiras hipóteses aristotélicas sobre o movimento até as ainda hoje atuais proposições de Bernstein, o estudo do funcionamento do sistema nervoso fez um grande percurso, para o qual os cientistas russos muito contribuíram. Particularmente, esta

\footnotetext{
${ }^{16}$ No original: "Bernstein's brain belongs to biology".
} 
contribuição afetou de forma importante o nascimento da psicologia soviética, marcado fortemente também pelo clima que se instalou na Rússia após a revolução de 1917.

\subsubsection{A psicologia soviética após a revolução de 1917: Basov, Blonski e Kornilov}

A revolução de 1917 gerou um processo de intensa transformação na sociedade russa e posteriormente soviética, criando um clima favorável para o desabrochar de movimentos artísticos e literários, bem como da psicologia soviética. A psicologia obteve uma atenção especial do novo governo, com apoio às pesquisas científicas. Isso se deveu, segundo Shuare (1990), ao fato da revolução ter provocado uma mudança objetiva na situação da psicologia enquanto ciência, uma vez que as conquistas das pesquisas psicológicas eram consideradas como contribuições importantes para a concretização dos ideais socialistas de construção de uma nova sociedade e de uma nova humanidade. Assim, a psicologia é provocada a sair do lugar tradicional de ciência acadêmica e da suposta neutralidade científica dos laboratórios para produzir conhecimento que possa ser aplicado em situações reais, voltado a dar soluções para problemas concretos desta nova sociedade. Isso, naturalmente, acaba por intensificar os debates já existentes entre a comunidade científica, uma vez que as diferentes tendências passam a disputar a primazia de responder a esta demanda social, através da proposição de uma psicologia embasada nos princípios marxistas. Desta forma, as polêmicas nos campos da natureza do fenômeno psíquico, bem como a definição do objeto da psicologia e seus métodos, passam a ser mote de grandes embates e enfrentamentos, na busca da construção de uma psicologia com status de ciência, cujos princípios metodológicos deveriam naturalmente derivar dos postulados do materialismo histórico e dialético (SHUARE, 1990).

O quadro a seguir, baseado em Shuare (1990), sintetiza as principais características da psicologia no período pós-revolucionário, bem como as consequências advindas de cada uma delas: 
Quadro 1: Psicologia soviética no período pós-revolucionário (SHUARE, 1990)

\begin{tabular}{|l|l|}
\hline \multicolumn{1}{|c|}{ Característica } & \multicolumn{1}{c|}{ Consequências } \\
\hline $\begin{array}{l}\text { Defesa da psicologia tradicional, de caráter } \\
\text { subjetivista e empirista, na linha } \\
\text { experimental. }\end{array}$ & $\begin{array}{l}\text { Aparição de um "novo" objeto de estudo, o } \\
\text { comportamento (contudo, diferente do } \\
\text { behaviorismo americano). }\end{array}$ \\
\hline $\begin{array}{l}\text { Fortalecimento e continuidade da tradição } \\
\text { científico-natural da fisiologia. Objetivo de } \\
\text { não ser apenas um modelo para a psicologia, } \\
\text { mas substituí-la. }\end{array}$ & $\begin{array}{l}\text { A pretensão de reduzir o psíquico à } \\
\text { manifestação subjetiva dos processos } \\
\text { nervosos, sob explicações materialistas } \\
\text { reducionistas. }\end{array}$ \\
\hline $\begin{array}{l}\text { As tentativas de criar um nova abordagem } \\
\text { psicológica baseada no marxismo. }\end{array}$ & $\begin{array}{l}\text { Diferentes propostas que pretendem } \\
\text { incorporar postulados do marxismo na } \\
\text { psicologia. }\end{array}$ \\
\hline
\end{tabular}

Este panorama pode ser ainda caracterizado através do estudo das produções de três psicólogos soviéticos cujo trabalho marcou e foi marcado por esta tendência, e que imediatamente antecedem o surgimento de Vigotski: Basov, Blonski e Kornilov, que são apresentadas na sequência.

Basov (1892-1931) trabalhava no Instituto de Psiconeurologia (fundado por Bekhterev), focando o estudo dos tipos de atividade motora voluntária. Seu objetivo era superar as concepções subjetivistas e empiristas em psicologia, particularmente o associacionismo em voga na época. Colocou o problema das relações entre fatores externos e internos no funcionamento dos processos psíquicos, retomando de Lazurski o conceito de adaptação ativa do homem ao meio, cuja particularidade está no fato de que ele não apenas se adapta ao meio mas adapta o meio a si, transformando-o pelo trabalho e uso de instrumentos. Considerava como objeto de estudo da psicologia a atividade humana, e o homem como ser ativo em seu ambiente. Ainda que o problema da interação do organismo com o meio já houvesse sido anteriormente proposto, Basov foi o primeiro a tomá-lo como um princípio do processo de comportamento. Em relação ao problema psicofísico, defendia a concepção materialista monista, com unidade mas não identidade entre psique e corpo. Trata-se de uma solução dualista e não dialética, como aponta Shuare (1990). O elemento principal da atividade humana para Basov são os reflexos condicionados, ainda que os compreendesse de forma diferente do behaviorismo americano, entendendo que o estímulo modifica o 
comportamento ou a relação da pessoa com o meio. Preocupou-se com os métodos em psicologia, defendendo o uso do método genético no estudo dos fenômenos psíquicos, ligado a ideia de desenvolvimento humano, que segundo ele diferencia-se em duas direções: o desenvolvimento biológico do organismo e o desenvolvimento psicológico do indivíduo enquanto ser social. Atribui à herança e aos fatores biológicos o papel de limitar as possibilidades do desenvolvimento. Como defensor da pedologia, sua obra ficou esquecida por muito tempo a partir da década de 1930, quando essa abordagem do desenvolvimento infantil passou a ser criticada e foi banida pelo governo soviético.

Blonski (1884-1941) atuou como professor universitário de pedagogia e psicologia desde 1913 e investigou a questão do ensino, em que concluiu pela importância decisiva da relação entre teoria e prática educativa para o desenvolvimento da pedagogia enquanto ciência. Neste sentido, publicou em 1920 um estudo polêmico, onde faz uma crítica à psicologia e define seu objeto e método. Para ele, a psicologia deveria ser entendida como uma ciência biológica, cujo objeto é o comportamento humano socialmente influenciado. Foi o primeiro a formular a ideia de que a psicologia científica deve se orientar pelo marxismo, que foi desenvolvida posteriormente por Kornilov, mas o fez de forma reducionista, considerando a existência dos fenômenos psíquicos apenas subordinada as fatores biológicos e sociais. Propôs o conceito de interesse de classe como uma categoria da psicologia, o que é apontado por Shuare (1990) como uma compreensão simplista do que seria uma fundamentação materialista em psicologia, relegando ao homem o papel de submissão passiva às influências do meio e a simples justaposição de conceitos, ou seja, a psicologia enquanto ciência biológica e também social. O mesmo reducionismo pode ser visto na forma como propôs o estudo do comportamento humano do ponto de vista histórico e genético, já que defendia o estudo de organismos inferiores para a compreensão dos organismos mais complexos, o que é uma inversão simples de um dos postulados básicos do marxismo. Shuare (1990) aponta, no entanto, a influência de algumas proposições de Blonski na obra de Vigotski, como o caráter social da psicologia, ainda que Vigotski tenha proposto a divisão da psicologia em individual e coletiva (social), o que Blonski entendia ser um equívoco. Além disso, no trabalho de análise que faz da crise na psicologia (VIGOTSKI, 1927/2004), Vigotski refere-se constantemente ao problema do método em psicologia, o que foi pauta de reflexão para Blonski, bem como a divisão da psicologia em ciência teórica e aplicada. 
Kornilov (1879-1957) dirigiu o Instituto de Psicologia de Moscou nos períodos de 1923-1930 e 1938-1941, e desde 1943 foi membro da Academia de Ciências Pedagógicas da URSS. Em 1921, a escola de Tchelpanov (1862-1936), filósofo e psicólogo idealista e crítico do materialismo (LEVITIN, 1982-2010), da qual tanto Kornilov quanto Blonski foram integrantes, sofre uma ruptura interna, e ambos publicam textos críticos à concepção idealista de psicologia de seu antigo mestre. Kornilov defende a completa separação entre a filosofia e a psicologia - contudo, como adverte Shuare, a recusa da abordagem filosófica em uma teoria não significa que não haja uma sustentação filosófica tácita da mesma, o que, no caso de Kornilov, pode ser caracterizado pela concepção de um materialismo mecanicista na compreensão do fenômeno psíquico. No primeiro Congresso de Neuropsicologia da Rússia, em 1923, Kornilov apresenta um programa de reformulação da psicologia soviética a partir do marxismo (que é um sistema filosófico), defendendo-o como uma superação do dualismo mente/corpo, e definindo a psique como uma propriedade da matéria altamente organizada, superando a princípio o enfoque reducionista. Contudo, assim como Blonski, na tentativa de aplicar os princípios do materialismo histórico e dialético à psicologia, acaba reduzindo o problema da essência social do homem à psicologia das classes sociais. Blonski convida jovens pesquisadores a integrar o Instituto de Psicologia de Moscou - entre eles, Vigotski, Luria e Leontiev. Deve-se reconhecer-lhe o mérito pela recusa a negar a existência da consciência e da psique, ou a reduzi-los a meros processos fisiológicos, também assinalando que a unidade entre eles não significa identidade. Defendeu a tese de que a psique é o reflexo da realidade objetiva, um reflexo especular e não passivo, existindo de forma independente da consciência. Shuare (1990) considera que, se Kornilov inovou em relação à psicologia da época, suas propostas não tiveram consistência para a formulação de uma psicologia marxista. Isso pode ser notado quando afirmou que a psicologia dialética deveria ser a síntese da psicologia empírica de caráter idealista com a psicologia objetiva de caráter reducionista, desconsiderando que justapor duas propostas equivocadas não resultaria numa síntese, mas que ambas deveriam ser superadas dialeticamente. Tal tipo de erro foi apontado posteriormente por Vigotski como a deformação dos conceitos marxistas, evidenciada por uma compreensão superficial dos postulados do materialismo histórico e dialético (SHUARE, 1990). Para Kornilov, o objeto da psicologia é o estudo das reações, que entendia serem a síntese dos aspectos objetivos e subjetivos, propondo a chamada reatologia. Tal concepção fazia uma apropriação ingênua das leis da dialética para a psique, e foi criticada de forma 
contundente por Vigotski (VIGOTSKI, 1927/2004). Contudo, Kornilov destacou a especificidade do psiquismo humano, bem como sua irredutibilidade às leis fisiológicas, físicas ou químicas, graças a sua essência social, conquistada através do trabalho, o responsável por mudanças essenciais na estrutura orgânica e pelos vínculos sociais (SHUARE, 1990).

A partir desse resumo das produções teóricas de Basov, Blonski e Kornilov aqui enfocadas, pode-se concluir que as primeiras tentativas de fundamentar a psicologia no materialismo histórico-dialético de base marxista foram caracterizadas pelo ecletismo e pela superposição de conceitos.

O percurso exploratório desenvolvido até aqui teve como objetivo reconstruir o contexto histórico e filosófico que configura o aparecimento de Vigotski no cenário científico soviético, bem como as ideias circulantes a respeito da relação entre mente e corpo, e as tentativas de realizar uma síntese entre esses aspectos. No que se refere aos objetivos frustrados de construção de uma psicologia marxista, ou elaborados de forma equivocada, observa-se que tal situação sofreria uma guinada com o surgimento de Vigotski, que será enfocado no próximo item.

\subsection{Vigotski e o advento da psicologia histórico-cultural}

Em 1923 e 1924 ocorreram em Moscou e São Petesburgo, respectivamente, os chamados Congressos de Psiconeurologia de toda a Rússia. De acordo com Shuare (1994), tais encontros tinham o objetivo de congregar pesquisadores na área de psiconeurologia (denominação genérica que englobava a psicologia geral, infantil, pedagógica, psicotécnica, psicofisiologia, neurologia e psiquiatria entre outras disciplinas), cujo desafio na época era contribuir para a construção de uma psicologia de base materialista, que apoiasse e subsidiasse o surgimento do novo homem soviético, ideal condizente com os projetos sociais pós-revolucionários.

Como se pôde observar, conviviam no cenário científico diversas correntes teóricas em psicologia, muitas delas conflitantes: Bechterev e a reflexologia, Pavlov e o condicionamento operante, as propostas iniciais de aplicação da filosofia marxista à 
psicologia por Kornilov através da reatologia, e a então decadente concepção funcionalista e idealista de Tchelpanov, para citar as mais influentes.

Boa parte destas linhas teóricas buscava ajustar-se aos princípios do governo soviético, procurando incorporar a filosofia marxista a seus pressupostos teóricos. Contudo, como seria apontado de forma incisiva por Vigotski, tais tentativas não conseguiam ir além de uma mera justaposição de ideias incoerentes pautadas por uma fragilidade metodológica, que acabavam por revelar sua inconsistência em face de uma análise mais aprofundada.

Entre tais correntes teóricas, a que gozava de maior reputação era a de Pavlov, apontada então como a que melhor refletia o que seria a adoção de princípios materialistas em psicologia. Contudo, a psicologia de Pavlov tinha que se haver com algo paradoxal: o fenômeno psíquico, ou seja, a consciência, pensamento ou mente, não era abordado de forma objetiva. A psicologia europeia da época caracterizava-se por tentativas recentes de conhecer a consciência através de sua decomposição em elementos básicos (como a sensação e os sentimentos), o que propuseram Wundt e Titchener, para quem a psicologia tinha como foco a experiência imediata. A metodologia utilizada para tal finalidade era a introspecção ou exame do próprio estado mental, implementada por Tchelpanov na Rússia, que em 1912 fundou o Instituto de Psicologia da Universidade de Moscou. Em seu livro Cérebro e alma (1912), Tchelpanov argumentava que era inútil tentar encontrar uma explicação materialista para a psique, corroborando o paralelismo psicofísico proposto por Wundt, ou seja, a dualidade mente-corpo. $\mathrm{Na}$ era pós-revolucionária, contudo, tal abordagem tornou-se alvo de duras críticas por suas características idealistas e, portanto, anti-materialistas. A investigação da consciência, então, passa a ser identificada com a abordagem introspectiva (SHULTZ e SHULTZ, 1992; VAN DER VEER, 2007; DELARI JUNIOR, 2010).

Tal estado de coisas acaba ocasionando a demissão de Tchelpanov em 1923, sendo sucedido no cargo de diretor do Instituto de Psicologia da Universidade de Moscou por seu aluno Kornilov, cuja proposta de psicologia marxista encontrava boa acolhida, e que pouco tempo atrás criticara duramente seu antigo professor na comunicação intitulada Psicologia contemporânea e Marxismo, proferida também em 1923, por ocasião do primeiro congresso. Posteriormente, em 1926, Tchelpanov criticaria abertamente o enfoque materialista em psicologia no seu trabalho Psicologia ou reflexologia, onde rebate as críticas de Kornilov (SHUARE, 1994; VAN DER VEER, 2007; DELARI JUNIOR, 2010). Desta forma, no cenário que então se configurava, a consciência como objeto de estudo da 
psicologia era inviável, devendo o pesquisador ater-se às manifestações fisiológicas do psiquismo de maneira científica e experimental, ou seja, através do estudo da atividade reflexa, o que se supunha estar de acordo com a aplicação à psicologia de uma determinada interpretação da filosofia marxista.

Consequentemente, o problema principal que se colocava nesse contexto era a definição do objeto de estudo da psicologia (Shuare, 1994, p.53), podendo ser colocado nos seguintes termos:

[...] em primeiro lugar, a aplicação criativa da dialética como método de investigação; em segundo lugar, a superação da ruptura, posteriormente acirrada, entre a definição da psique como produto da matéria altamente organizada, como função do cérebro, e a natureza social da consciência e da personalidade humanas ${ }^{17}$.

Foi nesse cenário que, em janeiro de 1924, subiu à tribuna do Segundo Congresso de Psiconeurologia um jovem professor de psicologia vindo de Gomel, cidade próxima a Moscou. O palestrante, então com 27 anos, era desconhecido para a maioria da plateia, não sendo afiliado a nenhum dos grupos ali representados. O título da sua palestra era $O$ método de investigação reflexológica e psicológica ${ }^{18}$. Nesta apresentação, o palestrante apontou o idealismo e dualismo presentes na reflexologia de Bekterev e Pavlov quando propõe a separação entre psique e comportamento humano, bem como defendeu que a psicologia não poderia abandonar a consciência como seu objeto de estudo, sendo este seu foco por excelência. Ele afirmou: "estudar o comportamento da pessoa sem a psique, como quer a reflexologia, é tão impossível como estudar a psique sem o comportamento. Não é possível, portanto, abrir espaço para duas ciências distintas" (VIGOTSKI, 1924-1926/2004, p.26).

Esse jovem professor era Lev Semionovitch Vigotski. Segundo o relato de sua filha, Guita L. Vygodskaia, seu discurso teria causado uma vívida impressão na plateia ali presente. Relata-se que Luria, que até então não o conhecia, ao aproximar-se para apresentarse e conversar com o autor de ideias tão provocantes, notou-lhe nas mãos apenas uma folha de papel em branco. A surpresa e admiração de Luria foram maiores do que a já causada pela

\footnotetext{
${ }^{17}$ No original: [...] en primer lugar, la aplicación creativa de la dialéctica como método de investigación; en segundo lugar, la superación de la ruptura, posteriormente, agudizada, entre la definición de la psiquis como producto de la materia altamente organizada, como función del cerebro y la naturaleza social de la consciencia y de la personalidad humana.

${ }^{18}$ Segundo Van der Veer e Valsiner (2001), esta foi uma das três apresentações realizadas por Vigotski no segundo congresso, não havendo registro das outras duas, que aparentemente versavam sobre sua experiência docente.
} 
fala clara, segura e provocativa do palestrante, diante de uma plateia tão qualificada, ainda que fosse esta sua primeira apresentação num congresso desse porte (VYGODSKAIA, LIFANOVA, 1999). Na mesma ocasião, Vigotski é convidado por Kornilov para integrar sua equipe de trabalho no Instituto de Psicologia da Universidade de Moscou, onde teria um contato profissional mais efetivo com seus futuros colaboradores mais conhecidos, Aleksandr Romanovitch Luria (1902-1977) e Aleksei Nikolaevitch Leontiev (1903-1979), cuja parceria de trabalho ficaria conhecida como a Troika (grupo de três). Tal convite é prontamente aceito por ele, que logo se muda com sua família para Moscou.

O relato acima abriga traços um tanto fabulosos sobre o aparecimento de Vigotski no cenário da psicologia soviética, pois é bastante provável que não se tratasse de uma mera aparição, e sim talvez até de um convite para participar do congresso, uma vez que Vigotski não era completamente desconhecido em Moscou, tendo lá vivido e estudado por quatro anos. Além disso, Vigotski tinha uma atuação no cenário cultural de sua cidade, publicando artigos em diversos periódicos e jornais, e também montado um laboratório de psicologia (VAN DER VEER, VALSINER, 2001). Nem por isso sua fala pode ser considerada menos inovadora ou provocativa, ou ainda tendo causado menos impacto na plateia presente.

Mas quem foi Vigotski?

Nascido em uma família judia de formação intelectual e boas condições financeiras em 1896, na cidade de Orsha (localizada próximo à capital Minsk, na Bielorrússia, região então dominada pela Rússia), recebeu seus primeiros estudos em casa, e posteriormente, em uma escola particular judaica na cidade de Gomel. Ainda adolescente, demonstrou interesse por literatura e arte. $O$ fato de ser judeu influenciou sua formação acadêmica, uma vez que os judeus russos na época tinham uma cota reduzida para ingresso na universidade. Como aos judeus não era permitido empregar-se como funcionários públicos, a carreira do magistério poderia apenas ser exercida em escolas particulares judaicas, tornandoa portanto limitada e pouco atrativa. Vigotski oscilou entre a Medicina e o Direito na Universidade de Moscou, optando pela primeira mas logo a abandonando e ingressando na segunda, também se graduando em História e Filosofia na Universidade do Povo de Shanjavsky. Ao concluir seus estudos, em 1917, retorna a Gomel. Com a revolução, obteve permissão para lecionar em escolas estaduais, onde ensinou, entre outros temas, literatura, psicologia e pedagogia. Publicou vários artigos e resenhas literárias, tendo participado ativamente da vida cultural da cidade. Nesse período, desenvolve-se e consolida-se seu 
interesse por psicologia e educação, sugerindo que ele não era exatamente um novato na área quando da sua palestra inicial em Moscou, em 1924. Sua obra Psicologia pedagógica foi publicada em 1926, e trata-se de um manual no qual sistematiza o conteúdo de suas aulas de psicologia para professores, de conteúdo abrangente e provavelmente escrito por volta de 1924, o que também indica que Vigotski não era um autor inexperiente ao apresentar-se no Segundo Congresso de Psiconeurologia (VAN DER VEER, VALSINER, 2001).

Sob a direção de Kornilov, a orientação científica dada às pesquisas do instituto girava em torno da reatologia, ou estudo das reações. O conceito de reação de Kornilov abarcava o estudo da reação como um processo dinâmico que envolvia a ação recíproca entre organismo e ambiente, associado ao conceito de energia psíquica (VAN DER VEER, VALSINER, 2001), e que seria a síntese dos aspectos objetivos e subjetivos (SHUARE, 1990). Ainda que Vigotski avaliasse que a apropriação dos conceitos marxistas feita por Kornilov era de certa forma superficial e não dialética na medida em que apenas aglutinava conceitos contraditórios (VIGOTSKI, 1927/2004), é preciso reconhecer que Kornilov foi quem primeiro propôs o uso da dialética como método de investigação em psicologia, além de atribuir um papel fundamental ao estudo do psiquismo humano e sua essência social, bem como a interdependência entre os processos mentais e fisiológicos (SHUARE, 1990).

Contudo, na época Vigotski empregava uma orientação teórica semelhante a Kornilov (VAN DER VEER, VALSINER, 2001; ALMEIDA, 2008), o que provavelmente foi decisivo para admiti-lo na equipe. Isso pode ser notado no uso da terminologia específica desta abordagem em suas produções da época (como a pesquisa sobre a reação estética a textos literários, que mais tarde resultariam na sua tese de doutorado sobre psicologia da arte acerca de Hamlet, de Shakespeare). A equipe de Kornilov pesquisava uma grande variedade de temas, dividindo-se em seis seções: psicologia geral e experimental, psicologia social, psicologia aplicada, psicopatologia, psicologia infantil e comportamento animal. A ambição de unificação de estudos variados sob a chancela de uma psicologia marxista era, no entanto, bastante incipiente, abrigando diversas orientações teóricas. Kornilov, por exemplo, não considerava a reatologia incompatível com a psicanálise, admitindo que o processo psicanalítico pudesse levar ao equilíbrio dialético do gasto energético entre as esferas mental e corporal (VAN DER VEER, VALSINER, 2001), motivo pelo qual alguns integrantes de sua equipe realizavam estudos na área, entre os quais se incluía Luria. Vigotski publica em 1926 um artigo baseado em sua comunicação no Segundo Congresso de Psiconeurologia de 1924 
(VIGOTSKI, 1924-1926/2004), no qual fica explícita sua aceitação da reatologia. Sua aproximação, bem como de Kornilov, com as ideias dos psicólogos da Gestalt, também foi uma busca de superação do reducionismo apontado nos trabalhos de Pavlov e Bekterev. Vigotski, aliás, manteve intenso diálogo com as pesquisas dos gestaltistas como Max Wertheimer (1880-1943), Wolfgang Köhler (1887-1967) e Kurt Koffka (1886-1940) durante toda sua obra, tanto para ratificar quanto para refutar e criticar suas proposições. Sob a orientação de Kornilov no instituto, participou de experimentos sobre a interdependência de reações, recorrendo ao "princípio do dominante" de Ujtomski para defender que uma reação ocupa um papel integrador em relação às demais do sistema, argumentando que "reflexo mais reflexo não é igual a dois reflexos, mas a alguma nova forma de comportamento" (VIGOTSKI apud VAN DER VEER, VALSINER, 2001, p.150).

O questionamento crítico de Vigotski às ideias de Kornilov começa a aparecer de forma mais explícita em 1926, sobretudo no seu artigo sobre a crise na psicologia (VIGOTSKI, 1927/2004). Van der Veer e Valsiner (2001) apontam que tal ruptura é deflagrada quando Vigotski questiona a afirmação de Kornilov de que a psique é função do cérebro, em virtude de seu caráter mecanicista. No entanto, a insuficiência da abordagem de Kornilov em relação à aplicação da filosofia marxista à psicologia parece ter sido a principal motivação, haja vista as duras críticas que Vigotski fez a Kornilov no referido texto (VIGOTSKI, 1927/2004). Deve-se destacar também a intenção de Vigotski de buscar um princípio explicativo geral para a psicologia, que fosse capaz de articular o conceito abstrato de materialismo dialético e as questões concretas da psicologia (TEIXEIRA, 2005), papel que não poderia ser suprido pelo reflexo, dada sua insuficiência teórica e reducionismo biológico. Vigotski tinha um domínio mais profundo sobre a filosofia marxista do que Kornilov, o que vai tornando sua afiliação à reatologia insustentável, ainda que não tenha claro, neste momento, o que seria exatamente uma psicologia marxista. Não obstante, para Vigotski já se tornara evidente que a abordagem metodológica da psicologia deveria ser feita a partir do materialismo histórico-dialético.

É importante destacar que a crítica a uma abordagem mecanicista da relação entre psique e cérebro é fundamental nesse momento, e estará presente em toda a obra vigotskiana, sendo um de seus principais fundamentos. Depara-se aqui com o escopo desta tese, ou seja, como a questão do cérebro aparece na obra de Vigotski, relacionada com sua concepção da 
dialética mente e corpo. Na psicologia histórico-cultural, o cérebro não exerce meramente o papel de um órgão biológico, e pode ser conceituado como a base material da consciência.

As pesquisas sobre o cérebro ou a base material da consciência marcaram a produção inicial da Troika, podendo-se citar como exemplos os estudos de Leontiev sobre a memória (publicado em 1931 na União Soviética, em seu livro Desenvolvimento da memória, que foi prefaciado por Vigotski) e as investigações de Luria sobre o desenvolvimento das funções psíquicas superiores em seus estudos interculturais com os povos do Uzbequistão (LURIA, 1990).

Não obstante, a reflexologia não é abraçada por Vigotski de forma acrítica, pela adoção conceitual pura e simples, mas de forma dialogada, como quem quer articular o conceito de reflexo a uma perspectiva metodológica que considere a consciência como objeto principal de estudo, e não como simples resultado de reflexos concatenados. Não se pode falar, portanto, de uma "conversão" de Vigotski ao materialismo histórico-dialético e subsequente abandono da reflexologia: os elementos de crítica dessa perspectiva teórica estão presentes desde suas obras iniciais e não se ausentam com a evolução de sua teoria, mas antes se incorporam em outro nível de análise, característica do pensamento vigotskiano e de sua maneira peculiar de articular dialeticamente conceitos contraditórios. A leitura reflexológica da perspectiva orgânica da consciência e da psique do início da sua obra é paulatinamente enfraquecida e incorporada em sua teoria, atravessa um momento de aparente hibernação quando o autor se dedica aos aspectos semiológicos da linguagem e seu papel fundamental na constituição do psiquismo humano, e ressurge de forma elegantemente reelaborada quando do seu crescente interesse, no final da vida, pelos estudos neurológicos e psiconeurológicos. Como afirma Teixeira (2005), desde o seu primeiro trabalho publicado sob a direção de Kornilov, o texto de 1926 A consciência como problema da psicologia do comportamento, Vigotski é claramente marxista quando afirma a gênese social da consciência.

A perspectiva biológica, com base na teoria dos reflexos, é posteriormente abandonada por Vigotski, em nome de uma abordagem social do fenômeno psíquico? Ou é incorporada pelo autor, sendo constantemente articulada a uma análise social do fenômeno psíquico, que pressupõe um aparato biológico determinado e determinante desses fenômenos? Aqui será defendida a segunda tese. 
Porém, antes de passar-se a esta análise propriamente dita, é relevante deter-se sobre um dos aspectos mais fundamentais e característicos do pensamento vigotskiano: a importância conferida ao método de pesquisa.

\subsection{Uma questão de método: os fundamentos da psicologia histórico-cultural no materialismo histórico-dialético}

As ideias básicas que possibilitam entender o papel fundamental conferido por Vigotski ao método científico na psicologia foram expostas principalmente em seu texto $O$ significado histórico da crise da psicologia (VIGOTSKI, 1927/2004). Escrito em 1926, mas aparecendo como 1927 nas obras do autor, segundo Van der Veer e Valsiner (2001), este texto foi publicado pela primeira vez apenas em 1982, na edição das obras completas em russo.

Neste texto, Vigotski basicamente defende a necessidade de um princípio unificador em psicologia, ou uma psicologia geral que unifique todas as outras, para cujo processo o método de investigação científica é fundamental. Seria este o lugar a ser ocupado pelo método materialista histórico-dialético na psicologia, ensejando então a construção de uma psicologia marxista, tarefa até então tentada sem sucesso pelos psicólogos russos.

O texto sobre a crise da psicologia parece marcar um ponto de virada na produção de Vigotski, no qual fica clara sua insatisfação com a apropriação dos conceitos marxistas que era feita por Kornilov e seus seguidores. Ele aponta ali que não bastava fazer analogia entre conteúdos de investigação psicológica e termos da filosofia marxista, mas que o grande salto a ser dado era a incorporação do materialismo histórico-dialético como método de pesquisa psicológica.

Reconhecer que o materialismo histórico-dialético deve ser o método da psicologia é reconhecer o papel da filosofia junto à ciência, o que é fonte de uma discussão clássica em psicologia, quando acontecem as primeiras tentativas de separação desta da filosofia na busca de constituir uma ciência autônoma, com base experimental, personificada na fundação do primeiro laboratório de psicologia por Wundt, em 1879. A psicologia histórico-cultural, no entanto, caracteriza-se por sua busca de um referencial filosófico no materialismo histórico-dialético, tendo claro desde o princípio que uma teoria científica não 
se coloca de forma isolada de um fundamento filosófico e de uma concepção de mundo (SHUARE, 1990).

Shuare (1990) aponta como característico do enfoque filosófico no materialismo histórico-dialético em psicologia os seguintes aspectos: 1) dialética; 2) teoria do reflexo; 3) atividade; 4) natureza social do homem (p.17). Resumidamente, seguem-se as definições destes conceitos:

1) A dialética caracteriza-se pela ideia de que os fenômenos estão essencialmente vinculados, desenvolvendo-se através da luta interna entre polos opostos e complementares, a unidade e luta dos contrários. O sistema em que os fenômenos são produzidos deve ser conhecido através da abstração do concreto, por unidades de análise onde o objeto possa ser minimamente representado.

2) A teoria do reflexo da realidade propõe que o conhecimento deve ser adequado ao objeto, refletindo-o. A atividade psíquica teria então um caráter reflexo (o que não é o mesmo que dizer que ocorre apenas através de reflexos condicionados), que seria o reflexo psíquico da realidade. Importante ressaltar que a teoria do reflexo aqui apresentada não deve ser confundida com a teoria dos reflexos de Pavlov ou Bekterev.

3) O conceito de atividade pressupõe uma unidade entre teoria e prática, sendo a essência do homem e do mundo humano, e tendo no trabalho, ou na transformação e adaptação da natureza, sua manifestação superior. Os produtos da atividade humana demonstram como o subjetivo torna-se objetivo, possibilitando deste modo o estudo da psique humana.

4) Quanto à natureza social humana, para o materialismo histórico-dialético a sociedade não deve ser vista como algo externo a que o homem deve adaptar-se, e sim aquilo que cria o ser humano. Isso não significa que o homem seja um objeto passivo diante de forças externas, pois é ao mesmo tempo produto e produtor das relações sociais. Ao homem não basta nascer, ele deve incorporar o desenvolvimento histórico da sociedade humana (SHUARE, 1990). 
De acordo com Almeida (2008, p.18), a questão da relação entre sujeito e objeto está presente desde as primeiras obras de Marx:

\begin{abstract}
Marx aborda a relação objetivação/apropriação, isto é, o processo pelo qual o homem torna subjetivos os objetos (materiais ou não) da realidade pela apropriação, e objetiva os elementos por ele apropriados, ou seja, torna objetivo (exterioriza) o subjetivo. Enfim, o homem em sua relação com a natureza se apropria desta, subjetivando (objetificando) suas relações, assim como objetiva-se por meio do trabalho, transformando intencionalmente a natureza para a satisfação de suas necessidades.
\end{abstract}

Para o materialismo histórico-dialético, o psiquismo humano seria a expressão mais elevada e complexa da natureza, que se dá através do cérebro humano, como foi explicitado em 1878 por Engels (apud ALMEIDA, 2008, p.21).:

Mas, se queremos, na realidade, saber o que são o pensamento e a consciência e de onde procedem, saberemos, então, que são produtos do cérebro e o próprio homem nada mais é do que um produto natural que se formou e se desenvolveu dentro de seu ambiente e com ele.

O reflexo da realidade, ou o material que é tornado mental, vem da experiência social humana, da produção social. Pelo processo dialético constante de objetivação/subjetivação, as necessidades humanas vão se tornando cada vez mais humanizadas, ou seja, necessitam de objetos humanizados para sua satisfação. Vão se formando representações sobre sensações, cada vez mais elaboradas, bem como conceitos e abstrações, que são confirmadas pela prática e assim sucessivamente. Contudo, o reflexo não é especular, uma mera impressão resultante de sensações e percepções, mas uma imagem elaborada da realidade, envolvendo aspectos subjetivos relacionados à experiência individual ${ }^{19}$. Conforme Lênin, o "reconhecimento da regularidade objetiva da natureza e do

\footnotetext{
${ }^{19}$ É interessante observar que as pesquisas atuais em neurociências confirmam que a percepção humana não resulta de uma simples impressão da realidade, ou seja, uma mera transposição de impressões sensoriais para o córtex, mas envolvem sofisticados processos de interpretação destas informações, bem como apontam a influência do contexto na interpretação do dado perceptual. Um exemplo disso pode ser visto nas ilusões de ótica, quando o cérebro cria a impressão de diferentes tamanhos ou cores, por exemplo, baseado na interpretação do contexto de onde provém aquela informação. Não se percebe, portanto, a realidade como ela é, mas como "deveria" ser, de acordo com a interpretação cortical, que é construída pelas experiências humanas. Outro exemplo a este respeito é a percepção de diferentes tons de branco pelos inuítes (membros da nação indígena esquimó), ou seja, as cores são construídas pelo cérebro (SACKS, 1995). Tais evidências são atualmente pesquisadas através de estudos de imageamento cerebral, indicando que algumas áreas relacionadas com cada tipo de percepção são mais ou menos desenvolvidas de acordo com a experiência sensorial vivenciada culturalmente - por exemplo, o estudo com os taxistas de Londres (SPIERS, MAGUIRE, 2006) ou com violinistas (ELBERT et al, 1995), cujas áreas cerebrais refletem o treino específico de cada um na localização espacial nas ruas de Londres ou no treino musical com o instrumento.
} 
reflexo aproximadamente exato desta regularidade no cérebro do homem é materialismo" (apud ALMEIDA, 2008, p.26, grifado por Almeida). O homem não pode captar a realidade como um todo, mas forma conceitos sobre ela, aproxima-se do que existe objetivamente, admitindo suas contradições, e a transforma, num processo constante, compreendendo-a historicamente ou em seu movimento (conforme KOPNIN apud ALMEIDA, 2008, p.29).

\begin{abstract}
Em síntese, o psiquismo (e, assim, a consciência) não se origina dos processos fisiológicos (cérebro), mas tem sua origem nas relações materiais entre o homem e a natureza, sendo essa realidade apropriada pelo homem em sua atividade sensível, por meio da sensibilidade, com o auxílio do cérebro - e dos processos psicológicos e elaborada pelo homem, desenvolvendo seu reflexo psíquico consciente da realidade, isto é, a apreensão das contradições e mediações dos objetos e a possibilidade de conhecer a realidade aproximando-se eternamente de sua totalidade. É pela objetivação desse conhecimento que o homem não somente constata a verdade de suas elaborações (conceitos), mas também apreende novos elementos para a contínua apropriação das contradições do mundo sensível. (ALMEIDA, 2008, p.30).
\end{abstract}

No materialismo dialético, utiliza-se o conceito de categorias, ou segundo o próprio Marx, “formas de ser, características da existência” (MARX apud DEÁK, 2005). As categorias constituem os processos sociais, de acordo com a visão de uma determinada teoria. São exemplos de categorias dialéticas o singular e o universal, a causa e o efeito, a essência e o fenômeno, a forma e o conteúdo, entre outras. Teixeira (2005) assinala que as categorias no materialismo dialético existem de forma independente da consciência, ao mesmo tempo em que são um produto da forma de organização específica do cérebro. Os fenômenos são captados pelo cérebro através da percepção, que os organiza, decodifica e interpreta portanto, "as leis da matéria são as mesmas leis do pensamento" (TEIXEIRA, 2005, p.70). As categorias são produto da capacidade reflexiva humana, e embora dominem e organizem o pensamento, foram retiradas por ele da realidade empírica (VIEIRA PINTO, apud TEIXEIRA, 2005). Este processo de passagem do conhecimento do concreto real ao concreto pensado, através da abstração, é resumido da seguinte forma por Teixeira (2005, p.76):

A realidade manifesta-se imediatamente aos nossos sentidos; passa-se, então, pela via da abstração, à captação das múltiplas determinações do real, imperceptíveis imediatamente aos sentidos; chega-se à apropriação, pelo pensamento, das múltiplas determinações, ou seja, ao concreto no pensamento.

Pode-se observar que a psicologia soviética articula-se explícita e intencionalmente com estes conceitos, que estão presentes de forma essencial nas propostas teóricas de Vigotski. Devido a seu domínio filosófico do materialismo histórico-dialético, 
Vigotski pôde perceber claramente os equívocos que estavam sendo cometidos na apropriação desta base teórica pelos pesquisadores em psicologia de sua época, seja na concepção mecanicista de Pavlov e Bekterev ou na reatologia de Kornilov, situação analisada em seu texto sobre a crise na psicologia (VIGOTSKI, 1927-2004), em que assinala a necessidade da psicologia construir seu " $O$ capital". Vigotski evidencia deste modo a necessidade de criar uma psicologia que se articule com os princípios do materialismo histórico-dialético, e nesta tentativa progressivamente vai delineando os fundamentos da psicologia histórico-cultural ${ }^{20}$.

Rossetti-Ferreira et al. (2008) discutem o conceito vigotskiano do pesquisador como um ferramenteiro, segundo o qual o método é algo a ser praticado, indo além de uma ferramenta a ser aplicada com vistas à obtenção de um fim determinado. Assim, para Vigotski o método não pode ser separado daquilo que é sua finalidade, tendo defendido a "noção dialética de 'instrumento-e-resultado', algo que é, ao mesmo tempo, pré-requisito e produto, ferramenta para conhecer e também o resultado do estudo.” (p.164). Reportando-se a Newman e Holzman (2002, apud ROSSETTI-FERREIRA et al., 2008), as autoras referem que há na sociedade industrial contemporânea dois tipos de instrumentos: os feitos em massa para a obtenção de um resultado imediato (como um martelo) e os feitos por ferramenteiros para produzir outros instrumentos (como a ferramenta para fabricar martelos). Este segundo tipo não visa um resultado específico (como pregar um prego), e sim agir sobre e transformar "totalidades históricas", o que seria análogo à função do pesquisador e da investigação científica do ponto de vista vigotskiano. Portanto,

as ferramentas psicológicas - conceitos, formas de observar, registrar, analisar, argumentar, construir tabelas, entrevistar, formular novos conceitos -, elementos historicamente elaborados pelos seres humanos para pensar o mundo, são os instrumentos com que o pesquisador trabalha para orientar sua ação investigativa. (p.165)

Delari Junior (2009) sugere que o método em Vigotski não é entendido como um procedimento operacional, e sim como um meio de cognição, conforme apontado por ele em seu texto sobre a crise na psicologia (VIGOTSKI, 1927/2004). O método instrumental ou construtivo proposto por Vigotski enfoca as estruturas artificiais ou construídas em oposição

\footnotetext{
${ }^{20}$ Para Elhammouni, no entanto, Vigotski atingiu tal objetivo de maneira parcial, comparando-o com Feuerbach em relação ao materialismo até a crítica de Marx (cf. ELHAMMOUNI, 2004).
} 
às naturais, bem como não se restringe a analisar, mas constrói processos (VIGOTSKI, 1930 apud DELARI JUNIOR, 2009). Esta construção acontece na medida em que o pesquisador introduz meios artificiais ou criados culturalmente (os signos) como ferramentas aplicáveis ao processo de pesquisa, onde se dá, portanto, uma "intervenção intencional", em oposição à ideia de "descoberta espontânea" (DELARI JUNIOR, 2009).

A preocupação de Vigotski com a questão do método é evidente em sua obra. Desde seus textos mais iniciais, como Psicologia da Arte, de 1925, pode-se observar a presença de um capítulo ou item referindo-se ao método (DELLARI JUNIOR, 2009).

A título de ilustração, observe-se o segundo capítulo da História do desenvolvimento das funções psicológicas superiores, intitulado Método de investigação (VYGOTSKI, 1931/2000), também resumido e publicado no capítulo cinco, Problemas de método, na coletânea A formação social da mente (VIGOTSKI, 2007), onde Vigotski faz uma descrição aprofundada do que seria a abordagem metodológica no estudo das funções psicológicas superiores, realizando um esforço teórico para propor uma metodologia adequada a tal objeto de estudo.

Nesse trabalho, Vigotski afirma que a estrutura estímulo-resposta embasa todos os experimentos em psicologia. Com isso, no entanto, o autor não pretendia dizer que não há diferenças fundamentais entre as diferentes escolas psicológicas, mas que estas compartilham uma fundamentação na ciência experimental. No entanto, Vigotski aponta que, ainda que o método experimental tenha sido eficiente na pesquisa de processos psicofisiológicos elementares, é insuficiente no que se refere ao estudo das funções psicológicas superiores ou especificamente humanas. Tal análise fundamenta-se nos pressupostos do materialismo histórico-dialético, segundo os quais o comportamento humano difere de forma qualitativa do comportamento animal, o que implica na necessidade de buscar uma metodologia específica para a experimentação psicológica, e juntamente com ela, uma nova estrutura analítica.

A partir dessa necessidade, Vigotski propõe três princípios para a análise das funções psicológicas superiores (VIGOTSKI, 2007, p.63-69), que podem ser destacadas aqui como propostas metodológicas:

1) Análise de processos $x$ análise de objetos: deve-se enfocar os processos tendo em mente seu desdobramento histórico. Assim, a psicologia do desenvolvimento, por seu caráter histórico, é mais pertinente ao estudo das funções psicológicas superiores do que a 
psicologia experimental. O que se busca não é isolar fatos, mas estudá-los no seu processo dinâmico de desenvolvimento. Vigotski refere que seu método pode ser chamado de "desenvolvimento-experimental", uma vez que cria artificialmente processos de desenvolvimento psicológico para estudá-los.

2) Explicação x descrição: Vigotski conceitua como análise genotípica o processo de explicar um fenômeno com base em sua origem e não em sua aparência externa ou fenotípica. Para analisar um problema na perspectiva do desenvolvimento deve-se buscar revelar sua gênese e suas bases dinâmico-causais. Este tipo de análise abarca tanto as manifestações externas quanto o processo em si, não desconsiderando mas subordinando os aspectos fenotípicos aos genéticos.

3) Comportamento fossilizado: são aqueles processos psicológicos resultantes de um longo período de desenvolvimento histórico, devido ao que se tornaram fossilizados, ou seja, automatizados. Na aparência, tais processos podem ser semelhantes aos estágios primários do desenvolvimento, quando na verdade trata-se de uma etapa posterior desse processo. Para estudar os comportamentos fossilizados é preciso reconstruir suas etapas e buscar sua origem, concentrando-se no processo e não no produto final do desenvolvimento. Vigotski conclui que estudar algo historicamente não é estudar um evento passado, e sim estudá-lo no processo de mudança, sendo esse o requisito básico do processo dialético.

Após a apresentação deste exemplo da abordagem metodológica vigotskiana, apresentam-se de forma resumida os fundamentos da psicologia histórico-cultural, procurando-se desde o início destacar o papel que nela ocupa o cérebro ou a base material da consciência.

\subsection{A psicologia histórico-cultural e a base material da consciência}

O período transcorrido desde a aparição de Vigotski no cenário científico, com sua apresentação no congresso de psiconeurologia em 1924, até sua morte precoce como consequência da tuberculose, em 1934, marcou-se por abundante produção científica do autor 
em diversas áreas. A assimilação e discussão consolidada da obra vigotskiana, apesar de sua crescente popularidade, sobretudo no Brasil ${ }^{21}$, ainda está sendo feita e pode ser considerada em estado incipiente (principalmente em alguns temas, como a questão da base biológica da psique aqui abordada, em detrimento de outros, como mediação, sentido/significado e deficiência, temáticas mais recorrentes na pesquisa em educação). Portanto, não se pretende aqui fazer uma síntese acabada da mesma, mas apenas destacar seus aspectos mais significativos pelo prisma desta tese, visando à construção de um pano de fundo no qual serão destacados alguns aspectos para análise.

Teixeira $(2005$, p.14) destaca três tópicos como sendo fundamentais à psicologia histórico-cultural: a) o conceito de materialismo dialético, b) o percurso histórico da constituição da psicologia histórico-cultural e c) o modo como esta concebe a constituição do humano. Ou seja: a partir do materialismo dialético aplicado como método à psicologia, Vigotski propõe o papel fundamental da história e da cultura na constituição do psiquismo humano.

Wertsch (1996, p.9) também aponta três grandes temas recorrentes nos trabalhos de Vigotski: a) o uso de um método genético, ou de desenvolvimento; b) a afirmação de que o funcionamento mental superior do indivíduo provém de processos sociais; e c) a afirmação de que os processos sociais e psicológicos humanos são moldados fundamentalmente por ferramentas sociais, ou formas de mediação. O método genético ressalta o desenvolvimento humano enquanto um processo histórico, que se dá através de sucessivas etapas e em relação dialética com um contexto sócio-cultural específico. Esse processo torna-se a base do desenvolvimento, na medida em que tais dinâmicas sociais são apropriadas pela pessoa e passam a constituir o seu psiquismo a partir de ferramentas sociais, das quais a linguagem pode ser destacada como a fundamental.

21 No site Itinerários vigotskianos: a produção bibliográfica brasileira (disponível em <http://www2.uel.br/ ccb/psicologia/Pesquisa/Itinerários Vigotskianos.htm>, acesso em 7 mar. 2011), do grupo de pesquisa Psicologia e Educação: Perspectiva Sócio-Histórica-Cultural, vinculado ao Departamento de Psicologia Social e Institucional da Universidade Estadual de Londrina, pode-se acessar uma listagem em construção de publicações brasileiras sobre Vigotski, incluindo artigos, dissertações, teses, livros e capítulos de livros. Apenas para ilustrar o argumento da crescente produção brasileira sobre o tema, compare-se: o número de artigos publicados em 1990 (6), em 2000 (47) e em 2006 (66). 
Shuare (1990) defende que a aplicação do materialismo histórico-dialético à psicologia soviética feita por Vigotski foi uma "revolução copernicana" na psicologia como ciência. A autora aponta como eixo organizador da obra de Vigotski seu caráter histórico, assinalando que ele não apenas introduz a dimensão temporal em psicologia, mas sim “introduz a psique no tempo" (p.59), sendo esta a essência da psicologia histórico-cultural. Não se trata aqui de uma noção abstrata de tempo, mas do tempo humano, histórico, tanto do ponto de vista individual quanto social. Segundo a autora, nos seres humanos

\begin{abstract}
a natureza sócio-cultural não coexiste nem se superpõe à natureza "natural", mas sim a transforma, submetendo-a a lei de ordem superior. Como diz Vigotski: "devido ao desenvolvimento orgânico (da criança) realizar-se em um meio cultural, ele se converte em um processo biológico historicamente condicionado" ${ }^{22}$ (p.60).
\end{abstract}

Shuare (1990) sugere ainda que, a partir do eixo histórico da psicologia históricocultural, são produzidos três desdobramentos: a) o tempo humano é histórico do ponto de vista individual e social, para cuja compreensão a atividade produtiva do homem é essencial; b) a psique humana está em constante processo de desenvolvimento histórico relacionado à atividade social, formando-se no espaço-tempo da relação entre o homem e o mundo; c) o caráter mediado da psique humana, pelos instrumentos ou signos criados pelo homem a fim de dominar o comportamento (seu ou do outro). A autora retoma a definição de Vigotski sobre a natureza social da psique humana:

Modificando a conhecida tese de Marx, poderíamos dizer que a natureza psíquica do homem é o conjunto das relações sociais transferidas para o interior e transformadas em funções da personalidade e formas de sua estrutura. Não pretendemos dizer que seja este, exatamente, o significado da tese de Marx, mas vemos nesta tese a expressão mais completa de todo o resultado da história do desenvolvimento cultural $^{23}$ (SHUARE, 1990, p.65-66).

\footnotetext{
${ }^{22}$ No original: "En el hombre, la naturaleza sociocultural no coexiste ni se superpone a la naturaleza 'natural', sino que transforma a ésta, sometiéndola a leyes de orden superior. Como dice Vigotski: 'Por cuanto el desarrollo orgánico (del niño) se realiza en un medio cultural, se convierte en un processo biológico históricamente condicionado'.
}

\footnotetext{
${ }^{23}$ No original: "Modificando la conocida tesis de Marx, podríamos decir que la naturaleza psíquica del hombre representa el conjunto de las relaciones sociales, trasladadas al interior y convertidas en funciones de la personalidad y formas de su estructura. No queremos decir que tal es el significado de la tesis de Marx; pero nosotros vemos en esta tesis la expressión más completa de aquello a que nos conduce la historia del desarrollo cultural". Este texto foi cotejado aqui com a forma em que aparece nas Obras Escogidas, tomo III, p.151: "Modificando la conocida tesis de Marx, podríamos decir que la naturaleza psíquica del hombre viene a ser un conjunto de relaciones sociales trasladadas al interior y convertidas en funciones de la personalidad y en formas de su estructura. No pretendemos decir que ese sea, precisamente, el significado de la tesis de Marx, pero vemos en ella la expressión más completa de todo el resultado de la historia del desarrollo cultural".
} 
Esta proposição, que será estudada em pormenor mais adiante, refere-se à tese de que, para Vigotski, no desenvolvimento humano as funções psicológicas aparecem duas vezes: inicialmente no plano social, como função entre duas pessoas ou função interpsicológica, e outra vez no plano psicológico, como função de um indivíduo isoladamente ou função intrapsicológica, mediante um processo de internalização que não se resume a uma mudança de lugar, mas é uma transformação estrutural da função, de inferior para superior ou especificamente humana, fruto de um processo mediado socialmente. As funções psicológicas tipicamente humanas (como a memória mediada, a atenção dirigida e outras) são denominadas por Vigotski como funções psicológicas superiores. A elas contrapõem-se as funções psicológicas inferiores ou elementares (ou seja, a memória por imagens ou a atenção reflexa, por exemplo), que são aquelas com caráter reflexo ou herdado.

Puziréi argumenta que "o eixo da concepção histórico-cultural é a orientação para investigar o desenvolvimento do psiquismo [...] em certo sentido, não se estuda nada mais que o desenvolvimento psíquico" (apud TEIXEIRA, 2005, p.9). Segundo esta concepção, o processo de desenvolvimento humano é um processo artificial, fruto de uma intervenção deliberada com a finalidade de reorganizar constantemente a psique e sua forma de funcionamento. Portanto, o fator determinante do comportamento humano deve ser buscado na sociedade.

Rivière (1984, p.44), assumindo o risco que esquematizações desse tipo possam trazer, sintetiza de forma bastante didática os principais pressupostos da psicologia históricocultural (grifos meus):

- A unidade de análise da psicologia histórico-cultural é a atividade instrumental. O ato instrumental se transforma em ato significativo através da relação com os outros.

- As funções psicológicas superiores se desenvolvem através da internalização dos processos de relação social. Sua origem não está no desdobramento do espírito ou no amadurecimento de conexões cerebrais, mas na história social. As funções psicológicas superiores implicam na combinação de ferramentas e signos na atividade psicológica.

- A atividade transformada em signo é condensada. Os signos são, originariamente, mediações para regular a conduta dos outros. Os outros regulam a conduta da criança 
através dos signos, assim como a criança aprende a regular a conduta dos outros também através de signos.

- A cultura proporciona as ferramentas simbólicas necessárias para a construção da consciência e das funções psicológicas superiores, que são, fundamentalmente, os símbolos linguísticos.

- O desenvolvimento não consiste na progressiva socialização de um indivíduo originalmente "autista", e sim na individualização de um organismo basicamente social desde o início. O indivíduo é um destilado das relações sociais, ou seja, o indivíduo é uma organização consciente de processos e funções internas a partir dos signos, que possibilitam a atividade voluntária e a autorregulação ou controle sobre si mesmo.

- Para superar a cisão e a crise entre uma psicologia objetiva das funções elementares e uma psicologia subjetiva e idealista das funções superiores, deve-se estabelecer o elo entre ambas a partir de um paradigma unificador, que está fora do indivíduo, nas relações sociais. Só assim será possível recuperar o próprio sujeito a partir de uma perspectiva científica e explicativa.

Rivière (1984) destaca também a coerência da teoria vigotskiana com seus conhecimentos acerca da filogênese do homem. A conduta instrumental e cooperação social refletem a evolução dos hominídeos, desde a liberação das mãos pela postura bípede e daí a criação de ferramentas e a organização grupal voltadas para a transformação da natureza. Vigotski não acreditava que a ontogênese era uma simples recapitulação da filogênese - a perspectiva evolucionista de seu trabalho apóia-se na concepção evolucionista da própria ontogênese (RIVIÈRE, 1984, p.45).

Van der Veer e Valsiner (2001) asseveram que Vigotski conhecia bem a teoria da evolução de Darwin, valorizando-a enquanto abordagem científica genérico-causal, ou seja, uma classificação com base na origem comum. Contudo, discordava da proposição de Darwin quanto à diferença entre as faculdades mentais humanas e dos animais tratarem-se apenas de uma diferença de grau, mas sim de diferenças fundamentais originadas no inicio da cultura humana. Segundo o pensamento marxista, a filogênese do homem atravessa dois períodos 
distintos: primeiro, o da evolução biológica (aquele caracterizado por Darwin) e depois o período da história humana, conforme descreveram Marx e Engels. Os animais dependem exclusivamente da herança genética, enquanto os seres humanos podem transmitir e dominar os produtos da cultura, que permitem sua emancipação da natureza. Vigotski admitia a existência de uma base genética no comportamento, mas ressaltava que a mesma se resumia aos processos inferiores. Os processos de comportamento e pensamento especificamente humanos desenvolviam-se através da história humana e, diferentemente dos filhotes dos animais, tinham que ser dominados por cada criança humana inserida em um processo de interação social.

Os conceitos básicos da psicologia histórico-cultural aqui resumidos serão revisitados oportunamente, quando da análise dos textos do autor, conforme será explicado no decorrer desta tese. Passa-se na sequência discutir de forma específica o conceito de cérebro na psicologia histórico-cultural, apresentando a metodologia utilizada nesta tese. 


\title{
A PESQUISA REALIZADA: OBJETIVOS E PROCEDIMENTOS
}

\begin{abstract}
A psique [...] é uma parte da própria natureza, ligada diretamente às funções da matéria altamente organizada de nosso cérebro. Assim como o resto da natureza, não foi criada, mas surgiu num processo de desenvolvimento. [...]

[É uma] expressão subjetiva desses mesmos processos, como uma faceta especial, uma característica qualitativa especial das funções superiores do cérebro.
\end{abstract}

$\left(\right.$ Vigotski $\left.^{24}\right)$

Em sua obra, Vigotski refere-se frequentemente ao cérebro, observando-se o aumento do seu interesse específico pelo funcionamento cerebral por volta de 1930, período que em que retoma seus estudos de medicina. Van der Veer e Valsiner (2001) mencionam que Vigotski tinha conhecimento dos estudos de Edinger (1855-1918) e Kretschmer (1888-1964) sobre a anatomia e fisiologia do cérebro. Este último postulou alguns princípios do desenvolvimento cerebral e da relação entre as funções superiores e inferiores que influenciaram as ideias de Vigotski em relação ao seu conceito de funções psicológicas superiores. Tais funções surgem como resultado do processo de desenvolvimento, onde funções anteriormente separadas são reorganizadas e aperfeiçoadas, o que resulta em uma modificação qualitativa destas relações, gerando novas unidades funcionais (entendendo-se unidade aqui no sentido que é dado por Vigotski, ou seja, a unidade mínima de elementos necessários para uma análise sem que se percam as características essenciais do fenômeno em pauta).

Outro constructo teórico que exerceu influência nas ideias de Vigotski foi o conceito de dominante de Ujtomski, que postula a atuação do cérebro enquanto sistema, cuja organização funcional pode ser encontrada nas conexões entre diferentes partes do cérebro.

\footnotetext{
${ }^{24}$ In: A psique, a consciência, o inconsciente (VIGOTSKI, 1930/2004, p.144).
} 
Este conceito, no entanto, conforme afirmam Van der Veer e Valsiner (2001), não foi tão útil do ponto de vista experimental para Vigotski quanto o material de casos neurológicos que a literatura científica vinha produzindo, notadamente o aumento do conhecimento sobre o funcionamento do cérebro como decorrência da Primeira Guerra Mundial, favorecendo que Vigotski encontrasse evidências nas quais pudesse apoiar suas hipóteses.

Vigotski também se interessou pelo processo de desenvolvimento e decomposição das funções psicológicas superiores, sinalizando para a importância da análise estrutural desses processos e das relações interfuncionais do cérebro. Formulou o conceito de sistema psicológico para resolver a questão entre a concepção localizacionista e a global, conceito que foi a base para o posterior desenvolvimento da neuropsicologia por Luria.

De acordo com Iwao (1996), um sistema psicológico consiste num agrupamento de funções mentais diversas, como memória, percepção, imaginação e outras que emergem do funcionamento mental, caracterizando também a mente ou consciência como um todo.

É importante ressaltar que o interesse nas patologias do desenvolvimento foi manifestado por Vigotski desde o início da sua trajetória científica. Dedicou-se ainda ao estudo do papel da linguagem no desenvolvimento humano através de casos clínicos envolvendo patologias da linguagem, no caso, a afasia, bem como as demências e as doenças de Parkinson e de Pick. De forma geral, enfatizou nesses estudos as características peculiares do desenvolvimento e da desintegração, relacionadas com a idade em que ocorrem, argumentando contra as hipóteses localizacionistas em áreas cerebrais restritas.

Shuare (1990, p.69-70) aponta que a concepção histórico-cultural da psique permitiu que Vigotski postulasse de maneira inovadora o problema da localização das funções psíquicas e da relação entre cérebro e psique. Segundo a autora, podem-se destacar três ideias fundamentais: 1) o caráter mutável dos vínculos interfuncionais durante o desenvolvimento infantil; 2) a formação de sistemas dinâmicos complexos, que integram as funções elementares em novas formas de organização, as funções psicológicas superiores; 3) a existência de relações extracorticais na atividade dos centros cerebrais que sustentam o funcionamento das funções psíquicas superiores.

Este desenvolvimento peculiar das funções psicológicas superiores estaria na base da explicação de diferentes consequências em decorrência de traumas no cérebro de acordo com a etapa do desenvolvimento em que ocorrem. Vigotski desenvolveu uma teoria sobre a relação entre a alteração do desenvolvimento e a destruição da função, estabelecendo que o 
desenvolvimento ocorre em direção ascendente, e a destruição, ao contrário, em sentido descendente.

Tal teoria será aprofundada mais adiante neste texto, ao realizar-se um percurso através das obras do autor, que será descrito no próximo item, onde se expõe o núcleo desta tese, bem como a metodologia que foi utilizada na análise do trabalho do autor.

\subsection{Vigotski e o cérebro enquanto base material da consciência}

Neste item, aborda-se como Vigotski compreendeu e conceituou o cérebro humano, ou a base material da consciência, o que constitui o escopo da pesquisa realizada nesta tese. Para tanto, é feito um percurso por alguns de seus textos, selecionados segundo o critério de apresentarem mais especificamente análises sobre a função do cérebro e do sistema nervoso central na constituição do psiquismo humano. Estes textos são aqui apresentados em ordem cronológica, após o que serão discutidos de forma global. As análises feitas pelo autor são comentadas e articuladas entre si, em busca de um percurso acerca do entendimento de Vigotski sobre o cérebro como base material da consciência, bem como do desenvolvimento desses conceitos em sua obra. A partir desta leitura, destacam-se na sequência as principais contribuições de Vigotski na formulação de uma concepção histórico-cultural do cérebro.

Quanto às fontes dos textos examinados, sempre que possível, foi dada preferência à consulta de obras cuja tradução é avaliada como sendo mais legítima em face dos títulos disponíveis. Assim, o material de referência básico são as Obras Escogidas ou obras completas publicadas em espanhol pela editora Visor, de Madrid, em 1997, a partir da primeira edição da coleção lançada pela Editora Piedagouguika, de Moscou, em seis volumes, cuja data de lançamento planejada era de 1982 a 1984. Na edição espanhola, cinco volumes foram publicados, sendo que o sexto volume programado ainda não foi editado. Na edição americana das obras de Vigotski encontra-se o sexto volume, que também foi utilizado como referência. O texto Teoria das emoções, que integraria o sexto volume da edição espanhola, foi consultado em edição avulsa em espanhol (VYGOTSKI, 1931/2004).

Após este breve estado da arte da publicação das obras de Vigotski, cabe também ressaltar que as traduções em língua portuguesa desses trabalhos ainda não estão sistematizadas, sendo que apenas alguns de seus textos foram publicados no Brasil, e em uma 
sequência diferente das publicações espanholas e norte-americanas referidas. Há também a questão da tradução, pois apenas recentemente (a partir de 2001) publicaram-se no Brasil textos vertidos diretamente a partir do russo, e que portanto apresentam menos ruído em relação à obra original do autor. Assim, para o leitor brasileiro, o acesso mais aprofundado à obra de Vigotski não se dá sem alguns percalços. Contudo, sempre que títulos em português estavam disponíveis oriundos de traduções a partir do russo, foi dada preferência a eles nesta tese. No entanto, não foi possível ter acesso a alguns textos em fontes mais credenciadas, pois a única forma disponível para acessá-los foi a publicação em sites da internet (como por exemplo VYGOTSKI, 1931-1933). Sempre que isso ocorre aqui, é esclarecido este detalhe em nota explicativa. E, obviamente, foram tomadas todas as precauções possíveis no sentido de cotejar os apontamentos de tais fontes com as edições mais reputadas.

As Obras Escogidas, as edições em português e os textos avulsos disponíveis na internet foram lidos e submetidos a uma análise inicial, com a finalidade de pinçar os textos onde a questão cérebro/base material da consciência estivesse de algum modo mais destacada. Ao final do processo, foram selecionados vinte trabalhos de Vigotski para a elaboração desta tese, indo desde comunicações mais breves até livros inteiros. Cabe enfatizar que, apesar do tempo de produção teórica de Vigotski ter sido abreviado (suas obras mais específicas em psicologia datam de 1924 a 1934, período em que as obras aqui analisadas foram escritas), isso não impediu que sua produção fosse tão intensa quanto volumosa, o que levou Rivière a compará-lo com um meteoro cruzando os céus da psicologia (RIVIÈRE, 1984).

A temática do cérebro e do sistema nervoso central aparece já em 1924, momento inicial de sua obra, e é pontuada de forma constante até o final da mesma, com sua morte, em 1934. Nas primeiras obras enfocadas (1924 a 1926), nas quais nota-se uma utilização do jargão reflexológico, ainda que de forma crítica, a presença desta temática é mais objetiva, sendo que, posteriormente, o tema aparece de forma mais difusa, principalmente através da teoria dos sistemas funcionais e das funções psíquicas superiores (por volta de 1930). Nas últimas obras escritas (1931-1934), o interesse pela temática cérebro/base material da consciência intensifica-se, provavelmente estimulado pelo fato de Vigotski dar continuidade a seus estudos de Medicina juntamente com Luria, por volta de 1930. Tal interesse provavelmente foi avivado pelo contexto da Primeira Guerra Mundial e das possibilidades para a neurologia que então se descortinavam, com a produção de novos conhecimentos 
advindos da experiência com o tratamento das lesões cerebrais dos combatentes e suas sequelas. O investimento de Vigotski no assunto permanece até as últimas obras escritas em 1934, quando surgem textos específicos sobre a temática da base material da consciência, como A psicologia e a teoria da localização das funções psíquicas e $O$ problema do desenvolvimento e da desintegração das funções psíquicas superiores.

Portanto, a análise de tais produções constitui o método empregado nesta tese. A partir desta análise, pôde-se caracterizar com maior detalhamento o percurso da temática cérebro/base material da consciência neste período, e para a finalidade de apresentar mais didaticamente esse processo, o período considerado foi dividido em quatro momentos. A finalidade didática de tal divisão deve ficar bem estabelecida, uma vez que muitos conceitos fundamentais percorrem as produções enfocadas aprofundando-se ou dissolvendo-se, para novamente surgir em outro nível de abordagem numa próxima ocasião - o que é característico do movimento dialético da escrita de Vigotski, ou seja, dando-se através de teses, antíteses e sínteses, e após, novas teses. Também não se pode falar em fases ou etapas distintas quanto às temáticas na obra de Vigotski, uma vez que o mais provável, dado o volume da produção do autor, é que ele se dedicasse a vários temas de pesquisa simultaneamente, sendo que muitos foram iniciados e permaneceram inconclusos (como é o caso de seus estudos sobre a emoção).

Desta forma, o agrupamento aqui apresentado têm apenas o objetivo de organizar a apresentação dos textos de forma a relacioná-los com as principais temáticas pesquisadas pelo autor no decorrer da sua produção, procurando destacar nesses períodos um eixo que se aproxime do conceito pesquisado, ou seja, sua abordagem sobre o cérebro. Isso se justifica pelo fato de que não há, na opinião expressa na presente tese, uma mudança radical no enfoque da temática cérebro por Vigotski, mas sim uma mudança de foco, com um interesse maior ou menor nesta exploração específica, com maior ou menor aprofundamento.

Apresenta-se a seguir um quadro sintético das produções selecionadas, em ordem cronológica, após o que se faz uma breve caracterização de cada momento focalizado. No Apêndice I são listadas de forma completa as referências das obras consultadas. 
Quadro 2 - Títulos selecionados e momentos do percurso de análise

\begin{tabular}{|c|c|c|}
\hline Momento & Ano & Texto \\
\hline \multirow{4}{*}{$\begin{array}{l}1^{\circ} \text { momento } \\
\text { Palavras-chave: } \\
\text { REFLEXO E } \\
\text { CONSCIÊNCIA }\end{array}$} & 1924 & Os métodos de investigação reflexológicos e psicológicos \\
\hline & 1925 & $\begin{array}{l}\text { A consciência como problema da psicologia do } \\
\text { comportamento }\end{array}$ \\
\hline & 1926 & $\begin{array}{l}\text { Prólogo à versão russa do livro de E. Thorndike, } \\
\text { "Princípios de ensino baseados na psicologia" }\end{array}$ \\
\hline & 1926 & Psicologia pedagógica \\
\hline \multirow{6}{*}{$\begin{array}{l}2^{\circ} \text { momento } \\
\text { Palavra-chave: } \\
\text { INSTRUMENTO }\end{array}$} & 1929 & Manuscrito de 1929 \\
\hline & 1929 & O problema do desenvolvimento cultural da criança \\
\hline & 1930 & A psique, a consciência, o inconsciente \\
\hline & 1930 & O método instrumental em psicologia \\
\hline & 1930 & Sobre os sistemas psicológicos \\
\hline & 1930 & $\begin{array}{l}\text { Estudos da história do comportamento: símios, homem } \\
\text { primitivo e criança. }\end{array}$ \\
\hline \multirow{4}{*}{$\begin{array}{l}3^{\circ} \text { momento } \\
\text { Palavra-chave: } \\
\text { FUNÇÕES } \\
\text { PSICOLÓGICAS } \\
\text { SUPERIORES }\end{array}$} & 1931 & $\begin{array}{l}\text { História do desenvolvimento das funções psíquicas } \\
\text { superiores }\end{array}$ \\
\hline & 1931 & Psicologia educacional [paidologia] do adolescente \\
\hline & 1932 & O primeiro ano \\
\hline & 1931-1933 & Teoria das emoções \\
\hline \multirow{6}{*}{$\begin{array}{l}4^{\circ} \text { momento } \\
\text { Palavra-chave: } \\
\text { CÉREBRO }\end{array}$} & 1932 & O problema mente-corpo \\
\hline & 1934 & A psicologia e a teoria da localização das funções psíquicas \\
\hline & 1934 & Sobre localização \\
\hline & 1934 & $\begin{array}{l}\text { O problema do desenvolvimento e da desintegração das } \\
\text { funções psíquicas superiores }\end{array}$ \\
\hline & 1934 & O pensamento na esquizofrenia \\
\hline & 1934 & Para o problema da demência no Mal de Pick \\
\hline
\end{tabular}




\subsubsection{Primeiro momento. Palavras-chave: REFLEXO e CONSCIÊNCIA}

Textos produzidos entre 1924 e 1926

O primeiro momento apresenta o perfil de um pesquisador ainda ligado aos conceitos básicos da reflexologia de Bekterev e Pavlov. Como já foi mencionado, Vigotski utilizava o conceito de reflexo da maneira como era proposto pela ciência da época, o que não o impediu de criticar a abordagem reducionista dos reflexologistas, particularmente no que se refere à questão da consciência.

As pesquisas de Vigotski no campo da defectologia, empreendidas nesta época, entre 1924 e 1927, serviram a ele como uma possibilidade experimental para testar suas hipóteses acerca da consciência e estrutura do comportamento humano, conforme aponta Veresov (1990). Na época, havia pouco interesse em pesquisa aplicada, e portanto não havia dados empíricos onde Vigotski pudesse apoiar suas hipóteses. Na defectologia, Vigotski viu "o potencial para testar as possibilidades de modificar a estrutura do comportamento humano em um contexto especial, emergindo deste comportamento para formas sociais ${ }^{25}$, (VERESOV, 1990, p.129). Lordelo e Tenório (2010) corroboram que o conceito de consciência foi considerado como uma categoria fundamental pelo autor, o que não impediu que tal conceito sofresse reelaborações no decorrer da obra de Vigotski. Wertsh (1988) afirma que a leitura de Vigotski sobre a consciência decorre da sua insistência no estudo da atividade psicológica complexa como um processo interfuncional, que não deveria ser abordado de forma fragmentada. Assim, a expressão que pode sintetizar este primeiro momento da análise é Reflexo e Consciência.

O tema da consciência é discutido por Vigotski no trabalho apresentado no Segundo Congresso de Neuropsicologia em março de 1924, intitulado Os métodos de investigação reflexológicos e psicológicos (VIGOTSKI, 1924-1926/2004), com o qual se inaugura esse primeiro momento.

Na sequência, foi selecionado o texto de 1925 A consciência como problema da psicologia do comportamento (VIGOTSKI, 1925/2004). Neste texto, que se inicia com o

\footnotetext{
${ }^{25}$ No original: "[...] a potential there for the testing of possibilities to change the structure of human behavior in a special context, raising that behavior to social forms." (VERESOV, 1990, p.129).
} 
famoso exemplo tomado de Marx acerca das abelhas, formigas e arquitetos, Vigotski radicaliza (no sentido de ir às raízes mais profundas de algo) suas ideias sobre a forma como a reflexologia trata a questão da consciência, expressas de forma inicial na conferência de 1924, onde fica explícita sua não adesão aos princípios reflexologistas.

O próximo texto, de 1926, é Prólogo à versão russa do livro de E. Thorndike "Princípios de ensino baseados na psicologia" (VIGOTSKI, 1926/1991), que o autor classifica como um texto de transição, necessário enquanto se vive o processo de construção da nova psicologia e ainda não se dispõe de livros-texto adequados, mas não definitivo. Tratase de um bom exemplo do estilo de prefaciar de Vigotski, que não se resumia a uma apreciação distanciada da obra em pauta, mas num diálogo crítico com as ideias do autor.

A seleção se encerra com alguns apontamentos do manual Psicologia pedagógica, produzido provavelmente em período anterior a 1924 mas publicado em 1926 (VAN DER VEER; VALSINER, 2001), texto em que, se as referências ao cérebro de forma específica não são profícuas, é interessante para exemplificar a influência de uma visão biológica como fundamentação da psicologia nesta fase inicial, contudo já destacando a influência que o meio social (e histórico) exerciam de forma dialética com o indivíduo na geração do comportamento.

Nesses quatro textos iniciais, a temática da base material da consciência é abordada ainda com base na nomenclatura da teoria dos reflexos, que parecia também ser um constructo de transição para as ideias que a psicologia histórico-cultural colocaria de forma mais clara em seu desenvolvimento posterior. Veresov (1990) defende que a essência dos primeiros trabalhos reflexológicos de Vigotski está na característica fundamental de que o comportamento requer uma análise sistêmica. Tal princípio, em conjunto com o princípio da mediação, constituirá futuramente a base da teoria histórico-cultural.

\subsubsection{Segundo momento. Palavra-chave: INSTRUMENTO}

Textos produzidos entre 1929 e 1930

O segundo momento do percurso através das obras do autor foi aqui sintetizado pela palavra Instrumento. Isso se deve ao fato de que, nesta fase, o método instrumental adquire contornos claros na produção do autor, e os conceitos de ferramentas e signos são 
aprofundados. A definição de método instrumental será aprofundada oportunamente; apenas como referência inicial, assinala-se que o método instrumental é uma definição de Vigotski fundamentada no que ele concebe como o caráter instrumental da psique, que se constitui e funciona a partir de instrumentos artificiais adquiridos através da interação social, e cujo maior exemplo é a linguagem. Portanto, o momento Instrumento tem como marca a formação artificial da dinâmica psíquica a partir de fora, do social, o que transforma radicalmente os reflexos inatos, de maneira que será impossível distingui-los dos reflexos socialmente construídos, a não ser através de abstrações teóricas.

Foram selecionados para representar este momento seis textos escritos entre 1929 e 1930, período de produção particularmente profícua de Vigotski.

O primeiro texto é o Manuscrito de 1929 (VIGOTSKI, 1929/2000). Neste texto, Vigotski esboça o conceito de funções psíquicas superiores, que seria posteriormente desenvolvido em seu livro História do desenvolvimento das funções psíquicas superiores, de 1931, bem como outros conceitos originais, como a concepção sistêmica do cérebro, a relação entre estímulos instrumentais, sinais e cérebro, além de outros conceitos que infelizmente Vigotski não teria oportunidade de aprofundar posteriormente (PUZIREI, 2000).

O segundo texto de 1929 é O problema do desenvolvimento cultural da criança (VYGOTSKI, 1929/2008; VYGOTSKY, 1929/2010), artigo que integra uma série de três artigos sobre o problema do desenvolvimento cultural da criança, sintetizando algumas das pesquisas de Vigotski, Luria e Leontiev, e abordando a relação entre os fatores biológicos e sociais no desenvolvimento da criança.

O terceiro texto estudado é $O$ método instrumental em psicologia (VIGOTSKI, 1930c/2004). Trata-se de uma conferência proferida em 1930 e obtida no arquivo pessoal do autor, portanto, não publicada em vida, mas apenas na ocasião da edição de suas obras completas em russo. Neste texto, apresentado na forma de 24 tópicos, Vigotski faz uma síntese do papel do conceito de instrumento no desenvolvimento humano, enfocando objetivamente a ação do cérebro no comportamento humano.

O quarto texto analisado foi publicado em 1930, desconhecendo-se a data em que foi escrito; trata-se de A psique, a consciência, o inconsciente (VIGOTSKI, 1930b/2004), onde os conceitos que lhe dão título são debatidos e articulados com os pressupostos da psicologia histórico-cultural, de forma a defender a indissociabilidade entre fenômenos biológicos e psíquicos na explicação da consciência humana. 
O quinto texto é Sobre os sistemas psicológicos (VIGOTSKI, 1930a/2004), onde o autor descreve o processo de internalização das relações interpsicológicas que então se tornam intrapsicológicas, enfatizando que tal processo é social em sua origem, e não depende de um suposto desenvolvimento cerebral, defendendo que "a evolução biológica do homem já tinha terminado antes que começasse seu desenvolvimento histórico" (p.115), bem como esclarecendo que as funções psicológicas superiores não têm uma relação direta com localizações cerebrais, ainda que sejam um produto das estruturas cerebrais. As ideias que Vigotski desenvolve sobre o cérebro neste texto são fundamentais para compreender sua visão sobre a base material da consciência, e podem ser sintetizadas na seguinte passagem:

Damo-nos conta cada vez mais da manifesta diversidade e do caráter inconcluso das funções cerebrais. É muito mais correto admitir que o cérebro encerra enormes possibilidades para o aparecimento de novos sistemas. Essa é a principal premissa. (p.130)

O sexto e último texto que integra o momento Instrumento é o livro escrito em parceria com Luria intitulado Estudos sobre a história do comportamento: símios, homem primitivo e criança (VYGOTSKY; LURIA, 1930/1996). Neste livro são reunidos dois capítulos escritos por Vigotski (Comportamento do macaco antropóide e $O$ homem primitivo e seu comportamento) e um capítulo escrito por Luria (A criança e seu comportamento). Aqui, Vigotski se afasta de forma definitiva do conceito de reflexo condicionado de Pavlov e se acerca ainda mais dos estudos dos gestaltistas Köhler e Buhler, que exerceram forte influência em sua obra - contudo, como lhe era característico, através de uma análise crítica dos conceitos gestaltistas (KNOX, 1996).

Muito mais caracterizado como uma superação, no sentido marxista do termo, do que como uma ruptura com os conceitos reflexologistas e gestálticos, os conceitos da atividade instrumental tomam forma definitiva neste segundo momento aqui evidenciado. Pode-se notar ainda que o tema cérebro/base material da consciência é claramente abordado por Vigotski nesta fase, o que torna a leitura destes textos especialmente importante para o intuito desta tese. 


\subsubsection{Terceiro momento. Palavra-chave: FUNÇÕES PSICOLÓGICAS SUPERIORES}

Textos produzidos entre 1931 e 1933

Segue-se o terceiro momento didaticamente proposto, cuja palavra-síntese é Funções Psicológicas Superiores. A escolha deste nome deve-se ao enfoque do autor no estudo do desenvolvimento de funções especificamente humanas, como a linguagem, o pensamento conceitual e as emoções, onde a discussão do papel do cérebro neste desenvolvimento é abordado. Este terceiro momento abrange o período de 1931 a 1932, e pode ser subdividido em dois submomentos.

O submomento inicial tem como principal obra o livro de 1931 História do desenvolvimento das funções psíquicas superiores (1931/2000). Esta obra pode ser considerada a culminação dos estudos anteriores de Vigotski sobre a função instrumental da psique, no qual ele analisa o surgimento das funções psicológicas superiores articulado ao desenvolvimento da linguagem enquanto instrumento por excelência do pensamento humano.

Compõem ainda este submomento inicial dois capítulos da Psicologia educacional/paidologia do adolescente: o capítulo 10, O desenvolvimento do pensamento do adolescente e a formação de conceitos (VYGOTSKI, 1931a/1997) e o capítulo 11, Desenvolvimento das funções psíquicas superiores na idade de transição (VYGOTSKI, 1931b/1997), ambos de 1931, bem como o texto O primeiro ano, de 1932 (VYGOTSKI, 1932/1997). Os textos sobre adolescência tratam da passagem do pensamento por complexos ao pensamento conceitual, e o texto sobre o primeiro ano da criança enfoca, entre outros aspectos, a articulação entre o desenvolvimento neurológico e as primeiras relações sociais da criança.

O submomento final é formado pelo texto Psicologia das emoções (VIGOTSKY, 1931/2004; VYGOTSKY, 1931/1999), onde Vigotski teoriza sobre a base biológica das emoções, articulando-as com a filosofia de Espinosa. Assim como História do desenvolvimento das funções psíquicas superiores (VYGOTSKI, 1931/2000), trata-se de um texto de fôlego, mas que infelizmente não pode ser concluído por Vigotski. Neste texto, Vigotski faz uma discussão intensa sobre a teoria James-Langue acerca das emoções e sua suposta articulação com a teoria de Espinosa sobre as emoções, o que é problematizado pelo autor. A base orgânica das emoções é um dos eixos que permeiam a discussão, justificando o interesse sobre tal texto para a finalidade desta tese. 


\subsubsection{Quarto momento. Palavra-chave: CÉREBRO}

Textos produzidos entre 1932 e 1934

O quarto e último momento da análise das obras é sintetizado pela palavra Cérebro. Este momento foi assim nomeado por ser composto por obras que enfocam de forma específica as questões do desenvolvimento e deteriorização das funções cerebrais, tematizados por Vigotski no final de sua obra. Integram este momento seis textos: O problema mentecorpo (VYGOTSKY, 1932/1977), Sobre a localização (VYGOTSKY, 1934/1977), A psicologia e a teoria da localização das funções psíquicas (VIGOTSKI, 1934/2004), O problema do desenvolvimento e da desintegração das funções psíquicas superiores (VYGOTSKI, 1934/2008), O pensamento na esquizofrenia (VIGOTSKI, 1934/2008) e Para o problema da demência no Mal de Pick (SAMUKHIN; BIRENBAUM; VYGOTSKY, 1934).

Os textos O problema mente-corpo (VYGOTSKY, 1932/1977) e Sobre a localização (VYGOTSKY, 1934/1977) são excertos dos cadernos de notas de Vigotski, sendo portanto uma sucessão de anotações que o autor provavelmente pretendia desenvolver posteriormente.

O texto A psicologia e a teoria da localização das funções psíquicas (VIGOTSKI, 1934/2004) pode ser entendido como um desenvolvimento das ideias colocadas abreviadamente em Sobre a localização (VYGOTSKY, 1934/1977). Nesse texto, Vigotski aprofunda a sua visão em relação à questão do localizacionismo, que era contrária a esse tipo de proposição, e defende o funcionamento sistêmico das funções cerebrais.

Complementar a esse enfoque do cérebro como um sistema, o texto $O$ problema do desenvolvimento e da desintegração das funções psíquicas superiores (VYGOTSKY, 1934/2008) explora a questão, já anunciada por Vigotski em obras anteriores, do sentido contrário do desenvolvimento e da desintegração das funções psíquicas. Trata-se de uma conferência proferida pelo autor, o que justifica a exposição sintética das ideias principais.

No texto O pensamento na esquizofrenia (VIGOTSKI, 1934/2008) Vigotski aprofunda sua proposição de que a esquizofrenia e o pensamento conceitual na adolescência guardam similaridades no que se refere aos processos de desenvolvimento e desintegração. 
Por fim, o texto Para o problema da demência no Mal de Pick (SAMUKHIN; BIRENBAUM; VYGOTSKY, 1934) resulta de uma pesquisa desenvolvida por Vigotski com seus colaboradores Samukhin e Birenbaum.

No próximo capítulo, é feita uma apresentação resumida dos principais conceitos discutidos por Vigotski em cada um dos textos selecionados. Sempre que seja pertinente, alguns desses tópicos poderão ser discutidos neste item. Contudo, a discussão será aprofundada no capítulo que segue o da apresentação dos textos, onde se procura dar um enfoque global aos temas aqui apresentados em subdivisão didática, unindo-os num todo conclusivo e buscando-se extrair daí as principais conclusões desta tese. 


\subsection{Reflexo e consciência}

$O$ reflexo é um conceito abstrato: metodologicamente tem grande valor mas não pode se converter no conceito principal da psicologia como ciência do comportamento do homem, porque esse comportamento não constitui de forma alguma um saco de couro cheio de reflexos nem seu cérebro é um hotel para os reflexos condicionados que casualmente se alojam nele.

(Vigotski $\left.{ }^{26}\right)$

\subsubsection{Os métodos de investigação reflexológicos e psicológicos (1924)}

Inicia-se o percurso pelas obras do autor a partir do texto baseado na comunicação inaugural de Vigotski no Segundo Congresso de Psiconeurologia de toda a Rússia (1924) e publicado posteriormente em 1926, intitulado Os métodos de investigação reflexológicos e psicológicos. Este texto merece destaque não somente por sua importância histórica, mas pelo fato de apresentar, ainda que de forma incipiente, os principais fundamentos que caracterizariam a obra vigotskiana, ou seja, a reafirmação da importância do estudo da consciência e a crítica ao idealismo da psicologia pretensamente materialista da época, caracterizada pela superficialidade equivocada na abordagem dos princípios teóricos do marxismo.

Vigotski faz no texto uma defesa veemente do estatuto da consciência como objeto de estudo da psicologia, criticando o fato da mesma estar sendo excluída da

\footnotetext{
${ }^{26}$ In: A consciência como problema da psicologia do comportamento (VIGOTSKI, 1924-1926/2004).
} 
investigação psicológica pela abordagem reflexológica de Pavlov e Bekterev, que até então pareciam ser as únicas opções disponíveis em direção à construção de uma psicologia calcada em princípios materialistas. Vigotski defende que uma psicologia materialista não deveria abrir mão de seu principal objeto de estudo e do que caracteriza o humano, que é a consciência. Para Veresov (1990, p.109), a criação de uma "teoria objetiva da consciência humana" era um problema central para Vigotski, e muitos dos seus futuros conceitos trazem indícios desta preocupação fundamental do autor.

Tal apontamento é decisivo, pois declara desde o princípio a posição que Vigotski tomava contra o reducionismo da psique à neurofisiologia como saída para uma abordagem materialista, advertindo que o fato de embasar a psicologia humana na filosofia marxista não significava reduzi-la ao estudo neurofisiológico de forma isolada. Para Vigotski, a tarefa de estudar o comportamento humano era de imensa complexidade face à limitação da metodologia reflexológica baseada no condicionamento reflexo, disparidade que aumenta na medida em que se caminha dos fenômenos psíquicos primários para os mais complexos ou tipicamente humanos.

Vigotski distingue a necessidade da ampliação da metodologia reflexológica e sua fusão com a então denominada psicologia experimental ou empírica, que utilizava o método introspectivo de investigação, baseado no interrogatório ${ }^{27}$ do sujeito acerca das suas percepções, o que era alvo de duras críticas por parte dos reflexologistas e recusado por ser considerado um método subjetivo, típico da abordagem idealista de Wundt e seu discípulo Tchelpanov. Vigotski não critica a utilização do interrogatório em si, utilizando um argumento baseado no conceito de pensamento como reflexo parcialmente inibido proposto por Sechenov, que afirmava que, apesar de não se manifestar externamente, o pensamento existe objetivamente (VIGOTSKI, 1924-1926/2004). Esse tipo de argumentação é comumente utilizado por Vigotski em toda a sua obra, e é característico da sua forma dialética de defender ideias e da utilização dos princípios do materialismo histórico dialético, pois expõe a contradição inerente à crítica dos reflexologistas ao estudo da consciência. Assim, Vigotski questiona os reflexologistas se a palavra não pronunciada deixaria de ser um reflexo

\footnotetext{
${ }^{27}$ É interessante observar que algumas pesquisas atuais em neurociência utilizando instrumentos de exame do estado cerebral como o eletroencefalograma (EEG) ou até mesmo a ressonância magnética funcional (fMRI), para investigar estados cerebrais relacionados a determinadas ações, utilizam como fonte de informação o relatório dos indivíduos examinados.
} 
se permanecesse apenas pensada, indagando onde estaria o limite entre pronunciá-la ou não. Em conclusão, Vigotski (ibidem, p.11) afirma:

Portanto, ou renunciamos a estudar o comportamento da pessoa em suas formas mais transcendentais, ou necessariamente teremos que introduzir em nossos experimentos o controle desses reflexos não manifestados. A reflexologia é obrigada a também levar em conta os pensamentos e a totalidade da psique se quiser compreender o comportamento.

É importante esclarecer que Vigotski não faz uma defesa do método introspectivo, mas sim um questionamento quanto à rejeição da utilização do informe do sujeito, apontando justamente que o pensamento escapa à introspecção, e que o "interrogatório não se separa do experimento, e deve ser revisto, de forma a tornar-se um experimento científico rigoroso e exato" (idem, ibidem, p.16). Certamente, Vigotski utilizou a exclusão do informe experimental como mais um argumento apontando para o idealismo presente na reflexologia, sua contradição fundamental. Vigotski deixa claro que a reflexologia e a psicologia deveriam se unir, uma vez que ambas as ciências têm o mesmo objeto, defendendo que a integração de ambas "não apenas é necessária, mas frutífera" (idem, ibidem, p.26).

O conceito de reflexo aqui utilizado por Vigotski é muito próximo do conceito reflexológico, sendo um dos conceitos mais circulantes no meio científico em sua época, e não deve ser confundido com o conceito de reflexo psíquico da realidade proposto por Lenin. Vigotski está se referindo aos atos reflexos, ou seja, às reações à excitação do sistema nervoso. Nessa linha, conceitua consciência como um "mecanismo de transmissão entre sistemas de reflexos" (idem, ibidem, p.15). Reflexos que surgem em resposta a excitantes criados pelo homem são a base da consciência e "servem de fundamento para a comunicação social e para a coordenação coletiva do comportamento, o que indica, entre outras coisas, a origem social da consciência" (idem, ibidem, p.17), de acordo com Vigotski.

Observe-se que essa definição de consciência, ainda que aparentemente reduzida a uma base neurofisiológica, vai além do simples sistema de arco-reflexo, assemelhando-se mais um princípio articulador e organizador dos reflexos, tendo afinidade com as teorias gestaltistas da psicologia estrutural, cuja influência sobre o pensamento de Vigotski foi marcante, especialmente no início de sua obra. É interessante notar que o aspecto neurofisiológico como princípio explicativo da consciência é fundado em uma espécie de articulação sistêmica, não se limitando à justaposição de funções isoladas do sistema nervoso ou a áreas restritas no cérebro. Isso fica claro quando Vigotski afirma que "a consciência é 
uma atividade correlativa dentro do próprio organismo, dentro do sistema nervoso: a atividade correlativa do corpo humano consigo mesmo" (idem, ibidem, p.26).

Portanto, desde este início fica delineada a importância do conceito de consciência como fundamental na obra de Vigotski. Veresov (1990) defende que os conceitos fundamentais da teoria vigotskiana, como desenvolvimento cultural e internalização, entre outros, só fazem sentido se tomados em referência ao conceito de consciência.

É interessante notar também a ênfase posta pelo autor na origem social da consciência, colocada como resultante dos estímulos sociais provenientes das pessoas e que circulam através da fala (que categoriza como um sistema de reflexos de contato social e o sistema preferencial dos reflexos da consciência, refletindo a influência de outros sistemas). $\mathrm{O}$ conteúdo social, representado pela fala enquanto um reflexo, é logo destacado por Vigotski (ibidem, p.17-18).

O mecanismo da consciência de si mesmo (autoconhecimento) e do reconhecimento dos demais é idêntico: temos consciência de nós mesmos porque a temos dos demais e pelo mesmo mecanismo, porque somos em relação a nós mesmos o mesmo que os demais em relação a nós.

Pode-se notar neste trecho, de forma já elaborada e não embrionária como se poderia supor para um trabalho inicial, a gênese de sua ideia fundamental sobre a origem social do psiquismo humano, ou seja, que se constitui a partir da experiência social.

Outra afirmação fundamental desse texto é o assinalamento de que a reflexologia torna-se idealista ao limitar seu objeto de estudo aos fenômenos observáveis e excluir os fenômenos subjetivos, indo contra a unidade dos processos psíquicos e físicos, e terminando por enfatizar o paralelismo psicofísico a que, paradoxalmente, afirma contrapor-se. Como destacam Lordelo e Tenório (2010), Vigotski defendia que eliminar o estudo da consciência da investigação psicológica também era uma forma de reducionismo, uma vez que desconsiderava a consciência enquanto comportamento passível de ser observado e estudado, reiterando que tais eventos possuíam existência objetiva (ibidem, p.81). Wertsh (1988) ressalta que a alternativa proposta por Vigotski a este dilema era a ideia de que a consciência deveria ser tomada como uma organização do comportamento observável de forma objetiva, e que é imposta aos indivíduos na medida em que participam de práticas socioculturais. Desta forma, o que Wertsch chama de "critério de organização" constitui o fundamento da concepção vigotskiana de consciência, (1988, p.195-196) destacando ainda seu caráter 
dinâmico, pelo que propõe denominá-la “organização dinâmica da consciência” (1988, p.199).

Vigotski (ibidem, p.26) reitera a necessidade de uma visão monista:

Estudar o comportamento da pessoa sem a psique, como quer a reflexologia, é tão impossível como estudar a psique sem o comportamento. Não é possível, portanto, abrir espaço para duas ciências distintas.

Da análise deste primeiro texto, pode-se deduzir que sua ideia síntese é a concepção monista do fenômeno corpo-mente. Ou seja: ainda que a consciência seja um desafio enquanto objeto de estudo para uma ciência materialista, não se pode fazer concessões às concepções do paralelismo psicofísico. Embora o método de estudo da consciência proposto por Vigotski neste momento fosse basicamente reflexológico, pois é fundamentado na ação do reflexo (LORDELO; TENÓRIO, 2010), observa-se que, a despeito do uso de conceitos reflexologistas, Vigotski deixa clara a diferença entre a sua abordagem e a destes pesquisadores, pela sua firme defesa da inclusão da consciência como objeto de estudo de uma psicologia científica e materialista.

Blunden (2011) ressalta que Vigotski possuía uma formação baseada na estética, chegando através dela à psicologia, o que não era comum em um campo dominado pela reflexologia. Isso não o impedia de dominar a linguagem desse campo, como pode ser visto em sua palestra inicial em 1924. Blunden (2011) aponta que essa fala é tida como o "estágio reflexologista" de Vigotski, o que não é provável, em sua opinião, quando se considera o histórico de Vigotski. Para Blunden (2011), a definição de Vigotski sobre a consciência nesta fala, onde ressalta que se a mesma não é um reflexo não pode também ser um estímulo, mas é o mecanismo de transmissão entre sistemas de reflexos, é uma definição que evita tanto o reducionismo quanto o dualismo, concluindo Vigotski com uma pergunta retórica: é possível uma explicação científica sobre o comportamento humano que exclua a mente? Blunden (2011) destaca que Vigotski, nessa linha de raciocínio, exemplificando e mostrando que o geólogo e o historiador também não têm um acesso direto ao seu objeto de pesquisa, precisando de métodos de reconstrução, vai negando a reflexologia a partir de uma argumentação feita dentro de seu próprio enquadramento teórico. Ou seja, sem discutir a colocação de que "tudo é reflexo", Vigotski vira os conceitos e métodos da reflexologia contra ela mesma, segundo Blunden (2011), pela aplicação do método da crítica imanente, proposto por Hegel e aplicado por Marx na escrita de $O$ Capital. De acordo com esse método, 
a crítica não se opõe a um sistema de ideias: pelo contrário, entra dentro dele e o questiona em seus próprios termos para trazer à luz suas contradições internas e conduzi-lo à própria negação.

Veresov (2011), no entanto, discorda de Blunden (2011), afirmando que há sim um estágio reflexologista no desenvolvimento do pensamento de Vigotski. Para tanto, cita como argumento que Vigotski trabalhava como chefe do laboratório de psicologia em Gomel, e com isso não se podia dizer que não tinha recebido o treinamento habitual em sua época permeado pela reflexologia. Além disso, em seu livro Psicologia pedagógica, publicado em 1927 mas escrito antes de 1924, a abordagem reflexológica da consciência é bastante presente. Veresov (2011) afirma ainda que a fala de Vigotski em 1924 estava baseada na ideia de que o reflexo poderia ser aplicado como um método objetivo no estudo da consciência humana, propondo a unificação da reflexologia e da psicologia. De fato, Vigotski deixa isso claro ao definir a consciência como sendo "o reflexo dos reflexos" (VIGOTSKI, 1924, p.25). Em vista desta crítica de Veresov (2011), reflete-se aqui que pretender, como Blunden (2011) parece fazer, que Vigotski estivesse de certa forma não contaminado pelo pensamento reflexologista de sua época é uma concepção a-histórica, e talvez influenciada por certa idealização que envolve o surgimento de Vigotski no cenário da psicologia, como comentado por Van der Veer e Valsiner (2001). Em todo caso, tanto Veresov (2011) quanto Blunden (2011) não parecem discordar de que o conceito apresentado por Vigotski sobre consciência não era simples, como não é até hoje, carregando em si a pretensão de unir o cérebro dos reflexologistas com a mente dos funcionalistas, e deixando claro, isso sim, que tal questão não poderia ser abordada de maneira fecunda fora de um campo conceitual monista e materialista. 


\subsubsection{A consciência como problema da psicologia do comportamento (1925)}

A questão da consciência seria mais extensamente discutida por Vigotski no texto A consciência como problema da psicologia do comportamento, de 1925, publicado no mesmo ano em uma coletânea coordenada por Kornilov sobre psicologia e marxismo ${ }^{28}$. Neste texto, pode-se observar o esforço de Vigotski no sentido de realizar uma análise metodológica do conceito de consciência, tanto que $\operatorname{Sirgado}^{29}$ (1990) o considera, fazendo coro com Davidov e Radzikhouvsky (apud SIRGADO, 1990), um trabalho metodológico, assim como seu texto posterior, O significado histórico da crise na psicologia, de 1927, revelando sua elaboração das bases conceituais da nascente psicologia histórico-cultural. Veresov (1999, p.108) afirma que no período de 1924 a 1927 Vigotski teve como foco em seu trabalho o estudo da consciência, o que pode ser sintetizado na fórmula "a consciência e a estrutura do comportamento humano", sendo que este artigo é o marco deste trabalho, que pode ser caracterizado, ainda na opinião deste comentarista, como um fundamento metodológico na obra de Vigotski. Para Veresov (1990), um aspecto não explorado no estudo deste artigo de Vigotski é o fato de que o autor, ao propor a fórmula "consciência e estrutura do comportamento", além de uma teoria sobre o problema também apresenta uma hipótese experimental sobre o mesmo, sem o que seria impossível, segundo Vigotski, realizar uma revisão crítica do conhecimento científico acumulado na área (VIGOTSKI, 1925/2004). Veresov (1990) defende que, apesar da primeira parte do artigo ser voltada à teoria dos reflexos, o principal objetivo do mesmo era enfocar o problema da consciência enquanto estruturante do comportamento humano. Lordelo e Tenório (2010) apontam que, em relação ao texto anterior (a comunicação Os métodos de investigação reflexológicos e psicológicos, de 1924), Vigotski abandona a tentativa de utilizar os conceitos do método reflexológico para abordar o problema da consciência, enfatizando a necessidade de criar uma nova metodologia para isso.

\footnotetext{
${ }^{28}$ Veresov (1990) enfatiza que este texto não é a transcrição da palestra inicial feita por Vigotski em 1924 no Segundo Congresso de Psiconeurologia de Toda a Rússia, como foi apontado por Cole em 1979. Na verdade, a palestra de 1924 serviu de base para o artigo Os métodos de investigação reflexológicos e psicológicos, publicado em 1926 e discutido no item anterior.

${ }^{29}$ Trata-se de Angel Pino Sirgado. Em alguns textos, o nome do autor aparece ora como Sirgado (SIRGADO, 1990; 2000) ora como Pino $(2002 ; 2005)$
} 
Neste texto, Vigotski (1925/2004) trata da natureza psicológica da consciência. Aponta inicialmente que o problema da consciência é menosprezado pela ciência psicológica do seu tempo. Critica a tentativa de a reflexologia propor princípios explicativos universais, que abranjam tanto o comportamento animal quanto humano, bem como a negação da consciência, pela tentativa de construção de uma psicologia que ignore este conceito, equiparando a psicologia humana à psicologia animal. Como no primeiro texto, seu principal argumento é que excluir a consciência como objeto de estudo reforça justamente o dualismo da psicologia, pois presume o estudo de uma psicologia pura e abstrata, negando assim a principal premissa da reflexologia, ou seja, "a possibilidade de explicar todo comportamento humano sem recorrer a fenômenos subjetivos" (idem, ibidem, p.59). Para Sirgado (1990), Vigotski lança neste texto as bases metodológicas para o estudo da consciência como objeto da psicologia, rejeitando as várias interpretações conflitantes sobre o conceito que eram presentes em sua época.

Segundo Veresov (1990), Vigotski pretendia neste artigo combinar a abordagem reflexológica, entendida como um método científico objetivo, com a psicológica, caracterizada como uma abordagem subjetiva do mundo interno do indivíduo. Nesse sentido, apresenta o conceito de inibição central proposto por Sechenov como responsável pela formação da subjetividade do indivíduo, bem como a consciência como constituída por reflexos inibidos. Argumentando que os reflexos inibidos existem tanto quanto os completos, Vigotski questiona a proposta de eliminá-los do estudo objetivo da consciência, reiterando a crítica à psicologia de seu tempo em eliminar a consciência como objeto de estudo.

Mais uma vez, a noção do sistema nervoso como um princípio organizador é enfatizada, quando Vigotski (ibidem, p.61) afirma que

o trabalho de cada órgão, seu reflexo, não é algo estático, mas somente uma função do estado geral do organismo. O sistema nervoso funciona como um conjunto [...] que deve servir de base para a doutrina do comportamento.

Vigotski condena a recorrência ao conceito de reflexo como explicação universal para todos os fenômenos, defendendo que, ao invés do estudo de reflexos isolados, estude-se o comportamento e seus mecanismos, bem como a consciência em uma linguagem objetiva. Para ele, a consciência não existe como categoria ou procedimento especial da existência, sendo uma estrutura complexa do comportamento ou sua duplicação. 
Vigotski aprofunda aqui a questão da importância da experiência social e histórica do homem. Aponta que o comportamento animal compõe-se de dois grupos de reações: reflexos não condicionados (inatos) e condicionados (adquiridos). No homem, a situação é radicalmente diferente, pois a experiência histórica herdada norteia seu comportamento. A experiência social, ou o componente social do comportamento, o diferencia do animal, pois o homem não se adapta passivamente ao meio, mas antes o adapta a si. Citando o exemplo de Marx sobre a abelha e a aranha, aponta que o homem concretiza o que projetou anteriormente, e não apenas segue instintos. Sua ação existe duas vezes, como projeto idealizado e como trabalho executado, o que chama de comportamento de experiência duplicada, e afirmando que o comportamento humano pode ser expresso pela fórmula experiência histórica experiência social - experiência duplicada.

Neste texto, Vigotski aborda diretamente a questão do cérebro e sistema nervoso central. Para ele, o cérebro teria a função de integrar reflexos vindos de pontos distantes: “o sistema nervoso é integrado, na verdade, pela totalidade do indivíduo" (ibidem, p.68), reforçando sua concepção sistêmica do sistema nervoso.

É importante enfatizar que o foco principal do texto é a defesa da consciência como objeto concreto de estudo, o que mais tarde seria discutido em termos epistemológicos por Vigotski no seu texto sobre a crise da psicologia, de 1927. Lordelo e Tenório destacam uma passagem deste texto em que Vigotski defende de forma veemente tal objetivo: "ou os fenômenos psíquicos existem e então são materiais e objetivos, ou não existem e não podem ser estudados. É impossível qualquer ciência só sobre o subjetivo, sobre o que parece, sobre fantasmas, sobre o que não existe" (VIGOTSKI, 1927, apud LORDELO; TENÓRIO, 2010, p.83, grifado no original).

\subsubsection{Prólogo à versão russa do livro de E. Thorndike, "Princípios de ensino baseados na psicologia" (1926)}

Nesta introdução, Vigotski define como ideia chave da nova psicologia (que então se constituía) a "psique e comportamento humanos como um sistema de reações do 
organismo aos excitantes externos enviados pelo meio ambiente e pelos excitantes internos que surgem no próprio organismo ${ }^{30 "}$ (VYGOTSKI, 1926/1991, p.145). Assim, define o comportamento como um sistema de reações a excitações internas e externas, e a psique como um sistema que articula formas de comportamento complexas.

Vigotski classifica o livro de Thorndike como sendo de transição, necessário enquanto ainda não havia uma referência bibliográfica mais adequada aos objetivos da nova psicologia. Refere que falta ao livro a reafirmação de uma teoria agregadora das dimensões biológica, social e psicológica sobre o comportamento, apesar de reconhecer que tal teoria estaria presente de forma não manifesta. Afirma que

a nova psicologia parte da ideia da ligação indissolúvel que une a psique com os demais processos vitais do organismo, buscando o sentido, o significado e as leis do desenvolvimento psíquico justamente na integração da psique no conjunto das demais funções vitais do organismo ${ }^{31}$ (ibidem, p.151).

Vigotski faz uma fundamentação darwiniana da psique como resultante de uma adaptação biológica do ser humano ao meio, expressa através das condutas inteligentes. Como as mudanças orgânicas e no meio ambiente são lentas, o organismo possui um procedimento mais rápido e flexível de responder às variações do meio, que é a mudança funcional do órgão resultante da experiência individual de cada ser humano. As adaptações biológicas podem ser classificadas em hereditárias (adaptações estruturais do organismo e do comportamento reflexo ou instintivo) e não hereditárias (adaptações funcionais e do comportamento inteligente). A reação é, para Vigotski, a base do comportamento humano - por maior que seja a sua complexidade, os comportamentos complexos constroem-se sobre a base dos comportamentos inatos ou reflexos, ou seja, incondicionados, num processo constante.

O comportamento do homem revela-se a nós não somente como um sistema estático de reações já elaboradas, mas sim como um processo ininterrupto de aparecimento de novas conexões, de estabelecimento de novas relações de dependência, de elaboração de novos super-reflexos e, ao mesmo tempo, de interrupção e destruição

\footnotetext{
${ }^{30}$ No original: "considerar la psique y el comportamiento humanos como un sistema de reacciones del organismo a los excitantes externos enviados por el medio ambiente y por los excitantes internos que surgen em el propio organismo."

${ }^{31}$ No original: "La nueva psicología parte de la idea de la indisoluble ligazón que une a la psique con los restantes processos vitales del organismo, buscando el sentido, el significado y las leyes de desarrollo psíquico precisamente en la integración de la psique en el conjunto de las demás funciones vitales del organismo."
} 
das conexões anteriores, de desaparecimento de reações prévias [...] como um processo dinâmico de luta entre o homem e o mundo e dentro do próprio homem ${ }^{32}$. (ibidem, p.157)

Assim, Vigotski reafirma o caráter socialmente condicionado das reações humanas, pois a experiência individual se forma e organiza como uma cópia da organização de diferentes elementos do meio que atuam como excitantes, deixando implícitas nesta experiência as condições que a conformaram.

Sob este ponto de vista, o cérebro/base material da consciência se desenvolveria e modificaria como uma adaptação funcional ao ambiente e à experiência humana acumulada, num processo dialético constante. Merece destaque a ênfase que Vigotski confere a uma concepção monista do ser humano, na qual há uma integração completa e indissociável entre os aspectos psíquicos e orgânicos. O comportamento é explicado como uma complexificação crescente de reações constituídas sobre reações.

Tem-se então, neste primeiro momento da obra vigotskiana, uma colocação vigorosa a favor da consciência como objeto de estudo da psicologia, sem com isso abdicar de uma fundamentação materialista deste objeto. Também fica clara a visão sistêmica de Vigotski sobre a ação do sistema nervoso e do organismo humano como um todo. Ainda que tais ideias estivessem em estágio embrionário, Vigotski afirma a importância da experiência social na constituição do psiquismo humano. No segundo momento, que vem a seguir, buscase acompanhar a trajetória de Vigotski através da construção de uma fundamentação teórica e de uma metodologia científica e materialista para consolidar as ideias aqui esboçadas.

\footnotetext{
${ }^{32}$ No original: "el comportamiento del hombre se nos revela no sólo como un sistema estático de reacciones ya elaboradas, sino como un processo ininterrumpido de aparición de nuevas conexiones, de estabelecimiento de nuevas relaciones de dependencias, de elaboración de nuevos superreflejos y al mesmo tiempo de interrupción y destrucción de las conexiones anteriores, de desaparición de reacciones previas [...] como un processo dinámico y dialéctico de lucha entre el hombre y el mundo y dentro del proprio hombre." p.157.
} 


\subsubsection{Psicologia pedagógica (1926)}

Segundo Van der Veer e Valsiner (2001), este foi um dos poucos livros que Vigotski veria editado em vida. Psicologia pedagógica tem como data de publicação 1926, mas provavelmente foi escrito antes, uma vez que Vigotski teria apontado sua autoria já em 1924, além dos pontos de vista defendidos aqui divergirem de textos que Vigotski escreveu em 1926.

Como num manual, Vigotski faz um trabalho de síntese entre diversas correntes psicológicas, incluindo a reflexologia e a psicanálise (citada de forma pouco crítica, diversamente dos seus escritos posteriores), no sentido de explorar suas possíveis contribuições à psicologia da nova sociedade socialista para cuja construção visava contribuir, como base para um material teórico voltado à formação de professores. A abrangência do texto é significativa, enfocando aspectos do comportamento, atenção, memória, educação para o trabalho, emoções, inteligência, educação estética, sexualidade e outros tópicos considerados importantes para a formação dos educadores.

No texto, Vigotski defende a teoria dos reflexos condicionados de Pavlov como solução para a crise na psicologia, tema que trataria em outras oportunidades também. No entanto, como lembram Van der Veer e Valsiner (2001), esta solução não poderia ser adotada universalmente no atual momento, uma vez que Vigotski reconhecia que a teoria dos reflexos não era suficiente para explicar comportamentos mais complexos, apesar de defender que o comportamento poderia ser explicado em termos de encadeamento de reflexos.

Os fundamentos biológicos da psicologia como base do comportamento são bastante enfatizados por Vigotski neste texto. Em todos os temas abordados, o autor dedica uma explicação detalhada da relação destes com os fundamentos biológicos - por exemplo, bases biológicas da atenção, da memória, da emoção, da inteligência, entre outros. A ênfase no aspecto biológico também pode ser lida como uma reação à psicologia introspectiva, particularmente em seu aspecto dualista, que era a fonte objetiva das críticas de Vigotski. Assim, concordava que, "em vez de uma ciência sobre os fenômenos psíquicos, hoje a psicologia começa a assumir a forma de uma nova ciência, que os cientistas americanos definem como ciência do comportamento dos seres vivos" (VIGOTSKI, 1926/2010, p.6). A psicologia, portanto, se torna ciência biológica ao estudar a adaptação do organismo ao meio, e vê o "comportamento como uma das formas fundamentais de adaptação de um organismo 
vivo ao meio" (idem, ibidem, p.6).Interessante destacar nesta definição o enfoque na interação indivíduo/meio que a definição biológica de comportamento traz. Tal conceito, no entanto, é desde o inicio ampliado por Vigotski para incluir a característica social do comportamento humano: "contudo, o comportamento do homem se processa nos complexos limites do meio social" (ibidem, p.6). O meio social se torna o fator mais importante, de acordo com Vigotski, e esta ideia é enfatizada em toda a obra, concluindo que "a psicologia estuda o comportamento do homem social e as leis da mudança desse comportamento" (ibidem, p.6-7). Para esta nova ciência, portanto, a metodologia não pode ser o informe introspectivo, mas o método experimental, uma vez que ela se caracteriza por seu materialismo, objetivismo, método dialético e fundamento biossocial, segundo o autor.

A reação, segundo Vigotski, é a unidade básica do comportamento, e é definida como produzida pela relação entre o organismo e o meio. Vigotski conceituou o funcionamento do comportamento como um processo trifásico da reação, nos momentos de recepção, processamento e resposta ao estímulo. Observando que o reflexo é a reação nos animais dotados de sistema nervoso, Vigotski esclarece que opta pelo termo reação por considerar que o conceito de reflexo ficava restrito à fisiologia do sistema nervoso, ao passo que o conceito de reação podia iluminar o comportamento humano em sua relação com o meio e sua função adaptativa. Os reflexos hereditários ou incondicionados são o grupo principal de reações do recém-nascido, segundo Vigotski, que também conceitua os instintos como formas complexas de comportamento hereditário, reflexos esses que dotam a criança dos elementos que irá necessitar até para as formas de comportamento mais complexas: “a criança não é uma folha de papel em branco, mas uma folha preenchida inteiramente pelos vestígios da experiência biologicamente útil dos antepassados" (ibidem, p.27). Elaborando os reflexos incondicionados herdados, portanto, o indivíduo adapta-se, sendo o meio um fator decisivo neste processo. No entanto, o caráter histórico é enfatizado pelo autor: "todos nós usamos na ciência, na cultura e na vida uma enorme quantidade de experiência que foi acumulada pelas gerações anteriores e não se transmite por herança física" (ibidem, p.42). Destaca ainda que os conceitos de reação e reflexo são abstratos, pois não se encontram de forma isolada, estando em "ligação recíproca permanente e indissolúvel" no ser humano (ibidem, p.44).

Mesmo nesse período inicial, a perspectiva social sobre o comportamento humano permeia o pensamento do autor sobre o comportamento baseado nas reações. Como apontam 
Van der Veer e Valsiner (2001), Vigotski defende que relativamente ao comportamento humano devem ser considerados as reações inatas e os reflexos condicionados, bem como as experiências histórica, social e duplicada (ou seja, construída mentalmente antes de concretamente, portanto, reações a estímulos internos surgidos como reações a estímulos externos). Vigotski também apontou que a automatização de determinados comportamentos não torna menos importante a reação humana, e, pelo contrário, é uma condição psicológica para que possam surgir tipos superiores de atividade, uma vez que dispensa o sistema nervoso de focalizar a atenção em atividades cotidianas como caminhar, por exemplo. Para o autor, a automatização é uma lei cujo fundamento "reside na específica plasticidade da nossa massa nervosa", uma protolinguagem de reações experimentadas que predispõe a sua repetição (ibidem, p.84).

O fato de Vigotski reconhecer a importância fundamental do meio não fazia com que o homem fosse visto como um autômato. Para ele, não se poderia distinguir de forma absoluta meio externo e indivíduo: "o meio não é algo absoluto, exterior ao homem. Não se consegue nem sequer definir onde terminam as influências do meio e começam as influencias do próprio corpo" (ibidem, p.71). Argumentava que os reflexos são estabelecidos por um processo bilateral, onde meio e indivíduo exercem mútua influencia, e daí "o estabelecimento das reações é um resultado da luta entre organismo e meio" (ibidem, p.117).

Em relação à possibilidade de conciliação entre hereditariedade e meio pela teoria do reflexo condicionado, Vigotski ressalta que não trata da hereditariedade de forma limitada ao círculo familiar, mas sim a das "formas mais amplas de herança da experiência de toda a humanidade" (ibidem, p.421), sendo que essa não é estagnada e muda constantemente. Portanto, para Vigotski, assim como o humano dispõe de todos os movimentos que irá necessitar durante a vida desde o berço, nenhum deles permanecerá da mesma forma como os herdou. Vigotski reconhecia que hereditariedade e ambiente são teses opostas, mas afirmava que a contradição não existe só no pensamento mas na vida, e desta contradição surge a educação. O caráter, portanto, não surge das propriedades orgânicas herdadas nem das influências sociais do meio isoladamente, mas "de um choque contraditório de umas contra outras e da transformação dialética do comportamento hereditário em comportamento individual" (ibidem, p.423).

É interessante destacar também a referência feita por Vigotski à questão do movimento: "todos os fenômenos psíquicos que ocorrem no organismo podem ser estudados 
do aspecto do movimento" (ibidem, p.6). A influência do movimento no psiquismo foi estudada por Munsterberg, cujo trabalho é citado por Vigotski (MUNSTERBERG, 1910, apud VIGOTSKI, 1926/2010). Esse destaque é feito por Vigotski em relação ao papel secundário atribuído ao corpo pelo funcionalismo de base introspectiva e dualista. $\mathrm{O}$ movimento é a forma mais simples de reação, movimentos que são oriundos de ou vão no sentido de algo. Vigotski afirma que "as formas mais sutis do psiquismo são sempre acompanhadas dessas ou daquelas reações motoras", destacando o papel do movimento na percepção de objetos: "nenhuma percepção ocorre sem o movimento dos órgãos adaptativos" enfatizando que também o pensamento é acompanhado de movimentos inibitórios, com emissão embrionária de palavras. Entretanto, como apontam Van der Veer e Valsiner (2001), Vigotski não parece defender o fundamento motor do comportamento como princípio explicativo, alinhando ao lado desta outras hipóteses, como os processos químicos embasando o comportamento.

Em relação ao cérebro, Vigotski faz algumas referências durante a obra, principalmente ao descrever o papel do sistema nervoso central (encéfalo e medula espinal) na elaboração das reações, conceituando o córtex como uma superestrutura que serviria de receptáculo para os reflexos condicionados, funcionando como o órgão da experiência pessoal do indivíduo, enquanto a medula seria o local das reações hereditárias e reflexos incondicionados. O córtex seria uma espécie de projeção do aparelho receptor, analisando e decompondo os elementos do mundo externo no estabelecimento de vínculos com o organismo, e sintetizando-os na forma de reflexos condicionados.

Vigotski (ibidem, p.63) articula essas explicações à educação, enfatizando que “o único educador capaz de formar novas reações no organismo é a sua própria experiência [... ] a experiência pessoal do educando se torna a base do trabalho pedagógico". Para ele, subestimar a experiência do aluno ou considerá-lo um ser passivo era um erro do ponto de vista científico. Tal fato não relegava ao professor um papel menos importante para Vigotski, pois a ele caberia organizar o meio social da aprendizagem, expressando esse conceito pela formulação: “a educação se faz através da própria experiência do aluno, a qual é inteiramente determinada pelo meio, e nesse processo o papel do mestre consiste em organizar e regular o meio" (ibidem, p.67). 


\subsection{Instrumento}

O homem quer um pau, o macaco, um fruto. $\left(\right.$ Vigotski $\left.^{33}\right)$

\subsubsection{Manuscrito de 1929 (1929)}

Abre-se este segundo momento com o Manuscrito de 1929, intitulado por Puzirei, que foi responsável pela primeira publicação em russo em 1986, como Psicologia concreta do homem (VIGOTSKI, 1929/2000).

Este texto tem uma importância histórica no conjunto da obra de Vigotski, pois se trata do primeiro esboço conhecido das ideias que seriam elaboradas posteriormente de forma mais consistente em sua obra História do desenvolvimento das funções psíquicas superiores, de 1931, e que são a base da psicologia histórico-cultural. Segundo Puzirei (2000), o texto em pauta seria também a versão preliminar de um texto mais breve que o de 1931, ainda inédito sobre o tema.

Neste texto, o papel da mediação instrumental ou sinalização na psique humana é delineado com maior aprofundamento. Vigotski trabalha aqui nas bases teóricas fundamentais da psicologia histórico-cultural, estabelecendo suas teses principais, que serão apresentadas como o autor as esboçava então. Em relação aos critérios de seleção utilizados nesta tese, este texto foi escolhido por apresentar referências claras ao cérebro e seu papel no psiquismo humano. Oportunamente, o texto História do desenvolvimento das funções psíquicas superiores (1931/2000) será também apresentado e analisado dentro do percurso cronológico que aqui está sendo feito, motivo pelo qual o Manuscrito de 1929 será retomado adiante.

É preciso dizer que, dado seu caráter inconclusivo de arcabouço para futuras produções, o Manuscrito é um texto um tanto hermético, e que ainda aguarda estudos mais aprofundados. Destaca-se aqui a leitura feita por Sirgado (2000): sua comparação da tessitura do Manuscrito com os esboços de Guernica é bastante elucidativa, pois se trata da relação

\footnotetext{
${ }^{33}$ In: O problema da consciência (VIGOTSKI, 1933/2004, p.177).
} 
entre os detalhes e o todo da obra vigotskiana, uma obra que, ao contrário da de Picasso, não teve oportunidade de amadurecer. Não se furta aqui, no entanto, de realizar-se algumas aproximações.

Nesse texto, Vigotski estabelece o caráter instrumental do psiquismo humano. Fazendo uma analogia com o papel das ferramentas na transformação da natureza pelo homem, atividade que o caracteriza e que é conceituada no marxismo como trabalho, Vigotski postula que os instrumentos são a essência do intelecto humano.

A peculiaridade do psiquismo humano é resultar de uma síntese entre a evolução ou história geral e a história do homem. Devido a esta peculiaridade, as funções psicológicas básicas ou primárias, de forte componente instintivo e biológico, são transformadas, no processo de desenvolvimento cultural do homem, em funções psicológicas superiores, ou seja, tipicamente humanas. Assim, a atenção instintiva para um ruído, a memória eidética ou partindo de imagens, por exemplo, vão se transformando em atenção concentrada e mnemotécnica.

Vigotski postula a origem externa ou social da função psicológica superior, afirmando que a mesma foi uma relação social entre duas pessoas antes de se tornar função, e enuncia uma lei geral: "qualquer função no desenvolvimento cultural da criança aparece em cena duas vezes, em dois planos - primeiro no social, depois no psicológico, primeiro entre as pessoas como categoria interpsicológica, depois - dentro da criança" (ibidem, p.26). Como resume Smolka (2000, p.31), o foco da análise psicológica se inverte em relação ao enfoque tradicional: "não é o que o indivíduo é, a priori, que explica seus modos de se relacionar com os outros, mas são as relações sociais nas quais ele está envolvido que podem explicar seus modos de ser, de agir, de pensar, de relacionar-se" (grifado no original).

Sirgado (2000, p.46) reflete que a enunciação desta "lei genética geral do desenvolvimento cultural" estabelece que o social e o cultural se colocam como categorias fundamentais no pensamento do autor, ainda que Vigotski não tenha estabelecido de forma clara o significado dessas duas categorias. Sirgado realiza o exercício de esclarecer estes conceitos, para o que, defende, deve-se estabelecer em relação a qual contexto teórico são utilizados. Nessa tarefa, destaca a importância da definição de história dada por Vigotski na abertura do Manuscrito, ressaltando que é justamente a ênfase no aspecto histórico que delineia o significado dos termos social e cultural para Vigotski - no caso, trata-se do 
materialismo histórico-dialético, o núcleo duro da obra vigotskiana, segundo Sirgado (2000, p.48).

Tais relações sociais são internalizadas, passando a incorporar o modo de funcionamento da psique humana e formando a base das demais operações cognitivas. Vigotski pontua que agem de forma semelhante aos instrumentos dado seu caráter de mediação, mas como tem uma atuação psicológica, Vigotski conceitua-as como sinais. Inicialmente, o sinal/instrumento coloca-se entre o sujeito e o objeto externo, atuando como um instrumento, a partir de fora e fisicamente. A partir do momento em que essa operação é internalizada e torna-se subjetiva, o sinal se coloca entre o sujeito e sua própria memória. Assim, a principal diferença entre o sinal e o instrumento estaria no posicionamento, já que a função exercida é semelhante - enquanto o instrumento se coloca entre o sujeito e o objeto, o sinal se coloca entre o sujeito e o objeto internalizado, que é a memória ou o próprio cérebro. A relação do sujeito consigo mesmo, ou com esses conteúdos internalizados, é mediada pelo sinal, e a sua influência passa a ser psicológica, ou sobre o comportamento. Vigotski assinala que o objeto da influência do sinal (ou estímulo instrumental internalizado) é o cérebro.

Julgou-se procedente deter-se na interpretação dos dois esquemas utilizados por Vigotski para a apresentação do caráter instrumental da psique (ibidem, p.28-29). À primeira vista, tais esquemas são pouco esclarecedores - note-se, por exemplo, a coincidência do uso na literatura psicológica em português da letra "S" para abreviar as palavras "estímulo", "sujeito" e "sinal", além de se a letra inicial de "signo". É prudente esclarecer que, assim como ocorre com outros termos utilizados comumente pelo autor, Vigotski não define de forma clara os termos signo e sinal (SMOLKA, 1995), Desta forma, merecem um estudo mais detalhado, visando ampliar sua compreensão. Oliveira (2010) contribui nesse sentido, assinalando que "signos podem ser definidos como elementos que representam ou expressam outros objetos, eventos, situações" (p.31), esclarecendo ainda que Vigotski considera os signos como "instrumentos psicológicos", diferindo dos instrumentos externos ou ferramentas na medida em que são orientados para ações psicológicas em relação aos outros ou ao próprio indivíduo. Sirgado (2000) também ilumina essa questão comentando as definições que Vigotski utiliza em relação à memória natural e a artificial, em que assinala " o sinal como expressão da natureza e o signo como expressão cultural" (p.56). Em relação a sinal e signo, Sirgado (2000) aponta a característica diferencial da reversibilidade, em que "diferentemente 
do simples sinal, o signo tem a propriedade de ser reversível, ou seja, a de significar tanto para quem o recebe quanto para quem o emite" (p.59).

Ao introduzir os esquemas, Vigotski aponta a necessidade (ibidem, p.28) de diferenciar a relação imediata e a relação mediada ou mediatizada (através de sinal) com os outros, destacando que a relação imediata é impossível de se aplicar "para si”, ao contrário da relação mediada. Com isso, está dizendo que a relação de um sujeito consigo mesmo é sempre mediada pelos conteúdos internalizados das relações sociais.

A expressão "para si" alude ao terceiro momento do desenvolvimento cultural. Segundo Vigotski, os três momentos são o desenvolvimento "em si", "para outros" e "para si" 34 . Relacionando-se os três momentos do desenvolvimento cultural com o exemplo do gesto de apontar feito pela criança para a mãe, comumente utilizado por Vigotski, tem-se:

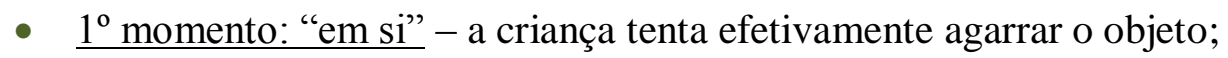

- $2^{\circ}$ momento: "para outros" - a criança tem seu gesto interpretado pela mãe como uma indicação da sua intenção de obter o objeto;

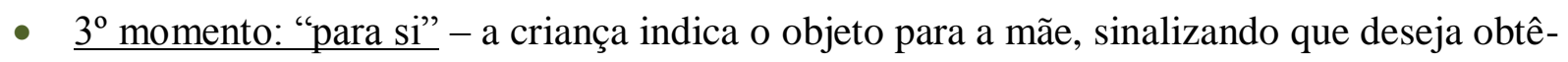
lo com a sua mediação.

O primeiro esquema se divide em três subesquemas, que são: Esquema I Instrumento, Esquema II - Sinal e Esquema III - Auto-estimulação, representados no gráfico a seguir:
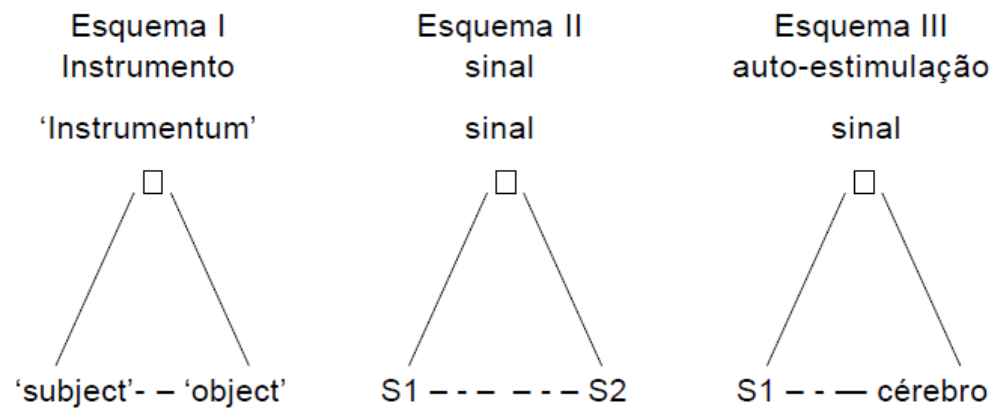

Figura 2: Esquema I - Manuscrito de 1929 (VIGOTSKI, 1929/2000)

\footnotetext{
${ }^{34}$ Estas denominações estão provavelmente relacionadas com as categorias marxistas da análise dialética.
} 
No Esquema I - Instrumento, tem-se a representação do Instrumento (Instrumentum) atuando de forma mediadora entre o Sujeito (subject) e o Objeto (object). Tal operação é externa e social, e pode ser comparada ao primeiro momento do desenvolvimento cultural no gesto de apontar ("em si"), onde a criança (Sujeito) tenta agarrar com a mão o brinquedo (Objeto) e não consegue. É necessária então a mediação de um instrumento externo, papel exercido pela mãe (Instrumento). A partir do momento em que a criança percebe que sua tentativa frustrada de agarrar o brinquedo é interpretada pela mãe como seu desejo de obter o brinquedo, após o que o entrega a ela, a criança transforma a tentativa de agarrar no gesto de apontar, através do qual consegue a mediação da mãe e consequentemente o brinquedo. Este é o segundo momento do desenvolvimento cultural no gesto de apontar ("para outros"), onde o gesto de apontar passa a ser um sinal, pois era um instrumento externo que foi internalizado. Ou seja, a tentativa de agarrar transforma-se no gesto de apontar, que se torna o Sinal ou mediação entre a criança-Sujeito e o brinquedo-Objeto, a partir da interpretação da mãe. É importante ressaltar que a criança, ao querer o brinquedo, passa então a se dirigir à mãe, e não ao brinquedo em si - a mãe, ou melhor, a interpretação da mãe é a mediação que a criança utiliza para conseguir o objeto. Não se dirigir diretamente ao objeto e sim à mãe, que sabe o que significa o gesto de apontar, é a síntese do que seria uma operação mediada internalizada. Segundo Vigotski, é com base nesse tipo de operação que o cérebro funciona, ou seja, que se constitui o psiquismo humano.

Chega-se deste modo ao que está representado no Esquema II - Sinal, onde o sinal, ou instrumento internalizado, é representado atuando como mediador interno entre dois sujeitos ( $S 1$ e $S 2$ ) em uma relação social internalizada. Isso ocorre porque a criança $(S 1)$ internalizou o gesto de apontar como um sinal, sabe que este gesto tem o significado compartilhado com a mãe (S2) de quem deseja o brinquedo, e daí sinaliza para a mãe ao invés de tentar alcançar diretamente o objeto. Estaria aqui representado o segundo momento do desenvolvimento cultural ("para outros"), onde o gesto da criança é interpretado pelo outro, no caso, a mãe.

No Esquema III - Auto-estimulação, é representado o sinal, ou instrumento internalizado, atuando como mediador entre o sujeito social internalizado a partir da própria experiência (S1) e o cérebro deste sujeito, onde o processamento destas informações ocorre. Pode-se pensar então que se trata aqui de uma operação cognitiva, a partir dos conteúdos sociais internalizados pelo sujeito em suas vivências. Esta operação corresponde ao terceiro 
momento do desenvolvimento cultural - "para si", e no exemplo do gesto de apontar corresponde ao conceito cognitivo formado a partir da interiorização que a criança $(S 1)$ sobre sua comunicação com a mãe, ou ainda sobre os conceitos envolvidos na operação toda, como apontar e mãe, entre outros.

Neste ponto da interpretação do esquema, pode-se concluir que o cérebro, segundo o que Vigotski apresenta aqui, é conceituado como o local específico onde tais operações cognitivas ocorrem, na medida em que são internalizadas a partir das experiências sociais. O sujeito internalizado $S 1$ pode ser entendido como uma conexão cerebral formada a partir de estímulos externos, ou experiências enquanto sujeito real e com outros sujeitos reais.

Vigotski (ibidem, p.29) introduz o segundo esquema, composto de dois subesquemas, Instrumento e Tarefa psicológica, observando que "a construção se diferencia da operação instrumental ${ }^{35}$ por ser de dois planos, de dois objetos”. Pode-se deduzir portanto que os dois subesquemas seguintes procuram explicitar os conceitos de operação instrumental e de construção.
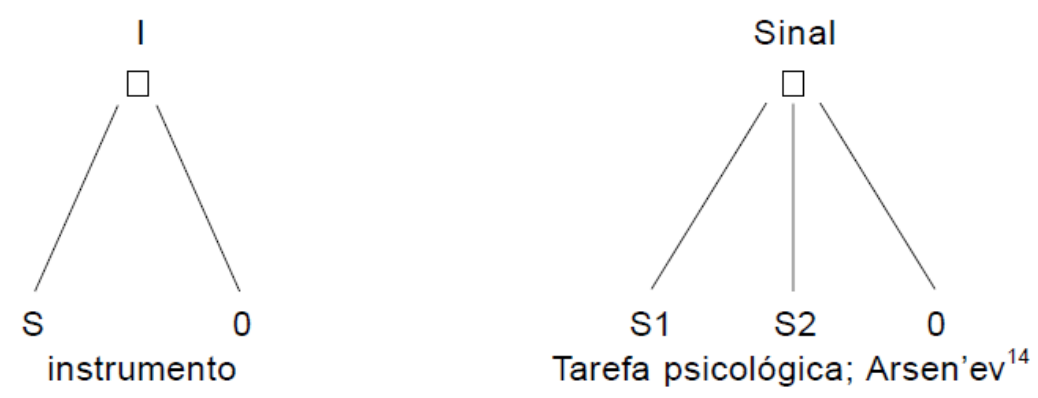

Figura 3: Esquema II - Manuscrito de 1929 (VIGOTSKI, 1929/2000)

$\mathrm{Na}$ primeira parte do esquema, no subsquema Instrumento, Vigotski representa o conceito de operação instrumental. Na segunda parte do esquema no subsquema Tarefa psicológica, Vigotski representa o conceito de construção, que envolve o sinal.

Vigotski inicia explicando o conceito de construção no segundo subesquema Tarefa psicológica, afirmando que o objeto (O) a que os sujeitos (S1 e S2) acessam através da mediação do Sinal pode ser o cérebro do outro ou o próprio cérebro do sujeito.

\footnotetext{
${ }^{35}$ Ou pensamento instrumental, um conceito de Buhler, segundo Puzirei (VIGOTSKI, 1929/2000, p.29).
} 
Ao referir-se ao nome do etnógrafo russo Arsen'ev neste esquema, Vigotski teria em mente o exemplo que utilizaria mais tarde na História do desenvolvimento das funções psíquicas superiores (1931/2000, p.78). Segundo este exemplo, os habitantes de um povoado visitado por Arsen'ev pedem que dê um recado a autoridades russas, e dão-lhe um dente de lince para que não se esqueça de dar o recado. Pode-se ver neste exemplo o embrião do conceito de memorização, que será intensivamente desenvolvido por Vigotski na História do desenvolvimento das funções psíquicas superiores (idem), e que será discutido adiante.

Por ora, cabe assinalar que Vigotski provavelmente idealizava que a introdução de um estímulo artificial (dente de lince) influenciava o processo de memória, tornando-se um sinal que "sustenta a operação, que está direcionada para o objeto. Mas seu objeto é a própria operação, o processo nervoso" (ibidem, p.30). Ou seja, o estímulo artificial (dente de lince) sustenta a operação, mas o objeto para o qual se direciona é a tarefa psicológica de memorizar - daí tornar-se um sinal, pois passa a ter um significado interno que remete à tarefa a ser realizada.

Vigotski afirma que "a construção envolve dois objetos", mas no esquema Tarefa psicológica apenas um "O" é representado - o que pode ser devido à coincidência entre estes dois objetos, ou seja, a tarefa psicológica e o próprio cérebro, quando se trata da mesma pessoa.

Pressupondo que $S 1$ e $S 2$ sejam dois sujeitos internalizados, que passaram a integrar a psique de um indivíduo, pode-se compreender a afirmação de Vigotski de que "a base da operação instrumental é a união de Pedro e Paulo em uma pessoa", referindo-se a um exemplo de Marx, mencionado na nota de Puzirei:

\footnotetext{
Apenas referindo-se ao homem Paulo como semelhante a si, o homem Pedro começa a relacionar-se consigo mesmo, como uma pessoa. Junto com isso, Paulo, como toda a corporalidade, torna-se para ele uma forma da manifestação da espécie "homem".
}

Portanto, através da internalização dos sujeitos das relações sociais e da identificação entre si e os demais sujeitos, o sujeito relaciona-se internamente da forma como aprende em sua sociedade. Assim, Vigotski conclui que "a relação entre o objeto-estímulo [recado a ser memorizado] e o meio-estímulo [dente de lince] é [...] [constituída] naturalmente do psicológico e do artificial" (ibidem, p.30). 
Vigotski também pondera que "se o objeto é cérebro do outro, então tudo é fácil. Difícil, é quando o objeto é o próprio cérebro" (ibidem, p.30). Quando a operação cognitiva ocorre no próprio cérebro, implica que ela foi internalizada a partir de uma experiência social externa. Assim, trata-se de um processo posterior em relação ao inicial, que seria a relação com outro sujeito, mediada por instrumentos sociais. Esta relação inicial, do sujeito com outro sujeito, é representada na primeira parte do esquema - Instrumento, onde Vigotski conclui que "uma operação instrumental sempre é influência social sobre si, com ajuda dos meios de ligação social e desenvolve-se na forma plena da relação social de duas pessoas" (ibidem, p.30).

Vigotski define a operação instrumental, que aparece na primeira parte do esquema - Instrumento, como sendo "a influência social sobre si, com ajuda dos meios de ligação social e desenvolve-se na forma plena da relação social de duas pessoas" (ibidem, p.30). Esta relação é sempre mediada por instrumentos sociais. No esquema, isso é representado pelo Estímulo (S) e Objeto $(\mathrm{O})$ sendo mediados pelo Instrumento (I). Vigotski explica que, inicialmente, considerava que o Instrumento (I) era o próprio Objeto (O) da operação, mas depois refere que o Objeto (O) da operação também é influenciado pelo Estímulo (S), mas não de forma direta sobre o Objeto $(\mathrm{O})$, pois entre Estímulo (S) e Objeto (O) coloca-se o sinal, aqui representado pelo Instrumento (I). O sinal atua entre "a pessoa e seu cérebro", mas a operação está direcionada para o Objeto $(\mathrm{O})$. Mas o Objeto $(\mathrm{O})$ do cérebro é o processo nervoso, ou seja, a própria operação. Com isso, Vigotski conclui que "a base da operação instrumental é a união de Pedro e Paulo em uma pessoa. A relação entre o objeto-estímulo e o meio-estímulo é [esta relação:] construído naturalmente do psicológico e do artificial"' (p.30). Nas palavras do autor:

\footnotetext{
Dessa forma, uma operação instrumental sempre é influência social sobre si, com ajuda dos meios de ligação social e desenvolve-se na forma plena da relação social de duas pessoas. Antes nós considerávamos: objeto da operação, instrumento. Mas agora - também o objeto da influência do estímulo. O estímulo não atua no objeto da operação. O mecanismo executivo e que fecha - vontade - é resultado das relações sociais: ordem, condição ("um grita, outro combate" - Janet). Entre o que e o que entra o sinal: entre a pessoa e seu cérebro. Ele sustenta a operação, que está direcionada para o objeto. Mas seu objeto é a própria operação, o processo nervoso. Então, a base da operação instrumental é a união de Pedro e Paulo em uma pessoa. A relação entre o objeto-estímulo e o meio-estímulo é [esta relação:] construído naturalmente do psicológico e do artificial (ibidem, p.30, grifos do autor).
}

As ligações que controlam o cérebro são construídas a partir de fora, portanto, o princípio que regula a atividade nervosa interna é resultado da socialização, sendo 
artificialmente produzido. Os mecanismos que possibilitam essa constituição são o condicionamento operante, ou condicionamento dos reflexos inatos (que Ukhtomski conceituava como um órgão funcional), a partir das mudanças experimentadas como resultado dos estímulos recebidos do meio e das interações sociais vividas. Vigotski propõe o conceito de Homo duplex, segundo o qual "por trás de todas as funções superiores e suas relações estão relações geneticamente sociais, relações reais das pessoas.” (ibidem, p.26). A afirmação de que as relações sociais definem a natureza humana do homem constitui, no entender de Sirgado (2000, p.61), uma subversão em relação ao pensamento psicológico tradicional, pois "Vigotski desloca definitivamente o foco da análise psicológica do campo biológico para o campo da cultura, ao mesmo tempo que abre o caminho para uma discussão do que constitui a essência do social enquanto produção humana".

Vigotski também critica no Manuscrito a analogia feita por Pavlov entre o sistema nervoso e uma central telefônica, argumentando que o telefone e a telefonista, ou seja, o aparelho e seu manejo, estão unidos em um único ser. O meio natural interfere e controla o indivíduo através dos reflexos condicionados, que por sua vez não controlam o meio. $\mathrm{O}$ controle do meio é exercido pelo indivíduo através da atividade do trabalho. Para Vigotski, a telefonista não é "a alma", e nem o cérebro, segundo afirmava Pavlov. A telefonista é a "personalidade social da pessoa", a pessoa como unidade social definida, ou seja, "um indivíduo social, real e concreto, cuja singularidade se constitui enquanto membro de um grupo social-cultural específico [...] um ser em si, uma natureza biológica portanto, que tem significação para os outros, e que, através deles, adquire significação para si mesmo" (SIRGADO, 2000, p.74).

Não se trata, portanto, de uma relação entre determinados centros corticais, mas de uma estrutura de personalidade formada a partir de uma origem social que controla os diversos centros corticais envolvidos nos processos psicológicos superiores. Sirgado (2000, p.73-74) assinala que, na compreensão de Vigotski, o signo provoca o deslocamento do mecanismo regulador das funções nervosas, passando das relações internas cerebrais para as relações sociais. Vigotski (ibidem, p.33) resume esta ideia na frase

O que é o homem? Para Hegel é o sujeito lógico. Para Pavlov é o soma, organismo. Para nós é a personalidade social, [ou seja], o conjunto de relações sociais encarnado no indivíduo (funções psicológicas, construídas pela estrutura social).

No entanto, Sirgado (2000, p.57) aponta que o modelo da dupla sinalização proposto por Pavlov, ainda que posteriormente descartado por Vigotski, contribuiu de alguma 
forma para seus primeiros estudos sobre o signo, em que é postulado inicialmente como estímulo externo de uma operação interna.

É interessante notar que durante o texto Vigotski refere-se distintamente ao "cérebro" e à "pessoa", como se se tratasse de dois elementos diferenciados (em trechos como: "entre eu e minha memória", "Se S1 e S2 estão em uma pessoa, então na operação sempre há dois objetos: cérebro e objeto da tarefa psicológica", "Difícil, é quando o objeto é o próprio cérebro"). Isso poderia ser interpretado como uma colocação dualista e idealista, baseando-se na existência de algo supra-cerebral, ou extra-cerebral, mas o conteúdo do texto e o rigor metodológico do autor não alimenta tal hipótese. O trecho acima discutido, no qual o autor conclui a questão, não se resume à relação entre áreas cerebrais e sim no controle destas por uma personalidade de origem social encarnada no indivíduo, o que deixa clara sua concepção monista, não admitindo portanto uma separação entre mente e cérebro.

As funções psicológicas elementares, a base biológica e filogenética, é em grande parte comum entre os indivíduos humanos, mas as funções psicológicas superiores são diferenciadas de acordo com as experiências sociais e de transformação do meio externo ou trabalho. A telefonista, portanto, seria um tipo especial de organização psíquica, que não se assemelha em nada ao conceito idealista de alma, mas ao processo dialético entre telefonista e telefone, mente e cérebro. Sirgado (2000, p.51) reitera esta ideia, ao afirmar que

\begin{abstract}
ao colocar a questão da relação entre funções elementares ou biológicas e funções superiores ou culturais, Vigotski não está seguindo, como o fazem outros autores, a via do dualismo. Muito pelo contrário, ele está propondo a via da sua superação. As funções biológicas não desaparecem com a emergência das culturais mas adquirem uma nova forma de existência: elas são incorporadas na história humana.
\end{abstract}

Fundamentalmente, Vigotski está falando de um processo neurofisiológico, de um controle do cérebro sobre o corpo. O controle do cérebro ou do sistema nervoso sobre o corpo se dá entre duas estruturas fisicamente separadas, ou seja, o regulador A e o que sofre a regulação B estão separados (posteriormente, na definição de sistema funcional como base do funcionamento cerebral, Vigotski e Luria explicitam que não é necessária uma relação de proximidade entre os elementos de um sistema funcional). No caso do ser humano, o indivíduo social A regula a própria atividade cerebral B, e indivíduo social e cérebro (A e B) não podem ser entendidos de forma separada. Assim, não é possível entender o comportamento de forma isolada da pessoa que se comporta, ou o telefone sem a telefonista, com o que Vigotski conclui que "a psicologia não pode apresentar-se nos conceitos dos 
processos, mas do drama" (ibidem, p.26). Holland e Lachicotte Junior (2007, p.110) comentam que a associação literal feita por Vigotski entre este processo e o drama reforçam seu entendimento de que o mesmo só pode ser adequadamente apreendido pelo processo de personificação.

Sendo social a origem das funções psicológicas, Vigotski observa que é "ridículo" procurar sua origem em centros determinados do córtex cerebral, e que devem ser explicadas não por suas ligações internas mas externas, para os estímulos aos quais a pessoa dirige a atividade cerebral. As funções psicológicas superiores não são naturais, mas construções, que operam a partir da interação entre funções, que originalmente era a interação entre pessoas. $\mathrm{O}$ desenvolvimento, portanto, não segue o processo de socialização (de dentro para fora), e sim de individualização de funções sociais (de fora para dentro), ou a transformação das relações sociais em funções psicológicas superiores. A atuação humana sobre o meio externo não organizado, ou meio social, cria construções orgânicas ou funções do cérebro e desenvolve o que antes era instinto: "o homem com ajuda da atividade instrumental constrói novos órgãos, mas orgânicos" (ibidem, p.24).

Vigotski reflete que a aproximação dos estímulos externos corresponde à aproximação dos processos cerebrais, e a atuação no meio resulta no domínio dos processos internos e cerebrais. Ressalta que a ênfase nos processos neurológicos deve ser dada à localização das funções cerebrais, e não dos centros nervosos isolados, o que levou ao conceito de sistemas funcionais, que será abordado mais adiante.

Pode-se notar, a partir dessa breve apresentação, a complexidade dos conceitos aqui colocados por Vigotski. O Manuscrito de 1929 deixa muito claro, no entanto, que a temática cérebro/base material da consciência era central nas reflexões do autor, e sua conceituação está articulada a definições fundamentais da psicologia histórico-cultural. 


\subsubsection{O problema do desenvolvimento cultural da criança (1929)}

As ideias desenvolvidas por Vigotski no Manuscrito de 1929 são apresentadas também em outro texto do mesmo ano, O problema do desenvolvimento cultural da criança (1929), com ênfase no conceito de estado primitivo do desenvolvimento infantil. Utilizou-se nesta análise duas versões do mesmo texto, que foram cotejadas. Uma delas é a versão em inglês, The Problem of the Cultural Development of the Child, (VYGOTSKY, 1929/2010). A outra é El problema del desarrollo cultural del niño, tradução em espanhol feita por Efraín Aguilar a partir de versão em italiano de Luciano Mecacci (VYGOTSKI, 1929/2008). Neste texto, Vigotski refere que no processo de desenvolvimento a criança não se apropria apenas de elementos da experiência cultural, mas de formas de comportamento e pensamento ${ }^{36}$ culturais.

Vigotski distingue duas linhas principais de desenvolvimento da criança: uma linha de desenvolvimento natural do comportamento, relacionada ao desenvolvimento orgânico e maturação, e uma linha de aperfeiçoamento cultural das funções psicológicas, através da apropriação de comportamentos e do desenvolvimento de formas de pensamento culturais, que acontece através da utilização de sinais como forma de realizar atividades psicológicas. Vigotski classifica como estado primitivo infantil aquele que caracteriza a criança que não experimentou um desenvolvimento cultural, ou o fez de forma incipiente, quer por causas internas ou externas, principalmente no que se refere à apropriação da linguagem, o principal sistema de sinais utilizado pela humanidade, segundo o autor. A criança "primitiva" (terminologia utilizada pelo autor) não sofreria de comprometimento orgânico, e caso tenha acesso às condições para apropriar-se da cultura pode alcançar o nível esperado de desenvolvimento em sua sociedade, o que diferencia o estado primitivo da "debilidade mental", ou seja, um comprometimento orgânico que resulte em deficiência intelectual ou nos transtornos globais do desenvolvimento, ou transtornos do espectro autista. A "debilidade mental" e o "estado primitivo" são, portanto, dois fenômenos de natureza e origem diferente. É essencial destacar que Vigotski não concebia as duas linhas de desenvolvimento biológico e cognitivo de maneira estanque - ao contrário, afirmava que

\footnotetext{
${ }^{36}$ No original em espanhol, "razonamiento"; em inglês, "reasoning".
} 
ambas estão imbricadas de tal forma que é praticamente impossível distingui-las e estudá-las separadamente. Ao discutir esse pressuposto de Vigotski, Pino (2002) argumenta que a ideia de que haja no início do processo de desenvolvimento cultural da criança um "momento zero cultural" pauta-se na premissa de um momento mais lógico do que físico, uma vez que seria extremamente difícil localizá-lo empiricamente.

Para Vigotski, a cultura não produz o novo em relação ao biológico, mas o transforma de acordo com as necessidades humanas. Assim, defende que mesmo as formas de comportamento mais sofisticadas podem ser descritas em termos dos processos nervosos e psicológicos envolvidos, sendo que a principal tarefa da pesquisa científica é "analisar as formas [...] culturais de comportamento, decompondo-as em suas partes componentes, os processos psicológicos naturais, ou elementares ou primários”. (s/p). Pino (2002, p.118) assinala que, para Vigotski, deve ser destacada a existência simultânea de continuidade e ruptura entre natureza/funções elementares e cultura/funções superiores, em que a

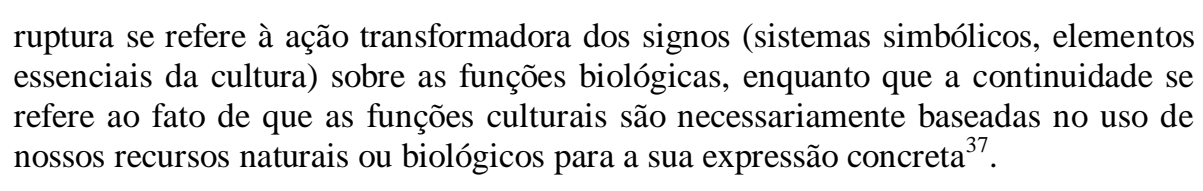

ruptura se refere à ação transformadora dos signos (sistemas simbólicos, elementos refere ao fato de que as funções culturais são necessariamente baseadas no uso de nossos recursos naturais ou biológicos para a sua expressão concreta ${ }^{37}$.

A criança domina uma tarefa que não esteja num grau de dificuldade muito superior pelo uso de suas capacidades naturais, ou seja, conexões associativas ou reflexos condicionados entre estímulos e reações, semelhantes às obtidas por Kohler com os macacos em seus experimentos. Em contraste, há o tipo de memorização cultural, que é aquele que se apóia em uma mediação. Vigotski apresenta o exemplo da mnemotécnica, ao qual recorrerá algumas vezes em seus textos para exemplificar as formas culturais de comportamento. Pela mnemotécnica, ou memorização baseada em sinais, um objeto anteriormente neutro passa a ter a função de signo, na medida em que sinaliza algo não relacionado objetivamente com seu significado, mas através de uma representação. Assim, na memorização natural, uma conexão do tipo reflexa e condicionada se estabelece entre os pontos A e B. Na memorização cultural ou mnemotécnica, a conexão se dá através de um sinal qualquer como mediação, portanto,

\footnotetext{
${ }^{37}$ No original: "Rupture refers to the transforming action of signs (symbolic systems, essential elements of culture) on the biological functions, whereas continuity refers to the fact that cultural functions are necessarily based on the use of our natural or biological resources for their concrete expression." (PINO, 2002, p.118).
} 
AX e BX, atingindo os mesmos resultados, mas de forma indireta. As conexões AX e BX são culturais e do mesmo tipo que as conexões reflexas condicionadas AB.

A estrutura muda, não é criada de fora e incorporada pronta, se origina de acordo com as leis do desenvolvimento e é modelada de maneira decisiva pelo tipo de problema com que a criança se defronta e com os sinais externos que opera. Mesmo depois de formada, a estrutura não fica estática, muda manifestando os sinais do desenvolvimento. $\mathrm{O}$ comportamento novo tem uma história interna e está incluído no processo de desenvolvimento do comportamento da criança, motivo pelo qual Vigotski afirma existir uma relação genética entre determinadas estruturas de pensamento e comportamento cultural e o desenvolvimento do comportamento, que é diferente do desenvolvimento orgânico e obedece a leis definidas. Como reforça Silvonen (2005, p.9), o sinal, ao ser introduzido, atua como uma ferramenta na reorganização da estrutura das funções psicológicas. Assim, a mediação é entendida como promotora do ser atuante no mundo, e não como uma separação: a "atividade de mediação é um processo pelo qual um indivíduo se adapta à essência humana e, portanto, torna-se socializado ${ }^{38}$.

O desenvolvimento do comportamento e do pensamento da criança está sempre sujeito aos mesmos dois fatores que influenciam o desenvolvimento orgânico, ou seja, os biológicos e os sociais. A partir de certos níveis do desenvolvimento e da influência determinante do ambiente, o organismo pode se apropriar dos métodos culturais.

Vigotski (VYGOTSKI, 1929/2008; VYGOTSKY, 1929/2010, s/p). denomina de método instrumental o método através do qual se analisa o comportamento cultural da criança, pois se baseia na descoberta da função instrumental dos signos culturais no seu comportamento e desenvolvimento. A premissa principal do método instrumental é:

a criança, no processo de apropriação de si mesma, ou seja, de seu comportamento, atua da mesma forma como faz ao se apropriar da natureza externa, ou seja, utilizando meios técnicos. O homem se apropria de si mesmo externamente, como se fosse uma das forças da natureza, através da especial e cultural "técnica de signos".

Cabe aqui destacar, de acordo com os objetivos da tese, o papel do organismo como uma condição para o desenvolvimento de determinadas habilidades, e para o qual a

\footnotetext{
${ }^{38}$ No original: "Mediational activity is a process by which an individual adapts the human essence and thus becomes
} 
deficiência proporcionaria uma mudança de direção. Assim, mediante o desenvolvimento orgânico - neurológico, no caso - a criança tem condições de se apropriar do que está culturalmente organizado, condição que é modulada na presença de uma deficiência que tipifique este desenvolvimento.

É importante destacar também a imbricação de aspectos biológicos e psicológicos no desenvolvimento, o que é constantemente enfatizado por Vigotski e atesta o caráter monista da psicologia histórico-cultural.

Outro aspecto a ser reforçado no mesmo sentido é a equivalência entre os estímulos mediados e imediatos do ponto de vista cerebral. As conexões AX e BX são culturais e do mesmo tipo que as conexões reflexas condicionadas $\mathrm{AB}$. Ou seja, o desenvolvimento cultural não cria outro tipo de conexão neural ou se dá a partir de outro tipo de substância, e sim pela complexificação das conexões básicas existentes, modeladas pela experiência social.

\subsubsection{O método instrumental em psicologia (1930)}

Trata-se de um texto-síntese de algumas ideias fundamentais até então para a psicologia histórico-cultural. O texto apresenta-se na forma de 24 parágrafos numerados, tendo servido de base para uma conferência proferida por Vigotski no mesmo ano de 1930.

O tema principal do texto é o caráter instrumental do comportamento humano, cujo objetivo é dominar os próprios processos psíquicos. Tal modo de funcionamento é artificial, ou seja, cultural (portanto, social e não individual), exemplificado por aquisições como a linguagem, a numeração e as obras de arte. Para o autor, a introdução de um instrumento psicológico no processo de comportamento altera a evolução e a estrutura das funções psíquicas, resultando no comportamento caracteristicamente humano, produto da evolução histórica.

Vigotski (1930c/2004) afirma que os atos artificiais resultantes podem ser decompostos em atos naturais, de cuja combinação resultam. Como exemplo, cita a 
lembrança mnemotécnica (como o nó no lenço), explicando a partir do esquema $\mathrm{A}-\mathrm{X}-\mathrm{B}$, onde $\mathrm{X}$ é o fator mediador que se interpõe entre A e B. As ligações A - X e X - B seriam reflexos condicionados, cuja atuação ocorre de acordo com as propriedades do "tecido cerebral" ${ }^{39}$, da mesma forma que a ligação A - B, que seria um reflexo incondicionado atuando sem a presença do mediador $\mathrm{X}$ : “O novo é a direção artificial que o instrumento imprime ao processo natural de fechamento da conexão condicionada, ou seja, a utilização ativa das propriedades naturais do tecido cerebral" (ibidem, p.95).

Na relação estímulo-resposta, segundo o método instrumental, o estímulo atua de duas formas: como objeto e como meio. Para Vigotski, há sempre um $\mathrm{X}$ ou instrumento psicológico mediando o comportamento humano, o que torna ao mesmo tempo necessário operar funções para manejá-lo, bem como torna desnecessários certos processos naturais, que são substituídos pelo X. O instrumento psicológico "recria e reconstrói por completo toda a estrutura do comportamento, do mesmo modo que o instrumento técnico recria totalmente o sistema de operações de trabalho" (ibidem, p.97).

$\mathrm{O}$ ato instrumental é uma função complexa, e simultaneamente a unidade elementar do comportamento: "no ato instrumental reflete-se a atividade relacionada a nós mesmos, e não ao objeto [...] no ato instrumental o homem domina a si mesmo a partir de fora, através de instrumentos psicológicos" (ibidem, p.97-98). Simultaneamente, o ato instrumental amplia as possibilidades do comportamento, na medida em que "põe ao alcance de todos o resultado do trabalho dos gênios" (ibidem, p.98). Como ressalta Minick (1997, p.120), os sistemas complexos de sinais, como a fala, atuam na forma de mediadores do comportamento, a partir dos quais se delineiam as funções psicológicas superiores. Os sinais representam, assim, uma categoria especial de estímulos que funcionam como ferramentas psicológicas voltadas para o controle do comportamento humano, da mesma forma que as ferramentas controlam a natureza.

Nesse texto, Vigotski ressalta a importância da educação, pois entende que ela "é o domínio artificial dos processos naturais de desenvolvimento. A educação não apenas influi

\footnotetext{
${ }^{39}$ Por "tecido cerebral", Vigotski estava provavelmente se referindo ao córtex cerebral, palavra que significa "casca". O córtex cerebral é uma camada de espessura de cerca de 3 milímetros, variando entre 1,5 a 4,5 milímetros dependendo da região, com superfície de cerca de 2.200 a $2.400 \mathrm{~cm}^{3}$, altamente dobrado para ser contido na caixa craniana, contendo os corpos celulares dos neurônios, seus dendritos e parte dos axônios (processos que se estendem além do corpo celular) (GAZZANIGA; IVRY; MANGUN, 2006, p.88).
} 
em alguns processos de desenvolvimento, mas reestrutura as funções de comportamento em toda sua amplitude" (ibidem, p.99). Para ele, a educação e o processo de desenvolvimento biológico são partes de um único processo, em que se pode observar como se reestruturam as funções biológicas da criança através da educação, e também "como a criança realiza em seu processo educacional o que a humanidade realizou no transcurso da longa história do trabalho (ibidem, p.99). Verenikina (2003) reitera a afirmação do autor de que tudo que é criação de uma cultura é categorizado como artefato, de uma simples caneta ou colher até a ciência ou a arte, e é através destes artefatos que a cultura influencia o desenvolvimento, concluindo que a parte mais importante do desenvolvimento psicológico da criança é a aquisição da cultura à qual pertence.

Vigotski refere-se ao tecido (ou córtex) cerebral como tendo certas propriedades naturais, que seriam modificadas e qualificadas pelo ato instrumental ou instrumento psicológico - ou seja, o X que se interpõe no circuito natural $A-B$, resultando no circuito artificial $\mathrm{A}-\mathrm{X}-\mathrm{B}$, onde $\mathrm{A}-\mathrm{X}$ e $\mathrm{X}-\mathrm{B}$ seriam relações artificialmente produzidas.

Apreende-se aqui que Vigotski sistematiza as ideias básicas do método instrumental (algumas já esboçadas no Manuscrito de 1929), assinalando que o cérebro é passível de modificações a partir da introdução de estímulos instrumentais, o que resulta em circuitos artificiais, mediados desde fora ou a partir de ligações externas.

Assim, o caráter biológico do cérebro humano não é definitivo ou "puro", geneticamente determinado, mas formado a partir da relação com o meio externo.

\subsubsection{A psique, a consciência, o inconsciente (1930)}

Ainda de 1930, o texto A psique, a consciência, o inconsciente é importante para entender a origem da psique a partir do cérebro ou da base biológica segundo Vigotski (1930b/2004).

O autor inicia apontando a importância de definir do ponto de vista metodológico os conceitos de psique, consciência e inconsciente, haja vista sua relação com a própria estrutura da psicologia enquanto ciência. Vigotski analisa de uma forma crítica como as correntes psicológicas mais expressivas em seu tempo (reflexologia, psicologia descritiva e psicanálise) abordam essa conceituação, concluindo que tais correntes formularam o problema 
de forma equivocada, o que o torna insolúvel. Contrapõe a tais visões o enfoque dialético da psicologia, que parte da unidade dos processos psíquicos e fisiológicos, para o qual a psique é "uma parte da própria natureza, ligada diretamente às funções da matéria altamente organizada de nosso cérebro. Assim como o resto da natureza, não foi criada, mas surgiu num processo de desenvolvimento" (ibidem, p.144). É importante destacar, conforme lembra Dellari Júnior (2001, p.29), que Vigotski não nega o conceito de inconsciente, considerando-o ora como uma qualidade diferenciada da consciência, ora como um problema epistemológico que a psicologia deve tratar de uma perspectiva dialética.

É importante ressaltar que o autor utiliza o termo psicológico como sinônimo do termo psicofisiológico, justamente por conta de sua concepção da psique, uma vez que seria redundante destacar o aspecto fisiológico na nomenclatura, já que é um princípio básico da visão histórico-cultural a indissociabilidade dos aspectos psíquicos e fisiológicos da consciência. Desta forma, Vigotski defende que a psique não deve ser entendida de forma isolada dos processos cerebrais, e sim como “expressão subjetiva desses mesmos processos, como uma faceta especial, uma característica qualitativa especial das funções superiores do cérebro" (ibidem, p.144). Vigotski ressalva, no entanto, que considerar os aspectos subjetivos e objetivos em sua totalidade não significa identificá-los, (como o faz a reflexologia), defendendo portanto a unidade e não a identidade entre processo psíquico e processo neurofisiológico. Consequentemente, a psicologia dialética tem como objeto de estudo o processo integral do comportamento, não sendo admissível o estudo de processos psíquicos de forma separada dos processos cerebrais.

$\mathrm{O}$ autor conclui que se coloca uma questão muito complexa, dado o desconhecimento até o momento das "condições em que a consciência começa a acompanhar os processos cerebrais" (ibidem, p.152). Argumenta que a dificuldade do problema está em sua falsa formulação, uma vez que os processos cerebrais não seriam acompanhados da consciência, e sim integrariam com ela um "processo integral mais complexo, do qual também faz parte, de maneira orgânica, o nervoso" (ibidem, p.152). Assim, é falsa a busca dos processos psíquicos derivados dos processos nervosos - o que se deve buscar são “determinadas condições conjuntas no sistema nervoso e no comportamento, onde surgem os processos psicológicos integrais" (ibidem, p.152-153).

Neste texto, portanto, Vigotski explicita seu entendimento do que seriam os processos psicológicos, dos quais os processos neurofisiológicos e psíquicos se dão de forma 
indissociável, de forma coerente com sua visão monista acerca desses processos. Tais ideias são sistematizadas pelo autor no texto analisado a seguir.

\subsubsection{Sobre os sistemas psicológicos (1930)}

Este texto procede de uma transcrição estenográfica feita a partir de uma comunicação do autor na clínica de enfermidades mentais da Universidade de Moscou, e foi publicado pela primeira vez na edição das obras completas em russo. $\mathrm{O}$ autor apresenta o texto como uma análise ainda não concluída a respeito dos aspectos genéticos e patológicos do psiquismo, ou seja, seu desenvolvimento e desintegração.

A partir da apresentação e da reflexão sobre diferentes fatos da organização psicológica, apresentados, segundo o autor, "de baixo para cima", Vigotski (1930a/2004) admite que ainda não há evidências teóricas que articulem tais fatos de forma consistente, o que não o impede de ter uma hipótese sobre o tema. Para ele, as alterações não se dão nas funções em si, mas na forma em que estabelecem conexões, que podem ocorrer de infinitas formas. Com o desenvolvimento, novas formas de conexões aparecem, portanto, o que interessa ao investigador é a finalidade deste sistema de conexões, que Vigotski nomeia como sistema psicológico.

Segundo o conceito de sistema psicológico, durante o processo de desenvolvimento histórico do comportamento humano o que muda não são as funções psicológicas em si, como a memória, a atenção ou a percepção, mas as relações que as mesmas estabelecem entre elas. Um sistema psicológico caracteriza-se pelo aparecimento dessas novas relações entre funções psicológicas. Akhutina (2002, p.114) ressalta que o autor, aqui, desenvolve dois princípios da neuropsicologia, que são a gênese social e a estrutura sistêmica das funções psicológicas superiores. Segundo esta autora, ainda no mesmo artigo Vigotski apresenta indícios do princípio de localização dinâmica destas mesmas funções. Akhutina (2002, p.115) propõe ainda que no conceito de Zona de Desenvolvimento Proximal, que será futuramente desenvolvido por Vigotski, é onde se encontra o princípio da organização e localização dinâmica das funções psicológicas superiores, relacionando-se estreitamente com a compreensão atual destas funções. 
Nesta comunicação, Vigotski discute de diversas formas a noção de sistema psicológico, apresentando vários exemplos. Inicialmente, o autor fala sobre as relações entre processos sensoriais e motores, afirmando que constituem um todo, a unidade sensóriomotora, em animais, crianças pequenas ou adultos em estados afetivos primitivos. Porém, tal unidade não se verifica no adulto, cuja motricidade não se caracteriza mais pela sua constituição inicial, mas pelas novas relações estabelecidas com as demais funções. Processo semelhante ocorreria com a percepção, que no processo de desenvolvimento realiza complexas sínteses com outras funções (como a linguagem), o que acaba tornando impossível isolar sua estrutura básica. Vigotski afirma que a percepção passa a integrar o processo de pensamento, ambos ocorrendo de forma simultânea, sendo isso algo característico do processo de desenvolvimento - ou seja, as complexas relações da percepção com outras funções e sua atuação em conjunto como um sistema novo, "cuja desintegração só pode ser observada na patologia" (ibidem, p.110).

A partir dessa conceituação, Vigotski discute a questão do substrato fisiológico desses sistemas, ou seja, a conexão física no cérebro entre os novos sistemas que se estabelecem. Para o autor, tais conexões iniciais só podem se tornar mais complexas graças ao papel que as relações sociais exercem no desenvolvimento, para as quais a linguagem é o exemplo clássico.

Vigotski reafirma o princípio básico da psicologia histórico-cultural, segundo o qual toda função superior aparece duas vezes no processo de desenvolvimento: a primeira, de forma coletiva ou interpsicológica, e a segunda, de forma individual ou intrapsicológica. Tomando o exemplo da linguagem, reitera que a mesma não se resume a um meio de compreender os demais, mas também de alguém compreender a si mesmo: "um indivíduo ordena e outro cumpre. O indivíduo ordena a si mesmo e ele mesmo cumpre" (ibidem, p.113). Define assim o conceito de signo, que em sua origem era um meio de conexão de funções psíquicas de caráter social, e que, uma vez internalizado, passa a unir as funções em um indivíduo, concluindo que "sem esse signo o cérebro e suas conexões iniciais não poderiam se transformar nas complexas relações, o que ocorre graças à linguagem” (ibidem, p.114), retomando as ideias antes esboçadas no Manuscrito de 1929.

Vigotski deixa claro que não se trata aqui do desenvolvimento biológico do cérebro durante a história da humanidade, afirmando que "a evolução biológica do homem já havia terminado antes que começasse seu desenvolvimento histórico" (ibidem, p.115). O que 
se complexifica, para o autor, é o tipo de conexão cerebral que se estabelece com o desenvolvimento de cada ser humano, sempre em um contexto social e cultural. Não se deve confundir, portanto, evolução biológica e desenvolvimento cultural. Akhutina (2002, p.114) faz uma comparação em termos atuais com o computador: "a evolução dos animais é a mudança no hardware, no portador material dos programas, enquanto que no desenvolvimento do homem é o desenvolvimento no software, no sistema flexível de programas que se modifica facilmente ${ }^{40,}$ (grifado no original).

O autor também rejeita a ideia de que uma função psicológica superior mantenha uma correlação direta com sua estrutura fisiológica ou seus aspectos psicológicos, ainda que os sistemas cerebrais complexos sejam produtos de estruturas cerebrais específicas, recusando portanto a noção de localizacionismo estrito. Seu argumento baseia-se em que a complexa estrutura cerebral oferece inúmeras possibilidades para o surgimento de novos sistemas, e que estes não precisam estar determinados estruturalmente a princípio. Vigotski (ibidem, p.130) considera que as diferentes áreas cerebrais relacionam-se entre si, e os processos psíquicos resultam dessa ação conjunta, ao invés da atividade isolada em localidades específicas do cérebro.

Damo-nos cada vez mais conta da manifesta diversidade e do caráter inconcluso das funções cerebrais. É muito mais correto admitir que o cérebro encerra enormes possibilidades para o aparecimento de novos sistemas. Essa é a principal premissa.

Reiterando a ideia da internalização do que antes era uma relação social entre dois cérebros (expressa no Manuscrito de 1929), o autor argumenta que dois pontos no cérebro não podem se conectar diretamente, e que tal conexão é possibilitada somente a partir de fora, do sistema nervoso periférico, ou seja, da ação de um signo através de um terminal periférico. Vigotski discute que indivíduos com lesões em determinados sistemas cerebrais não conseguem executar uma determinada tarefa sozinhos, mas podem fazê-lo através do auxílio de um signo externo. Como exemplo, cita o caso dos pacientes com Parkinson, cuja dificuldade para iniciar voluntariamente o movimento de andar pode ser superada quando alguém lhe diz para dar um passo, ou coloca uma folha de papel no chão e pede que comece a

\footnotetext{
${ }^{40}$ No original: “[...] la evolución de los animales es el cambio en el hardware, en el portador material de los programas, mientras que el desarrollo del hombre es el desarrollo en el software, el sistema flexible de programas que se modifica
} 
andar dando o primeiro passo sobre ela. $\mathrm{O}$ autor postula que os sistemas cerebrais ou psicológicos percorrem sempre estas três etapas: interpsicológica, extrapsicológica e intrapsicológica. As diferenças encontram-se nas conexões que cada um pode estabelecer entre os diversos pontos, portanto, “o decisivo não é a memória, ou a atenção, mas até que ponto o homem faz uso dessa memória, que papel desempenha” (ibidem, p.133).

Neste texto, fica clara a importância que Vigotski confere aos aspectos qualitativos das conexões cerebrais, e não a modificações estruturais morfológicas do sistema nervoso, atribuindo ao desenvolvimento cultural e histórico a aquisição e ampliação das capacidades cerebrais. Para Akhutina (2002, p.115), Vigotski aqui não só levanta conclusões, mas também estabelece um problema experimental novo, o estudo dos sistemas psicológicos e seus destinos.

\subsubsection{Estudos da história do comportamento: símios, homem primitivo e criança (1930)}

Publicado na forma de livro, trata-se de uma coletânea de três textos, dois de autoria de Vigotski (Comportamento do macaco antropóide e $O$ homem primitivo e seu comportamento, VYGOTSKY; LURIA, 1930/1996) e um de Luria (A criança e seu comportamento, ibidem). Segundo Van der Veer e Valsiner (2001), o livro recebeu muitas críticas à época de sua publicação em 1931, atribuindo possivelmente a isso a exclusão deste texto da edição das obras completas.

O prefácio de Knox (1996) é bastante elucidativo, e contribui para o entendimento das ideias principais. Os autores discutem a questão do desenvolvimento histórico do psiquismo relacionado à teoria darwinista da evolução. Essa abordagem sintetiza três linhas principais do desenvolvimento - evolutiva, histórica e ontogenética - tomadas como três diferentes caminhos constitutivos do comportamento humano. É grande o diálogo com as pesquisas da psicologia estrutural, notadamente as realizadas com macacos antropóides. Para Van der Veer e Valsiner (2001), ainda que tais temas fossem básicos para a pesquisa psicológica da época, a junção de temas diversos como os experimentos com chipanzés e as 
pesquisas etnográficas com os ditos "povos primitivos" é provavelmente a origem das críticas dos pesquisadores à obra. Como aponta Rego (1996), ainda que Vigotski tenha procurado enfatizar que a relação entre "homem cultural" e "homem primitivo" não se dava no sentido da superioridade e sim da diferença, algumas afirmações feitas por ele não são claras a esse respeito, assumindo ares de uma abordagem evolucionista.

No primeiro texto - Comportamento do macaco antropóide - Vigotski parte das pesquisas de Khöler com macacos e das teorias estruturalistas, apontando que o indicativo da inteligência no macaco é sua capacidade de usar um elemento de uma estrutura e colocá-lo em outra para superar um desafio (por exemplo, usar uma vara para alcançar uma fruta), o que caracterizaria o primeiro passo na evolução dos processos mentais superiores. Para Vigotski, o traço fundamental da ontogênese é a aquisição de habilidades e modos de pensamento culturais de forma articulada com o desenvolvimento biológico.

Destaque merece ser dado à descrição hipotética feita por Vigotski do tipo de atividade que ocorreria no cérebro do macaco ao executar esta ação. Para ele, a vara e a fruta atuam de forma simultânea como dois estímulos sobre o macaco. Não se tratam de estímulos novos para o macaco, uma vez que ele já os havia experimentado na natureza na forma de estímulos interligados (KNOX, 1996). Portanto, a capacidade de usar a vara não é uma aquisição repentina do macaco, e resulta de sua experiência prévia na natureza, o que cria uma estrutura que é transferida para a nova situação, onde estímulos semelhantes se encontram presentes. Novamente associados, estes estímulos reativam centros do sistema nervoso que já atuavam conjuntamente. Assim, Vigotski afirma que o "efeito desse fenômeno é provavelmente algo como um curto-circuito da corrente nervosa, ou seja, uma ligação entre dois centros muito fortemente excitados" (ibidem, p.77). Tal reação do macaco surge em decorrência de uma situação em que suas ações instintivas não são suficientes para solucionála, obrigando-o a buscar uma resposta diferente, que caracteriza a reação intelectual. Este obstáculo seria responsável pelo aumento da excitação nervosa e consequente aumento da atividade nervosa. Tal hipótese explicaria o surgimento rudimentar do intelecto. Segundo Knox (1996), a repetição habitual é interrompida, e a consciência entra em cena para retomar o controle do que estava relegado ao processamento inconsciente do sistema nervoso. Contudo, o macaco tem uma capacidade limitada de uso do instrumento, e não introduz a esfera da comunicação, devido à sua limitação para produzir um sistema de símbolos. Tais 
aquisições, portanto, não podem ser transmitidas culturalmente, e devem ser reaprendidas pela observação, tentativa e erro a cada nova geração de macacos.

Para Vigotski, o comportamento humano desenvolve-se em três estágios. Inicialmente, das reações hereditárias e instintos, o não aprendido, estruturas inerentes ao organismo. Em seguida, o treinamento ou reflexos condicionados; vêm da experiência, ou seja, o treinamento não cria, mas associa reações inatas. Finalmente, segue-se o comportamento racional. Do ponto de vista estrutural do cérebro humano, Vigotski compartilha da ideia de que novas estruturas erguem-se a partir de estruturas antigas. Vigotski cita a proposição de Pavlov de que o córtex é o órgão por onde circulam os reflexos condicionados, sendo portanto a base orgânica da segunda etapa do desenvolvimento comportamental: "exatamente como o novo cérebro se sobrepõe ao antigo, assim também cada novo passo do desenvolvimento comportamental associado à formação do novo cérebro aparece sobre o estágio anterior" (ibidem, p.84). A visão desse processo por Vigotski é evolutiva, considerando portanto o comportamento cultural como produto da evolução. Segundo ele, o intelecto que começa a surgir na atividade do macaco será base para o desenvolvimento da atividade laboral, vínculo entre comportamento do homem e macacos. Vigotski discorre sobre a relação entre esta evolução e o trabalho, e cita Engels ao afirmar que mão e cérebro jamais se desenvolveram tão rápido quanto no período do desenvolvimento histórico da humanidade. Conclui que o desenvolvimento do comportamento humano é condicionado primordialmente não pelas leis da evolução biológica, mas pelas leis do desenvolvimento histórico da sociedade (ibidem, p.91).

Knox (1996) refere que, neste texto, Vigotski aborda a relação entre a aprendizagem e as mudanças nas estruturas cerebrais, sendo uma espécie de precursor do “neurodarwinismo contemporâneo", segundo o qual ocorre uma seleção ou supressão de neurônios com base na experiência - partindo-se de uma alta densidade neuronal no nascimento, com a aprendizagem e o desenvolvimento, determinados neurônios se fortalecem, enquanto outros se atrofiam, relacionando tal fato com o comentário de Vigotski de que não há progressão sem regressão, e para quem também não é a quantidade de neurônios ou o tamanho do cérebro o que mais importa, mas sim o uso seletivo a que o tecido (ou córtex) cerebral é submetido e que impulsiona o desenvolvimento. Knox conclui apontando que Vigotski não refuta a importância dos mecanismos neurofisiológicos de 
estímulo e resposta, mas se detém na questão da atividade semiótica e da construção do significado.

Referindo-se a Luria, Vigotski afirma que a criança ao nascer não é uma folha em branco, mas uma folha coberta de letras que ainda não estão diferenciadas e organizadas como para o adulto: "o traço fisiológico deixado na retina por um objeto percebido ainda tem que ser processado e avaliado de uma perspectiva de experiência prévia" que a criança ainda não tem, mas que irá constituir a partir de suas experiências (ibidem, p.40). Como ser humano, não irá simplesmente adquirir instrumentos prontos e passados de uma geração para outra, mas também criará instrumentos para si própria. Com isso, poderá ser criado um segundo sistema simbólico, ou seja, palavras ou sinais para substituir aqueles suportes ou instrumentos concretos. A criança, inicialmente, usa os sistemas simbólicos para se comunicar com outros e controlá-los, mas depois internaliza este sistema para regular seu próprio comportamento em outras situações, a partir do que afirma que a natureza da aprendizagem não é ritualizada, mecânica ou comportamental, mas gerativa.

Estes aspectos destacados do texto indicam o lugar privilegiado dado por Vigotski aos mecanismos cerebrais que estão por trás dos comportamentos observáveis. Vigotski não poderia ir além de suposições sobre o funcionamento cerebral que desencadeia ações a partir de estímulos externos, dadas as limitações tecnológicas características da sua época. Ainda assim, fez um esforço teórico para compreender como isso ocorreria, de forma articulada e coerente com a concepção teórica da psicologia histórico-cultural. Isso reitera as ideias anteriormente apresentadas aqui de que para Vigotski não se pode tomar de forma isolada os processos psíquicos dos neurofisiológicos.

Com este texto, encerra-se o segundo momento onde o destaque foi dado ao caráter instrumental do desenvolvimento psicológico humano. Na sequência, passa-se a discutir o papel da linguagem nesse desenvolvimento, bastante explorado por Vigotski e por isso utilizado como ideia-síntese do terceiro momento aqui enfocado. 


\subsection{Linguagem}

A vida social cria a necessidade de subordinar a conduta do indivíduo às exigências sociais e forma, ao mesmo tempo, complexos sistemas de sinalização, meios de conexão que orientam e regulam a formação de conexões condicionadas no cérebro de cada indivíduo. A organização da atividade nervosa superior cria a premissa indispensável: a possibilidade de regular a conduta a partir de fora.

$\left(\right.$ Vigotski $\left.^{41}\right)$

\subsubsection{História do desenvolvimento das funções psíquicas superiores (1931)}

O texto em pauta foi escrito por Vigotski (VYGOTSKI, 1931/2000) em 1931, sendo parcialmente publicado em 1960 (os cinco primeiros capítulos) e integralmente em 1995 (incluindo os capítulos seis até quinze), no terceiro volume das obras completas na edição espanhola, ainda sem tradução para o português. $\mathrm{O}$ volume, com cerca de trezentas páginas, é inteiramente dedicado às funções psicológicas superiores. Neste texto, Vigotski elabora com maior detalhamento e consistência as ideias antes esquematizadas no Manuscrito de 1929, já apresentado nesta tese. Van der Veer e Valsiner (2001) referem que a obra traz de forma ampliada e reelaborada as ideias inicialmente apresentadas em outras obras anteriormente lançadas pelo autor. Como aponta Sirgado (2000), este é o mais completo texto de Vigotski sobre a temática do instrumento e símbolo como processos geneticamente relacionados, não podendo mais ser tratados de forma isolada, como habitualmente se fazia na psicologia da época, segundo a crítica do autor.

Vigotski inicia o texto ressaltando o desenvolvimento cultural da criança como uma categoria de análise fundamental, indicando que tal aspecto não havia ainda recebido atenção da pesquisa psicológica. A tarefa que empreende no texto é uma tentativa de preencher esta lacuna.

\footnotetext{
${ }^{41}$ No original: "La vida social crea la necesidad de subordinar la conducta del individuo a las exigencias sociales y forma, al mismo tiempo, complejos sistemas de señalización, medios de conexión que orientan y regulan la formación de conexiones condicionadas en el cerebro de cada individuo. La organización de la atividad nerviosa superior crea la premisa indispensable, crea la posibilidad de regular la conducta desde fuera". In: Historia del desarrollo de las funciones psíquicas superiores (VYGOTSKI, 1931-2000, p.86)
} 
Novamente aparece aqui sua crítica ao enfoque filogenético aplicado ao desenvolvimento infantil, defendendo que o desenvolvimento psicológico da criança não deve ser comparado com o embriológico. Tais comparações decorrem do fato do cérebro desenvolver-se intensamente nos três primeiros anos de vida e isto coincidir com o desenvolvimento das funções psicológicas superiores principais. Vigotski argumenta que um aspecto não pode ficar limitado pelo outro, uma vez que defende a tese de que o desenvolvimento das funções psicológicas superiores ocorre sem que se modifiquem os aspectos biológicos, portanto, sem que haja um desenvolvimento estrutural do sistema nervoso e do cérebro. Para ele, no caso específico do humano, o desenvolvimento dos órgãos artificiais (como a linguagem e o trabalho) substitui o desenvolvimento dos órgãos naturais, ou seja, do sistema nervoso. Com isso, Vigotski queria dizer que o expressivo desenvolvimento inicial da criança (que pode ser exemplificado pela aquisição da linguagem) não pode ser atribuído ao desenvolvimento estrutural do cérebro, e sim ao desenvolvimento cultural que ocorre nesta fase decisiva do desenvolvimento humano. Ressalta que não há uma diferença biológica entre o "homem primitivo" (entendido aqui como os primeiros hominídeos que adotam a posição ereta e com córtex mais desenvolvido, que seria o órgão responsável pelos reflexos condicionados) e o homem cultural a que se possa atribuir seu desenvolvimento que não seja a experiência histórica adquirida através da cultura. Assim, Vigotski sustenta que não é possível compreender o desenvolvimento das funções psicológicas superiores sem um estudo sociológico do desenvolvimento humano.

A tese fundamental do autor é a de que o desenvolvimento cultural sobrepõe-se ao desenvolvimento orgânico, formando com este um processo complexo e único, cujo entrelaçamento impossibilitaria a identificação do que se pode atribuir a um ou a outro, e que pode ser atingido apenas através de abstrações (ibidem, p.39). O desenvolvimento das funções psicológicas superiores é um processo que faz parte desse processo maior de desenvolvimento.

Assim, no caso do desenvolvimento "anormal" (conforme a terminologia utilizada pelo autor), a adoção de recursos ou vias colaterais de desenvolvimento faz o papel de órgãos artificiais que possibilitam o desenvolvimento histórico-cultural como parte do processo de desenvolvimento psicofisiológico da criança (por exemplo, o uso do braile por uma criança cega no processo de aquisição da escrita). 
No texto, Vigotski dedica uma boa parte à questão metodológica da investigação das funções psicológicas superiores, o que é característico dos seus trabalhos (abordado inicialmente nesta tese no item Uma questão de método: os fundamentos da Psicologia Histórico-Cultural no Materialismo histórico-dialético). O método se baseia na concepção da conduta humana como tendo uma estrutura geológica, ou seja, edificada em sucessivas camadas - o que o autor chama de contexto genético da história da conduta. Tais camadas mais antigas seriam transmitidas com a aprendizagem cultural do ser humano em uma dada sociedade, fazendo parte do processo de formação da conduta.

Esse conceito, bastante inovador, é exemplificado por Vigotski com o comportamento do homem primitivo de recorrer a algum mecanismo divinatório. Vigotski atribui a esta conduta uma forma primitiva de controle do próprio comportamento e do meio cultural, sendo uma demonstração da especificidade típica do processo de desenvolvimento humano. Estaria aí a diferença entre um comportamento superior ou humano de um comportamento básico ou meramente reativo, ou seja, na criação e emprego de estímulos artificiais para o domínio da própria conduta. Vigotski assinala que a existência simultânea de estímulos dados e estímulos criados é um traço distintivo da psique humana. Estes estímulos artificiais introduzidos pelo homem na psique com a função de autoestimulação, visando o autocontrole e o controle da conduta dos demais é o que Vigotski chama de signo.

Vigotski atribui ao cérebro humano, em conjunto com a mão e as ferramentas, a possibilidade do ser humano ampliar seu raio de atividade, o que caracteriza seu desenvolvimento superior em relação aos outros animais. Contudo, o autor enfatiza que a diferença essencial entre a conduta do homem e do animal não está somente na superioridade do cérebro humano, mas no fato de que é o cérebro de um ser social, e que as leis da atividade nervosa superior do homem se manifestam e atuam na personalidade humana. $\mathrm{O}$ homem introduz estímulos artificiais, confere significado a sua conduta e cria, com ajuda de signos, novas conexões no cérebro. Este é o princípio da significação, ou seja, é o homem quem forma, a partir de fora, conexões no cérebro, o dirige e, através dele, governa seu próprio corpo e comportamento.

A vida social, que é característica do humano - uma vez que sua prematuridade ao nascer implica de forma decisiva para sua sobrevivência estar vinculado ao cuidado do outro - cria a necessidade dos indivíduos subordinarem-se às exigências sociais. Isso resulta em complexos sistemas de sinalização, que são meios de conexão que orientam e regulam a 
formação de conexões condicionadas no cérebro de cada indivíduo. A organização da atividade nervosa superior cria a possibilidade e a premissa indispensável de regular a conduta a partir de fora.

Para Vigotski, o condicionamento reflexo não é suficiente para explicar o comportamento humano do ponto de vista psicológico, servindo apenas para esclarecer como as conexões naturais regulam a formação de conexões no cérebro e na conduta. O autor recupera o conceito pavloviano do córtex enquanto um grande quadro de sinais, do qual o homem cria a chave através da linguagem (o grande sistema de sinais), o que não ocorre com os animais, cuja conduta é dominada pelo ambiente. O processo de desenvolvimento humano aperfeiçoa e complexifica ambos, quadro e chave, ou córtex e linguagem.

A atividade de sinalização é análoga ao emprego de ferramentas, sendo ambos os conceitos subordinados ao conceito geral de atividade mediadora. Para Vigotski, o domínio da natureza e domínio da conduta estão reciprocamente relacionados, daí a transformação da natureza pelo homem implicar em sua própria transformação. O uso de meios auxiliares e a passagem para a atividade mediadora reconstrói radicalmente toda operação psíquica, da mesma forma que o uso das ferramentas modifica a atividade natural dos órgãos e amplia infinitamente o sistema de atividade das funções psíquicas.

Assim, Vigotski conclui que o processo de desenvolvimento humano é desenvolvimento cultural, caracterizado por revolução e evolução, bem como colisões das formas culturais de desenvolvimento com as primitivas. É um tipo de desenvolvimento muito diferente do que ocorre com o embrião, que é antes de tudo um desenvolvimento do que era potencial, sendo mais propriamente crescimento e amadurecimento do que desenvolvimento. Diversamente, o desenvolvimento cultural resulta do choque entre organismo e ambiente, produzindo uma adaptação ativa ao meio.

Vigotski aponta que o desenvolvimento cultural do humano ocorre em três etapas. Primeiro, o desenvolvimento inato ou de base hereditária, seguido pelo adestramento, baseado no condicionamento reflexo, até finalmente chegar ao desenvolvimento do intelecto, cuja função é adaptativa e orientada à resolução de tarefas. A terceira etapa é a mais complexa, e paradoxalmente a menos pesquisada.

Segundo Vigotski, o desenvolvimento estratificado da conduta decorre do desenvolvimento cerebral, que ocorre de forma análoga. O desenvolvimento cerebral se dá segundo duas leis, a lei de estratificação e a lei de superestrutura. De acordo com a lei de 
estratificação, os centros superiores e inferiores não se separam no processo de desenvolvimento, mas continuam funcionando em estreita relação, sendo impossível diferenciá-los num sistema nervoso com funcionamento normal. A lei de superestrutura determina que, na passagem de uma função de nível superior, os novos centros se estruturam sobre os centros inferiores, que não desaparecem, mas são superados, no sentido dialético, pelas novas formações. Desta forma, o instinto é superado pelo reflexo condicionado.

No processo de desenvolvimento infantil, a criança começa a aplicar a si mesma as formas de comportamento que os outros aplicavam a ela, ou seja, é feita a assimilação de formas sociais de condutas, que são internalizadas. Assim, o signo, que inicialmente servia como meio de relação social, é incorporado e passa a ser um meio de influência de um indivíduo sobre si mesmo. A base estrutural das formas culturais é a atividade mediadora, ou seja, a utilização de signos externos como meios de desenvolvimento da conduta humana.

Esta é a apresentação sintética das ideias que fundamentam a psicologia históricocultural e que são nesse texto desenvolvidas por Vigotski em profundidade, estando anteriormente esboçadas no Manuscrito de 1929. No que se refere ao cérebro, fica claro o valor dado pelo autor à base orgânica do comportamento, ao mesmo tempo em que Vigotski subordina a importância deste órgão como estrutura isolada a um processo maior de desenvolvimento, caracterizado prioritariamente pelos aspectos históricos e culturais.

\subsubsection{Psicologia educacional [paidologia] do adolescente (1931)}

Neste texto, Vigotski (VYGOTSKI, 1931a/1997) dedica-se a assinalar as importantes diferenças entre o pensamento do adolescente e o da criança, aspecto que até então passara despercebido pela pesquisa de sua época. Contrariando a teoria tradicional em psicologia, Vigotski vê a criança como um ser emocional, e o adolescente como um ser pensante.

É oportuno esclarecer aqui que, embora a noção de diferentes caracterizações do que seja "típico" da infância e da adolescência leve à ideia de periodização do desenvolvimento humano, é importante observar que Vigotski compreendeu essa questão levando em conta o dinamismo do processo de desenvolvimento, enfocando as mudanças 
qualitativas que integram esse processo, que ora se dá de modo estável, ora crítico, como esclarecem Oliveira e Teixeira (2002).

Vigotski critica as teses tradicionais por reduzirem o desenvolvimento do pensamento ao "crescimento ulterior de formas antes existentes" (VYGOTSKI, 1931a/1997, p.49), ou em diferentes conteúdos das formas de pensamento na criança e no adolescente. Em uma frase, "a aparição de novos matizes, uma maior especificação [especialização] e o emprego consciente é o que diferencia o pensamento na idade de transição do pensamento da criança" (ibidem, p.50). Assim, o autor reafirma a importância do desenvolvimento cultural do comportamento, diferenciando-o de forma clara do desenvolvimento no sentido de amadurecimento.

Vigotski estranha o fato de que os mesmos cientistas que negam o surgimento de novas formas de pensamento na adolescência afirmam, contudo, que o pensamento passa por uma verdadeira revolução nesta etapa em termos de seu conteúdo, material com que opera e objetos a que se dirige. Atribui esta contradição ao dualismo da psicologia de sua época, bem como à falta de uma teoria correta sobre a natureza das funções psíquicas superiores como uma formação psíquica qualitativamente nova, e não a mera continuação das funções elementares.

$\mathrm{O}$ autor prossegue discutindo algumas informações sobre o desenvolvimento do cérebro. Critica a visão de K. Buhler e de Edinger de que a formação de novas capacidades cerebrais estaria relacionada com a formação e crescimento de estruturas cerebrais, reiterando que não se pode confundir a filogênese e a ontogênese do cérebro, e que o aspecto fundamental no desenvolvimento histórico da conduta está no surgimento de novas atitudes não relacionadas com a formação de novas partes do cérebro ou com o crescimento das existentes. Segundo Vigotski (ibidem, p.55),

a civilização é uma conquista muito recente da humanidade para que possa ser transmitida por herança. Assim, é difícil esperar que a evolução das funções psíquicas superiores ocorra paralelamente ao desenvolvimento do cérebro, que se realiza fundamentalmente por influências hereditárias.

O autor argumenta ainda que o peso do cérebro pouco se modifica entre os catorze e os vinte anos, o que prova que se deve buscar outro caminho que não o desenvolvimento estrutural do cérebro para explicar o desenvolvimento intelectual que ocorre na adolescência. 
Mais uma vez, Vigotski indica que surge nesta época "uma forma completamente nova de relação entre os momentos abstratos e concretos do pensamento, pela nova forma de sua fusão ou síntese" (ibidem, p.57). O adolescente passa ao pensamento conceitual, assimilando esse processo pela primeira vez, que é bastante complexo e não se trata da mera maturação de funções intelectuais elementares, devendo-se levar em conta que o desenvolvimento humano é um processo dialético, como observado acima. Vigotski diferencia o pensamento infantil, que se dá através de complexos de objetos concretos unidos por uma relação afetiva, do pensamento do adolescente, em conceitos, isto é, através de imagens intricadas do objeto na qual se refletem seus nexos e contatos com a realidade, bem como a essência desse objeto.

Vigotski (ibidem, p.117) faz várias referências ao funcionamento do sistema nervoso. Enuncia a lei básica do desenvolvimento do sistema nervoso e da conduta sobre a transferência de funções entre os centros ${ }^{42}$ inferiores e superiores:

à medida que se desenvolvem os centros ou estruturas superiores, os centros ou estruturas inferiores cedem uma parte essencial de suas antigas funções às formações novas, transpondo-as a estas instâncias superiores, graças ao que as tarefas de adaptação, que nas etapas mais inferiores do desenvolvimento correspondiam aos centros ou funções inferiores, passam a ser desempenhadas, nas etapas superiores, pelas funções superiores.

Por centros inferiores e centros superiores o autor entende as estruturas cerebrais relacionadas com as funções psicológicas inferiores e superiores, respectivamente. Assim, os centros inferiores não são abandonados na medida em que se formam os centros superiores, mas funcionam junto com eles como instâncias subordinadas a estas instâncias superiores (mais recentes na história do desenvolvimento), e que não podem ser estudadas separadamente em um sistema nervoso não danificado. Vigotski conclui postulando três leis fundamentais no desenvolvimento do sistema nervoso: 1) Conservação dos centros inferiores como níveis isolados; 2) Passagem de funções a níveis superiores; 3) Emancipação de centros inferiores em caso de danos ao sistema nervoso.

\footnotetext{
42 Por centro ou estrutura Vigotski entende a formação de novas conexões entre os centros cerebrais responsáveis pelas funções inferiores (biológicas, instintivas ou herdadas), e não o aparecimento de novas estruturas, como já foi esclarecido anteriormente nesta tese.
} 
Sobre o desenvolvimento das funções superiores e sua relação com o sistema nervoso, Vigotski reitera que segue leis distintas das que regem o desenvolvimento das funções inferiores, uma vez que não ocorre simultaneamente ao desenvolvimento do cérebro do ponto de vista estrutural, mas é produzido pelo desenvolvimento histórico do comportamento. As funções psicológicas superiores "surgem e se formam na idade de transição na dependência direta do meio, no processo de desenvolvimento sócio-cultural do adolescente" (ibidem, p.118). Vigotski conclui afirmando que "todas as novas formações psíquicas que se pode detectar no adolescente baseiam-se nesta complexa e ambígua relação entre os processos elementares e superiores" (ibidem, p.118).

$\mathrm{O}$ autor argumenta que esta relação entre os processos elementares e superiores foi estabelecida empiricamente a partir do estudo do sistema nervoso, não trazendo novidades do ponto de vista da lógica dialética. Retoma a definição de Hegel para a palavra "superar", que significa ao mesmo tempo negar e conservar. Tal palavra resume bem o que ocorre no processo de desenvolvimento, “onde cada estágio superior nega o inferior, sem no entanto destruí-lo, e sim o inclui como categoria superada, como momento integrante" (ibidem, p.119)

$\mathrm{Na}$ sequência, Vigotski passa a exemplificar o processo de desenvolvimento psíquico na adolescência a partir das transformações nas funções de percepção, atenção, memória e inteligência prática.

Em relação à percepção, o autor afirma que a nova psicologia contraria a ideia de que a percepção não se desenvolve, e que existiria desde o nascimento. Aponta duas mudanças que ocorrem com a percepção. A primeira é a mudança da síntese primária da percepção, apontando que a constância da percepção está vinculada com a memória, afirmando que "quando olhamos um objeto não o percebemos simplesmente, e sim o recordamos" (ibidem, p.120). Assim, por trás da percepção ocorre um processo complexo de agrupamento de sensações e imagens eidéticas. A segunda mudança é a elaboração secundária ou síntese secundária da percepção, isto é, quando a percepção une-se ao pensamento e à linguagem. Para justificar estas proposições, o autor cita experimentos realizados em seu laboratório com o método de descrição de desenhos.

Vigotski conclui que o desenvolvimento da percepção da criança se dá em quatro etapas: 1) percepção do objeto; 2) percepção da ação; 3) percepção da qualidade e 4) percepção da relação. $\mathrm{O}$ autor questiona as teorias sobre a percepção da psicologia tradicional, 
alegando que a criança desde muito cedo é capaz de estabelecer diversas dependências, nexos e relações (ibidem, p.122). Também afirma, com base em seus experimentos, que a linguagem modifica a percepção (ibidem, p.123).

Graças ao pensamento, os objetos isolados da percepção se relacionam entre si, se regulam, adquirem sentido, passado e futuro. A linguagem, portanto, faz compreender o percebido, permite analisar a realidade e passar da função elementar à superior.

Vigotski subordina, portanto, a ascensão da percepção a uma função psicológica superior pela passagem através do pensamento conceitual, defendendo que "a percepção desenvolvida do adulto recobre a realidade com uma malha de categorias lógicas, reguladoras. Trata-se sempre de uma percepção atribuída de sentido" (ibidem, p.123)

Partindo de seus experimentos com o desenho infantil, assinala que desde cedo a criança não se limita a reproduzir o que vê, e sim o que sabe: "sua memória já deixou de ser um depósito de imagens isoladas para transformar-se em um arquivo de conhecimentos" (ibidem, p.124). O fato novo que ocorre na adolescência é o aparecimento da visão sistemática, regulada e categorial da realidade, ou seja, a passagem do pensamento em complexos para o pensamento em conceitos, onde se sintetizam no ato da percepção o pensamento abstrato e o concreto. $\mathrm{O}$ adolescente passa a regular a realidade percebida por estes conceitos, de forma independente dos complexos anteriormente elaborados. $\mathrm{O}$ autor resume esta transição com a seguinte frase: "a criança, ao perceber, mais propriamente recorda, e o adolescente mais propriamente pensa" (ibidem, p.125).

$\mathrm{O}$ autor conclui reiterando o papel fundamental exercido pela linguagem no processo de pensamento (ibidem, p.126):

O conhecimento no sentido de uma percepção ordenada, categorial, é impossível sem a linguagem. A palavra singulariza o objeto do processo integral de adaptação, de uma situação, o converte em objeto do conhecimento.

Vigotski afirma que processos semelhantes ocorrem com a memória. Argumenta que as bases orgânicas da memória desenvolvem-se antes da adolescência, na qual não ocorre nenhum desenvolvimento expressivo dessas bases, ao contrário da memória superior ou lógica, formada a partir da síntese entre intelecto e memória, e que é, segundo o autor, uma conquista da idade de transição. O desenvolvimento da memória na adolescência ocorre com 
base nas relações da memória com outras funções, o que reestrutura seu lugar nos processos psíquicos.

Segundo Vigotski, a memória realiza três funções distintas em seu estágio primitivo: memorização, imaginação e pensamento, cuja diferenciação é impossível através da observação de crianças em idade escolar, dada sua atuação conjunta. Mais tarde, no entanto, estas funções se desmembram e passam a atuar separadamente: "se na criança o intelecto é uma função da memória, no adolescente a memória é função do intelecto. Assim como o pensamento primitivo da criança se apóia na memória, a memória do adolescente se apóia no pensamento" (ibidem, p.134). Conclui reforçando que o pensamento conceitual começa com o processo de aquisição de linguagem pela criança, o que indica que a memória infantil está mais para um "arquivo de conhecimentos" do que "um depósito de imagens" (ibidem, p.136), portanto, desde cedo a linguagem participa dos processos da memória. O que ocorre na adolescência é uma libertação da memória dessas imagens visuais diretas, e a memória conceitual passa a ser o centro do processo: "a própria memória verbal do adolescente se apóia fundamentalmente na linguagem interna e se converte em uma das funções intelectuais" (ibidem, p.136). Conclui expondo que

\begin{abstract}
surge, portanto, uma relação completamente oposta a que pudemos estabelecer para uma etapa inicial no desenvolvimento da memória e do pensamento. Se naquela etapa a definição do conceito era, de fato, a tradução em palavras de uma imagem concreta ou de uma disposição motora, nesta, ao contrário, a memorização de imagens concretas e disposições motoras são substituídas pela assimilação dos conceitos correspondentes. Se na primeira etapa pensar equivalia a recordar, na segunda, memorizar equivale a pensar. (ibidem, p.136-137)
\end{abstract}

Novamente, o mesmo processo fundamenta o que ocorre com a atenção, ou seja, a transformação das relações entre as funções e a passagem do pensamento conceitual ao primeiro plano. Vigotski argumenta que ocorre um processo de intelectualização da atenção, ou seja, se era característico da idade infantil o pensamento depender da atenção, agora a relação se inverte e predomina a atenção voluntária, que se caracteriza por sua relação com o pensamento.

O autor afirma existir uma estreita vinculação entre o desenvolvimento da atenção na idade de transição e a função dos conceitos. Assevera ser um vínculo duplo, pois a atenção é uma premissa para o desenvolvimento do pensamento, bem como a passagem para o pensamento conceitual mostra que a atenção atingiu um estágio superior, com uma nova, 
superior e complexa forma de atenção voluntária interna. A atenção infantil, apesar de poder ser mais plástica que a adulta, organiza-se de forma esquemática, e estrutura-se em relação com o pensamento egocêntrico da criança. O campo da atenção infantil é mais restrito não porque a criança percebe menos coisas, pois percebe mais e com maior quantidade de detalhes do que um adulto, mas com uma atenção organizada de maneira muito diferente, pois a criança ainda não sabe controlar sua própria atenção. No adolescente, com a passagem para o pensamento conceitual, a atenção passa a ser mediada. Mais uma vez, não se trata de anular a atenção involuntária, mas de sua superação pela atenção mediada, numa formação qualitativamente distinta, resultando em uma síntese complexa.

No que concerne à inteligência prática, Vigotski argumenta que a mesma era entendida como uma mera continuidade do pensamento interno, refletindo seu desenvolvimento. Da mesma forma que o adulto, a criança primeiro pensava para depois agir, e desta forma a velha psicologia justificava o amadurecimento tardio da atividade racional e prática da criança, no início da adolescência. Vigotski é contrário a esta ideia. Argumentando a partir dos experimentos de Köhler com macacos, Vigotski aponta que o intelecto prático é, na verdade, uma forma primitiva do pensamento, contendo formas de atividade mais complexa de forma potencial.

Apoiado em suas próprias pesquisas e nas de diversos cientistas, Vigotski afirma que o pensamento prático depende diretamente dos esquemas sociais a que a criança tem acesso, resultantes de seu processo de adaptação ao seu ambiente. Vigotski aponta novamente a importância da relação entre o intelecto prático e as demais funções do pensamento, o que é um traço distintivo entre a inteligência humana e a do macaco. Mais uma vez, a linguagem exerce aqui um papel crucial na reorganização destas funções. Na atividade infantil, linguagem e ação se aproximam, portanto, a linguagem não é um acessório ou uma função paralela à atividade infantil. A princípio, a linguagem acompanha a ação intelectual da criança, refletindo os resultados da sua ação, e aos poucos passa a ser o centro planejador desta ação, convertendo-se em meio do pensamento, uma vez que reflete a ação intelectual que ocorre objetivamente, e progressivamente a criança se torna consciente desta aproximação sincrética entre pensamento e linguagem, que determina sua conduta antes que ela tenha plena consciência disso. O pensamento se verbaliza ao internalizar a linguagem, ampliando seu escopo de atuação. Diversamente do macaco, a criança, cuja percepção é orientada pela linguagem, conhece o campo de ação, e não apenas o vivencia. O uso da 
linguagem demonstra o papel fundamental que as relações sociais exercem na formação da criança, já que a linguagem é um esquema social universal.

Vigotski aponta que o desenvolvimento da atividade prática relaciona-se com três momentos fundamentais da idade de transição, que são o reequilíbrio entre pensamento e ação, o emprego de ferramentas na formação de processos mediados de conduta, e o início da atividade laboral, que futuramente amadurecerá como trabalho humano.

Analisando a questão específica do cérebro, Vigotski assinala que o pensamento conceitual correlaciona-se com as funções cerebrais, e esta síntese complexa caracteriza-se fundamentalmente por dois momentos. O primeiro é a sua natureza derivada, ou seja, não é o próprio desenvolvimento das funções cerebrais que origina esta síntese, e caso o cérebro permanecesse isolado no processo de desenvolvimento cultural da personalidade, não atingiria tal síntese. Portanto, o cérebro não origina o pensamento lógico por si mesmo, e sim o assimila do processo de desenvolvimento histórico do humano, ou seja, sua estrutura possibilita que estas funções se desenvolvam. O segundo momento refere-se à atuação em conjunto das diversas funções cerebrais na formação dessa síntese, não ocorrendo como resultado da atuação de áreas isoladas.

Vigotski prossegue abordando ainda os casos patológicos da histeria, afasia e esquizofrenia a fim de discutir sua relação com o pensamento conceitual na adolescência. Conclui dizendo que a função de formação de conceitos não apenas modifica o aparato funcional do pensamento e seu conteúdo, mas estrutura a personalidade e a concepção de mundo, que são sínteses superiores que aparecem pela primeira vez nesta fase. Além disso, o pensamento conceitual possibilita a consciência humana. Ao chegar nesse ponto, o adolescente está preparado para dar continuidade à vida do gênero humano.

Van der Veer e Valsiner (2001) assinalam que Vigotski deixou clara a ideia de que o desenvolvimento conceitual na criança, da forma como apresentado e teorizado por ele, é parte de um todo complexo que caracteriza o desenvolvimento do pensamento abstrato, reafirmando que a transição do pensamento em conceitos potenciais para conceitos reais é característica da adolescência, sendo atingida apenas nesta fase.

É notável o esforço realizado por Vigotski para fundamentar sua teoria sobre as funções psicológicas superiores, ao mesmo tempo em que solidifica de forma definitiva as bases da psicologia histórico-cultural, com forte embasamento no funcionamento cerebral como era conhecido até então. 


\subsection{3 $\mathrm{O}$ primeiro ano (1932)}

Vigotski (VYGOTSKI, 1932/1997) examina aqui o desenvolvimento infantil no primeiro ano de vida, buscando aplicar de forma concreta os princípios que havia colocado no estudo da dinâmica do desenvolvimento, com a finalidade de preencher a lacuna que identificava na literatura científica sobre o assunto.

$\mathrm{O}$ autor discute a negação da vida psíquica do recém-nascido pela reflexologia, que o entende como uma espécie de autômato vivo, atuando graças às conexões nervosas. Para isso, a reflexologia baseia-se na imaturidade dos centros nervosos, particularmente do córtex, que está vinculado à atividade consciente. Vigotski rebate este argumento, refletindo que nem toda consciência restringe-se ao córtex, que se relaciona com suas formas superiores. Para o autor, os instintos e afetos mais simples dependem dos centros subcorticais e funcionam em certa medida no recém-nascido. Vigotski defende que o recém-nascido não é um mero ser espino-medular e que o córtex participa de alguma forma em seu comportamento, bem como o fato do seu sistema nervoso ser imaturo não exclui a possibilidade de vida psíquica de forma incipiente. Isso não significa que o bebê ao nascer possua ideias inatas nem percepção real de objetos e processos externos ou ainda aspirações conscientes, mas é possível admitir que haja um estado confuso de consciência, onde se fundem emoções e sensações, segundo a visão de Vigotski.

Neste início, a vida psíquica do recém-nascido caracteriza-se pela predominância de vivências não diferenciadas e uma fusão de afetos e sensações, bem como não há uma separação nítida entre sua existência e a dos objetos sociais e físicos. Suas reações não se focam em elementos isolados, mas em um todo complexo de matriz emocional, com uma percepção de figura e fundo que servirá de ponto de partida para o desenvolvimento posterior da consciência. As primeiras formas de comportamento social aparecerão somente por volta do final do primeiro mês, com a reação ao sorriso e à voz humana, após o que sua vida psíquica de caráter subcortical não desaparece, mas é incorporada nas novas formações nervosas e psicológicas superiores.

Vigotski discorda que o bebê seja um ser associal, defendendo que possui uma sociabilidade totalmente específica, peculiar à sua situação de desenvolvimento única, baseada numa total incapacidade biológica para satisfazer suas necessidades e completa dependência do adulto, resultando em que seus primeiros contatos com a realidade estão 
socialmente mediados, como por exemplo na execução de funções fisiológicas elementares. Mesmo com tal dependência, o bebê carece ainda da linguagem humana, o meio de comunicação social fundamental: "o desenvolvimento do bebê no primeiro ano se baseia na contradição entre sua máxima sociabilidade (devido à situação em que se encontra) e suas mínimas possibilidades de comunicação" (ibidem, p.286). Aos poucos, o bebê vai adquirindo um interesse receptivo pelo ambiente, e por volta dos cinco meses já manifesta atividades além de simples respostas a estímulos e surge a imitação, sendo que o final do primeiro ano caracteriza-se por um interesse ativo.

Sobre o cérebro do recém-nascido, Vigotski aponta que é estruturado em seus aspectos fundamentais (como forma, conexões e posição das partes), e a prova da sua imaturidade é seu crescimento rápido no primeiro ano, o maior proporcionalmente ao que será experimentado durante a vida. Aponta como peculiaridade o predomínio de reações motoras primitivas, que se inibem no adulto e aparecem apenas na patologia. Mais uma vez, Vigotski reafirma o surgimento das funções superiores engendradas nas inferiores, que são a sua base.

Vigotski faz uma série de reflexões sobre o amadurecimento do cérebro no primeiro ano. Assinala que a formação dos centros nervosos ocorre em três etapas. Inicialmente, caracteriza-se pela imaturidade do córtex e corpo estriado e supremacia do pálido, que é o centro superior entre os centros cerebrais independentes, e determina o caráter da motricidade do recém-nascido. Segue-se a esta etapa a maturação do corpo estriado, e formam-se mecanismos que permitem movimentos como sentar-se e ficar de pé. O sistema palidário é um centro reflexo inferior, enquanto o estriado é superior com funções de recepção e coordenação, não estando conectado diretamente com a periferia. Por fim, no terceiro momento, ocorre a maturação do córtex e a participação de suas funções na regulação do comportamento e motricidade, o desenvolvimento da atividade nervosa superior ou sistemas complexos de reflexos condicionados, e a intelectualização e caráter racional, gradualmente adquirido, dos movimentos.

Portanto, as formas primárias de atividade infantil são os instintos e não os reflexos, e o desenvolvimento da motricidade do bebê é caracterizado pela falta de movimentos especializados dos órgãos e a presença de movimentos globais que abarcam todo o corpo.

O processo central que une funções sensório-motoras é o impulso, necessidade ou afeto. A percepção e a ação estão unidas pelo afeto. A consciência do bebê funciona como um 
sistema instintivo que se desenvolve pela influência dos afetos, cuja culminação é a formação da personalidade. Não é por acaso que as funções afetivas estão em relação direta tanto com os centros subcorticais mais antigos, que são os primeiros a se desenvolver e se encontram na base do cérebro, quanto com os lobos frontais, formações cerebrais mais novas e especificamente humanas que são os últimos a se configurar.

É interessante notar que na primeira nota de rodapé da edição russa, na qual este texto foi inicialmente publicado, observa-se que as pesquisas com recém-nascidos realizadas em 1932 confirmaram em parte as deduções de Vigotski no que se refere ao sistema nervoso do bebê e o período de surgimento da vida psíquica individual, bem como a enorme influência do ambiente na maturação dos centros superiores do sistema nervoso.

\subsubsection{Teoria das emoções (1931-1933)}

O texto que recebe o título em espanhol Doctrina de las emociones investigación histórico-psicológica foi escrito por Vigotski entre 1931 e 1933, e teve sua primeira publicação prevista no sexto volume das obras escolhidas em espanhol, o que ainda não ocorreu. Nesta pesquisa, acessou-se o texto a partir de três fontes: 1) o sexto volume da edição estadunidense das obras de Vigotski (VYGOTSKY, 1931-1933/1999); 2) a edição espanhola do texto, Teoría de las emociones, publicada pela editora Akal (VIGOTSKY, 1931-1933/2004); 3) A tradução espanhola realizada por Efraín Aguilar de artigo publicado em Soviet Studies in Philosophy em 1972, com um excerto do capítulo 19 (VYGOTSKI, 1931-1933/2008).

Este texto, que trata de um tema ainda pouco esclarecido pela investigação psicológica e neurocientífica - as emoções -, infelizmente não foi concluído por Vigotski. Trata-se de um texto bastante complexo e com forte marca da metodologia investigativa do autor, sendo inevitável certo desapontamento por não atingir sua conclusão, notadamente ao que se refere à filosofia de Espinosa (ROBINS, 1999, p.ix). 
A teoria sobre as emoções foi selecionada para esta análise por abordar a questão da base biológica das emoções, algo diretamente relacionado à questão da base material da consciência. Vigotski inicia o texto apresentando a teoria James-Lange ${ }^{43}$ sobre a base biológica das emoções, e discutindo a afirmação de James que a mesma se assemelharia à teoria organicista das emoções de Espinosa. No decorrer do texto, Vigotski apresenta uma série de argumentos contrários a esta afirmação de James, como por exemplo a divergência entre a teoria James-Lange e a teoria darwinista. Van der Veer e Valsiner (2001) apontam que o fundamento da crítica de Vigotski estava na abordagem dualista com que a teoria JamesLange enfocava as emoções, ponto de vista comum às teorias da época e para o qual diversos teóricos teceram críticas conhecidas por Vigotski, às quais quis juntar seu parecer sobre o tema, segundo Van der Veer e Valsiner (2001).

Vigotski argumenta que, se o objetivo é estudar a teoria dos afetos de Espinosa no “tecido vivo do conhecimento científico atual” (VIGOTSKY, 1931/2004, p.8), é necessário esclarecer como esta se relaciona com a teoria das emoções de James-Lange. A partir disso, discute de forma minuciosa diversos experimentos realizados com cérebros de animais feitos por variados cientistas, como Sherrington e Cannon, cujos resultados utiliza para apoiar sua argumentação, revelando um conhecimento profundo não apenas da pesquisa da área mas do funcionamento do sistema nervoso. Após este exame minucioso da teoria James-Lange, conclui que a mesma não está relacionada com a teoria de Espinosa, e sim com as ideias de Descartes e Malebranche, apontando a relação feita por James como equivocada. Ressalte-se que, como apontam Van der Veer e Valsiner (2001), ainda que tenha utilizado a teoria da Cannon para refutar a teoria James-Lange, tampouco o autor concorda com ela, argumentando que também era dualista, na medida em que se assentava sobre um conflito entre "corpo" (contribuição periférica do tálamo) e "mente" (contribuição cortical-talâmica) (ibidem, p.379).

Vigotski coloca a possibilidade de que tal erro advenha de um erro ainda maior, que é o de supor uma semelhança entre a teoria de Descartes e a de Espinosa, confusão que se dedica a esclarecer, afirmando que a teoria de Espinosa é a antítese do paralelismo e

\footnotetext{
${ }^{43}$ William James publicou em 1884 um artigo onde argumentou que a experiência emocional é em grande parte devida à percepção de mudanças corporais. Em 1885, Carl Lange propôs uma teoria semelhante, embora os dois não tivessem tido nenhum contato prévio. Suas contribuições ficaram conhecidas como a teoria James-Lange.
} 
dualismo cartesiano, pois a teoria de Espinosa é materialista e monista. No entanto, se a teoria de Descartes afina-se com a psicologia naturalista e explicativa, a de Espinosa estaria mais próxima da psicologia antinaturalista e descritiva - Vigotski irá problematizar estas conclusões como não sendo absolutas.

Vigotski critica o fato da teoria James-Lange atribuir aos órgãos periféricos e não ao cérebro a origem das emoções, o que não significa que o conjunto do organismo não participe deste processo. O cérebro, para Vigotski, é o substrato material da consciência, e o desenvolvimento histórico da consciência está unido fundamentalmente ao desenvolvimento do córtex encefálico. Tal órgão é a base material do desenvolvimento histórico da consciência, e por isso "se distingue de todas as demais partes do organismo e está unido de maneira imediata e direta ao desenvolvimento psíquico do homem" (ibidem, p.136). Encontra-se aqui uma definição vigotskiana do cérebro humano.

Para Vigotski, não existe emoção que por natureza seja inferior ou superior, portanto não há razão para dividir o campo extenso da emoção em duas partes. A única diferença está na complexidade que toda emoção pode adquirir em função do desenvolvimento histórico e social da psique.

Vigotski passa a discutir criticamente como dois ramos da psicologia atuantes em sua época, a psicologia descritiva e a psicologia explicativa, conceituam o psiquismo. Ambos têm entendimentos diversos da vida mental, a ponto de poderem ser considerados como duas disciplinas teóricas diferentes. Para a psicologia descritiva é possível entender as conexões da vida mental, e esta se define como uma totalidade de relações de propósito e significado. Já para a psicologia explicativa, chega-se a uma descrição e explicação dos elementos e efeitos da vida mental, que pode ser definida como a totalidade de conteúdos da consciência a serem explicados.

Vigotski critica ambos os pontos de vista face à psicologia histórica e cultural. Para ele, embora os argumentos apresentados tenham forças e fraquezas, ambos coincidem apesar de sua aparente contradição. Uma acaba gerando a outra: a teoria de James-Langue e sua busca da explicação dos sentimentos superiores acaba gerando a teoria de Sheller e sua recusa em explicar os mesmos sentimentos; no entanto, ambos parecem concordar que a única explicação razoável deverá ser baseada na mecânica neurofisiológica.

Vigotski também critica a tentativa de a psicologia descritiva de Dilthey basear-se em Espinosa, pois para ele a leitura que a psicologia descritiva faz da sua obra não é da parte 
viva dirigida ao futuro, e sim da parte inerte, dirigida ao passado, que se reduz ao uso da nomenclatura. Entende que esta forma de privilegiar explicações teleológicas em detrimento das causais remonta a uma época anterior a Espinosa, que o filósofo justamente tentou combater, buscando uma explicação materialista das paixões humanas. Espinosa lutou com o dualismo cartesiano, que é revivido pela psicologia descritiva, além de seu método ter premissas irreconciliáveis com a psicologia descritiva, segundo Vigotski. Lange incorre no mesmo erro ao citar Espinosa como se aproximando de sua própria teoria fisiológica das emoções, julgando apenas o fato de que o filósofo não considerava o fenômeno corpóreo das emoções como dependente dos movimentos espirituais. Para Vigotski, o fato de tanto Lange quanto Dilthey, com suas teorias aparentemente polarizadas, remeterem-se à teoria espinosana das paixões não pode ser coincidência, e sim consequência de um parentesco metodológico mais profundo, que Vigotski identifica no princípio mecanicista cartesiano que estaria por trás de ambas as teorias.

Por outro lado, seria mais lógico que Espinosa fosse colocado ao lado dos que defendem o estudo científico dos sentimentos em oposição ao estudo metafísico, desviando-se portanto da psicologia descritiva. Contudo, ao reviver os princípios espiritualistas e teleológicos do século 17, a psicologia descritiva dirige-se essencialmente a Descartes e não a Espinosa. Vigotski (ibidem, p.236) aponta, entretanto, que entre a psicologia descritiva e Espinosa há em comum a busca de uma interpretação não mecanicista dos sentimentos. Assim, as linhas do pensamento de Espinosa encontram certa continuidade tanto em Lange como em Dilthey, ou seja, nas psicologias explicativa e descritiva.

\begin{abstract}
Assim, o que constitui o núcleo mais profundo da teoria de Espinosa é justamente aquilo que não existe em nenhuma das duas partes em se dividiu a psicologia contemporânea das emoções: a unidade da explicação causal e do problema do significado vital das paixões humanas, ou seja, a unidade das psicologias descritiva e explicativa do sentimento ${ }^{44}$.
\end{abstract}

Assim, Vigotski critica tanto a teoria das emoções de Descartes quanto as aparentes oposições feita ao seu pensamento, que porém mantém-se atadas ao dualismo

\footnotetext{
${ }^{44}$ No original: "Así, lo que constituye el nucleo mas profundo de la teoria de Spinoza es, precisamente, 10 que no existe en ninguna de las dos partes en las que se ha dividido la psicología de las emociones contemporánea: la unidad de la explicación causal y del problema del significado vital de Ias pasiones humanas, la unidad de las psicologías descriptiva y explicativa del sentimiento".
} 
cartesiano, seja pelo reducionismo ao fisiológico (o caso da teoria James/Lange), seja pela abstração de um psiquismo independente dos processos neurofisiológicos (como Dilthey, por exemplo). Desse modo, Vigotski aponta, ao mesmo tempo, os limites fundamentais da teoria das emoções de Descartes e os de seus “discípulos involuntários” (DELARI JUNIOR, 2009, p.1).

Para Van der Veer e Valsiner (2001), o fundamento monista da teoria espinosana provavelmente explica a grande atração que o autor tinha pela obra do filósofo holandês, uma vez que a psicologia histórico-cultural tem como seu fundamento a crítica à visão dualista da psicologia humana.

Pode-se considerar, a partir desse breve resumo, que ainda há muito a ser explorado neste texto, apesar da sua inconclusão, ou ainda justamente por isso. A Teoria das emoções seria mais bem caracterizada no âmbito desta tese como um texto de transição entre o terceiro e o quarto momento, pois se, dada sua localização cronológica, a mesma é contemporânea aos textos vigotskianos sobre o caráter instrumental da psique, tal aspecto não é destacado nela. Conforme discutem Van der Veer e Valsiner (2001), é provável que Vigotski tenha deixado a questão das emoções para um segundo momento, dedicando-se à conclusão de outros trabalhos considerados mais prementes por ele. Contudo, a Teoria das emoções não trata propriamente de aspectos neurológicos como os textos do quarto momento, podendo ser caracterizada mais como uma crítica fundamentada em uma leitura filosófica das teorias acerca da psicologia das emoções. Fica situada, portanto, na zona fronteiriça entre o terceiro e quarto momento da análise aqui empreendida. 


\subsection{Cérebro}

A ideia da localização das funções psicológicas superiores não pode ser entendida
senão como cronogênica, sendo o resultado do desenvolvimento histórico. As
relações características das regiões do cérebro se formam na evolução, e uma vez
formadas de uma certa forma operam no tempo, o que exclui a possibilidade de
derivar um processo complexo de um único local. (Vigotski $\left.{ }^{45}\right)$

\subsubsection{O problema mente-corpo (1932)}

Este primeiro texto do quarto momento constitui-se de anotações do autor a respeito da relação mente-corpo, que foram desenvolvidas em maior ou menor profundidade nos anos seguintes, como poderá ser visto nos textos produzidos nesta época e que serão analisados neste quarto momento.

Vigotski (VYGOTSKY, 1932/1999) inicia relacionando a crise da psicologia, tema recorrente em sua obra, com a quebra do paralelismo psicofísico. O paralelismo é conceituado por Vigotski como um compromisso entre o pensamento físico e matemático introduzido na psicologia a partir das ciências naturais, por um lado, e o entendimento précientífico religioso, por outro. Relaciona esses pontos de vista conflitantes com a oposição que aponta entre o dualismo cartesiano e o monismo de Espinosa (aspecto discutido em seu texto sobre as emoções, analisado anteriormente). Atribui a quebra da visão do paralelismo ao avanço das concepções científicas, que enfraquecem o compromisso entre o ponto de vista religioso e científico primitivo outrora predominante. A ideia de interação entre mente e corpo é apontada como uma forma de reviver o paralelismo, e portanto é criticada por Vigotski.

Vigotski argumenta que tal questão deve ser encarada sob o prisma de um novo tipo de desenvolvimento, o histórico. Aponta que a neurologia oferece o argumento de um

\footnotetext{
${ }^{45}$ No original: "Pero la idea que la localización de las funciones psíquicas superiores no puede ser entendida sino como cronogénica, siendo el resultado del desarrollo histórico; que las relaciones características de las partes únicas del cerebro se forman en el curso de la evolución y, una vez formadas en cierto modo, operan en el tiempo, y que ello excluye la posibilidad de hacer derivar un proceso complejo de un solo sector". In: El problema de el desarrollo y la desintegración de las funciones psíquicas superiores. (VYGOTSKI, 1934/2008, s/p).
} 
cérebro real contra um cérebro hipotético, e que a psicologia animal e a teoria evolucionista fortalecem o argumento do desenvolvimento contra o da suposta existência prévia da mente, assim como a função biológica da consciência, ao invés de uma suposta existência contígua desta ao corpo.

Vigotski aponta como principal falha das teorias psicológicas como a de Bergson e a Gestalt o fato de não abordarem o desenvolvimento histórico da consciência. Seu ponto de vista é que há uma unidade do processo mente-corpo, com supremacia dos aspectos psicológicos (no sentido em que Vigotski entende a definição de psicológico, ou seja, aspectos psíquicos e físicos unidos indissociavelmente), em cujo estudo se encontra a chave do problema mente-corpo.

Seu principal argumento está na possibilidade criada pela consciência de novos movimentos no processo mente-corpo e assim de novas funções, particularmente do desenvolvimento histórico que caracteriza a mudança nas relações entre as funções, o que não é possível no nível do desenvolvimento orgânico isoladamente. Graças à experiência social, predominam na consciência estruturas construídas pela comunicação - o que é impossível para um é possível para dois (ibidem, p.15). A questão das conexões extracerebrais também é colocada como um argumento nesse sentido.

\subsubsection{Sobre localização (1934)}

Também em forma de esboço do caderno de notas de Vigotski (VYGOTSKY, 1934/1977), este texto sobre a localização cerebral de funções psicológicas data de 1934, sendo portanto uma de suas últimas produções. Seu conteúdo é compatível com trabalhos datados do mesmo ano, O problema do desenvolvimento e da desintegração das funções psicológicas superiores e A psicologia e a teoria da localização das funções psíquicas, que serão analisados na sequência.

Vigotski discute a premissa de que há uma identidade fundamental na localização das funções psicológicas superiores e das funções fisiológicas inferiores. Compara seu ponto de vista com o de Kurt Goldstein (1878-1965), neurologista e psiquiatra alemão cuja obra foi influenciada pela teoria da Gestalt. Goldstein criticou o trabalho de Carl Wernike (18481905), médico e anatomista alemão (nascido na região conhecida como Silésia), que 
pesquisou as regiões cerebrais envolvidas nos distúrbios da linguagem (a região posterior esquerda do giro temporal superior ficou conhecida como área de Wernicke em sua homenagem). Segundo Vigotski, Goldstein entendia que Wernicke estava errado, e defendia que a percepção tinha um caráter estrutural, diferindo apenas em grau entre os homens e os animais. Assim, para Goldstein a localização cerebral da função seria a mesma, quer se tratasse de um reflexo, quer se tratasse do pensamento categorial, ou seja, de processos mentais e não-mentais: a análise de um leva à compreensão do outro. Vigotski defende a especificidade da localização das funções tipicamente humanas no cérebro, sendo portanto contrário à visão de Goldstein. Rebatendo o argumento de Goldstein acerca dos prejuízos das funções na esquizofrenia, Vigotski afirma que as funções não sofrem tais prejuízos igualmente, havendo uma hierarquia de centros, e não um único centro.

\subsubsection{A psicologia e a teoria da localização das funções psíquicas (1934)}

Neste texto, Vigotski (VIGOTSKI, 1934/2004) dedica-se de maneira específica à questão da localização cerebral das funções psicológicas superiores. As ideias esboçadas no rascunho do caderno de notas, vistas no texto anterior, encontram aqui um maior desenvolvimento. Como lembra Moll (2002), a morte precoce de Vigotski o impediu de ler esta comunicação no Primeiro Congresso Ucraniano sobre Psiconeurologia, sendo apresentada na ocasião por um substituto, de acordo com Van der Veer e Valsiner (2001).

Vigotski começa enunciando como cerne do problema a relação entre as unidades estruturais e as funcionais envolvidas na atividade cerebral, considerado à luz do debate entre as visões atomista e integradora do funcionamento cerebral. Novamente, a ideia de funcionamento diferenciado do cérebro, e não do surgimento de novas estruturas, é defendida pelo autor. Vigotski considera que, apesar dos avanços científicos da neurologia, não foi dada ainda uma resposta satisfatória à questão da localização, o que atribui à falta de um sistema de análise psicológica e estrutural eficiente. $\mathrm{O}$ autor aponta as limitações da psicologia estrutural em dar uma resposta para a questão da localização restrita versus o funcionamento do cérebro como um todo, oscilando entre o espiritualismo e o materialismo, e não fazendo mais do que unir mecanicamente as duas posições sem superar o problema. O caso da localização cerebral nos seres humanos é onde essa deficiência pode ser mais sentida. 
Como forma de superação desta dicotomia, Vigotski propõe a hipótese de uma teoria histórica das funções psicológicas superiores, baseado em suas pesquisas e experiência clínica. Esta teoria fundamenta-se na organização e no significado da consciência humana, que se caracteriza pela variabilidade das conexões e das relações interfuncionais, pela formação de sistemas dinâmicos complexos e pela reflexão generalizada da realidade, características expressas segundo a lei dos saltos dialéticos que se dão entre matéria inanimada, sensação e pensamento. Como apontam Van der Veer e Valsiner (2001), esta visão histórica sobre o desenvolvimento das funções cerebrais levará Vigotski a estabelecer diferenças entre lesões cerebrais que ocorrem na infância ou na idade adulta, justamente devido ao período de desenvolvimento em que o indivíduo se encontra.

A partir dessa hipótese de trabalho, Vigotski é conduzido para três conclusões fundamentais. Para Akhutina (2002, p.117), Vigotski enuncia através destas proposições o seu "testamento neuropsicológico". Primeiro, a função de conjunto das partes na atividade cerebral, ou seja, uma função específica, não se resume à atividade de um centro específico, mas resulta de uma atividade integrada entre vários centros diferenciados e relacionados hierarquicamente. Portanto, o cérebro não funciona de forma homogênea, quer seja numa função global (articulando vários centros), quer seja numa função parcial (que implicaria um centro especializado). Tanto em uma quanto na outra ocorrem divisão e unidade, especialização e integração, que não se excluem mas se pressupõem, numa relação dialética entre o conjunto e as partes do cérebro. Ainda no âmbito desta primeira conclusão, e apoiado em suas investigações experimentais sobre lesões cerebrais, Vigotski conclui que a função do conjunto organiza-se como uma atividade integrada a partir de relações dinâmicas e hierarquicamente organizadas entre os centros cerebrais. Tanto a função das partes quanto a do todo são estruturadas como atividades integradas e interrelacionadas. Para ele, as novidades introduzidas na organização do cérebro pelas funções psicológicas superiores não podem ser ignoradas, pois elas produzem uma nova forma de funcionamento da consciência, que vai além da inibição e estimulação dos centros inferiores. Moll (2002) aponta que, para Vigotski, a mudança na relação entre os processos superiores levaria também a mudanças na relação entre sistemas no córtex.

A segunda conclusão de Vigotski refere-se à correlação entre as unidades funcionais e estruturais nos casos de deficiências e lesões. Tal conclusão é resumida na frase: “o desenvolvimento vai de baixo para cima, a decadência de cima para baixo" (ibidem, 
p.198). Ou seja: nos casos de lesões cerebrais, os centros superiores são mais afetados que os inferiores, pois são mais recentes do ponto de vista ontogenético, ainda que ambos dependam funcionalmente entre si. No caso da deficiência ocorre o contrário, isto é, os centros inferiores são mais afetados que os superiores. A explicação para isso é que as relações entre centros superiores e inferiores são produtos do desenvolvimento.

A terceira e última conclusão de Vigotski alude ao caso específico da localização das funções no cérebro humano e do papel fundamental exercido pelas conexões extracerebrais. Por conexões extracerebrais, Vigotski entende as conexões que são estabelecidas inicialmente através da atividade externa e social, e só depois são interiorizadas e transformadas em atividade interna (ou seja, sua teoria sobre a origem social das funções psicológicas superiores). Vigotski conclui que as funções lesadas podem ser compensadas, portanto, com seu deslocamento para fora, transformando em atividade externa o que antes competia a uma função interna. Ao considerar as conexões extra-cerebrais, portanto, como lembra Moll (2002), Vigotski destaca sua construção histórica e cultural a partir de instrumentos auxiliares externos. Portanto, o córtex cerebral é um órgão que cria órgãos, segundo Leontiev (1982, apud MOLL, 2002, p.47).

Assim, Vigotski está aqui apresentando um sistema de análise psicológica para suprir a lacuna por ele identificada. Tal sistema seria baseado em dois aspectos: a análise por unidades e a análise por sistemas. A análise por unidades refere-se à substituição da decomposição de um sistema (ou complexo) psicológico em seus elementos integrantes por uma análise em que se decomponha o conjunto em unidades que conservem em sua forma mais simples as propriedades inerentes ao conjunto. Já a análise por sistemas ou interfuncional é aquela capaz de abarcar a atividade em seu conjunto, das conexões e relações interfuncionais, substituindo a análise estrutural e funcional, que teria uma visão estanque do funcionamento cerebral.

Vigotski conclui defendendo que a questão da localização deve ser considerada de forma diferenciada nos animais e no homem, e que a transposição direta dos dados obtidos pela pesquisa com animais levaria a graves erros, pois o cérebro humano se caracterizaria pela presença de um princípio localizador, devido ao que se tornou o "órgão da consciência humana" (ibidem, p.200). Para Moll (2002, p.47), uma síntese do pensamento do autor neste tópico seria: "as relações sociais e a cultura são as fontes da mente, o cérebro, em seu funcionamento, apenas seu órgão, e a atividade social única de cada sujeito, sua origem”. 


\subsubsection{O problema do desenvolvimento e da desintegração das funções psíquicas superiores (1934)}

Este texto resulta de uma conferência proferida por Vigotski (VYGOTSKI, 1934/2008) no Instituto de Medicina Experimental da União Soviética em 28 de abril de 1934, publicada em russo pela primeira vez em 1960 (e aqui em uma tradução de Efraín Aguilar do livro A psicologia soviética, organizado por Luciano Mecacci e publicado em italiano em 1976). Segundo Akhutina (2002), Vigotski e seu grupo haviam sido convidados por Graschnkov, diretor do instituto, a trabalhar no mesmo, fato impossibilitado por seu falecimento iminente.

Van der Veer e Valsiner (2001) apontam que o autor deu preferência no texto a reiterar a necessidade de uma análise estrutural na forma com que as funções superiores se organizam, ao invés de deter-se na análise da deterioração propriamente dita das mesmas funções.

Vigotski inicia apresentando duas tendências predominantes na psicologia internacional do seu tempo. A primeira delas é a naturalista, segundo o qual a psicologia humana e seus processos psíquicos superiores nada mais são do que os mesmos princípios da psicologia animal, diferindo apenas quantitativamente - esta é a ideia da psicologia estrutural, cujos resultados obtidos são criticados por Vigotski, pois, segundo ele, não passam de transposições de dados da pesquisa animal para a psicologia humana, descaracterizando-a. A segunda tendência é representada pela psicologia descritiva, de caráter idealista, que postula as funções superiores como sendo de natureza espiritual, sem explicações causais relacionadas aos processos cerebrais. A partir disso, Vigotski conclui que, não obstante a grande quantidade de pesquisas, a psicologia humana ainda não se constituíra como ciência.

Em relação ao desenvolvimento e desintegração das funções psicológicas superiores, Vigotski afirma que é necessário compreender sua natureza. As funções psicológicas superiores são formas superiores de atividade diferenciada das funções elementares, de caráter herdado. No desenvolvimento humano, o que se destaca não é o desenvolvimento de cada função psíquica, e sim a modificação das relações entre as funções.

Para Vigotski, a consciência não resulta de uma mera soma de funções simples, ocorrendo justamente o contrário: as funções simples desenvolvem-se de forma dependente da consciência como um todo. O desenvolvimento da consciência é a transformação da 
relação entre as partes isoladas e as formas de atividade, ou seja, a modificação da relação entre o todo e as partes. As funções se desenvolvem de forma interdependente - a memória depende da percepção, por exemplo. Assim, a formação das funções psicológicas superiores baseia-se na formação de sistemas psicológicos.

Durante o processo de desenvolvimento infantil, a relação entre as funções psicológicas elementares muda e elas se integram a partir das experiências vivenciadas, resultando nas funções psicológicas superiores. Todas as funções psicológicas superiores têm uma base psicológica comum, e estão mais relacionadas entre si que as funções psicológicas elementares ou inferiores. Assim, as funções psicológicas superiores não decorrem de um desenvolvimento em continuidade das inferiores, mas formam com elas um todo, onde as funções psicológicas elementares existem como parte desse todo. A linguagem e pensamento verbal têm um papel fundamental na formação das funções psicológicas superiores.

Vigotski também comenta aqui sobre a questão da localização. Refere que a teoria localizacionista não vai além de enunciar dois momentos funcionais na atividade cerebral, alternando-se entre funções específicas e inespecíficas. Para o autor, a teoria da dupla função dos centros cerebrais representa a união de dois velhos pontos de vista que não resolvem o problema. A favor da sua hipótese, Vigotski apresenta resultados de estudos clínicos de crianças e adultos com lesões cerebrais, sublinhando a diferença do quadro em relação à idade em que a lesão ocorre, se na infância ou no cérebro adulto desenvolvido. Apresenta a lei do desenvolvimento segundo a qual uma lesão, quando ocorre em um centro cerebral de um adulto, o centro inferior é mais afetado que o superior, ocorrendo o contrário na criança, ou seja, o centro superior é mais afetado que o inferior. A interdependência dos centros é inversa nos dois casos. Van der Veer e Valsiner resumem este ponto de vista expondo que "danos cerebrais semelhantes (de crianças e de adultos) podem produzir sintomas muito diferentes nas esferas psicológicas, ao passo que quadros sintomáticos podem refletir um dano cerebral fundamental semelhante" (2001, p.196), apresentando tal argumento como uma defesa de uma visão sistêmica do funcionamento cerebral.

Tanto no caso do desenvolvimento quanto na degeneração, pode haver fenômenos inversos da relação entre os centros, como uma consequência remota da lesão oposta. Isso exclui o argumento de que um centro está ligado apenas de forma inespecífica com as outras funções, e que a lesão de um determinado centro não causa um efeito equivalente em seu confronto com outros centros. A lesão tem uma relação específica dependendo do centro em 
que ocorre, e tal relação é estabelecida durante o desenvolvimento - assim, os transtornos que surgem depois da lesão de um determinado centro podem ter características diferentes. Assim, Vigotski conclui que a ideia de que as funções psíquicas superiores sejam localizadas especificamente em cada centro é infundada. Se assim fosse, não haveria uma atividade diferenciada e unificada de um sistema íntegro de centros, e no caso de uma alteração, os demais centros não seriam afetados de modo específico, mas sempre da mesma forma. O que caracteriza fundamentalmente a questão da localização, portanto, é seu desenvolvimento ao longo do tempo.

Vigotski afirma também que o cérebro humano possui princípios de localização novos em relação aos animais. As funções especificamente humanas não podem ser consideradas como uma aparição simples de funções novas ao lado das que já existiam no cérebro pré-humano. Assim, um âmbito de investigação fecunda e original é a complexidade e originalidade das funções psicológicas superiores.

Como nota final, é interessante observar que Vigotski não faz em seus textos sobre a localização uma definição precisa dos termos utilizados, como centros cerebrais superiores e inferiores, ou funções superiores e elementares. Nesse sentido, é interessante destacar uma observação feita por ele durante esta palestra (ibidem, s/p):

Pode-se pensar que, ao examinar o problema de tais funções superiores, deva-se iniciar dando uma definição clara das mesmas e indicar quais critérios permitem distingui-las das funções elementares. Contudo, creio que a definição exata não surge por princípio do conhecimento científico. Assim, penso limitar-me inicialmente a definições empíricas e heurísticas ${ }^{46}$.

A questão das definições de Vigotski sobre alguns termos que utiliza com frequência (como cultura, por exemplo) é discutida por Pino (2005). Algumas razões para esta falta de precisão foram ventiladas, sendo provável que Vigotski não considerasse necessário fazê-lo. Para o pesquisador de sua obra, isso acrescenta mais um obstáculo, para o que é necessário buscar a contextualização dos termos utilizados de forma coerente com sua concepção teórica e com seus pressupostos metodológicos fundados no materialismo

\footnotetext{
${ }^{46}$ No original: "Se podría pensar que, al examinar el problema de tales funciones superiores, se deba comenzar dando una clara definición de ellas e indicar cuáles criterios permiten separarlas de las funciones elementales. Sin embargo, creo que la definición exacta no surge por el principio del conocimiento científico. Pienso limitarme inicialmente a definiciones empíricas y heurísticas."
} 
histórico-dialético (PINO, 2005). Tais aspectos serão aprofundados no próximo capítulo, em que se discutem as ideias aqui compiladas.

\subsubsection{O pensamento na esquizofrenia (1931)}

Vigotski (1931/2008) discute a relação entre o desenvolvimento do pensamento na adolescência, por um lado, e a deterioração do pensamento na esquizofrenia por outro. Tal relação já fora abordada pelo autor no texto Psicologia [paidologia] educacional do adolescente, (previamente discutido aqui). Segundo Van der Veer e Valsiner (2001), o interesse de Vigotski em discutir esta psicopatologia relacionava-se com sua teoria a respeito do desenvolvimento dos processos mentais, com a passagem do pensamento por complexos para o pensamento por conceitos.

A adolescência caracteriza-se, segundo Vigotski, por esta passagem, qual seja, do pensamento por complexos para o pensamento conceitual, o que revoluciona o processo intelectual e determina a estrutura dinâmica da personalidade. Inversamente, a deterioração mais importante do pensamento que ocorre na esquizofrenia é um distúrbio na formação de conceitos. Portanto, a psicologia do adolescente fornece a chave para a compreensão da esquizofrenia, da mesma forma que o pensamento esquizofrênico ajuda a compreender a psicologia da adolescência. Em ambos, o ponto fundamental é a compreensão da função da formação de conceitos.

Vigotski aponta que, em pessoas com esquizofrenia, o pensamento é regressivo, com métodos de associação comuns em crianças antes da adolescência. Assim, o dano na formação do conceito leva de volta ao pensamento por complexos. A comparação do pensamento em pessoas com esquizofrenia com os vários estágios genéticos do pensamento por complexos estabelece um critério psicológico para avaliação do grau de cisão e regressão no paciente com esquizofrenia.

Vigotski critica a comparação do pensamento por complexos de pessoas com esquizofrenia com o pensamento de povos tribais, com os sonhos ou com o processo intelectual em animais inferiores. $\mathrm{O}$ autor aponta que estas comparações negligenciam os graus do desenvolvimento psicogenético, pois o pensamento por complexos observado em 
pacientes com esquizofrenia é a etapa mais próxima do pensamento conceitual, precedendo-o imediatamente.

Quando um conceito e um complexo referem-se ao mesmo objeto, o complexo pode ser denominado como um pseudo-conceito, que é o elemento básico do pensamento infantil e da esquizofrenia. Os complexos surgem antes do que os conceitos na ontogênese, formando sua estrutura básica, a exemplo do desenvolvimento estratificado do sistema nervoso central. Assim, o pensamento por complexos não é uma forma de pensamento típica da esquizofrenia, mas uma forma mais antiga que está presente de forma latente na psique do paciente, surgindo quando os processos intelectuais superiores se deterioram em função da doença. A percepção na esquizofrenia também sofre alterações, deixando de se articular com o pensamento visual. Para Vigotski, os "fatores significativos aqui não são o embotamento emocional e o desaparecimento da riqueza e da variedade de expressão emocional, mas a separação destas expressões emocionais dos conceitos com os quais são intimamente associadas" (ibidem, p.14). Vigotski defende que o distúrbio da vida emocional é somente parte de um distúrbio no campo da formação de conceitos. O autor assinala que os distúrbios na formação de conceitos não são a causa da esquizofrenia, mas um resultado desta.

Vigotski também discute no texto as supostas relações entre a esquizofrenia e o sono, citando Pavlov e a ideia de que a esquizofrenia resultaria de uma insuficiência nos processos de inibição interna. $\mathrm{O}$ interesse do autor em tal teoria é a tentativa de buscar uma explicação orgânica para a esquizofrenia para articular-se com a hipótese psicológica sobre a doença. A perda de contato com a realidade, como no caso do autismo e da esquizofrenia, resultaria de determinadas condições do sistema nervoso, tendo um fundamento biológico. No caso da esquizofrenia, essa perda de contato seria uma espécie de reação do organismo diante desta debilidade do sistema nervoso central. A partir dessas colocações, Vigotski tira algumas conclusões considerando a origem social das funções psicológicas superiores, observando que em estados como o sono e a esquizofrenia ocorre uma interrupção do contato com a base social da personalidade, o que poderia explicar a diminuição da capacidade de formação de conceitos, bem como os sintomas da esquizofrenia.

É curioso observar que, nos dias atuais, o relacionamento entre psicose e cognição ainda não foi adequadamente explorado, conforme apontam Bonner-Jackson et al. (2010). Os autores afirmam que, apesar de ser observado que indivíduos com esquizofrenia apresentam em certa medida déficits cognitivos, ainda se sabe pouco sobre sua influência ao longo da 
vida e da evolução da doença. Em um estudo longitudinal realizado pelos autores durante vinte anos com 244 pacientes psiquiátricos (com esquizofrenia e outros distúrbios psicóticos), focando dois aspectos da cognição (velocidade de processamento e habilidade de acessar conhecimento geral), foi identificado que indivíduos com esquizofrenia apresentavam um desempenho empobrecido em relação aos outros pacientes, o que levou os autores a concluírem que há uma associação entre disfunção cognitiva relativa e psicose. Sobre isso, é interessante destacar o interesse de Vigotski nesta relação já na década de 1930, bem como o fato deste campo de estudo sobre cognição e doença mental permanecer em certa medida pouco explorado após oitenta anos decorridos do interesse inicial de Vigotski sobre o tema. Parece ser mais um indicador do quanto há ainda a ser explorado nas sementes lançadas pelo psicólogo bielorrusso.

\subsubsection{Para o problema da demência no Mal de Pick (1934)}

O texto foi escrito por Vigotski em colaboração com dois autores, Samukhin e Birenbaum, e foi escrito a partir do estudo do caso clínico de um dentista de 51 anos de idade, diagnosticado com a Doença de Pick, de acordo com o apontado por Meshcheryakov (2007). Ainda segundo este autor, o paciente era capaz de memorizar algumas palavras através da repetição, mas não conseguia lembrá-la fazendo uma associação com uma figura apresentada em cartão, cujo objetivo era levá-lo à evocação da palavra correspondente, e ao invés disso nomeando o objeto apresentado na figura, em experimentos semelhantes aos realizados por Vigotski com crianças. Meshcheryakov (2007) aponta que o maior interesse de Vigotski estava no emprego de recursos de mediação externo em relação com a idade do paciente.

Infelizmente, este texto não foi analisado nesta tese, devido ao fato do mesmo ter sido encontrado apenas em russo. No entanto, considerou-se importante manter esta referência ao mesmo, para destacar a importância de ser estudado em outras oportunidades, principalmente com base no que referem Van der Veer e Valsiner (2001), ou seja, de que a demência é apresentada como uma reorganização estrutural em consonância com os princípios gerais do funcionamento psicológico, indo ao encontro das proposições vigotskianas acerca da gênese e desintegração das funções psíquicas. 


\section{DISCUSSÃO}

Os pesquisadores têm uma tarefa fundamental: converter o objeto em movimento, e ofossilizado em processo. (Vigotski $\left.i^{47}\right)$

Após este percurso pela obra selecionada de Vigotski, cabe tecer algumas considerações sobre as ideias que emergem a partir da elaboração da teoria aqui apresentada.

Uma ressalva inicial deve ser feita no que se refere à questão da ausência de definições de termos básicos da psicologia histórico-cultural por Vigotski, o que acrescenta uma dificuldade a mais para o pesquisador da sua obra (conforme observado por mim na apresentação de $O$ problema do desenvolvimento e da desintegração das funções psíquicas superiores). Vigotski argumenta que definições claras dos termos não são elementos dados a priori na pesquisa científica, mas que devem surgir do exame das questões analisadas (VYGOTSKI, 1934/2008). Em outro texto (A consciência como problema da psicologia do comportamento, 1925/2004, p.85), Vigotski parece avesso a definições, argumentando que é a partir de algumas ideias iniciais que se inicia o estudo mais aprofundado, uma vez que a psicologia como ciência não permitiria outra forma de abordagem naquele momento:

O estado em que se encontra nossa ciência ainda a mantém muito afastada da formula final de um teorema geométrico que coroe o último argumento: como queríamos demonstrar. Cremos que no momento atual ainda continua importante definir com precisão o que é que se deve demonstrar para depois nos dedicarmos a demonstrá-lo: primeiro, formular a tarefa; depois, resolvê-la.

\footnotetext{
${ }^{47}$ No original: "Los investigadores tienen planteada una tarea fundamental ya mencionada por nosotros: la de converter el objeto movimiento y el fosilizado en proceso". In: Historia del desarrollo de las funciones psíquicas superiores (VYGOTSKI, 1931-2000, p.105).
} 
Pino (2005) sugere que, na falta de definições do autor, o pesquisador confronte aquelas que puder esboçar com o princípio norteador da psicologia histórico-cultural sempre que haja dúvida, que é o método materialista histórico-dialético, tomado como contexto e arcabouço da produção teórica de Vigotski. A partir dessa delimitação, sempre que se julgar necessário serão apresentadas aqui possíveis interpretações para o significado de alguns termos recorrentes no decorrer desta análise.

O primeiro aspecto a destacar a respeito da psicologia histórico-cultural enquanto teoria é o seu caráter monista. Em Os métodos de investigação reflexológicos e psicológicos (1924-1926/2004), ao defender a consciência como o objeto de estudo por excelência da psicologia, Vigotski baseia-se na premissa da concepção monista do fenômeno corpo-mente. Em A psique, a consciência, o inconsciente (1930b/2004), argumenta que os processos neurofisiológicos e psíquicos se dão de forma indissociável. Para designar a ambos em sua atuação conjunta e imbricada, adota a definição de processos psicológicos. É importante ter em mente, portanto, que o termo psicológico em Vigotski corresponde ao termo psicofisiológico, o que aponta que, por definição, não há espaço para atribuir motivações dualistas na obra vigotskiana, sobretudo no que se refere à metodologia. Para o autor,

o objeto da psicologia não é constituído pelo fenômeno psicológico neutro, mas pelo fenômeno psicofisiológico integral único, que convencionalmente denominamos fenômeno psicológico. (VIGOTSKI, 1930b/2004, p.157)

Note-se que o termo psicológico recebe uma definição bem clara do autor, não havendo nesse caso muita margem para dúvida, como já foi aqui comentado a respeito de outros termos utilizados por ele. Em seu esboço O problema mente-corpo, (1932/1977), Vigotski comenta que o paralelismo psicofísico resulta de um compromisso entre o pensamento físico e matemático característico das ciências naturais e o entendimento précientífico e religioso que persiste na pesquisa em psicologia, sendo também um dos fatores da crise dessa disciplina (VIGOTSKI, 1927/2004). Advoga também que falar em uma suposta interação entre mente e corpo é uma forma de paralelismo. Pondera que isso advém da falha das teorias psicológicas em não abordarem a consciência relacionada ao seu desenvolvimento histórico, pois a consciência advém, para o autor, da experiência social.

Uma vez que as abordagens dualistas articulam-se com as abordagens idealistas, também não pode haver dúvida de que se trata aqui de uma abordagem materialista. Esta posição é muito clara e anunciada logo de início por Vigotski (1925/2004). 
De acordo com Bottomore (1998), o conceito de materialismo tem sido desenvolvido de formas diversas na filosofia marxista. Um princípio do materialismo filosófico ontológico postula que o ser social depende do ser biológico, e emerge a partir dele. Pressupõe-se, portanto, que qualquer forma de consciência parte da existência real e concreta do homem, a partir de sua experiência social e atividade transformadora da natureza ou trabalho.

O termo psique também é definido por Vigotski com pressupostos materialistas. Para ele, a psique é parte da natureza, e sua origem está ligada às funções da matéria altamente organizada do cérebro, e surgiu no processo de desenvolvimento; é a "expressão subjetiva desses mesmos processos, como uma faceta especial, uma característica qualitativa especial das funções superiores do cérebro (VIGOTSKI, 1930b/2004, p.144). Novamente em confronto com uma visão interacionista, Vigotski assinala que os fenômenos psíquicos não influem sobre os processos cerebrais, assim como "não dá para separar o sol do seu calor" (ibidem, p.147). Portanto, não se trata de nenhum tipo de relação entre psique e cérebro, pois qualquer tipo de relação seria uma hipótese dualista.

Como já foi comentado anteriormente, no Manuscrito de 1929 (VIGOTSKI, 1929/2000) Vigotski critica a analogia feita por Pavlov da relação entre cérebro e corpo como uma central telefônica e a telefonista. Vigotski defende que não é possível entender o comportamento de forma isolada da pessoa que se comporta, ou o telefone sem a telefonista.

Uma possível explicação para a visão dualista do ser humano estaria na falta de compreensão sobre o processo de desenvolvimento humano. Para Vigotski, o desenvolvimento humano se dá em duas linhas, o desenvolvimento orgânico, relacionado à maturação biológica, e o desenvolvimento cultural, ou seja, a apropriação das formas de pensamento culturais. Contudo, estas duas linhas não podem se separar, a não ser em um esforço teórico para estudá-las. Elas se desenvolvem juntas, e não se pode distinguir onde uma começa e a outra termina, constituindo assim duas faces de um processo único. Imaginar um organismo humano que se desenvolve apenas do ponto de vista biológico, sem contato social humano, é uma abstração. Mesmo se tomarem-se casos de crescimento isolado de indivíduos em relação à sociedade humana, como os clássicos e controversos relatos das “crianças selvagens” Amala e Kamala, encontradas na Índia em 1920, e de Victor de Aveyron, encontrado na França em 1798, e sendo considerados seus prejuízos e prognósticos pessimistas quando passaram a fazer parte da cultura humana, tais crianças receberam em 
dado momento de seu desenvolvimento algum tipo de cuidado, ainda que insuficiente, uma vez que o ser humano é biologicamente social - ou seja, se não for cuidado ao nascer, não sobreviverá, e se não for inserido imediatamente numa cultura humana, terá prejuízos irreversíveis na sua socialização e no desenvolvimento da linguagem, entre outros aspectos.

Desta forma, pretender separar esses dois ramos para atribuir um suposto enfoque dualista a Vigotski é improcedente, principalmente se considerado à luz do materialismo histórico-dialético, como sugerido por Pino (2005). Em A psique, a consciência, o inconsciente (VIGOTSKI, 1930b/2004), Vigotski explica que o enfoque dialético da psicologia baseia-se na unidade dos processos psíquicos e fisiológicos. Para ele, é um equívoco procurar os processos psíquicos como produtos derivados dos processos nervosos, como se pudessem ser produzidos de forma isolada. Vigotski defende que o que se deve buscar são "determinadas condições conjuntas no sistema nervoso e no comportamento, onde surgem os processos psicológicos integrais" (ibidem, p.152-153).

Em seu texto O pensamento na esquizofrenia (VIGOTSKI, 1931/2008), ao mencionar estudos que buscam relacionar os mecanismos dessa patologia com os do sono, o autor reconhece que o valor dessas iniciativas reside na tentativa de buscar uma explicação orgânica para a esquizofrenia, ainda que possa apontar-lhes algumas falhas - o que mostra a valorização dada por Vigotski à busca de uma fundamentação biológica para os fenômenos psíquicos.

No Manuscrito de 1929 (VIGOTSKI, 1929/2000), Vigotski usa com certa frequência a contraposição de termos "cérebro" e "pessoa", como se se tratasse de dois elementos diferenciados, de um lado o cérebro, e de outro a pessoa (observe-se em trechos como: "entre eu e minha memória", "Se S1 e S2 estão em uma pessoa, então na operação sempre há dois objetos: cérebro e objeto da tarefa psicológica", "Difícil é quando o objeto é o próprio cérebro"). Isso poderia ser interpretado como uma colocação idealista, baseando-se na existência de algo supra-cerebral, ou extra-cerebral, ou na existência de uma pessoa destacada do cérebro e vice-versa, mas o conteúdo do texto e o rigor metodológico do autor não alimentam tal hipótese. No mesmo texto, o autor conclui que a questão da consciência não se resume à relação entre áreas cerebrais distintas, mas está no controle destas áreas por uma personalidade de origem social encarnada no indivíduo, o que deixa clara sua concepção monista, não admitindo portanto uma separação entre mente e cérebro. Pode-se inferir que esta forma de expressão deve-se ao fato do Manuscrito ser um esboço pessoal, não decupado 
para a publicação. Na História do desenvolvimento das funções psíquicas superiores (1931/2000), texto onde o autor aprofunda e desenvolve os conceitos esboçados no Manuscrito de 1929, não se observa tais colocações, o que possivelmente se deve a uma revisão mais cuidadosa pelo autor.

Não pode haver dúvida, portanto, quanto ao caráter monista e materialista da psicologia histórico-cultural proposta por Vigotski. Van der Veer e Valsiner (2000) se perguntam se uma forma de dualismo não persistiria na distinção feita por Vigotski entre processos psicológicos inferiores e superiores. Pelos motivos acima expostos, pondera-se que se trata de uma compreensão parcial, sem levar em consideração o método materialista histórico-dialético em que Vigotski fundamentou suas proposições, e a partir do qual colocou como uma exigência metodológica da psicologia histórico-cultural a unidade entre os processos psíquicos e fisiológicos. Moll (2002, p.47) reflete sobre o risco em que incorrem aqueles pouco familiarizados com o arcabouço filosófico da obra vigotskiana em atribuir a ele um dualismo de natureza cartesiana, esquecendo-se de que, na abordagem sistêmica do autor, “os processos psicológicos são uma função da atividade cerebral e não uma aparição autônoma".

Outra probabilidade que pode alimentar esse tipo de dúvida sobre o caráter monista da psicologia histórico-cultural é a já mencionada indefinição conceitual de Vigotski relacionada a alguns pontos da teoria que acabam por fomentar esse tipo de questão, como por exemplo a exata definição de funções psicológicas inferiores e superiores. A busca da construção dessas definições em um processo dialético de análise, relacionado à percepção do momento histórico da psicologia que aqui se colocou, aliados ao fato de tratar-se de uma obra inconclusa, que não teve o benefício da revisão amadurecida e rigorosa do autor parecem explicações mais plausíveis do que uma suposta inconsistência teórica de Vigotski.

Nesse sentido, Pino (2005) faz um esforço para definir função, um dos conceitos mais elementares e nebulosos de Vigotski. Pino (2005) aponta inicialmente o termo e seu significado como ato de funcionar relacionado ao resultado desse ato, e remetido ao verbo funcionar. Também aponta que o termo função com dois sentidos: o sociológico, onde se refere à posição social à qual se associam determinados papéis e o matemático, ou correspondência entre elementos de dois conjuntos matemáticos. O sentido sociológico, no qual funções implicam em relações sociais, também levanta a necessidade de definir estas últimas. Pino (2005, p.103) argumenta que as relações sociais estão relacionadas com a 
pessoa enquanto unidade bio-cultural que funciona de diferentes maneiras, apontando que Vigotski considerava que é um equívoco atribuir ao cérebro atividades que são função da pessoa, como sonhar (eu tive um sonho lindo), pensar (tive uma ideia) ou sofrer (estou com dor de cabeça). Ainda que estes exemplos tratem de funções comuns a todas as pessoas, seu conteúdo varia entre as pessoas e na própria pessoa. Assim, Pino (2005) conclui que "não é o cérebro que sonha ou pensa, mas a pessoa", e que "sonhar e pensar são funções da pessoa, porque só ela pode sonhar ou pensar isso ou aquilo, desta ou daquela maneira, em função da posição que ela ocupa no campo das suas relações sociais" (p.104).

Pino (2005) aponta também que as funções psicológicas superiores são sociais, uma vez que emergem a partir das condições de existência criadas pelo homem. As condições inatas do ser humano são os alicerces para as relações sociais, mas não as determinam. Pino (2005, p.106) não fala de relações sociais no sentido de sociabilidade, ideologicamente neutras, e sim um sistema de posições e papéis que se concretizam em práticas sociais ou formas culturais de pensar e agir daquelas pessoas que integram determinada formação social.

\footnotetext{
Pode-se concluir que as funções mentais superiores não são simples transposição no plano pessoal das relações sociais, mas a conversão, no plano da pessoa, da significação que tem para ela essas relações, com as posições que nelas ocupa e os papeis ou funções que delas decorrem e se concretizam nas práticas sociais em que está inserida (PINO, 2005, p.107).
}

Em Psicologia educacional [paidologia] do adolescente (1931a/1997), Vigotski apresenta três leis fundamentais no desenvolvimento do sistema nervoso: 1) Conservação dos centros inferiores como níveis isolados; 2) Passagem de funções a níveis superiores; 3) Emancipação de centros inferiores em caso de danos ao sistema nervoso. Novamente, cabe apontar que a expressão "centros inferiores como níveis isolados" deve ser interpretada com cuidado, e não ser tomada como uma colocação idealista. Na sequência do mesmo texto, Vigotski aponta que, à medida que se desenvolvem os centros ou estruturas superiores, os centros ou estruturas inferiores cedem uma parte essencial de suas antigas funções a estas novas funções, transpondo-as a estas instâncias superiores, que passam a ser responsáveis pelas tarefas de adaptação, anteriormente executadas pelas funções inferiores. Por centros inferiores e centros superiores o autor entende as estruturas cerebrais relacionadas com as funções psicológicas inferiores e superiores, respectivamente. Assim, os centros inferiores não são abandonados na medida em que se formam os centros superiores, mas funcionam junto com eles como instâncias subordinadas a estas instâncias superiores (ou seja, mais 
recentes na história do desenvolvimento), e que não podem ser estudadas separadamente em um sistema nervoso não danificado. Portanto, este conceito colocado de forma aparentemente confusa fica mais claro se tomar-se o termo conversão proposto por Pino (2005) para seu esclarecimento.

Poder-se-ia acrescentar a este considerável esforço de Pino mais uma definição de função, que é aquela relacionada ao significado evolutivo do termo. Por exemplo, exige uma razão evolutiva para que predadores tenham um campo focal mais reduzido e preciso, localizado à frente, enquanto presas têm um campo focal bilateral, assim como existe uma razão para existir uma terceira pálpebra no gato ou sobrancelhas num rosto humano. Tais características têm - ou, em alguns casos, tinham - uma função determinada, um uso que se explica pelo caráter evolutivo das espécies. Assim, as funções psicológicas superiores podem estar relacionadas com a evolução do homem enquanto ser social, havendo uma razão evolutiva para que elas existam, e provavelmente relacionada com a característica social da espécie humana.

Segue-se como conclusão que o principal significado do conceito vigotskiano de função psicológica superior seja seu caráter exclusivamente humano, ou seja, são aquelas que caracterizam a humanidade. A esta definição contrapõe-se a de função psicológica inferior, elementar, básica ou primária, que são compartilhadas com os primatas em certo nível observe-se com o conceito de Köhler de "idade do chimpanzé", referido por Vigotski em História do desenvolvimento das funções psíquicas superiores (ibidem, p.38): "um bebê de seis meses é mais dependente que um pintainho, aos dez meses não sabe andar nem se alimenta sozinho, mas é justamente neste período que passa pela 'idade do chimpanzé' e maneja pela primeira vez as ferramentas $\left.{ }^{48 "}\right)$. As funções psicológicas inferiores são o arcabouço sobre o qual se erguem as funções psicológicas típicas da espécie humana, que são as funções psicológicas superiores.

Pensando-se em um exemplo do campo da neurociência, por meio de estudos contemporâneos, sabe-se que primatas possuem regiões do cérebro com neurônios especializados na detecção de faces, assim como os humanos. Segundo Gazzaniga, Ivry e

\footnotetext{
${ }^{48}$ No original: "Um bebé de 6 meses es más desvalido que un polluelo; a los 10 meses aún no sabe andar ni alimentarse por si solo; sin embargo, durante estos meses es cuando el bebé pasa por la 'edad del chimpancé' y maneja por primera vez la ferramienta".
} 
Mangun (2006), a existência de um módulo cerebral especificamente voltado para a percepção de faces pode ser hipoteticamente justificável do ponto de vista evolutivo. Os autores relatam que determinados pacientes neurológicos apresentam prejuízo na percepção de faces isoladamente, o que é intrigante dada a grande capacidade de memorização de fisionomias apresentada pelos humanos. O déficit específico na capacidade de reconhecer fisionomias, cuja etiologia não possa ser caracterizada por algum tipo de deterioração da função intelectual, é identificado pelo nome de prosopagnosia. Em estudos realizados com macacos (McCARTHY et al., 1997, apud GAZZANIGA, IVRY E MANGUN, 2006), observou-se que neurônios localizados no giro fusiforme do hemisfério direito respondiam mais fortemente a faces em relação a objetos inanimados ou texturas, o que é consistente com os dados observados em humanos com lesões nesta área. Outros pesquisadores, como Haxby (apud GAZZANIGA, IVRY E MANGUN, 2006), defendem que o reconhecimento de faces pode estar relacionado a múltiplas áreas cerebrais, podendo-se admitir que a área fusiforme pode ser importante para diferenciar faces de outros estímulos, mas não entre faces diferentes. Segundo Cohen (apud GAZZANIGA, IVRY E MANGUN, 2006), na visão distribuída as demais áreas cerebrais ativadas dariam "cor" e "forma" a uma face específica, distinguindo-a das demais. Lent (2011), ao comentar os experimentos de Tsao e colaboradores com macacos sobre reconhecimento de faces, argumenta que não se pode falar em neurônios especializados em reconhecer uma face específica, sendo mais plausível que o reconhecimento de faces se dá pela coordenação de neurônios especializados em faces, através de uma distribuição agregada. A partir destes dados, pode-se admitir que, no caso do ser humano, a experiência cultural moldará biologicamente a expressão desses neurônios, ao ponto em que adquiram um extremo refinamento perceptivo.

$\mathrm{O}$ mesmo pode ser dito em relação à memória eidética ou para imagens. Uma pessoa criada em uma cultura ocidental poderá facilmente reconhecer um cubo, que é uma forma tridimensional culturalmente aprendida, em um desenho bidimensional de seis traços como o da figura abaixo, e poderá, inclusive, reconhecer duas diferentes perspectivas nesse cubo. 

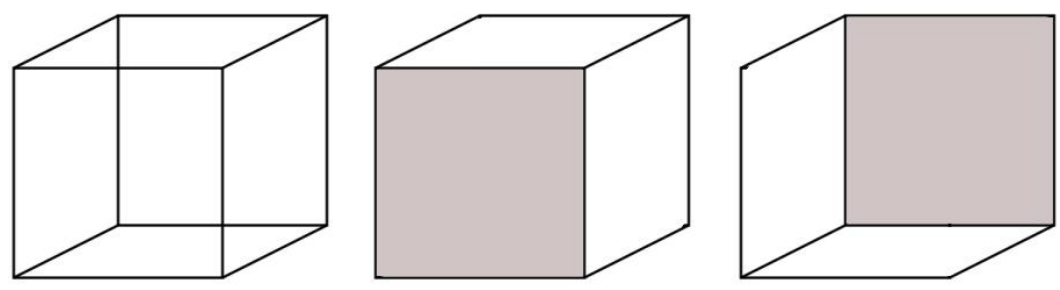

Figura 4 - Representação bidimensional de um cubo e as duas vistas, de baixo e de cima (Fenômeno de Necker, adaptado de BALDO; HADDAD, 2003)

Isso ocorre porque, durante sua experiência cultural, o circuito nervoso responsável por enxergar cubos se estabeleceu, tanto em experiências escolares com o conteúdo de geometria quanto em experiências no cotidiano, que capacitam essa pessoa a perceber cubos nos produtos humanos, desde meros rabiscos até elevadores, maços de cigarro e outros objetos produzidos pelo trabalho nesta determinada sociedade. Como apontam Baldo e Haddad (2003), os mecanismos perceptivos do ser humano foram moldados no decorrer do processo evolutivo e selecionados de acordo com seu valor adaptativo. Desta forma, a construção da percepção própria de cada humano resulta da interação entre a bagagem genética herdada e a ação de cada indivíduo em seu meio.

Assim, seria equivocado interpretar que Vigotski postulou a convivência de uma função psicológica elementar ao lado de uma função psicológica superior enquanto elementos isolados ou mesmo articulados na consciência, embora se possa descuidadamente concluir isso a partir de uma leitura não dialética de sua obra. Na verdade, o fundamento do conceito é a transformação sofrida pela função psicológica elementar que leva à emergência da função psicológica superior, a tal ponto que Pino (2005) defende o termo conversão em lugar de internalização, pois não se trata de uma mera adição, mas de uma mudança de estado.

Um exemplo bastante esclarecedor deste processo de conversão é o efeito Stroop, conceito que derivou das experiências de John Ridley Stroop (1935) sobre a atenção seletiva (STERNBERG, 2010). Este conceito refere-se à dificuldade psicológica de prestar atenção à cor da tinta em que uma palavra está impressa, ignorando deliberadamente o significado da palavra - por exemplo, pede-se que a pessoa leia a palavra "VERDE" impressa na cor vermelha. Isso ocorre porque ler uma palavra é um processo automatizado em adultos leitores. Seguindo Vigotski, poder-se-ia dizer que a leitura, um processo culturalmente aprendido, transformou a função psicológica elementar da atenção na função psicológica 
superior de atenção seletiva, justamente pelo aprendizado da leitura e sua automatização. Assim, nesse indivíduo leitor, sua atenção na tarefa de Stroop não funcionará da mesma forma como funcionaria caso ele não dominasse o processo da leitura, ou não pertencesse a uma cultura letrada - neste caso, inclusive, nem poderia realizar a tarefa. Sua função psicológica elementar de atenção converteu-se na função psicológica superior de atenção seletiva.

É interessante apresentar neste ponto a definição de função psicológica superior do ponto de vista neurológico. Bérubé (apud COSTA, 2011, p.1) apresenta a seguinte definição daquilo que denomina como atividades nervosas superiores ou funções cerebrais superiores:

Capacidades que mobilizam: (a) um sistema de organização da informação perceptual, (b) a rememoração da aprendizagem anterior, (c) os mecanismos córticosubcorticais que sustentam o pensamento e (d) a capacidade de tratar duas ou mais informações ou eventos simultaneamente.

A partir disso, Costa (2011) enfatiza que tais funções diferenciam a espécie humana das demais, uma vez que alcançaram um desenvolvimento no ser humano que permite a ele modificar o ambiente e as condições em que vivem de forma absolutamente diferenciada de outras espécies, incluindo outros primatas. A autora argumenta que em um período de tempo relativamente curto em termos evolutivos, a capacidade craniana humana triplicou de tamanho, o que provavelmente decorreu da necessidade de sobreviver e alimentar-se em ambientes hostis. A autora refere que "as funções cerebrais superiores cresceram em paralelo com o aumento do tamanho cerebral e terminaram conferindo à nossa espécie as particularidades que hoje a caracterizam e a diferenciam das outras espécies" (p.1). Tais funções têm no córtex cerebral sua localização anatômica e funcional, região cerebral que contém tanto neurônios relacionados com a manutenção de funções básicas como as motoras, sensitivo-motoras, auditivas ou visuais, quanto aqueles envolvidos na manutenção de funções elaboradas como a memória, a linguagem, o raciocínio abstrato ou atividades gestuais, segundo Costa (ibidem, p.1). A autora explica ainda que as funções cerebrais superiores "não se encontram localizadas em centros isolados do cérebro, mas se acham integradas em grupos de regiões que formam uma rede cerebral baseadas em interconexões neurais, isto é, as funções cerebrais têm uma distribuição interconectada, formando uma rede integrada" (ibidem, p.1). É significativo observar que, nas definições apresentadas pela autora a partir de conceitos neurológicos, destaca-se o papel evolutivo e a especificidade humana na 
origem das funções cerebrais superiores, o que está em consonância com a acepção vigotskiana do conceito.

Outra questão fundamental no pensamento de Vigotski (talvez a mais importante), e que está intrinsecamente ligada à questão do cérebro, é o conceito de consciência.

Desde o marco de seu primeiro trabalho no campo da psicologia (sua palestra do Segundo Congresso de 1924), Vigotski faz uma defesa veemente da consciência enquanto objeto de estudo por excelência da psicologia, definindo como o objeto da psicologia histórico-cultural (VIGOTSKI, 1924-1926/2004) bem como sua natureza psicológica (VIGOTSKI, 1925/2004). Esta defesa é talvez o argumento mais forte em favor da afirmação do caráter monista da psicologia histórico-cultural, uma vez que Vigotski entende a consciência como um produto da evolução do cérebro (VIGOTSKI, 1925/2004).

Em A psique, a consciência e o inconsciente (VIGOTSKI, 1930b/2004), Vigotski refere-se ao apontamento de Pavlov (acertado, em sua opinião) segundo o qual a consciência seria uma espécie de mancha luminosa que se move nos hemisférios cerebrais de acordo com a excitação nervosa. Vigotski entendia que é necessário buscar as condições do sistema nervoso e do comportamento como um conjunto a partir do qual surgem os processos psicológicos, e não buscar os processos psicológicos como um resultado dos processos nervosos (ibidem, p.152-153), pois nesta segunda condição se pressupõe uma dualidade entre corpo/processos nervosos por um lado e comportamento e mente/processos psíquicos por outro. Não é esse o ponto de vista defendido pela psicologia histórico cultural, e sim uma síntese entre esses aspectos.

Para Vigotski, a consciência é uma estrutura complexa do comportamento, envolvendo sua duplicação. O conceito de duplicação do comportamento refere-se ao fato de o ser humano diferenciar-se dos animais pela possibilidade de planejar seu comportamento, portanto sua ação é uma duplicação desse planejamento anterior. Vigotski ilustra tal conceito com o exemplo de Marx acerca das aranhas e abelhas, comparadas ao tecelão e ao arquiteto ${ }^{49}$.

\footnotetext{
${ }^{49}$ Cf. Marx: "Uma aranha executa operações semelhantes às do tecelão, e a abelha supera mais de um arquiteto ao construir sua colmeia. Mas o que distingue o pior arquiteto da melhor abelha é que ele figura na mente sua construção antes de transformá-la em realidade. No fim do processo do trabalho aparece um resultado que já existia antes idealmente na imaginação do trabalhador. Ele não transforma apenas o material sobre o qual opera; ele imprime ao material o projeto que tinha conscientemente em mira, o qual constitui a lei determinante do seu modo de operar e ao qual tem de subordinar sua vontade." (MARX, 1867).
} 
Com isso, Vigotski quis enfatizar o caráter específico do comportamento humano em comparação com uma mera reação em resultado de estímulos. Nesse sentido, o comportamento humano é infinitamente mais complexo do que o animal.

Outro conceito vigotskiano relacionado é o de Homo duplex, no sentido que a consciência humana decorre de experiências sociais internalizadas, e que portanto foram vividas inicialmente como uma relação entre duas pessoas, e a partir de sua internalização, passam a ser vivida como uma relação entre centros corticais, como nos processos de evocação da memória. Assim, para Vigotski, a origem da consciência é social (VIGOTSKI, 1924-1926/2004).

A origem social da consciência para Vigotski não deve levar à ideia de que ela se baseie em outro substrato que não o neurofisiológico. O autor defende esse ponto de vista no texto A consciência como problema da psicologia do comportamento (1925/2004). Para ele, a consciência deve ser compreendida como "um sistema de mecanismos transmissores de uns reflexos para outros, que funciona perfeitamente em todo momento consciente" (ibidem, p.71). Partindo desse mecanismo, para Vigotski "cabe admitir que no organismo não há outros processos além das reações." (ibidem, p.73). São as interações entre reflexos que estariam na base de uma explicação para a consciência:

A psicologia deve, pois, formular e resolver o problema da consciência na perspectiva de considerá-lo como interação, reflexão, excitação recíproca de diferentes sistemas de reflexos. É consciente o que se transmite a outros sistemas na qualidade de excitante e provoca neles uma resposta (ibidem, p.71-72).

Vigotski afirma que a diferença entre consciência e mundo externo está em que a consciência é o contexto dos reflexos, enquanto o mundo é o contexto dos excitantes. É importante ressaltar que essas afirmações de Vigotski não fazem dele um reflexologista ou um behaviorista. Ao contrário destes, Vigotski faz questão de entrar na "caixa preta"50" deixada intocada por eles, que é a seara dos fenômenos mentais não diretamente observáveis. Ou seja, ele está utilizando conceitos neurofisiológicos como reações e reflexos para tentar

\footnotetext{
${ }^{50}$ Para o behaviorismo, a consciência humana funcionaria como uma espécie de caixa preta, cuja impossibilidade de conhecimento direciona o pesquisador para a análise do comportamento observável. O conceito de caixa preta tem origem na teoria dos sistemas, e foi utilizado por Latour em sua reflexão sobre a ciência, onde conceitua a caixa preta como um dispositivo experimental que é tomado como estável, funcionando como um ponto de passagem obrigatório em uma dada
} 
explicar a consciência humana enquanto um fenômeno material. O que se está discutindo aqui são elementos concretos do cérebro humano, como reações e reflexo, no sentido de células componentes de todo comportamento por mais complexo que seja.

Em O problema do desenvolvimento cultural da criança, (1929/2008), Vigotski ressalva que o os estímulos mediados e imediatos são equivalentes do ponto de vista cerebral, ou seja, as conexões AX e BX são culturais e do mesmo tipo que as conexões reflexas ou incondicionadas $\mathrm{AB}$. Portanto, o desenvolvimento cultural não cria um outro tipo de conexão neural ou se dá a partir de um outro tipo de substância, e sim pela crescente complexidade das conexões básicas existentes, que são modeladas pela experiência social.

A psicologia histórico-cultural ergueu-se sobre a premissa da anterioridade da realidade material relativamente ao psiquismo, portanto a base material do psiquismo é pressuposto da psicologia histórico-cultural. Devido a isso, Vigotski nunca rejeitou a ideia de que os reflexos condicionados são a base do comportamento, mas nem por isso deixou de criticar o reducionismo da reflexologia, pois suas explicações para o psiquismo humano eram insuficientes e inaceitáveis (TEIXEIRA, 2005). Para ele, era clara a incapacidade da reflexologia em explicar adequadamente a consciência (RIVIÈRE, 1984).

Em seus primeiros trabalhos, Vigotski conceitua a consciência como um "sistema de transmissão de reflexos". Mas a necessidade de definir mais precisamente a natureza desta transmissão levou-o a contrapor-se à perspectiva reducionista da consciência, limitada a um repertório de reflexos condicionados.

Em A consciência como problema da psicologia do comportamento (VIGOTSKI, 1925/2004), Vigotski declara objetivamente que o reflexo não é uma explicação universal, e em História do desenvolvimento das funções psíquicas superiores (VYGOTSKI, 1931/2000) afirma que o condicionamento reflexo não é suficiente para explicar o comportamento humano do ponto de vista psicológico, uma vez que este é orientado pela experiência histórica, e não somente pelos reflexos condicionados e incondicionados tomados de forma isolada.

Assim, Vigotski parte inicialmente de uma concepção de consciência que se aproximava da noção dos reflexos de Bekterev (apesar de não ter uma identidade com ela) e 
vai ao encontro de uma concepção mais próxima da teoria do reflexo como conceituada por Lenin, segundo a qual o "conhecimento é a reflexão da natureza pelo homem. Mas isto não é um reflexo simples, nem imediato, nem completo, mas o processo de uma série de abstrações, a formação e desenvolvimento de conceitos, leis, etc. [...] O conhecimento do homem não apenas reflete o mundo objetivo, mas o cria" (LENIN apud PEREIRA, 2004). A principal diferença entre os dois conceitos está na ideia do reflexo do real de Lenin como algo que implica o trabalho da consciência, e não como receptor passivo de impressões e sensações. Vigotski formula o conceito de atividade para descrever justamente isso: uma ação que não se baseia em mera resposta ao meio, mas que contém um componente de transformação desse meio com o auxílio de instrumentos (RIVIÈRE, 1984).

Segundo Teixeira (2005), na análise desta questão devem ser considerados três aspectos:

1) Vigotski recusou o esquema E-R (estímulo-resposta) porque tal projeto caracteriza o psiquismo como algo estático ou um mero repositório de respostas aos estímulos ambientais, já que, para o autor, o humano não somente reage ao ambiente externo, mas também ao meio criado pela sua própria atividade;

2) O conceito de reflexo incorporado pela psicologia histórico-cultural não se reduz ao escopo biológico do termo, ou seja, a padrões de reação inatos, e sim está relacionado com o conceito do materialismo histórico-dialético de que a realidade é anterior à consciência. O conhecimento não é um mero reflexo da realidade ou uma simples impressão sensorial, mas sua reelaboração criativa. Trata-se portanto de um reflexo em movimento, e não de um reflexo especular: "o reflexo psíquico é condição para que o sujeito se aproprie [...] de seu comportamento" (TEIXEIRA, 2005, p.95). Portanto, não se trata de um processo onde o indivíduo é passivo;

3) O meio a que o homem reage é muito mais o meio criado pelo próprio homem, através da sua atividade social, do que o meio natural. O psiquismo desenvolvido na relação com o meio social é, portanto, de natureza social também. A psicologia histórico-cultural aceita que o homem reage sob a natureza, todavia, considera fundamentalmente que o sujeito 
se coloca sobre ela e a domina. E justamente nesse processo vai modificando seu próprio psiquismo (TEIXEIRA, 2005, p.97).

Desta forma, apesar da terminologia adotada por Vigotski em seus primeiros trabalhos possa levantar a hipótese de que haveria uma aceitação da teoria reflexa de base biológica pelo autor, tal hipótese é refutada pelos argumentos que levantou em defesa do papel da atividade social na constituição do psiquismo humano, pois esta, ainda que se constitua sobre a base reflexa biológica, não é suficientemente ou integralmente explicada por ela. Pode-se considerar também que a teoria reflexa ou baseada no estímulo-resposta é superada por Vigotski no sentido dialético do termo, através da sua incorporação na fundamentação da psicologia histórico-cultural - tome-se, por exemplo, a sua proposição do esquema estímulo-mediação-resposta (como pode ser visto em VIGOTSKI, 1929/2000).

Nesse ponto, considerou-se pertinente abordar, mesmo que de modo abreviado, algumas contribuições atuais da neurociência ao estudo da consciência, no sentido de discutir algumas convergências e divergências em relação às proposições vigotskianas.

Como apontam Gazzaniga, Ivry e Mangun (2006), apesar da consciência ser um conceito chave para a pesquisa sobre a relação entre cérebro e mente, ou de como o cérebro cria a mente, ainda não há uma definição satisfatória sobre o assunto.

Thompson (2005) refere que se entende como conscientes sensações auditivas, táteis, visuais, olfatórias, notadamente quando se foca a atenção a elas. A ideia de consciência relaciona-se também ao pensamento a respeito de algo ou mesmo a uma fantasia, abrangendo processos verbais implícitos ou pensamentos em palavras, bem como em imagens. A consciência ainda se estende no tempo, tanto em relação ao que acabou de acontecer, quanto à noção de que experiências remotas estão armazenadas na memória e podem ser acessadas, assim como inclui a atenção à situação imediata.

A filosofia da mente, cujo objetivo é a abordagem dos fenômenos mentais, tem se ocupado largamente desta questão. Correntes filosóficas alinhadas com uma visão dualista ou materialista tentaram definir o fenômeno da consciência. São exemplos da primeira o dualismo popular, o dualismo de propriedade, o epifenomenalismo e dualismo de propriedades interacionistas, e da segunda o behaviorismo filosófico, o materialismo reducionista e o funcionalismo (GAZZANIGA; IVRY; MANGUN, 2006). Na neurociência atual, as abordagens materialistas predominam, notadamente na neurociência cognitiva, que 
se ocupa de entender os mecanismos biológicos da cognição. De acordo com Cescon (2009, p.17), “já é quase incontestável a hipótese de que a autoconsciência seja um fenômeno que pertence à evolução da matéria biológica e não seja, pelo contrário, fruto da imaginação do homem que vive numa dimensão metafísica e não tenha nada em comum com a matéria do seu cérebro". Tal posição é corroborada pelos filósofos de orientação materialista. Para John Searle (apud CECON, 2009), filósofo norte-americano, o mistério da consciência será solucionado pela neurobiologia, uma vez que a consciência é um problema empírico, e portanto pode ser abordada de um ponto de vista experimental. Esta também é a posição de Daniel Dennett (apud CECON, 2009), outro destacado filósofo norte-americano, na defesa de uma abordagem do problema da consciência por parte das ciências naturais, tomando-a como um produto da evolução humana.

Blackmore (2005, p.7) enumera algumas características que são reconhecidas como possíveis definições do que é consciência, ainda que não haja muita concordância sobre isso. Segundo a autora, a consciência se liga à ideia de "ser como": se algo ou alguém pode "ser como" um animal, uma pessoa ou um objeto, pode-se dizer que esse algo ou alguém é consciente. A consciência também relaciona-se à experiência de subjetividade ou dos fenômenos, ou seja, como as coisas são para alguém em oposição àquilo que são de forma objetiva. A qualidade intransferível e inefável da experiência subjetiva é chamada de qualia. A vermelhidão do vermelho ou o cheiro de aguarrás são experiências subjetivas; tal conceito não é bem aceito por alguns filósofos, que argumentam que o qualia não existe. Tais ideias exemplificam o que foi chamado pelo filósofo dualista australiano David Chalmers de hard problem, ou problema difícil da consciência: como as experiências subjetivas podem surgir de um cérebro objetivo?

Bennett e Hacker (2005) consideram que a ideia de que a consciência é algo misterioso deriva das confusões conceituais que envolvem sua definição. Apontam ainda que o sujeito da consciência humana é o sujeito, e não o cérebro em si mesmo tomado de forma isolada.

Gazzaniga, Ivry e Mangun (2006) observam que a maior parte dos processos mentais relacionados com a experiência consciente são inconscientes, ou seja, os indivíduos não compreendem os processos envolvidos ao ver determinado objeto, realizar um movimento ou falar algo: "somos conscientes apenas do conteúdo da nossa vida mental, e não dos processos que geram tal conteúdo" (p.678). Como argumento sobre a relação entre os 
aspectos conscientes e inconscientes envolvidos no processo da consciência, os autores citam o intrigante caso da visão cega, onde ocorre visão fora da consciência. Por exemplo, situações em que uma lesão cerebral no hemisfério direito impossibilita o indivíduo de nomear objetos em seu campo visual esquerdo, mas podem fazer julgamentos baseados na percepção destes objetos, percebendo a diferença entre objetos apresentados no campo visual esquerdo e direito, ainda que neguem ter visto os objetos apresentados à esquerda.

Os experimentos realizados com indivíduos com o cérebro dividido ${ }^{51}$ têm obtido alguns achado intrigantes. Por exemplo, ao receber um comando não verbal para o hemisfério direito, a pessoa o realiza sem saber porque está fazendo aquilo, sendo, no entanto, capaz de apresentar uma razão para o comportamento. Tais resultados levaram Gazzaniga e LeDoux a propor o conceito de intérprete, "um sistema que procura por explicações para eventos externos e internos para produzir comportamentos adequados como resposta" (GAZZANIGA; IVRY; MANGUN, 2006, p.690). O intérprete decifra as consequências das adaptações construídas no cérebro e desta forma alimenta o fio da história pessoal do indivíduo.

Campos, Santos e Xavier (1997) apontam que a consciência não deve ser considerada algo único e isolado, e sim como "um conjunto de habilidades mediadas pelo processamento paralelo, porém cooperativo, de informações em diferentes módulos do sistema nervoso". Portanto, ainda que funcione a partir destes módulos, a forma de funcionamento integrada é a responsável pela produção de uma sensação de integridade do processo. O que os autores estão chamando de "processamento paralelo, porém cooperativo" é algo bastante semelhante com a relação de interdependência dialética dos centros cerebrais defendida por Vigotski. O neurocientista Michael S. Gazzaniga declarou em recente entrevista, por ocasião do lançamento de seu livro Who's in charge: free will and the science of the brain (ainda sem título em português, seria algo como Quem está no comando: o livre arbítrio e a ciência do cérebro), que a consciência está relacionada ao sistema cerebral com que alguém está lidando em um dado momento, uma vez que estes mecanismos têm uma ligação estreita com o processamento das sensações. Assim, o funcionamento da consciência

\footnotetext{
${ }^{51} \mathrm{O}$ cérebro é dividido ou calosotomizado através de uma cirurgia conhecida como calosotomia, que secciona o corpo caloso, ou a estrutura formada por fibras nervosas que une os dois hemisférios cerebrais, rompendo a ligação entre eles. É utilizada, por exemplo, nos casos de epilepsia refratária ou de difícil controle por medicamentos, a fim de impedir que os efeitos do foco epilético se propaguem para o outro hemisfério.
} 
seria distribuído pelo cérebro. Apesar da sensação de que a consciência é integrada e unificada, na realidade trata-se de sensações individuais das quais os indivíduos estão conscientes em um dado momento, segundo Gazzaniga (TEPPER, 2011).

No que se refere ao estudo da consciência, Campos, Santos e Xavier (1997) prosseguem criticando a influência da doutrina dualista na psicologia, expressa tanto nas concepções psicanalíticas de mente quanto na alegação da impossibilidade de compreensão destes fenômenos alegada pelo behaviorismo, que é exatamente o cerne da crítica de Vigotski à interpretação do que seria a psicologia materialista na Rússia de 1924. De acordo com Bueno (2002, p.84), “embora o behaviorismo, por cerca de meio século, tenha procurado abolir da psicologia toda referência à consciência, esta noção está de volta sob impacto dos desenvolvimentos da ciência cognitiva e das neurociências".

A evolução por seleção natural proposta por Darwin é um processo de caráter histórico que produz os sistemas biológicos, segundo Campos, Santos e Xavier (1997). Um organismo que desenvolva evolutivamente um "modelo interno do ambiente" torna-se mais adaptativo, situação semelhante ao que ocorre nos mecanismos cerebrais da atenção vinculados à seleção de possibilidades de ação. Tais sistemas possibilitam "executar ações presentes para favorecer ações futuras que sejam vantajosas" (CAMPOS, SANTOS, XAVIER, 1997, s/p). A historicidade é um elemento bastante enfatizado por Vigotski, não apenas no processo evolutivo ou de caráter filogenético mas principalmente no desenvolvimento cultural do indivíduo ou ontogenia - tais aspectos, obviamente, não podem desconsiderar-se mutuamente.

De acordo com Edelman e Tononi (2000, apud CESCON, 2009), há três grandes processos seletivos que definem o universo da consciência. No primeiro deles, o processo seletivo filogenético, a autoconsciência humana deriva de três fatores: biológico (aumento do volume cerebral, posição ereta, polegar opositor, conformação da laringe), cultural (capacidade crescente de interagir e manipular o ambiente) e social (crescimento do grupo onde vive). A este soma-se o processo seletivo ontogenético, relativo ao desenvolvimento individual de cada ser humano, num processo evolutivo relacionado com o ambiente, que “cria e reforça algumas estruturas cerebrais e enfraquece ou elimina outras. Sem estes estímulos e sem a resposta a tais estímulos, o nosso cérebro permaneceria uma mera "papa de neurônios" sem uma organização suficientemente complexa" (ibidem, p.17-18). Cecon (2009) conclui dizendo que "o desenvolvimento da consciência e da autoconsciência é o resultado de 
um percurso histórico individual, apesar de estreitamente conectado à genética" (p.18). Por fim, o terceiro processo, da seleção natural, é aquele onde ocorre uma "interação incessante com o ambiente que leva o nosso cérebro a distinguir o "si" do "não si", a pensar em si mesmo e a pensar no distinto de si, a pensar em si mesmo em relação aos outros, a imaginar, a criar" (ibidem, p.18). É interessante notar o papel fundamental que a interação com o ambiente exerce na formação do indivíduo e da consciência, indo de encontro ao que é proposto por Vigotski.

A consciência primitiva evoluiu com a capacidade de o córtex processar paralelamente um grande número de informações. Campos, Santos e Xavier (1997, s/p) conceituam aprendizagem como "o meio pelo qual a categorização ocorre, tendo por pano de fundo as mudanças adaptativas no comportamento que satisfazem às necessidades fisiológicas do indivíduo". As diferenças anatômicas entre o homem e os demais primatas parecem ter contribuído de forma decisiva para as características tipicamente humanas, ainda mais se tomadas em relação à grande similaridade genética entre eles, o que dificultaria explicar o abismo em termos de comportamento existente entre humanos e primatas. Os autores destacam que um argumento defendido pelo antropólogos é a contribuição do uso de instrumentos para o desenvolvimento da inteligência humana. Trata-se de um processo bidirecional, segundo eles: "é preciso inteligência para utilizar instrumentos, mas seu uso também contribui para o desenvolvimento da inteligência" (ibidem, s/p). Adiante, os autores concluem:

\footnotetext{
Inovações culturais mudaram as condições de expressão fenotípica de tal forma, e tão rápido, que teriam levado a diversas alterações comportamentais. Isso talvez permita avaliar por que a espécie humana possui maior heterogeneidade de comportamentos em relação a outras espécies. (ibidem, s/p).
}

Ou seja, nesta proposição está um dos pontos fundamentais do pensamento de Vigotski em relação ao papel dos instrumentos no desenvolvimento cultural humano. Os autores prosseguem atribuindo às inovações culturais a mudança expressiva das condições fenotípicas humanas e seu consequente resultado na mudança do comportamento, o que explicaria o grande repertório de comportamento humano face às demais espécies, destacando principalmente a linguagem como fator fundamental na evolução da espécie humana e o aumento na capacidade conceitual (CAMPOS, SANTOS, XAVIER, 1997, s/p). Este argumento é um dos principais defendidos por Vigotski. É surpreendente a sintonia entre a 
proposta vigotskiana e os argumentos neurocientíficos dos autores, como se pode notar no trecho a seguir:

\begin{abstract}
Palavras podem ser vistas como instrumentos para manipulação da informação. O armazenamento, de longa duração, de relações simbólicas, adquiridas através de interações com outros indivíduos da mesma espécie, libera o indivíduo do presente imediato. A eficácia desse processo está na possibilidade de interpretar itens como símbolos de forma abstrata e bem definida, de acordo com um grupo inequívoco de regras (sintaxe - manipulação de símbolos através de um procedimento definido). A partir deste substrato, desenvolveram-se capacidades semânticas, representadas pelo processo funcional de manipulação dos símbolos. Para alguns autores, esta última etapa corresponderia ao florescimento da consciência "superior", vista aqui como a capacidade de refletir sobre as próprias experiências ao longo do tempo, como ocorre em seres humanos (e.g., Farthing, 1992). Assim, como linguagem é adquirida pela interação com outros indivíduos da espécie, depreende-se que a consciência decorre também de um processo social (ibidem, s/p).
\end{abstract}

Mais à frente, observa-se outro ponto de encontro entre Vigotski e neurocientistas, no que se refere à contextualização ambiental do desenvolvimento humano em contraposição ao que é inato ou herdado:

Deve-se enfatizar que embora fatores genéticos determinem, em certa extensão (ver abaixo), sequências de desenvolvimento embrionário, bem como parte da especificação dos padrões de conectividade neuronal, isso não exclui a contribuição decisiva e marcante da interação do indivíduo com o ambiente, incluindo a história de desenvolvimento individual associada às influências culturais, para a formação final do sistema nervoso (ibidem, s/p).

Citando experimentos com gêmeos univitelinos em que um deles apresenta esquizofrenia, Campos, Santos e Xavier (1997) observam que ocorrem diferenças anatômicas entre eles devido a fatores não conhecidos, mesmo que sua herança genética seja igual, e uma explicação possível estaria nas diferentes experiências vivenciadas pelos irmãos durante seu desenvolvimento, o que enfatiza a plasticidade do sistema nervoso. Novamente, reforça-se aqui o argumento vigotskiano de que o desenvolvimento cultural é o grande fator característico do humano, onde a ontogênese não recapitula a filogênese. Observe-se o que argumentam os autores:

Do ponto de vista teórico é praticamente impossível que dois organismos sejam expostos exatamente às mesmas sequências de eventos e estímulos do ambiente, pelo simples fato de ocuparem posições diferentes do espaço. Suas histórias de interação com o ambiente serão diferentes, o que resultará em sistemas nervosos diferentes, ainda que os patrimônios genéticos sejam os mesmos. Esses fatores, críticos para o processo de adaptação ao ambiente, conferem individualidade cognitiva e afetiva (ibidem, $\mathrm{s} / \mathrm{p}$ ). 
Campos, Santos e Xavier (1997) defendem que a individualidade pode ser entendida sob uma perspectiva biológica, e que isso enfraquece a ideia de que os valores humanos estariam em contradição com a concepção da mente humana enquanto fenômeno biológico.

Por ser único no seu patrimônio genético e particularmente no seu patrimônio histórico, cada indivíduo é singular na sua essência e criatividade sendo, portanto, precioso. Exatamente essa singularidade de cada um é que deve ser respeitada e valorizada na condição humana (ibidem, s/p).

Para fechar essa discussão sobre a consciência de um ponto de vista neurocientífico e suas relações com a teoria de Vigotski, apresenta-se a seguir alguns apontamentos realizados por Luria em seu texto $O$ cérebro humano e a atividade consciente (publicado em 1992 pela editora Ícone, sem referência de data de publicação original, mas pelas obras citadas pode-se localizá-lo por volta de 1970). Luria desenvolveu uma extensa obra sobre o cérebro, desenvolvendo e consolidando a neuropsicologia proposta por Vigotski, contribuindo de forma fundamental com questões que permanecem atuais até os dias de hoje neste campo.

Neste trabalho, Luria aponta o aumento do interesse na pesquisa da relação entre cérebro e consciência por volta da metade do século XX, renascimento que atribui aos avanços da neurocirurgia e psicofarmacologia, às descobertas sobre o sono e vigília e ao desenvolvimento da tecnologia de microeletrodos. Com tudo isso, Luria avaliava na ocasião que o problema permanecia obscuro - como, aliás, continua até hoje. Para ele, o que estava atrasando a solução do problema da consciência decorria da abordagem teórica utilizada pelos cientistas que, segundo Luria, insistiam em compreender a consciência como qualidade subjetiva primária, experimentada diretamente, em relação à qual o mundo exterior ocupa uma posição secundária. Assim, a busca tem sido por aquilo que, no cérebro, corresponderia à experiência subjetiva da consciência. A crítica de Luria (197?/1992, p.192-193) era de que os pesquisadores não estavam encarando a questão da base cerebral da atividade consciente. Ao invés disso,

estão voltados não para a análise da qualidade histórica da consciência, o exame das formas básicas do reflexo consciente do mundo e a descrição de sua estrutura complexa e mutável, mas para a descoberta dos mecanismos da consciência no interior do cérebro, distinguindo as formações cerebrais ou as estruturas neuronais, por cuja estimulação as manifestações mais simples das experiências conscientes poderiam ser obtidas, ou por cuja destruição a qualidade da "experiência subjetiva" poderia ser removida do comportamento humano. 
Tal crítica baseia-se na visão de Luria (ibidem, p.194) de que a consciência não é uma espécie de estado primitivo da matéria viva, e nem os processos psicológicos surgiriam de alguma forma do interior das células, mas sim através

\begin{abstract}
das suas relações com o meio circundante, na fronteira entre o organismo e o mundo exterior, e ele assume formas de um reflexo ativo do mundo exterior que caracteriza toda atividade vital do organismo [...] os traços básicos desse reflexo, bem como suas formas básicas tais como foram estabelecidas no processo da história social devem ser procurados não no interior do sistema nervoso, mas nas relações concernentes à realidade, estabelecidas em estágios sucessivos de desenvolvimento histórico.
\end{abstract}

Portanto, a atividade psicológica em toda a sua particularidade estaria muito mais determinada pelas formas de existência que originam os diferentes sistemas funcionais que formam o comportamento, do que pelas propriedades internas dos neurônios. O que se reflete na consciência, para Luria, não são os processos internos das estruturas cerebrais, e sim o mundo exterior: "a consciência, como um reflexo da realidade objetiva, tem uma função biológica essencial, habilitando o organismo a encontrar seus propósitos, a analisar a informação que chega a ele e a armazenar seus traços" (ibidem, p.195-196).

É interessante confrontar essa opinião com a de outro eminente neurocientista da atualidade, António Damásio. Em 2000, Damásio lançou o livro O mistério da consciência, no qual aborda esta discussão fundamental e não solucionada da neurociência, propondo uma hipótese explicativa para a questão. Para ele, há dois problemas principais na questão da consciência, que estão intimamente relacionados. O primeiro busca responder como o cérebro transforma padrões neurais ou objetos em padrões mentais ou imagens. O segundo, que Damásio tenta responder no trabalho em pauta, é o que ele chama de problema do self, ou como a consciência torna-se um padrão mental unificado que reúne objeto e self, como parte do processo denominado mente (BISPO, 2003).

Damásio (2000) distingue três tipos de self que se articulam para a formação e manutenção da consciência, e se baseiam num funcionamento sistêmico do cérebro (este tipo de funcionamento, já proposto por Vigotski e corroborado por Luria, ainda permanece como paradigma dominante na neurociência atual). O proto-self tem um caráter biológico e inconsciente, e é responsável por mapear o estado do organismo para o cérebro. Sempre que acionado por um objeto ou padrão neural, o proto-self dá origem ao self central, que atua como protagonista transitório da consciência, representando aquilo que é consciente num 
momento específico, e como sempre há novos objetos sendo gerados, é produzida a sensação de continuidade. Por fim, Damásio acrescenta o self autobiográfico, aquele que se dá a partir da memória autobiográfica de um indivíduo, a partir de suas experiências, bem como os aspectos invariáveis da sua biografia. Para Damásio (ibidem, p.224),

\begin{abstract}
O verdadeiro prodígio, a meu ver, é a vinculação arquitetônica, nos aspectos neurais e cognitivos, da memória autobiográfica ao proto-self inconsciente e ao self central emergente e consciente de cada instante vivido. Essa conexão forma uma ponte entre o processo contínuo da consciência central, condenado como Sísifo à transitoriedade, e o conjunto progressivamente maior de memórias estabelecidas, sólidas como rocha, concernentes a fatos históricos únicos e a características consistentes de um indivíduo. Em outras palavras, a estabilidade do proto-self inconsciente, baseada no corpo e de alcance dinâmico, que se reconstrói a cada instante, ao vivo, e o self central consciente, que dela emerge no relato verbal de segunda ordem quando um objeto o modifica, são enriquecidos pela exibição associada de fatos memorizáveis e invariáveis - por exemplo, quando você nasceu, quem são seus pais, acontecimentos críticos em sua autobiografia, seus gostos e aversões, seu nome, etc. Embora a base para o self autobiográfico seja estável e invariável, sua abrangência muda continuamente em decorrência da experiência. A exibição do self autobiográfico é, assim, mais passível de remodelação do que o self central, que se reproduz de modo incessante, essencialmente da mesma forma, durante toda a vida.
\end{abstract}

Damásio dedica uma especial atenção ao self central: “embora o conteúdo do self autobiográfico pertença a um indivíduo de um modo absolutamente único, esse conteúdo depende do dom da consciência central para ganhar a vida, exatamente como qualquer outro a ser conhecido. Um tanto injusto, talvez, mas é assim que tem de ser" (ibidem, p.227). Damásio articula a este conceito o de consciência central (embora não deixe muito clara a diferença entre esta e o self central), definindo-o como o estado gerado para cada conteúdo do qual se está consciente, a partir da geração pulsante de novos padrões neurais. Assim, o foco da consciência, para Damásio, está nesta instância que se atualiza sob a influência dos padrões neurais do proto-self. Portanto, é um movimento de dentro para fora, ou de baixo para cima, ao contrário do que defende Luria, ou seja, que o reflexo da realidade gera a consciência.

Um outro ponto de discordância entre Damásio e a psicologia histórico-cultural é a importância atribuída à linguagem na formação da consciência. A narrativa da consciência, para Damásio, baseia-se em "um mapa não linguístico de eventos logicamente relacionados" (ibidem, p.238), como uma espécie de filme. Contudo, pontua que no caso específico dos seres humanos, "a narrativa não verbal de segunda ordem pode ser convertida em linguagem imediatamente" (ibidem, p.238), nomeando-a como de terceira ordem. O cérebro humano geraria de forma imediata uma versão verbal da história, o que para Damásio é uma possível 
explicação para a teoria de que a consciência é explicada apenas pela linguagem, com a qual discorda, defendendo que a linguagem faz parte do que chama de consciência de alto nível (ou autobiográfica): “o processo básico da consciência é incessantemente traduzido pela linguagem ou é, também se pode dizer, coberto por ela” (ibidem, p.145). Para Damásio, as palavras não vêm do nada, são precedidas por ações e eventos e traduzem conceitos: "quando a mente diz 'eu' ou 'mim' ela está traduzindo, com facilidade e sem esforço, o conceito não linguístico do organismo que é meu, ou do self que é meu” (ibidem, p.239). Para Vigotski e Luria, o movimento que ocorre é justamente o contrário. A linguagem não é uma tradução de conceitos inconscientes e não linguísticos em palavras, mas é a própria organização do pensamento e a consciência humana. Como aponta Luria (197?/1992), a comunicação (com a linguagem) leva ao desenvolvimento da fala, que por sua vez leva a uma reorganização radical da estrutura do processo psicológico como um todo, como por exemplo com novas formas de atenção voluntária e experiência emocional da realidade. Luria reitera a conclusão de Vigotski de que a consciência humana, em seus vários estágios de desenvolvimento, desde as primeiras experiências mais marcadamente emocionais até a aquisição do pensamento abstrato, difere tanto em sua estrutura semântica como por meio de diferentes sistemas psicológicos. Citando Vigotski, "as palavras, como elementos da fala, são correlativas da consciência, são as unidades básicas da consciência humana e não correlativas do pensamento" (ibidem, p.198).

Pode-se identificar, portanto, uma forma diversa se conceber a consciência por Vigotski e Damásio. Damásio preocupa-se com a narrativa não verbal e imagética, enquanto Vigotski com a narrativa verbal ou mais precisamente histórica da consciência. Damásio (2000) não aceita a hipótese de que a consciência central surgiria apenas no momento da tradução verbal e não antes, pois se assim fosse, segundo ele, a consciência dependeria da linguagem para existir. Argumenta que a mente linguística tende à ficção, fabricando narrativas que não "condizem com a verdade" (ibidem, p.241). A narrativa não verbal seria rápida e pouco explícita, uma vez que é encoberta pela linguagem, mas alguns de seus aspectos são captados no sentido do self e conhecimento, e precedem a tradução verbal correspondente. Nota-se, portanto, sua ênfase aos aspectos não linguísticos da consciência.

Damásio (ibidem, p.253) propõe ainda outro conceito, de consciência ampliada, que se baseia na central, mas é tipicamente humana. 
A consciência ampliada é a preciosa consequência de duas contribuições capacitadoras: primeiro, a capacidade de aprender e, com isso, guardar registros de uma infinidade de experiências, conhecidas previamente graças à consciência central; segundo, a capacidade de reativar esses registros de modo que, como objetos, eles também possam "gerar um sentido de self no ato de conhecer" e, assim, ser conhecidos.

Conceitualmente, a consciência ampliada de Damásio se aproxima mais da consciência semântica de Vigotski. Para Damásio (ibidem, p.257), a consciência central estaria sob forte influência do genoma, o que já não ocorreria com a consciência ampliada, onde a influência do meio é preponderante.

A consciência central é parte do equipamento-padrão de organismos complexos como o nosso; ela é estabelecida no início da vida pelo genoma, com uma pequena ajuda do meio. Talvez a cultura possa modificá-la em certa medida, mas provavelmente não muito. A consciência ampliada também é estabelecida pelo genoma, mas a cultura pode influenciar significativamente seu desenvolvimento em cada indivíduo.

O desenvolvimento da consciência autobiográfica, segundo Damásio (ibidem, p.293), não só depende do meio como muitas vezes é regulado por ele, como no caso dos diferentes padrões educacionais variando de acordo com a cultura e o meio social.

As regras e princípios de comportamento que governam as culturas em que um self autobiográfico está se desenvolvendo se encontram sob o controle do meio; o mesmo se pode dizer dos conhecimentos segundo os quais os indivíduos organizam sua autobiografia, que vão de modelos de comportamento individual aos fatos de uma cultura.

Damásio acrescenta um último conceito, o de consciência moral. Para ele, esta seria uma função verdadeiramente humana, envolvida com capacidades humanas como por exemplo "a percepção crítica de discordância que leva à busca pela verdade e o desejo de criar normas e ideais para o comportamento e para a análise dos fatos” (ibidem, p.295). Para Damásio, no entanto, o momento atual exige que o foco se volte para a consciência central, lançando como hipótese que o fato da consciência ampliada estar pouco explicada, e a consciência moral ainda menos, decorrem da consciência central ainda permanecer pouco esclarecida. Apresentando de forma resumida o encadeamento dos conceitos propostos por Damásio (ibidem, p.295) para o funcionamento da consciência, tem-se o seguinte:

a sinalização neural inconsciente de um organismo individual gera o proto-self que possibilita o self central e a consciência central, que por sua vez possibilitam o self autobiográfico, o qual possibilita a consciência ampliada. No final dessa cadeia, a consciência ampliada possibilita a consciência moral. 
Pode-se notar que o enfoque de Vigotski e Luria vai em outra direção. Luria (197?/1992, p.199) entendia que

as tentativas de se encontrar o substrato cerebral responsável pelos processos conscientes devem ser executadas não ao nível dos neurônios ou das moléculas, mas ao nível da analise da arquitetura dos principais sistemas cerebrais que constituem as unidades de aparelhagem ativa, que controla o comportamento como um todo

Para tanto, Luria defendia como método o estudo das mudanças de comportamento ocasionadas por lesões cerebrais locais ao invés da investigação anatômica ou da pesquisa eletrofisiológica. A análise e descrição cuidadosa de casos clínicos é marcante na obra de Luria, tendo inspirado outros neurologistas, como o inglês Oliver Sacks e mesmo Damásio, que na obra citada relata vários casos de forma detalhada para corroborar suas teses. Com isso, Luria não estava defendendo que a uma função psicológica estivesse relacionada uma área cerebral específica, e sim que "esta zona cerebral particular é importante para a atividade normal de todo o sistema funcional, e se esta parte do cérebro for destruída, o sistema funcional transforma-se plasticamente no sentido de superar a dificuldade e trabalhar diferentemente" (ibidem, p.202). Luria também observava que havia uma ligação estreita entre distúrbios da consciência e distúrbios da memória, tornando difícil delimitá-los na prática. A citação de Luria (ibidem, p.221-222) a seguir resume o enfoque histórico-cultural para a base neurológica da consciência:

Ao entender a consciência como uma forma complexa de recepção ativa da realidade, a psicologia moderna adota a posição, formulada algum tempo atrás por Vigotski, segundo a qual a consciência é semântica e localizada em sistemas funcionais estruturalmente definíveis, e, assim, passível de ser tratada por uma investigação verdadeiramente científica.

De acordo com esse ponto de vista, a consciência humana, que é o resultado de atividade complexa, e cuja função se relaciona com a mais alta forma de orientação no mundo circundante e com a regulamentação do comportamento, formou-se ao longo da história social do homem durante a qual a atividade manipuladora e a linguagem se desenvolveram, e seu mecanismo exige a intima participação destas. Ao refletir o mundo exterior, indiretamente, através da fala, a qual desempenha um papel profundo não apenas na codificação e decodificação das informações, como também na regulamentação de seu próprio comportamento, o homem é capaz de executar tanto a mais simples forma de reflexão da realidade como as mais altas formas de regulamentação de seu próprio comportamento. As impressões que chegam a ele, vindas do mundo exterior, são submetidas a uma complexa análise e recodificadas de acordo com categorias que ele aprendeu e adquiriu como resultado da complexa experiência histórica da humanidade, e sua ideia acerca do mundo exterior torna-se abstrata e generalizada, mudando com cada estágio do desenvolvimento psicológico. 
Uma última palavra sobre a questão da consciência deve ser dita em relação ao conceito de inconsciente. Para Vigotski, a consciência se vincula a um estado mental, o que não exclui a possibilidade do inconsciente. Para ele, o inconsciente é potencialmente consciente, sendo ambos aspectos do fenômeno psicológico. No entanto, Vigotski assinala que este entendimento é diverso do conceito psicanalítico de inconsciente, pois para Freud o inconsciente é algo real, que provoca ações (VIGOTSKI, 1930b/2004, p.156).

A questão do localizacionismo, ou localização das funções no cérebro, também merece destaque, uma vez que Vigotski dedicou textos específicos ao tema (VIGOTSKI, 1934/2004; VYGOTSKY, 1934/1977). A localização das funções no cérebro é um tema que tem mobilizado desde o começo a pesquisa neurocientífica, e já foi abordada aqui brevemente no que se refere à frenologia (conforme já abordado anteriormente). Ainda que hoje se reconheça que não há áreas especificamente destinadas a funções de forma determinista, e que pode haver diferentes localizações e compensações devido à plasticidade neuronal, não deixa de ser provocante pensar que as pesquisas a partir de imageamento cerebral são um tipo de frenologia pós-moderna ${ }^{52}$. Destacam-se estas questões aqui para indicar que ainda se trata de tema controverso, e se é assim na época atual, ainda era mais na época de Vigotski. O que foi pensado pelo psicólogo bielorrusso a esse respeito?

Vigotski entendeu que o cérebro se caracteriza fundamentalmente por um funcionamento sistêmico, ou seja, como um conjunto, e não como a mera soma de partes isoladas, cada uma respondendo por uma função. Nesse sentido, era contrário à abordagem frenológica e localizacionista.

Como apontado por Oliveira (2010), Vigotski concebia o cérebro como um sistema aberto em interação constante com o ambiente, transformando, como resultado desse processo, sua estrutura e funcionamento. Resulta desta concepção o pressuposto de Vigotski de que as funções psicológicas superiores são constituídas no decorrer da história social humana, mediada por instrumentos e símbolos em sua relação com o meio.

Em A consciência como problema da psicologia do comportamento (VIGOTSKI, 1925/2004), Vigotski refere que o sistema nervoso funciona como um conjunto, e que o

\footnotetext{
${ }^{52}$ Anotação de aula realizada durante a disciplina Neurociência Cognitiva: Percepção e Ação, do programa de pós-graduação em Neurociência da USP, no primeiro semestre de 2011, em discussão apresentada pelo Prof. Dr. Marcus Vinícius Chrysóstomo Baldo.
} 
cérebro teria a função de integração dos reflexos vindos de pontos distantes. Já em 1929, no Manuscrito, menciona que os processos neurológicos ocorrem pela articulação de funções cerebrais, e não dos centros nervosos isolados, esboçando o conceito de sistemas funcionais, que seria posteriormente desenvolvido por Luria.

Luria (1981, p.27) argumenta que os processos mentais são sistemas funcionais complexos que não estão localizados em áreas estritas do cérebro, mas ocorrem através da participação conjunta de estruturas cerebrais na composição destes sistemas. Distingue três unidades funcionais no cérebro, com uma estrutura interna hierarquizada, dispostas em três zonas corticais superpostas. São elas: 1) a unidade responsável pela regulação do tônus muscular ou a vigília, que ocorre nas áreas primárias ou de projeção; 2) a unidade responsável por obter, processar e armazenar informações vindas do exterior, que se dá nas áreas secundárias, de projeção-associação e 3) a unidade responsável por programar, regular e verificar a atividade mental, que ocorrem no córtex e são responsáveis, no ser humano, pelas formas mais complexas de atividade mental, cujo funcionamento depende de várias áreas corticais trabalhando em conjunto. Estas unidades funcionais agem em consonância na execução das ações do organismo, tendo uma maior ou menor participação em cada uma delas, e podendo variar seus mecanismos de ação de acordo com as exigências de cada tarefa.

É importante destacar aqui o significado que o termo função tem para Luria (1981), não relacionado com o funcionamento estrito de um grupo de células ou tecido em particular, mas sim com o funcionamento complexo de um dado conjunto de elementos orgânicos. Luria exemplifica o uso do termo com o que ocorre quando se refere à função da digestão, ou função da respiração: trata-se de uma ação sistêmica, que conta com a contribuição de várias instâncias do organismo. Desta forma, um sistema funcional não se caracteriza apenas pela complexidade de sua estrutura, mas também pela ação conjunta dos seus elementos. A tarefa desempenhada por tal sistema é constante e leva a um resultado constante, contudo, os mecanismos empregados para isso são variáveis, lançando mão dos diversos componentes de uma dada organização complexa.

Em Sobre a localização (VYGOTSKY, 1934/1977), Vigotski aponta que o traço característico do cérebro humano é a ausência de uma dependência do conjunto e a sua especialização em partes, com a qual ele generaliza a reflexão da realidade e da consciência. Defende a especificidade da localização das funções tipicamente humanas no cérebro. 
A teoria da estratificação de Kretschmer influenciou a tese vigotskiana, e posteriormente de Luria, acerca do desenvolvimento estrutural do cérebro. Essa teoria tem uma base anatômica, considerando que os sistemas neurais de suporte do organismo, como o tálamo, são mais antigos do ponto de vista filogenético, da mesma forma que o córtex seria a camada mais recente. Em História do desenvolvimento das funções psíquicas superiores (VYGOTSKI, 1931/2000), Vigotski fala sobre o desenvolvimento estratificado do cérebro, utilizando o conceito como apoio para a opção metodológica de estudar a conduta humana em sua estrutura geológica, ou seja, o contexto genético da história da conduta. É interessante destacar esse ponto, pois indica a forte influência dos estudos neurofisiológicos, históricos e evolucionistas na obra de Vigotski.

No texto A psicologia e a teoria da localização das funções psíquicas (VIGOTSKI, 1934/2004), trabalho que merece destaque por tratar detalhadamente da questão do funcionamento cerebral, Vigotski aponta algumas conclusões que merecem ser comentadas com mais detalhamento.

Inicialmente, Vigotski defende que a atividade cerebral ocorre em função da atuação conjunta e não homogênea das partes envolvidas. Essa atividade é integrada a partir de relações dinâmicas e organizadas hierarquicamente. O desenvolvimento das funções psicológicas superiores introduz uma nova forma de funcionamento na organização do cérebro e em seu funcionamento conjunto, onde se destaca a maneira de funcionar, ou a relação entre as partes, mais do que a atuação destas partes. A correlação entre as unidades funcionais e estruturais do cérebro é particularmente identificável no caso das deficiências e lesões, o que decorre do caráter histórico do desenvolvimento das funções psicológicas superiores a partir das funções psicológicas inferiores ou elementares.

A questão da atuação funcional para Vigotski é análoga ao funcionamento modular atualmente aceito pela neurologia, como pode ser visto em Xavier (1993, p.108, apud CAMPOS, SANTOS, XAVIER, 1997). Segundo este autor,

cada módulo mantém conexões diferentes com os outros e o nível de independência no funcionamento desses módulos parece variar. Lesões em módulos independentes eliminam as funções por ele desempenhadas, enquanto lesões em módulos que cooperam resultam numa alteração de desempenho dos módulos remanescentes de modo a minimizar as deficiências. $\mathrm{O}$ funcionamento independente, porém cooperativo, entre os diferentes módulos permite explicar não só dissociações experimentais observadas em indivíduos com lesões cerebrais, mas também a sensação de uma experiência de memória única em indivíduos normais. 
Outra conclusão importante de Vigotski diz respeito às conexões extra-cerebrais. O ser humano caracteriza-se pelo estabelecimento de conexões extra-cerebrais em seu processo de desenvolvimento, conexões estas constituídas através da atividade externa e social, e que posteriormente são interiorizadas e transformadas/convertidas em atividade interna. Essa característica possibilita que funções lesadas ou subdesenvolvidas possam ser compensadas com seu deslocamento para fora, a partir de recursos externos. O exemplo clássico de conexão extra-cerebral são os recursos utilizados como compensação por pessoas com deficiência - por exemplo, a utilização do sistema Braille por uma pessoa cega a fim de acessar o conteúdo de uma determinada obra literária.

Este conceito é particularmente importante porque aponta a importância do contexto social em que uma pessoa se desenvolve no sentido de influenciar o tipo de desenvolvimento cerebral que poderá alcançar através da interação com os elementos proporcionados por este meio. Com isso, no entanto, não se está propondo que a relação entre indivíduo e meio esteja condenada a não ultrapassar um determinado limiar de desenvolvimento, como colocado no conceito de período crítico. A ideia de que há determinados períodos críticos ou janelas de desenvolvimento já foi bastante dominante na neurociência, quando se acreditava que o número máximo de neurônios estaria fixado já no nascimento, pois, ao contrário de outras células, os neurônios não se regenerariam durante a vida, sinalizando os danos que ocorreriam por uma degeneração progressiva no processo de envelhecimento ou por acidentes que lesionassem o sistema neurológico. Segundo essa noção, haveria um período específico de desenvolvimento ótimo, após o qual o desenvolvimento estaria dificultado ou até mesmo impedido, chamado de período crítico. Por exemplo, a ideia de que tudo o que é crucial no desenvolvimento neurológico ocorre até os três anos de idade, devendo as intervenções educativas focar-se nesta fase, após o que teriam pouca possibilidade de mudar os rumos do desenvolvimento neurológico.

Esse tipo de colocação se apoia em pesquisas como as desenvolvidas na década de 1970 por Lorenz (OCDE, 2007), na qual observou que filhotes de pássaros ao nascer ficavam permanentemente ligados ao primeiro objeto móvel que se destaca no ambiente (geralmente a mãe), fenômeno que chamou de "imprinting", ou ainda as pesquisas desenvolvidas com privação visual em gatos por Hubel e Weisel a partir de 1950, quando demonstraram a plasticidade do sistema visual através da influência do meio na especialização do córtex visual e a sua reversibilidade decrescente com a idade do animal, até atingir a irreversibilidade 
(LENT, 2004). No entanto, se a definição de período crítico é adequada para as situações em que um evento ou a sua ausência ocasiona uma situação irreversível, não se pode extrapolar essa definição para a aprendizagem humana, pois não há nenhuma comprovação científica de que isso ocorra (OCDE, 2007). Pelo contrário: as pesquisas têm demonstrado que a plasticidade neuronal ocorre até em idades mais avançadas, e que a aprendizagem pode ocorrer além de períodos determinados, com o que se torna mais correto falar em períodos sensíveis ao invés de períodos críticos no caso do desenvolvimento humano, ou seja, períodos nos quais a aprendizagem seria facilitada, como ocorre por exemplo na aprendizagem de uma língua estrangeira ou mesmo da linguagem (OCDE, 2007). Além disso, a partir da década de 1990, começaram a surgir evidências científicas de que a neurogênese, ou nascimento de novos neurônios, ocorre durante toda a vida. O caráter plástico do sistema nervoso é dotado de grande capacidade de adaptação e superação. Isso pode ser observado nas extraordinárias histórias de recuperação a partir de lesões cerebrais importantes a partir da terapêutica correta, intervenção precoce, medicamentos e terapias de apoio - ou seja, dos melhores recursos de reabilitação disponíveis, e também em pesquisas com desenvolvimento cerebral em adultos. Pode-se citar como exemplo uma pesquisa publicada recentemente no prestigiado periódico Nature (CARREIRAS et al., 2009) realizada com indivíduos que se alfabetizaram na idade adulta e apresentaram modificações em áreas cerebrais passíveis de serem relacionadas com o aprendizado da leitura e escrita, em comparação com indivíduos da mesma faixa etária não alfabetizados. Portanto, o ditado popular de que sempre é tempo de aprender encontra hoje respaldo científico. Desta forma, oferecer possibilidades para o desenvolvimento humano e para a aprendizagem, seja em que época for, é uma maneira de propiciar o estabelecimento de conexões extra-cerebrais, fundamentais para o desenvolvimento humano, uma vez que colaboram para a remoção de barreiras entre o indivíduo e sua cultura.

Garai (1996) assinala que os processos mentais superiores podem ser tratados ao mesmo tempo tanto como produto do funcionamento de estruturas cerebrais, de caráter intraindividual, quanto de estruturas de significado, cujo caráter é interindividual. Reiterando a proposta vigotskiana, argumenta que a pesquisa sobre as funções cerebrais superiores deve ser tomada como tão importante quanto a pesquisa sobre as funções elementares, defendendo a introdução do conceito de significado na pesquisa sobre o cérebro. $\mathrm{O}$ autor ressalta que, na pesquisa psicológica, o sistema básico de observação científica foi definido ao nível do organismo individual, enquanto que, para a biologia, este foi apenas um nível transposto e 
substituído pela descrição no nível celular e em seguida molecular, convivendo com uma biologia da população, num nível muito mais amplo. Esta característica da psicologia deve-se à sua herança filosófica, que combinada a seu projeto de emancipar-se da filosofia aliou-se à biologia na descrição do comportamento observável, o que resulta numa ideia de consciência como tendo um substrato orgânico.

Para Garai (1996), no entanto, permanece a questão de explicar o significado enquanto fenômeno mental interindividual, ou de como transcendem o organismo individual. Nesse sentido, o conceito de sistema funcional de Anokhin baseia-se exclusivamente no organismo, e as estruturas ambientais são tomadas apenas como fontes de aferência e reaferência. Já a teoria da atividade de Leontiev e outros transcende este modelo, segundo Garai (1996), na medida em que conceitua a função de um órgão não apenas restrita ao sistema nervoso central, mas incluindo as estruturas nervosas, somáticas, e vegetativas do corpo individual. Isso também já foi proposto por Vigotski e reafirmado por Luria no conceito de sistema funcional. A constituição psíquica do indivíduo ocorre na medida em que esse desenvolve sua atividade orientada aos objetos, atividade essa organizada por suas ferramentas que, como sinais, são produtos históricos de uma cultura. Desta forma, nesta concepção a mente humana é tanto um produto do funcionamento do cérebro individual quanto das estruturas culturais interindividuais.

Se essa teoria explica o funcionamento tanto de estruturas internas quanto de estruturas externas, Garai (1996) conclui que ela se fundamenta em uma mesma superestrutura composta de ambos os tipos de estruturas, ou seja, aquelas dentro de um organismo individual e aquelas fora dele, em seu ambiente. Já que a função de organizar seu órgão é uma atividade orientada a objetos, a estrutura produzida por esta atividade transcende o organismo individual, incluindo seu ambiente. Tal ideia foi discutida por Vigotski no seu conceito de conexões extra-cerebrais, ou seja, os elementos culturais incorporados pelo indivíduo e que passam a integrar seu funcionamento mental superior, como no caso dos recursos compensatórios utilizados por pessoas com deficiências sensoriais (Braille, linguagem de sinais, etc). Garai (1996) argumenta nesse sentido citando a perspectiva ecológica em psicologia, que coloca como unidade de análise o organismo em seu ambiente. A teoria da percepção direta formulada por Gibson pressupõe que o contexto ou envolvimento contenha toda a informação necessária para o indivíduo que, por sua vez, é capaz de extrair essa informação e atuar no meio, num processo não mediado e baseado na premissa da 
mutualidade, ou seja, da sinergia entre indivíduo e meio, que formam uma realidade única de mútuo constrangimento, o que constitui o ecossistema, e baseia a teoria dos sistemas dinâmicos, segundo Gibson (apud FRANCO, 2000). O indivíduo comporta-se, portanto, em função do que a percepção lhe permite (afford), daí o termo criado por Gibson de affordance (aqui traduzido livremente como possibilidade), conceito complementar ao de efetividade (effectivity). Para Turvey, Fitch e Tuller (1982, apud FRANCO, 2000), a aprendizagem é o controle dos graus de liberdade do indivíduo em face desse contexto. A proposição de Gibson em favor de uma concepção ecológica da percepção, segundo a qual "a possibilidade [affordance] de algo é uma combinação específica das propriedades da sua substância e superfície tomadas em referência a um animal" é completada pela definição de Turvey e Shaw de que "a efetividade [effectivity] de qualquer ser vivo é uma combinação específica das funções de seus tecidos e órgãos tomados em referência a um ambiente", o que completam assinalando que "um ambiente é definido como um conjunto de possibilidades ou uma estrutura de possibilidades, e um animal é definido como um conjunto de efetividades ou uma estrutura de efetividades" (apud GARAI, 1996).

Acrescentando os conhecimentos acumulados pelos estudos etológicos acerca da ocupação territorial por grupos às teorias da atividade objetal e da mutualidade na ação entre indivíduo e ambiente, Garai (1996) lança algumas hipóteses sobre o que seria o órgão para lidar com significados. No entanto, o autor assinala que esta não é uma síntese teórica fácil, já que o comportamento territorial - como é concebido pela etologia - não tem a ver com a abordagem histórico-cultural, bem como com a teoria da atividade, assim como a teoria da estrutura ecológica da percepção não tem uma dimensão histórico-social. Ainda assim, o autor se arrisca a fazê-la, pois considera a dimensão histórico-cultural dos significados tão essencial quanto sua dimensão sócio-territorial. Garai (1996) assinala que a necessidade de considerar o aspecto social do significado foi indicada por Vigotski, que o considerava não apenas como em sua dimensão intraindividual ou da generalização mas também como em sua dimensão interindividual ou da comunicação. Como já apontado, segundo Vigotski a dimensão intraindividual é constituída a partir da dimensão interindividual, portanto a generalização tem uma origem psicossocial. No entanto, Garai (ibidem, s/p) dirige sua análise para a dimensão interindividual ou social, argumentando que as descobertas recentes têm convergido na direção de apoiar a suposição de que os valores semânticos na ontogênese da consciência humana são provenientes de categorização social. 
A categorização social precoce não ocorre como um ato consciente de pensamento: ela é mediada por um processo inconsciente de semiose no qual manifestações difusas como a vocal, motora, postural, vaso-motora ou outras manifestações somáticas da criança tomam forma de significantes que estão ligados paralelamente a categorias socialmente formadas como seus fatores significativos, portanto estes fatores semelhantes devem ser simbolizados por outros semelhantes, e os fatores diferentes por diferentes significados.

Assim, Garai (1996) argumenta que os indivíduos são tratados em relação a sua estrutura social, indo além do organismo individual. Determinadas estruturas são relacionadas a certos indivíduos, configurando um tipo de comportamento territorial, com referência ao qual a criança identifica-se com alguns indivíduos ao mesmo tempo em que os categoriza, diferenciando-os. Estas categorias sociais e as operações mentais que a criança realiza com elas dão origem ao aparato lógico que permite que a criança opere com os objetos internalizados da mesma forma com que fez inicialmente com os objetos do espaço externo, estruturando assim o espaço interno como fez com o externo, e desta forma operando com os significados dos objetos. Garai (ibidem, s/p) postula que "quanto mais orgânico é um papel desempenhado por um atributo de um objeto em atos de categorização social, mais cedo a criança irá aprender a lidar logicamente com seus atributos". O autor adverte ainda que este tipo de relação, ao contrário de um engano comum no pensamento psicológico, não pode ser reduzido aos processos da consciência individual ou aos produtos armazenados na memória individual. Garai (1996) refere que é possível aceitar a questão de Popper, acerca de uma estrutura psíquica supra-individual, sem no entanto aceitar sua resposta a ela, assumindo que significados estão ligados à formação de categorias e identidades sociais, bem como que o psiquismo baseia-se em uma superestrutura extra-psíquica que transcende o organismo individual, elevando-se a partir do organismo para uma estrutura que incorpore também fatores ambientais, e do indivíduo para uma formação supraindividual. Na medida em que estes dois pressupostos estão colocados, segundo o autor, pode-se derivar estruturas e operações lógicas a partir de estruturas e operações sociais reais dentro de uma organização que transcende o organismo individual.

Garai (1996) adverte ainda que o caráter interindividual dessas estruturas e operações não pode ser reduzido àqueles referidos em textos de Vigotski sobre a ZDP, justificando que tais estruturas não se estabelecem apenas com pessoas com conhecimentos supostamente mais avançados do que os da criança, mas entre crianças também, o que nos parece uma interpretação equivocada do conceito vigotskiano, que não se limita a adultos na 
interação típica da ZDP. No entanto, como o próprio Garai (1996) afirma, as contradições são a motivação essencial do desenvolvimento de um sistema, de acordo com a teoria de Vigotski.

Outra contribuição interessante ao debate sobre as possíveis relações entre neurociência e educação com a psicologia histórico-cultural é a discussão feita por Wolfe (2011), historiador da ciência. O autor refere que as ciências da cognição, especialmente na década de 1950, com os estudos sobre inteligência artificial, eram vistas com desconfiança e até aversão por pensadores marxistas e outros, por relegarem a dimensão simbólica do humano a um plano secundário. Dessa época até hoje, a discussão sobre a cognição social tem se ampliado, modificando o caráter individualista que as ciências cognitivas aparentemente assumiriam, com o fortalecimento do debate sobre temas como empatia, imitação, "leitura da mente" e cognição grupal, o que reitera a concepção da mente como fundamentalmente social, conforme destacado por Wolfe (2011).

Wolfe (2011) delimita sua discussão em torno do que conceitua como "o cérebro espinosano" ou, como formulado pelo filósofo socialista Aaron Zalkind, "o córtex socialista". Pensar o cérebro como algo social é um exercício realizado por Espinosa e também por Marx (que utilizou a expressão "cérebro social"), Vigotski e mais modernamente pelo filósofo marxista italiano Antonio Negri, como destaca Wolfe (2011). Dessa forma, Wolfe (2011) faz uma provocação aos críticos da ciência cognitiva motivados politicamente em sua argumentação de que tais pesquisas possuem necessariamente um caráter individualista e “reacionário". Com isso, o autor não está defendendo que todos os conceitos de cérebro social sejam iguais. Em "epistemologia social", o "social” refere-se aos estados de espírito coletivos, enquanto na "cognição social", o "social" assinala temas como neurônios espelho, ou seja, os neurônios especializados na decodificação das ações pela observação de indivíduos com habilidades biológicas assemelhadas, portanto, envolvidos na aprendizagem por imitação e na atribuição de estados mentais a outras pessoas (a questão da imitação, aliás, foi bastante enfatizada por Vigotski em seu conceito de Zona de Desenvolvimento Proximal).

A abordagem ecológica e etológica no estudo do cérebro, proposta por Gibson e reiterada por filósofos como Clark e Chalmers, com um olhar para a relação entre indivíduo e ambiente, tem dominado o pensamento neste campo, mas Wolfe (2011) ressalta que se trata de um ambiente concebido em termos de estímulo e resposta, e não um ambiente cultural, histórico e social. Assim, o autor não pretende enfrentar essa discussão, mas enfocar 
justamente o conceito de cérebro social "como emergiu da metafísica pós-cartesiama de Espinosa para as represálias neurológicas e marxistas em Vigotski e Negri” (ibidem, p.367).

Wolfe (2011) aponta que, para Espinosa, o indivíduo é uma intersecção particular em um mundo de relações, ou um modo finito da substância infinita, onde as intersecções, sejam humanos, animais ou objetos, se esforçam para continuar a existir e tendem a se preservar, o que foi conceituado como conatus pelo filósofo holandês. Um indivíduo, ou agente, portanto, é um determinado quantum de esforço, e não é definido por sua interioridade, pois estaria privado a princípio de estados mentais. Portanto, "as paixões não são propriedade de uma natureza humana essencial, ou de um indivíduo isolado, mas sim de um espectro relacional entre uma pluralidade de indivíduos. Em vez do cogito ergo sum de Descartes, Espinosa diz homo cogitat (Ética II, axioma 2): não há um self primordial, mas sempre um processo - uma rede" (ibidem, p.368).

Conforme assinala Wolfe (2011), a crítica monista de Luria à psicologia é espinosana, apontando que a psicologia era muito dualista, pendendo ora para o mecanicismo, ora para o vitalismo. Vigotski sugeriu que a psicologia deveria passar por uma reforma espinosana, em que o pensamento é uma função do cérebro e não há uma vida mental existindo de forma independente. Como disse Vigotski, "para Espinosa, o pensamento não é uma substância, mas um atributo. Os fenômenos mentais não existem por si, mas são um momento necessário em um complexo processo psicofísico" (ibidem, p.368). Em outro texto citado por Wolfe (2011), Vigotski afirma que Espinosa foi um determinista, concebendo o homem como capaz de controlar seus afetos através de seu intelecto, utilizando-se disso como argumento para defender a exatidão da primazia dos afetos postulada pelo filósofo holandês, pois na ontogênese as emoções humanas estão conectadas tanto com a autoconsciência quanto com o conhecimento da realidade do indivíduo. Wolfe (2011) completa sua argumentação com o conceito espinosano de "noções comuns", segundo o qual há concepções compartilhadas por todas as pessoas (por seus corpos/cérebros), e quanto maior é o conhecimento material do corpo, mais a mente é capaz de perceber as coisas adequadamente, possibilitando que o indivíduo não se perceba como singular e sim como parte de uma grande máquina-rede, o que justifica serem os afetos sociais, fundamentados nesta alteridade.

Após essa retomada dos conceitos espinosanos, Wolfe (2011) assinala que quem primeiro apontou o caráter social do cérebro, refletindo anatomicamente as influências linguísticas, sociais e culturais foi Vigotski, seguido por Luria, nas décadas de 1920-1930. A 
atividade linguística foi bastante estudada por Vigotski, que a entendia como intersubjetiva, defendendo um ponto de vista contrário ao de Piaget, ou seja, o processo de socialização passa do social para o individual, e não de uma perspectiva autista para uma socializada, como defendeu o epistemólogo suíço, além do que Vigotski enfatiza a pluralidade dos contextos de desenvolvimento, ao contrário de Piaget, que procurou leis universais do desenvolvimento. O indivíduo é social, e o sistema nervoso central carrega evidências dessa interação social inicial. Pela plasticidade, as experiências são incorporadas nas modificações sinápticas, como sublinha Wolfe (2011). Como Vigotski apontou, as funções psicológicas superiores emergem da interação dialética entre biologia e cultura, numa história específica de desenvolvimento. Luria completou dizendo que o desenvolvimento de órgãos funcionais, ou seja, que se estendem além do corpo/cérebro, ocorre pela formação de novos sistemas funcionais, e torna-se um meio para o desenvolvimento ilimitado da capacidade cerebral, justificando a conceituação do cérebro como o "órgão da civilização". A esse respeito, observe-se a pesquisa publicada recentemente sobre os efeitos do crescimento da Internet e do onipresente programa de buscas Google na memória - basicamente, os pesquisadores discutem a hipótese de que a facilidade de acessar as mais diversas informações a qualquer momento fez com que as pessoas tivessem uma queda na capacidade de recuperar informações memorizadas. Conforme apontam, “a Internet tornou-se uma forma primária de memória externa ou transacional, onde a informação é armazenada coletivamente fora de nós mesmos" (SPARROW; LIU; WEGNER, 2011). De fato, é um bom exemplo para o que Vigotski e Luria conceituaram como as ilimitadas possibilidades das conexões extra-cerebrais - de uma forma, provavelmente, que ambos jamais imaginariam, uma vez que a coletividade envolvida é virtualmente formada pelos habitantes de todo o planeta.

Wolfe (2011) recupera o conceito de "córtex socialista" proposto por Aaron Zalkind, que, assim como Vigotski, entendia o córtex e o socialismo como compartilhando um mesmo caminho - o psicólogo bielorusso declarou que "a história, ao mudar o tipo humano, depende do córtex; o novo homem socialista será criado através do córtex; a educação é, em geral, uma influência sobre o córtex" (apud WOLFE, 2011, p.370). Segundo Wolfe (ibidem, p.370), Vigotski “procurou colocar 'carne' cerebral sobre o 'esqueleto' ontológico marxista" defendendo que o humano é definido substancialmente pelo conjunto de relações sociais a que pertence, acrescentando uma base mais naturalista aos pressupostos de Marx no que se refere ao desenvolvimento da mente - contudo, é importante ressaltar que 
sem essa fundamentação filosófica marxista o conceito de "córtex socialista" se esvazia. Wolfe (2011) especula que, ao invés de chamar o córtex de órgão do socialismo, poder-se-ia apontar para a manisfestação na arquitetura cortical da vida cultural, simbólica e linguística. Como sugere Deacon, sobre nossa "espécie simbólica", os símbolos desempenham um papel fundamental na formação de nossas características cognitivas, o cérebro e a linguagem coevoluem, e o cérebro, em sua peculiaridade dinâmica de funcionamento, reflete essas características, que mostram sua integração ao mundo social. Wolfe (ibidem, p.370) faz uma ressalva importante ao destacar que, embora a maior parte das pessoas não perceba, ao se referir a esta dinâmica auto-transformadora, Vigotski e Luria estão falando do cérebro como um órgão propriamente dito - afinal, ambos eram materialistas, e entendiam o cérebro "não apenas como mais um ‘órgão' de mediação entre mente e sociedade através da linguagem, e não apenas uma 'abstração físiológica', como diria Feuerbach".

A noção de cérebro social aparece nos Grundrisse de Marx, no que ele chama de "forças produtivas gerais do cérebro social", relacionando-o ao processo de automação. Aponta que a natureza não constrói máquinas e sim a indústria humana, transformando-a em órgãos da vontade humana sobre a natureza, órgãos do cérebro humano, criados pela mão humana e objetivados (MARX apud WOLFE, 2011). Assim, o agente de transformação e operador real é o cérebro social, que tornou-se uma força produtiva em si mesmo, agente que reside tanto nos humanos quanto nas máquinas inteligentes. De acordo com Negri (2002, apud CÂNDIDO, 2011), o capital fixo, aquele que determina a produtividade, é o próprio cérebro do trabalhador, sua máquina-ferramenta, sendo este o maior diferencial das relações produtivas atuais.

O cérebro espinosano ou o cérebro social, para Wolfe (2011), não pode ser abstraído desse universo de relações, nem deve ser confundido com uma perspectiva fenomenológica do tipo "o homem pensa, e não o cérebro", com a ideia computacional da inteligência artificial (já que o cérebro social é material e dirigido ao outro) e nem, por fim, com a distinção tradicional entre ciências naturais e ciências humanas, pois não faz distinção entre um mundo material e outro espiritual. Citando Negri, Wolfe (2011) afirma que o potencial de um agente é inseparável do seu "conjunto de próteses", ou seja, os possíveis conjuntos de andaimes, redes e extensões tecnológicas da nossa percepção, cognição e ação: “A ferramenta [...] mudou completamente. Já não precisamos de ferramentas para transformar a natureza [...] ou para estabelecer uma relação com o mundo histórico [...], nós só precisamos 
de linguagem. A língua é a ferramenta. Melhor ainda, o cérebro é a ferramenta, na medida em que é comum” (NEGRI, apud WOLFE, 2011, p.372). "Conjunto de próteses”, como entendido aqui, é um conceito semelhante ao vigotskiano "conexões extra-cerebrais" anteriormente apresentado e discutido. O cérebro é "comum" por ser constituído de forma inseparável da rede de relações a que pertencemos, e o que há de concordância nos conceitos de "noção comum" de Espinosa, "intelecto geral" de Marx e "córtex socialista" de Vigotski é essa vulgarização, como Wolfe (2011) designa, em oposição à ideia clássica de pensamento como uma atividade contemplativa e solitária - e justamente por isso não há sentido em separar cérebro e ferramenta.

Wolfe (2011) conclui aventando algumas implicações possíveis dessa discussão. Reflete que não há uma separação entre um agente individual e seu cérebro da rede de afetos e objetos ao seu redor. Acrescenta que a individualização decorre do poder, tanto no sentido vigotskiano do indivíduo ser um produto da socialização e não o contrário, quanto no espinosano, de quanto mais extensões um indivíduo tiver, maior será seu poder de ação - de um nó no lenço passando pelo acesso à Internet e indo além. Conclui dizendo que o conceito de cérebro social que apresenta não é redutível a uma manifestação individual do mundo social, mas sim o contrário, uma vez que a arquitetura cerebral reflete as formas de organização social, cultural e linguística. Assim sendo, o grupo tem uma "mente grupal"? Esta não é uma implicação da discussão feita por Wolfe (2011), segundo ele, que objetivou com isso demonstrar que o cérebro pode ser pensado em uma dimensão sócio-política mantendo, ao mesmo tempo, suas características específicas de desenvolvimento, numa perspectiva genuinamente materialista.

Para concluir, apresentam-se aqui algumas questões levantadas por Coelho (2006) assim como algumas respostas possíveis a elas em face dos pressupostos da psicologia histórico-cultural. A autora assinala a questão da relação entre as funções psíquicas superiores e a atividade cerebral, perguntando-se se estariam tais fenômenos submetidos a processos similares aos da sensibilidade e dos atos reflexos, ou se difeririam desses devido a sua forma peculiar de gênese e construção. Coloca também a questão do binding problem, ou seja, como os processos psíquicos são integrados, ou como a consciência é construída a partir dos diversos processos neurais que ocorrem no cérebro. Por fim, Coelho (2006) também questiona a ocorrência de modalidades diferenciadas de integração psíquica em diferentes indivíduos ou 
grupos culturais, conjecturando se tais diferenças se deveriam a questões anatômicas e/ou bioquímicas do cérebro, ou se seriam expressões da personalidade desses indivíduos.

Coelho (2006) busca respostas a esses questionamentos de uma perspectiva histórico-cultural discutindo o modelo sistêmico social, que pressupõe uma correlação existente entre o cérebro e a dinâmica psíquica. Em tal modelo, as funções cerebrais são consideradas cronogenéticas, ou seja, decorrentes de novas correlações funcionais que ocorrem no processo de desenvolvimento ontogenético, o que resulta em interconexões peculiares entre diferentes regiões do cérebro. Tal processo baseia-se em uma reestruturação sistêmica que ocorre constantemente durante o processo de desenvolvimento em função da complexidade crescente do ambiente. Essas novas formações estariam implicadas com as condições peculiares do desenvolvimento humano, derivando num cérebro com princípios de organização e localização tipicamente humano, no sentido social, cultural e histórico desse desenvolvimento. Coelho (2006) assinala que os autores que defendem a perspectiva sistêmica social entendem que o desenvolvimento do cérebro humano é diretamente influenciado pelas condições ecológicas, resultando numa formação complexa capaz de analisar e sintetizar com precisão as informações do ambiente, e orientando-se em razão das alterações tanto desse ambiente quanto - e principalmente -, em relação às alterações provocadas pelo homem no ambiente, portanto ao ambiente alterado pelo homem. No ser humano, portanto, conforme aponta Coelho (2006, p.148),

\begin{abstract}
a intencionalidade dos atos individuais ultrapassa aqueles de ordem mais genérica da conduta instintiva, criando novas conexões neurônicas, sendo estimulado e retroagindo sobre os impulsos primários relacionados à sobrevivência do organismo e da espécie. O processo dialético entre as mutações genéticas e a seleção ocorre em função das condições coletivas de existência.
\end{abstract}

Em relação ao que seria o modelo sistêmico social de Vigotski e Luria, segundo Coelho (2006), as proposições principais seriam a existência de relações interfuncionais modificáveis no processo de desenvolvimento humano, em que a articulação de funções elementares resulta em sistemas funcionais dinâmicos. Assim, as funções psíquicas não procedem da atuação isolada de centros cerebrais, conforme a visão localizacionista estrita, bem como o cérebro não funciona como uma massa indivisível, e sim como um sistema interativo. Coelho (2006) enfatiza ainda o papel fundamental que a linguagem ocupa para Vigotski e Luria, com sua conversão do meio externo para o interno, processo em que se tornando a principal base de regulação da conduta humana e atua na formação de novos 
sistemas funcionais, através dos signos enquanto instrumentos de comunicação entre o ser humano e seu ambiente. Por fim, ressalte-se o papel da realidade social, já que nessa concepção teórica, segundo Coelho (2006, p.150), "as raízes das funções psíquicas superiores no homem vão além do organismo biológico: elas se encontram nas condições objetivas de sua existência".

Os modelos sistêmicos encontram, segundo Coelho (2006), certa dificuldade devido ao fato de exigirem processos experimentais novos, que permitam confrontar objetos e conceitos provenientes de diferentes campos de investigação. Tal dificuldade se traduz no fato de que a atividade do cérebro se expressa em diferentes níveis, nos quais intervêm variáveis de diversas naturezas. Tal complexidade é maior ainda nos processos psíquicos, já que nesses intervêm variáveis sociais e biológicas. Além disso, Coelho (2006, p.153) aponta a “correlação entre o amadurecimento das funções neuronais e a expressão evolutiva de processos psíquicos", que não se articulam através de uma relação simples de causa e efeito. Desta forma, não é possível afirmar que a atividade neural de certas regiões cerebrais “determine categorias equivalentes aos conceitos psicológicos, mas apenas é possível estabelecer articulações específicas entre a expressão funcional da atividade cerebral e a expressão mais complexa dos processos psíquicos", não sendo admissível transpor funções cerebrais para comportamentos humanos de forma direta, já que se trata de processos concebidos a partir de critérios distintos. Coelho (2006) aponta, a partir disso, a necessidade de construir interconceitos para auxiliar na compreensão da articulação entre atividade cerebral e dinâmica psíquica, o que exige estudos interdisciplinares que possam levar em consideração as contribuições da perspectiva histórico-cultural.

A seguir, apresenta-se uma discussão específica sobre as relações entre neurociência e educação tais como vêm sendo produzidas na atualidade, tentando-se compreender este fenômeno na perspectiva da psicologia histórico-cultural e, dessa forma, oferecer algumas possíveis contribuições dos conceitos discutidos até o momento para a educação. 


\section{NEUROCIÊNCIA E EDUCAÇÃO SOB O ENFOQUE DA PSICOLOGIA HISTÓRICO-CULTURAL}

A história, ao mudar o tipo humano, depende do córtex;
o novo homem socialista será criado através do córtex;
a educação é, em geral, uma influência sobre o córtex. $\left(\right.$ Vigotski $\left.i^{53}\right)$

O local é a conferência da fundação TED ${ }^{54}$ (Technology, Entertainment, Design) que aconteceu na Índia em novembro de 2009. No palco, a neurocientista britânica de ascendência indiana Aditi Shankardass, especializada em neurofisiologia, neuroanatomia e neuropsicologia, e atualmente à frente do Laboratório de Neurofisiologia do Departamento de Distúrbios da Comunicação da Universidade Estadual da California, segundo informa o site da TED. O título da palestra é: “Uma segunda opinião sobre distúrbios de aprendizagem ${ }^{55}$ ".

Shankardass inicia relatando que uma em cada seis crianças sofre de algum tipo de distúrbio do desenvolvimento, exemplificado por ela como retardo mental, distúrbios de aprendizagem, dislexia, distúrbios da fala, transtorno de atenção, autismo, síndromes genéticas, epilepsia e distúrbios do sono, o que acaba gerando um atraso no desenvolvimento intelectual da criança. A palestrante relata sua perplexidade com o fato de que, apesar destes distúrbios terem sua origem no cérebro, a maioria deles é diagnosticada apenas com base na observação do comportamento. Shankardass assinala que diagnosticar um distúrbio cerebral

\footnotetext{
${ }^{53}$ apud WOLFE, 2011, p.370.

${ }^{54}$ A proposta das chamadas TED Talks é a disseminação de ideias através de palestras com no máximo dezoito minutos de duração, feitas por personalidades com destacado reconhecimento em diversas áreas, e que posteriormente são disponibilizadas na internet obtendo uma significativa divulgação (a palestra referida aqui teve cerca de 365 mil acessos até dezembro de 2011).

${ }_{55}^{5}$ No original: “Aditi Shankardass: A second opinion on learning disorders". Disponível em: $<\mathrm{http}: / /$ www.ted. com/ talks/ aditi_shankardass_a_second_opinion_on_learning_disorders.html>. Acesso em 17 nov. 2011.
} 
sem olhar para o cérebro é como tratar um paciente cardíaco apenas com base em seus sintomas físicos, sem realizar um raio $\mathrm{X}$ do tórax ou um ECG (eletrocardiograma). Ela conclui dizendo que para fazer um diagnóstico preciso seria necessário olhar o cérebro diretamente, lamentando o fato desse tipo de diagnóstico permanecer limitado à esfera clínica diante de tantos avanços tecnológicos da medicina.

A palestrante relata a experiência de sua equipe na Universidade Harvard na aplicação de tecnologias avançadas no diagnóstico de crianças com esse tipo de distúrbio utilizando a técnica do eletroencefalograma (EEG). Shankardass explica que este exame monitora em tempo real a atividade elétrica cerebral, o que possibilita olhar diretamente o cérebro enquanto realiza diversas funções e diagnosticar, segundo ela, "a menor anormalidade em qualquer função”, ou seja, na visão, atenção, linguagem e audição. O sistema utiliza um programa para mapeamento da atividade elétrica do cérebro em associação com um programa para mapeamento estatístico, de forma a determinar se a anormalidade observada é clinicamente significativa.

Na sequência, Shankardass apresenta o caso clínico de Justin Senigar, um menino norte-americano de sete anos de idade diagnosticado com autismo severo, cujos médicos emitiram prognósticos pessimistas para a família quanto a suas possibilidades de se comunicar ou interagir socialmente (a palestrante informa que o caso foi objeto de reportagem da rede norte-americana de televisão ABC News). Depois de passar pelos exames descritos pela doutora Shankardass, concluiu-se que Justin não era autista, e sim sofria de convulsões cerebrais imperceptíveis a olho nu. Após ser medicado, rapidamente demonstrou progressos, passando de um vocabulário de duas ou três palavras para trezentas palavras em apenas sessenta dias. Os vídeos apresentados pela palestrante, com Justin antes e depois do tratamento, são realmente impressionantes. A doutora Shankardass conta que Justin teve tal melhora que foi até matriculado em uma "escola normal" (sic) e virou campeão de caratê. A palestrante argumenta que várias crianças recebidas em sua clínica e anteriormente diagnosticadas com autismo, "retardo mental" (sic) ou Transtorno do Déficit de Atenção Hiperatividade (TDA-H) e de dislexia sofriam na realidade de problemas cerebrais específicos que não poderiam ser detectados em avaliações comportamentais convencionais. Shankardass conclui dizendo: "mas agora estamos em uma nova era da neurociência, em que podemos finalmente olhar diretamente para as funções cerebrais em tempo real sem riscos ou efeitos colaterais, de forma não invasiva, e encontrar a verdadeira fonte de tantas deficiências em 
crianças", aspirando desta maneira que uma criança diagnosticada de forma errada ou ainda sem diagnóstico possa enfim libertar-se e atingir seu potencial verdadeiro, "enquanto ainda é tempo para seu cérebro se recuperar, e tudo isso simplesmente olhando para suas ondas cerebrais".

Aditi Shankardass causou bastante impacto com esta palestra entre profissionais e familiares de crianças com algum tipo de distúrbio do desenvolvimento. A técnica do EEG relatada aparentemente não é nova, mas não há muitas informações técnicas disponíveis sobre ela. Em uma busca na base de dados PubMed, que indexa periódicos em língua inglesa, realizada em novembro de 2011, não se encontra nenhum artigo publicado por Shankardass ou algum de seus colaboradores. Em pesquisa na base de dados Google Acadêmico também não se obtém maiores informações. É possível encontrar a referência de sua tese Neurophysiological evidence of sensory and cognitive deficits in dyslexia, com data de 2003, na base de dados da Universidade de Sheffield, mas não há acesso ao resumo ou ao texto completo. Na Internet, a maior parte dos hiperlinks que citam Shankardass relaciona-se com a palestra no TEDIndia.

Em que pese a falta de maiores informações sobre a produção acadêmica da neurocientista, e ainda que a descrição da palestra de Shankardass seja um pouco longa, esta apresentação merece ser feita por ir de forma exemplar ao encontro do tema debatido neste capítulo. O ponto fundamental a ser destacado é a crítica da neurocientista à imprecisão do diagnóstico clínico, baseado em informações e observações sobre o comportamento da criança, propondo substituí-lo pelo olhar "direto" para o cérebro. Mesmo considerando que o que Shankardass de fato está defendendo com o emprego da técnica apresentada por ela é a eliminação da possibilidade de que os problemas da criança estejam relacionados com a atividade epileptiforme do cérebro, não é exagero imaginar alguns possíveis desdobramentos de certa fascinação exercida por sua fala. O principal deles seria a possibilidade de diagnosticar de forma precisa e definitiva, através da tecnologia médica, se uma criança efetivamente tem ou não um distúrbio de aprendizagem. Bastaria submetê-la à avaliação com o EEG, e saber-se-ia ao final se ela tem ou não dislexia, TDA-H ou ainda autismo, com base na tecnologia médica, isenta de julgamentos e portadora de precisão científica inquestionável. Os problemas de muitas escolas e educadores estariam resolvidos: a nova tecnologia separaria o "joio" do "trigo", ou seja, quem "aprende" de quem "não aprende", para que estes últimos 
possam ser tratados e ter seus problemas individuais resolvidos, "enquanto ainda é tempo para seu cérebro se recuperar", como assinalou Shankardass.

A crítica que aqui está sendo feita dirige-se à suposta isenção que tal tipo de diagnóstico médico poderia ter, em evidente desconsideração aos fatores sociais e culturais envolvidos, numa concepção do humano como organismo biológico isolado de seu contexto histórico. É o que se conhece como medicalização, fenômeno definido como o "processo de transformar questões não-médicas, eminentemente de origem social e política, em questões médicas, isto é, tentar encontrar no campo médico as causas e soluções para problemas dessa natureza" (COLLARES; MOYSÉS, 1994, p.25). A concepção que fundamenta essa visão é a organicista, segundo a qual o processo saúde-doença estaria centrado unicamente no indivíduo, de forma descontextualizada, sendo portanto um problema individual, e assim perdendo sua dimensão coletiva ou da inserção social do indivíduo (COLLARES; MOYSÉS, 1994). A partir dessa apropriação, a medicina interfere prescritivamente na construção de conceitos, normas de moral, costumes e comportamentos sociais, o que se dá de forma articulada não somente à aplicabilidade do saber científico à estrutura social, mas também com o crescimento da tecnologia médica, envolvendo métodos de diagnóstico e tratamento, assim como a indústria farmacêutica, tudo isso perpassado por concepções políticas e ideológicas quanto à concepção de saúde e adoecimento (LUZ, 1988, 1997).

O recorte específico aqui realizado em relação a essa concepção biologizante do indivíduo é o que envolve a questão do cérebro, ou ainda da neurociência, em sua relação com a educação. Afinal, o conhecimento sobre o cérebro pode auxiliar a educação? Como a neurociência pode se articular com a educação, uma vez que se trata do encontro de dois campos epistemológicos diferentes e tradicionalmente distantes, entre uma dita "ciência dura" e por vezes reducionista como a ciência neurológica, e a educação, de caráter mais humanista? Será que a neurociência pode trazer contribuições à educação que superem a descrição de supostos distúrbios como TDA-H e dislexia, podendo informar os educadores sobre os processos cerebrais envolvidos na aprendizagem? E essa informação, por sua vez, pode contribuir para o processo educacional, efetivamente transformando as práticas em sala de aula? Ou pode se transformar em uma nova forma de rotulação de alta tecnologia, envolvendo ressonâncias magnéticas e pesquisas moleculares? Essas são algumas das questões que se pretende debater aqui, a partir de um enfoque baseado na psicologia históricocultural proposta por Vigotski. 
Esse capítulo faz esta discussão obedecendo à seguinte organização: após a contextualização inicial do problema, discute-se como a relação entre neurociência e educação tem se dado atualmente, destacando os principais debates neste tema. Em seguida, apresenta-se algumas opiniões de pesquisadores desse campo quanto às possibilidades de tal "casamento" (para usar um termo presente nesta literatura), com opiniões favoráveis e críticas. Depois, discute-se a ideia de uma educação baseada em evidências, o que isso significa e como se articula com a questão neurociência e educação. Por fim, debate-se os temas levantados nesta análise iluminados pela psicologia histórico-cultural de Vigotski, a partir da qual apresenta-se algumas conclusões possíveis resultantes desta reflexão.

\subsection{Neuromitos - ou da voracidade da educação sobre a neurociência}

A discussão sobre relações entre neurociência e educação ainda é tímida e ensaia seus primeiros passos no Brasil, situação muito diferente do que ocorre em outros países, como os Estados Unidos da América (EUA), por exemplo ${ }^{56}$. O mercado norte-americano está repleto de publicações e métodos de treinamento sobre "brain-based learning", ou aprendizagem baseada no cérebro. Obviamente, é um mercado financeiramente interessante, haja vista a crescente quantidade de produtos lançados a cada ano, como materiais didáticos e assessorias, que se pode conhecer em uma pesquisa simples na Internet. É interessante observar que tipo de promessa tais materiais fazem, de forma a alcançar tanto sucesso junto a educadores, apesar de basearem-se em evidências científicas bastante frágeis, como se poderá ressaltar.

\footnotetext{
${ }^{56}$ A maior parte dos autores que pesquisam a interface neurociência e educação aqui citados são estrangeiros, já que essa área de pesquisa ainda é incipiente no Brasil. Adotou-se como critério de escolha das obras analisadas nesse capítulo o fato de terem sido publicadas em livros e manuais (handbooks), mas principalmente em periódicos científicos internacionais, os quais obedecem rigorosas regras de publicação, como por exemplo a revisão por pares. Alguns desses periódicos internacionais são: Cortex, Educational Research, Educational Theory, Journal of Interactive Learning Research, Journal of Philosophy of Education, Mind, Brain, and Education, Nature, Nature Reviews Neuroscience, Neuron, Revista de Neurología, Revista Española de Neuropsicología, The Neuroscientist, Trends in Cognitive Sciences e Westminster Studies in Education.
} 
Um dos principais fatores para o avanço da pesquisa sobre o cérebro foi o desenvolvimento de avançadas técnicas de exame, como a neuroimagem funcional, que permite o exame do cérebro vivo em funcionamento durante a execução de uma dada tarefa. Estas medidas baseiam-se no fluxo do sangue através do cérebro, sendo as regiões mais ativas aquelas que apresentam maior fluxo sanguíneo. Exames como a ressonância magnética funcional (fMRI, na sigla em inglês) e tomografia por emissão de pósitrons (PET, na sigla em inglês) baseiam-se nestas medidas. Outro exame utilizado nas pesquisas sobre o cérebro é o já citado eletroencefalograma (EEG), que mede a atividade eletromagnética na superfície do cérebro. Também se utiliza a técnica da estimulação magnética transcraniana (EMT), através da qual se estimula uma determinada região do cérebro interrompendo momentaneamente sua atividade, utilizada para identificar a localização de determinadas funções cerebrais (BLAKEMORE; FRITH, 2000). Contudo, Fischer, Goswami, Geake et al. (2010) alertam que realizar inferências sobre o comportamento a partir da observação atividade cerebral é uma tarefa complicada, exigindo uma análise estatística muito mais cuidadosa dos dados oferecidos pelos exames de imagem cerebral do que é comumente assumido, já que a maioria dos comportamentos envolve múltiplas regiões do cérebro, sendo portanto quase impossível assegurar que tipo de atividade mental está sendo realizada apenas pela observação dos exames de imagem cerebral de uma determinada pessoa.

Ainda assim há, sem dúvida alguma, um fascínio exercido pelas questões relacionadas ao cérebro nos dias atuais. Goswami (2008) relata os interessantes achados de Weisberg et al. (apud GOSWAMI, 2008) ao submeterem a dois grupos distintos explicações superficiais para fenômenos psicológicos, sendo que para um dos grupos as explicações eram acompanhadas por dados neurocientíficos irrelevantes para o que estava sendo relatado. No entanto, o grupo que teve acesso aos dados neurocientíficos classificou as explicações como mais adequadas, o que levou Weisberg e colegas a concluir que as explicações apoiadas na neurociência são sedutoras e levam com mais facilidade à suspensão do juízo crítico sobre os fatos apresentados.

Goswami (2006) observa que há uma voracidade por parte dos educadores para colher os frutos anunciados pela neurociência. Ainda que progressos estejam sendo feitos no conhecimento dos processos envolvidos na alfabetização e na aprendizagem matemática, por exemplo, eles ainda são predominantemente teóricos. A lacuna entre o laboratório e a sala de aula acaba sendo preenchida com produtos que anunciam ser baseados na ciência do cérebro. 
Goswami (2006) cita alguns exemplos interessantes. Um curso para professores orientava a identificar os alunos como sendo de "lado esquerdo" ou "lado direito" do cérebro, baseado na suposição de que os alunos "preferem" um tipo de processamento, o que se fundamentaria numa provável interpretação literal da especialização hemisférica. Os professores são aconselhados a equilibrar as atividades da sala de aula com características dos dois lados do cérebro, para evitar um desencontro entre o suposto referencial do aluno e a aprendizagem. Outro curso orienta os professores a identificar os alunos como "Visual", "Auditivo" ou "Cinestésico", utilizando etiquetas com as letras V, A ou C para orientar os professores no trabalho com eles. Outro pacote comercial intitulado "Brain Gym" (Ginástica Cerebral) orienta a realização de alguns movimentos corporais com o objetivo de "integrar todas as áreas do cérebro para melhorar a aprendizagem”, de forma que os estudantes acessem áreas do cérebro que antes estavam "fora do seu alcance", ou ainda orientam que a criança aperte "botões do cérebro" localizados sob as costelas para focar o sistema visual na leitura e escrita.

Ainda que não haja nenhuma pesquisa que comprove os benefícios de tais atividades, elas geralmente são consideradas pelos educadores como evidências científicas, e categorizadas como novas tecnologias baseadas no cérebro colocadas a favor do ensino. Mas por que isso acontece? Para Geake (2008), esta aceitação acrítica mereceria por si só um estudo, refletindo que algumas justificativas possíveis seriam a pressão política para a obtenção de resultados rápidos e um melhor desempenho nas avaliações do sistema a fim de alcançar uma melhor posição no "ranking" de escolas. O autor lamenta que, com essa busca de recursos pedagógicos de "tamanho único", fique obscurecida aos olhos do professor as diferenças em que sua sala de aula é rica, possibilitando um trabalho muito mais criativo e efetivo.

Esse tipo de ideia falaciosa é chamado de neuromito. A origem dos neuromitos justifica-se pelo próprio ritmo em que a ciência é construída, através de tentativas e erros. Uma nova teoria contradiz ou completa a anterior, e assim se faz o progresso do conhecimento científico. No entanto, mesmo que alguma hipótese seja desmentida, ela pode deixar traços, principalmente se captura de alguma forma a imaginação do público ao ser divulgada pelos meios de comunicação (OECD, 2007). Assim nasce o neuromito, e a própria ciência encontra dificuldades para refutá-lo, uma vez que sua permanência não se dá por razões científicas, e sim por ter adquirido entusiastas em torno de si (GEAKE, 2008). 
Alguns exemplos de neuromitos são: "Nós só usamos 10\% da nossa capacidade cerebral"; "O cérebro do homem é diferente do da mulher"; "Tudo que é importante no desenvolvimento cerebral acontece até os três anos, portanto não há tempo a perder"; "Eu funciono mais com o cérebro-direito, ele é mais cérebro-esquerdo"; "Todos têm um canal prioritário: visual, auditivo ou cinestésico"; "A neurociência comprovou a existência das múltiplas inteligências", entre outros (GEAKE, 2008; OECD, 2007). Um episódio interessante para demonstrar a força que pode ter um neuromito é o chamado "Efeito Mozart". Em 1993, dois pesquisadores da Universidade da Califórnia, Gordon Shaw e Frances Rauscher, fizeram um experimento com estudantes universitários, no qual um grupo escutava a Sonata para Dois Pianos em Ré Maior (K.448) de Mozart, e o outro não, após o que ambos os grupos eram testados com tarefas similares às de testes de inteligência, sendo encontrada uma melhora de desempenho temporária no grupo que ouviu Mozart. Embora outros pesquisadores não tenham conseguido repetir estes resultados (o que torna as conclusões do estudo não fundamentadas), isso não impediu que a pesquisa ganhasse grande popularidade, chegando ao ponto em que os governos dos estados norte-americanos do Tennessee e da Geórgia viessem a distribuir um CD de Mozart para cada recém-nascido (CARROLL, 2001).

Apesar desse episódio ser quase cômico, revela o tipo de mau uso dos recursos públicos a que as concepções equivocadas sobre o cérebro pode levar, como se fosse possível evitar problemas de desenvolvimento na infância por uma estimulação precoce isolada dos contextos de desenvolvimento da criança. O fato é que o cérebro, hoje em dia, não é mais um assunto restrito às escolas de medicina, e o tema tem uma circulação social garantida pela divulgação da mídia. Programas de televisão e revistas semanais alardeiam novos tratamentos, medicamentos e orientam quais alimentos consumir para que o cérebro funcione melhor, entre outras possibilidades. No dia seguinte a estas reportagens, os pacientes procuram seus médicos querendo os tais medicamentos, e nas feiras e supermercados ninguém consegue encontrar mais o tal alimento alardeado da reportagem, que obviamente sofreu um aumento de preço. Ou seja, a popularização da neurociência pode ser considerada uma parte influente do tecido social em nossos tempos midiáticos - oferecida, obviamente, de forma banalizada, superficial e sem maiores questionamentos, o que obviamente está longe de ser verdadeiro. 


\subsection{Neurociência e medicalização na escola}

Mas e quando esse fenômeno chega à escola? Já se apontou acima a questão da medicalização da sociedade - como parte integrante dela, a escola também repercute esses sintomas. Os exemplos mais notáveis são a disseminação dos diagnósticos de TDA-H e de dislexia. Os problemas de escolarização são tomados como resultado da ação de atores individuais - no caso, o aluno, que carrega em seu corpo (ou em seu cérebro) a fonte dos problemas. As demais possibilidades envolvidas num processo de extrema complexidade como é a escolarização - como a política curricular do sistema de ensino, a qualidade das intervenções didáticas, as condições estruturais da escola, a desvalorização da carreira docente e outros inúmeros fatores - são convenientemente descartadas, uma vez que parece haver pouco a fazer nesse sentido, e o aluno acaba sendo encaminhado cada vez com maior frequência ao neurologista ou ao psiquiatra, de onde dificilmente sairá sem uma prescrição de medicamento. Ou seja, o aluno é transformado em paciente neurológico, suposta vítima das “doenças do não-aprender” (MOYSÉS; COLLARES, 2010).

$\mathrm{O}$ fato de ambos diagnósticos - de TDA-H e dislexia - serem bastante controvertidos, com uma parcela da comunidade científica apresentando sérios questionamentos a sua existência enquanto distúrbios de aprendizagem, não impede que esses diagnósticos sejam cada vez mais comuns e acompanhados, obviamente, de medicação. O metilfenidato, princípio ativo da Ritalina e do Concerta, medicamentos utilizados no tratamento de TDA-H, teve um aumento de $1.616 \%$ no número de caixas vendidas por ano no Brasil, pulando de 71.000 caixas em 2000 para 1.147.000 caixas em 2008 (dados do Instituto de Defesa dos Usuários de Medicamentos - IDUM, apud MOYSÉS; COLLARES, 2010).

Moysés e Collares (2010) criticam a divulgação equivocada de que a neuroimagem traria a certeza para a existência do TDA-H e da dislexia ${ }^{57}$. Segundo as autoras, não há embasamento científico para essa afirmação, uma vez que os controles estatísticos são sobre amostragens muito pequenas, e os resultados em exames anatômicos de cérebros são inconclusivos (GALABURDA, 1987 et al, apud MOYSÉS; COLLARES, 2010). O mesmo

\footnotetext{
${ }^{57}$ Divulgação no site da Associação Brasileira de Dislexia - ABD de declaração de Ana Beatriz Barbosa e Silva, psiquiatra e escritora, apresentada no $8^{\circ}$ Simpósio Nacional de Dislexia, conforme Moysés e Collares (2010, p.83).
} 
vale para as tentativas de encontrar um gene responsável por esses distúrbios. O argumento da neuroimagem é bastante discutível: se uma criança tem dificuldade na leitura, é óbvio que irá apresentar uma menor ativação nas áreas cerebrais relacionadas à leitura, pois é justamente essa a tarefa solicitada à criança durante a realização dos exames de ressonância magnética funcional (fMRI) utilizados em muitas pesquisas atualmente: que a criança leia (MOYSÉS; COLLARES, 2010).

Tem-se aí duas ocorrências que devem ser destacadas. Primeiro, o uso de tecnologias de neuroimagem no diagnóstico dos supostos distúrbios de aprendizagem, o que deixa claro que tais pesquisas partem da premissa de que se trata de um problema localizado no cérebro do aluno, com pouca ou nenhuma preocupação com fatores sócio-ambientais que possam influenciar esses resultados. Aqui se pode recorrer a um princípio básico da psicologia histórico-cultural, que é o papel do meio na formação do psiquismo. Há pouca preocupação, nesse tipo de pesquisa, em procurar outros componentes para enriquecer a compreensão da história individual justamente pela perspectiva a-histórica adotada: qual foi o trajeto daquela criança até ter seu cérebro examinado? Como foram suas experiências de aprendizado? Pode este cérebro ser compreendido de forma isolada da pessoa como um todo e sua história? É claro que isso descortina uma complexidade dificilmente conversível em dados científicos, mas ignorá-la não tem ajudado a esclarecer os caminhos que a aprendizagem da leitura e da escrita percorre em cada indivíduo, bem como tem servido a alguns interesses escusos, como os da indústria farmacêutica. A segunda ocorrência é um dilema no estilo "ovo-galinha": quem veio primeiro? O cérebro tem um funcionamento comprometido inato nas áreas relacionadas à leitura e escrita, e daí surge a dificuldade no processo de alfabetização, ou o processo de alfabetização foi problemático, resultando em um funcionamento comprometido do cérebro nas áreas relacionadas à leitura e escrita? Assim como o dilema do ovo e da galinha, esse dilema não tem respostas fáceis, e a busca por elas acaba sendo influenciada pelas concepções dos pesquisadores e das agências financiadoras a respeito das relações entre ambiente e genética.

Nesse sentido, é interessante citar um estudo recente realizado com pessoas que foram alfabetizadas na idade adulta (CARREIRAS et al., 2009), publicado na prestigiada revista científica Nature. O estudo utilizou adultos como parte do desenho experimental, pois, segundo os autores, ao pesquisar a atividade cerebral relacionada com a aprendizagem da leitura e escrita é problemático utilizar crianças como sujeitos, uma vez que não se pode 
afirmar com certeza que as eventuais mudanças observadas no cérebro se devem àquele aprendizado específico, uma vez que a criança se encontra numa fase de intensas e variadas aprendizagens, com um cérebro em expressivo desenvolvimento (um cuidado que algumas das pesquisas mencionadas por Moysés e Collares, 2010, sobre dislexia parecem não ter tomado). Ao comparar a atividade cerebral dos adultos alfabetizados com um grupo controle de adultos não alfabetizados, os pesquisadores encontraram uma ativação das áreas relacionadas à leitura e escrita nos alfabetizados, ainda que a alfabetização tenha ocorrido na fase adulta. Esse estudo fomenta algumas reflexões interessantes. Em primeiro lugar, aponta a questão da plasticidade cerebral, indicando que o aprendizado pode ocorrer mesmo fora dos "períodos críticos" para a aprendizagem (um conceito discutível no caso dos humanos, onde é preferível falar em "períodos sensíveis", conforme OCDE, 2007). E a segunda conclusão é de que as áreas relacionadas com a leitura e escrita nos adultos não alfabetizados estavam atrofiadas ou não desenvolvidas justamente porque eles não haviam aprendido a ler, e não o contrário, ou seja, que uma suposta atrofia explicaria seu analfabetismo. Uma vez que foram ensinados, eles aprenderam, e seu cérebro modificou-se em função disso. Portanto, aprender modifica o cérebro, ou seja, aprender produz desenvolvimento. Ora, essa hipótese foi lançada por Vigotski há cerca de oitenta anos, quando postulou a inversão da relação entre desenvolvimento e aprendizagem proposta pela psicologia tradicional, segundo a qual primeiro deve haver desenvolvimento de forma a possibilitar a aprendizagem - como pode ser exemplificado por um tipo de frase (infelizmente bastante comum nas escolas) como "esta criança ainda não está madura para aprender a ler”. Vigotski nega essa presunção, afirmando justamente o contrário: a aprendizagem gera o desenvolvimento, e o bom ensino deve se adiantar em relação ao que o aluno já sabe. Esta é a base de seu conhecido conceito de zona de desenvolvimento proximal (VIGOTSKI, 1933/1992).

\subsection{Uma longa ponte}

Uma vez que já se discutiu os neuromitos e a recorrência a argumentos neurológicos para justificar a não aprendizagem, cabe discutir agora o outro lado, ou seja, das possíveis contribuições da neurociência para a educação. A tentativa de aproximar neurociência e educação não é nova. Henry Herbert Donaldson (1857-1938), um neurologista, 
publicou em 1895 um trabalho intitulado The growth of the brain: a study of the nervous system in relation to education (em tradução livre, O crescimento do cérebro: um estudo do sistema nervoso em relação com a educação), e Reuben Post Halleck (1859-1936), um educador, publicou na mesma época, em 1886, o trabalho The education of the central nervous system: a study of foundations, especially of sensory and motor training (em tradução livre, A educação do sistema nervoso central: um estudo dos fundamentos, especialmente o treinamento sensorial e motor), podendo ser consideradas umas das primeiras tentativas de interlocução neste campo interdisciplinar (THEODORIDOU; TRIARHOU, 2009).

As possíveis relações entre neurociência e educação não apenas têm atraído a atenção de pesquisadores de ambos os campos, mas também dos responsáveis por políticas públicas, com foco numa utilização possível das investigações da neurociência para o aprimoramento do processo ensino aprendizagem (RATO; CALDAS, 2010). Muitos estudos foram publicados nos EUA impulsionados pela chamada Década do Cérebro, período compreendido entre 1990 e 1999, assim denominado por um decreto do presidente George H. W. Bush (pai), visando incentivar principalmente pesquisas nas áreas da demência, abuso de drogas e saúde mental, entre outros temas, entre os quais se pode incluir publicações investigando possíveis contribuições da neurociência para a educação. Em 1996 ocorreu um encontro entre especialistas nos campos de neurociência e educação promovido pela Education Commission of the States e pela Dana Foundation em Denver, nos EUA, onde foi disparado um intenso debate sobre a viabilidade ou não da aplicação dos achados da neurociência para a educação (BRANSFORD et al., 2005; BENARÓS et al., 2010).

Uma publicação que pode ser considerada um marco nesta literatura é o texto de John Bruer (filósofo e atual presidente da Fundação James S. McDonnell Foundation, que apoia projetos de pesquisa em ciências e educação) publicado em 1997, no qual ele propõe que entre neurociência e educação haveria uma ponte muito grande a ser percorrida, no que se refere à efetivação de mudanças na sala de aula com base em fundamentos neurocientíficos. Para ele, a articulação possível se daria entre a educação e a psicologia cognitiva, que pode embasar o desenvolvimento de uma ciência aplicada da aprendizagem e do ensino (BRUER, 1997; BLAKEMORE; FRITH, 2000). A partir daí, o termo "ponte" tornou-se uma referência comum na discussão sobre as possíveis articulações entre neurociência e educação (BENARÓs et al., 2010). 
A possibilidade de contribuições mutuamente benéficas dependeria de que uma área não se sobrepusesse à outra, mas que ambas se esforçassem na construção de uma linguagem comum e transdisciplinar, no sentido em que de tal colaboração possa emergir uma nova disciplina, como propõe Koizumi (2004, apud RATO; CALDAS, 2010). Alguns nomes já foram propostos para esta nova disciplina. O termo neuroeducação foi introduzido por Battro e Cardinali em artigo publicado em 1996 (THEODORIDOU; TRIARHOU, 2009), e mais atualmente Mente, Cérebro e Educação ("Mind, Brain and Education”, FISCHER et al., 2007), Neurociência Educativa ("Educational Neuroscience”, GOSWAMI; SZÜCS, 2007) ou ainda Neuroaprendizagem (RATO; CALDAS, 2010).

É claro que uma comunicação seria mais efetiva com a utilização de um vocabulário comum entre neurocientistas e educadores (BLAKEMORE; FRITH, 2000) e a proposição conjunta de questões a serem investigadas, de forma a corresponder aos problemas reais da escola (RATO; CALDAS, 2010). Mas principalmente, para que tal parceria seja bem sucedida, é preciso desmistificar junto aos educadores a ideia de que a neurociência trará soluções rápidas e prescritivas para a educação, por mais atraente que tal ideia pareça. Portanto, a expectativa de que o professor possa utilizar métodos pedagógicos embasados em dados neurocientíficos não será suprida pela neurociência, mas pode advir de um trabalho comum entre os dois campos (BLAKEMORE; FRITH, 2000; RATO; CALDAS, 2010). A construção de um campo de pesquisa conjunto pode ser a forma de integrar conhecimentos práticos escolares e pesquisa científica. Ler um livro na escola é muito diferente de ler pseudo-palavras em um aparelho de ressonância funcional magnética durante um estudo sobre tempo de reação: o conhecimento não pode ser transferido de forma descontextualizada de uma instância à outra, mas pode ser mediado por uma articulação entre pesquisa e prática (FISCHER et al., 2007).

Mesmo reconhecendo a distância atual entre uma aplicação prática dos conhecimentos atualmente disponíveis sobre o cérebro, alguns autores defendem a possibilidade de que determinadas abordagens pedagógicas possam ser afins com estes princípios, como por exemplo a aprendizagem baseada em problemas e o estudo de casos, por envolverem um estudo contextualizado, supostamente mais identificado à maneira com a qual o cérebro humano constrói conhecimentos (BLAKEMORE; FRITH, 2000; HUNG, 2003).

Geake e Cooper (2003) referem que as discussões têm se polarizado nos seguintes campos: de um lado, estão aqueles que defendem que a neurociência deve se manter longe da 
educação, enquanto que, do outro lado, estão os que defendem uma aproximação entre neurociência e educação de forma mais prudente do que o entusiasmo inicial, repleto de ideias pouco realistas. Nesta polarização, os autores defendem o caminho do meio, com um otimismo cauteloso quanto ao possível desenvolvimento das relações entre neurociência e educação a longo prazo.

Para alguns autores, a mediação entre os dois campos pode ser exercida pela psicologia cognitiva, como sugerem Bruer (1997) e Blakemore e Frith (2000). Bruer (1997) define a psicologia cognitiva como a área que estuda a mente e o funcionamento mental sem necessariamente preocupar-se com estruturas e funções cerebrais. O primeiro passo seria considerar como a psicologia cognitiva tem contribuído para a pesquisa em educação, como no exemplo citado por Bruer (1997) da pesquisa sobre cognição matemática. A partir dessa ligação, então, poderia ser construída a ponte entre a cognição e os sistemas cerebrais. Ainda assim, na opinião do autor, não fica claro como se pode avançar em relação a uma aplicação em sala de aula desses resultados - como exemplo, cita que não é possível entender como o cérebro processa números apenas observando uma criança na sala de aula, muito menos se poderia basear um currículo a partir de experimentos com cognição matemática. Para Bruer (1997), a psicologia cognitiva é mais útil, pois tem ajudado a resolver questões educacionais e a planejar formas de instrução mais adequadas. A psicologia cognitiva, como campo de pesquisa para neurocientistas cognitivos, contribui também para o entendimento de como as estruturas neurais viabilizam as funções cognitivas, e poderia fazer portanto uma mediação entre neurociência e educação.

Geake e Cooper (2003) propõem que esta mediação seja feita pela neurociência cognitiva, pois reconhecem que há um potencial de contribuição para a educação a partir de uma interpretação ou generalização dos dados neurocientíficos. Os autores defendem que tal contribuição não deve ser uma guinada ao determinismo biológico, e sim uma base para uma concepção educacional baseada no humano em suas dimensões biopsicossociais. Definem a neurociência cognitiva como um campo de estudos que abrange uma variedade de abordagens e paradigmas experimentais, desde o biomolecular ao comportamental, de temas como visão, cognição espacial, emoções, imitação, linguagem, consciência e outros que podem trazer informações importantes para a educação, relacionadas por exemplo a inteligência, aprendizagem, memória e criatividade, entre diversas possibilidades (GEAKE; COOPER, 2003). Para eles, um possível benefício para os educadores decorrente de uma articulação com 
a neurociência cognitiva é a possibilidade de sair de uma posição à margem e ocupar o lugar de reconhecimento como sendo as pessoas mais competentes para conhecer as necessidades dos alunos, passando a influenciar a pesquisa cognitiva com suas demandas, como por exemplo sobre as práticas educativas mais efetivas para preparar as crianças e jovens para as demandas da sociedade atual. Os autores defendem que reconhecer as contribuições da biologia para o desenvolvimento humano contribuiria para a compreensão deste emaranhado de fatores interrelacionados que caracteriza o mundo de hoje. Observam que tanto cientistas sociais quanto naturais na segunda metade do século 20 rejeitaram explicações biológicas da sociedade humana em favor de explicações de caráter sócio-cultural, ficando as explicações biológicas associadas a questões reprováveis como a eugenia, por exemplo, e instaurando-se uma distância entre os argumentos biológicos e os sociais, históricos e culturais, distância que desconsidera os avanços do pensamento sobre saúde mental, que focalizam com particular ênfase o papel do ambiente na prevenção e tratamento de desordens mentais (DEGLER, 1991; STEVENS; PROCE, 1996, apud GEAKE; COOPER, 2003).

Desta forma, produzir ambientes mais saudáveis seria fundamental para o desenvolvimento e para a aprendizagem. No entanto, esses apontamentos também favorecem interpretações equivocadas sobre as práticas educacionais que favoreceriam o desenvolvimento cerebral dos alunos, como programas do tipo do já citado Brain-Gym, que, segundo Geake e Cooper (2003), é bastante popular no Reino Unido, a despeito de apoiar-se em bases científicas discutíveis ou mesmo inexistentes. Tais usos, no entanto, sugerem a necessidade de pesquisas neste campo, buscando entender este fenômeno de adesão acrítica bem como a forma como a neurociência tem sido incorporada pelas escolas, professores, universidades e alunos. Mesmo assim, Geake e Cooper (2003) defendem que tais simplificações de algumas descobertas da neurociência não devem fazer com que se recuse a articulação entre educação e neurociência, mas sim alertar quanto à prudência e a observância dos parâmetros científicos de pesquisa, ainda mais por se tratar da educação. Por mais que ainda pareça uma ponte muito longa a articulação entre educação e neurociência, como apontado por Bruer (1997), a velocidade com que novas descobertas são feitas no campo da ciência, trazendo luz para mecanismos cerebrais até então desconhecidos, insta uma atenção a isso. É possível observar, por exemplo, que anos de escolaridade influem na densidade neuronal, aumentando a estrutura cerebral - a escola, portanto, modifica o cérebro do aluno, e a neurociência cognitiva poderia, na opinião de Geake e Cooper (2003), mostrar o quanto e 
como, o que não significa, segundo os autores, defender uma aprendizagem mecânica, baseada no treino, mas na adoção de práticas fundamentadas no contexto escolar. Por exemplo, citam que um tempo de brincadeira livre antes da introdução de um conteúdo formal pode ser estratégico para introduzir conteúdo formal. Frente a isso, pode-se questionar: é necessário buscar uma fundamentação neurológica para justificar uma prática já bem fundamentada na experiência educacional como essa? Enfim, Geake e Cooper (2003) defendem que o professor se aproprie destes conhecimentos neurocientíficos, argumentando nesta defesa através de um exemplo fictício, onde um professor do futuro recomenda estratégias pedagógicas para melhorar o rendimento de um aluno em matemática a partir da leitura de uma neuroimagem (o que lembra a fala de Shankardass no início do capítulo). Os autores citam como exemplo a profissionalização da medicina, ocorrida a partir de um contexto sócio-cultural no qual o saber médico passa a ser valorizado, defendendo que com a educação poderia suceder o mesmo. O exemplo oposto mencionado por eles é o do professor com formação superficial, que se exime de saber o que acontece com o aluno e o encaminha para algum especialista. Tal ideia fomenta algumas implicações discutíveis: será que isso faria professores melhores? O tipo de respeito social que a profissão médica tem é sem dúvida merecido pela profissão de professor, mas o saber médico e suas práticas são os melhores modelos para a profissão de professor? Não deveria o professor estar comprometido com a emancipação dos seus alunos, do ponto de vista não apenas intelectual mas como pessoas ativas em sua sociedade, valorizadas em sua diversidade, o que parece um tanto incompatível com o modelo baseado em protocolos da medicina? Não encaminhar para o especialista implica que o professor se especialize em neurociência, quando deveria especializar-se na tarefa educativa? São alguns questionamentos possíveis, que reforçam a incipiência em que modelos de aplicação da neurociência na educação como os de Geake e Cooper (2003) ainda demonstram.

Fischer, Goswami, Geake et al. (2010) criticam o ceticismo inaugurado por Bruer (1997), embora não o citem de maneira explícita. Referem que o argumento do distanciamento entre neurociência e educação, apontando a psicologia cognitiva como interlocução possível, pode negligenciar a contribuição da biologia para o processo ensino aprendizagem, o que exemplificam de forma simples como a premência de suprir as necessidades biológicas básicas de sono ou de nutrição do aluno para que possa aprender. Os conceitos biológicos podem contribuir para as situações nas quais ocorrem diferenças de 
aprendizagem, inclusive provenientes de variações orgânicas, como por exemplo os fundamentos da audição ou da visão, o que facilitaria, segundo os autores, os objetivos educacionais, já que as diferenças de aprendizagem permeiam a educação, e o conhecimento de suas bases biológicas poderia iluminar os processos que tais diferenças de aprendizagem envolvem. Para os autores, a relevância da biologia é óbvia quando um professor está lidando com um aluno que tem deficiência visual ou algum dano cerebral, e muitas vezes é também esclarecedor na análise de outros tipos de diferenças de aprendizagem, que vão desde a plasticidade até limitações como a dislexia, ainda segundo Fischer, Goswami, Geake et al. (2010). Frente a essa colocação, não se pode deixar de observar que parece igualmente perigoso a busca de explicações biológicas para a aprendizagem desconsiderando os fatores ambientais e culturais, conforme já se apontou anteriormente.

Para Goswami (2008), a neurociência cognitiva, como o campo de estudos da neurociência relacionado ao funcionamento da mente, pode contribuir para ampliar o conhecimento e entendimento sobre a aprendizagem humana, pela combinação das contribuições da neurociência, particularmente as advindas das pesquisas com imageamento cerebral, com o que está estabelecido pela psicologia cognitiva, uma vez que ambas baseiamse no método científico, ou seja, no teste de hipóteses por abordagens quantitativas. Para a autora, o fato de o cérebro ser o "órgão principal da aprendizagem" justifica a necessidade da educação compreender o cérebro, embora haja resistência dos educadores, segundo ela, por conta disso significar uma aplicação dos modelos médicos à educação. Pelo que se debateu até aqui, a receptividade acrítica dos educadores parece ser um problema muito maior à resistência da aplicação de um conhecimento baseado no modelo médico na educação, diversamente ao que aponta Goswami (2008).

O papel da biologia na aprendizagem tem sido enfatizado pelas pesquisas atuais, mas isso não deve significar, segundo Goswami (2008), que a biologia determina a aprendizagem, e sim que esta é fruto de uma interação complexa entre o indivíduo enquanto organismo biológico e seu ambiente, defendendo que um melhor conhecimento sobre o cérebro pode levar à construção de ambientes mais favoráveis para a aprendizagem. Goswami (2008) obviamente se alinha com os defensores de uma aplicação da neurociência à educação, ainda que, segundo a autora, as informações proporcionadas pela neurociência cognitiva estejam em um estado inicial. Portanto, Goswami (2008) defende a importância de conhecimentos como a poda de conexões cerebrais não utilizadas, a plasticidade dependente 
da experiência e sinaptogênese durante toda a vida, entre outras possibilidades. Como exemplo, cita que o cérebro não evoluiu para que o ser humano fosse capaz de ler, mas esta capacidade pode ser desenvolvida através do recrutamento para a tarefa de estruturas cerebrais que realizam atividades semelhantes, como o reconhecimento de objetos. Assim, o cérebro relaciona certas aprendizagens àquelas relacionadas com sua evolução, codificando funções semelhantes às desenvolvidas na evolução dos primatas (DEHAENE, 2008, apud GOSWAMI, 2008). É interessante notar que as características evolutivas do cérebro são completamente reconfiguradas pelos padrões culturais dominantes, como o aprendizado da leitura e da escrita, de tal forma que se passa a questionar o que estaria "errado" com o cérebro de alguém com dificuldade nesse aprendizado como se a aprendizagem da leitura fosse, em si mesma, uma capacidade biológica evolutiva do cérebro, e não uma aprendizagem cultural.

Goswami (2008) lista alguns princípios de aprendizagem com base em conhecimentos iniciais do que denomina como "neurociência educacional" que já podem ser incorporados, em sua opinião, à prática educacional, como por exemplo: a aprendizagem é crescente e baseada em experiências; a aprendizagem é multissensorial; a aprendizagem é social, e ao longo da vida apresenta plasticidade e compensação, entre outros. Segundo esses princípios, pode-se extrair alguns conhecimentos como a importância do ambiente escolar para a aprendizagem, da organização da informação na sequência adequada para a aprendizagem do aluno, do conhecimento de que o cérebro da criança constrói estruturas conceituais detalhadas apenas observando o mundo em que vive e de que a experiência emocional interfere na aprendizagem.

Um conceito interessante apresentado por Goswami (2008) e que pode ser relacionado com os pressupostos da psicologia histórico-cultural é o fato de que o cérebro é social, com estruturas especializadas para essas interações, como os neurônios espelho, enfatizando a importância da imitação (IACOBONI et al., 2005 apud GOSWAMI, 2008), e a capacidade de inferir estados mentais dos outros e atribuição de intencionalidade nos humanos desde bebês (MELTZOFF, 1995; GERGELY; BEKKERING; KIRALY, 2002, apud GOSWAMI, 2008). A autora aponta que o aprendizado social é mais eficaz do que o individual, reconhecendo o que foi proposto por Vigotski, no sentido da importância das interações sociais para a aprendizagem, em que se destaca a mediação da linguagem que, entre outras coisas, permite às pessoas refletir e mudar seu próprio funcionamento cognitivo, 
pelo processo conhecido atualmente como metacognição e utilização das funções executivas. Goswami (2008) aponta também a releitura feita por Csibra e Gergely (2006) destas ideias, apontando que os seres humanos se adaptaram à transferência de conhecimento cultural importante para membros da mesma espécie, o que ocorre através de um sistema de aprendizagem social específica a que chamam de pedagogia. Tal transferência se dá através da colaboração na zona de desenvolvimento proximal, conforme Goswami (2008) acredita. Segundo Csibra e Gergely (2006), a criança tem mecanismos cognitivos específicos que agem de forma complementar aos mecanismos dos adultos em sua tarefa de ensiná-las. A pedagogia é entendida em um contexto evolucionário, como uma adaptação específica do ser humano para transferir e receber conhecimento através do ensino a partir de um sistema de comunicação originado da necessidade de fabricar e usar ferramentas mediadas aperfeiçoado socialmente. Essa capacidade de ensinar e de aprender com o ensino é uma adaptação primária, independente, e, possivelmente, filogeneticamente anterior a qualquer idioma ou a capacidade de atribuir estados mentais. Para Csibra e Gergely (2006), portanto, a pedagogia ou aprendizagem social antecede a capacidade de usar instrumentos e o aparecimento da linguagem.

Por fim, Goswami (2008) aponta que a neurociência pode contribuir para a definição de biomarcadores ou marcadores neurais da aprendizagem, identificados quando a experimentação sistemática mostra uma forte correlação entre um processo cognitivo e um processo neural, o que seria útil em relação a processos não diretamente observáveis e portanto são inferidos pela observação do comportamento. Assim, se uma criança corre algum tipo de "risco educacional", como chamado por Goswami (2008), os biomarcadores podem mostrar isso antes de sintomas comportamentais aparecerem, permitindo uma intervenção precoce. Por exemplo, uma criança cujo processamento sensorial está prejudicado, mas ainda não apresentou sintomas comportamentais, poderia beneficiar-se de intervenção precoce. $O$ genótipo e o sangue podem também ser biomarcadores, e têm sido pesquisados nas dificuldades de aprendizagem, em questões como dislexia e TDA-H, segundo Goswami (2008). Tal ideia parece contraditória com uma perspectiva histórico-cultural do desenvolvimento, uma vez que um marcador biológico não poderia determinar de forma isolada o surgimento de uma dificuldade na aprendizagem. As implicações éticas também são importantes, preocupação também pontuada por Goswami (2008), pois tal visão favorece a 
estigmatização da criança, ou ainda um rebaixamento das expectativas em relação a sua aprendizagem.

Ainda assim, Goswami (2008) defende a neurociência cognitiva como podendo oferecer uma base empírica para apoiar ideias já presentes em pedagogia, apoiando-as em evidências científicas. Para a autora, os fatores biológicos, sensoriais e neurológicos devem tornar-se parceiros tão importantes para uma aprendizagem e educação eficaz quanto as influências sociais, emocionais e culturais. Portanto, para uma melhor compreensão desta proposição, é necessário refletir de forma mais atenta sobre o que significa basear a educação em evidências científicas.

\subsection{Educação baseada em evidências}

A valorização econômica e social conferida pela sociedade moderna à educação, segundo Stern (2005), resulta em uma busca constante por melhorias, particularmente pelos responsáveis por políticas públicas, inclusive no que se refere à prática em sala de aula. Dada a importância da tarefa, de acordo com a mesma autora, os responsáveis pela implantação de políticas públicas procuram basear suas decisões em evidências empíricas ao invés de opiniões, modismos e ideologias, como já ocorreu no passado, buscando implantar práticas educacionais "baseadas em evidências", o que, ao coincidir com um período de popularização e interesse sobre as descobertas da neurociência, deriva no debate de como aplicar esses achados à educação.

Para Carew e Magsamen (2010), quanto mais os educadores tiverem acesso aos cientistas e pesquisas de qualidade, mais informados serão, tornando-se consumidores mais críticos de ciência e portanto evitando modismos não baseados em supostas evidências científicas. Além disso, as evidências acumuladas pela neuroeducação, segundo os autores, contribuem para a tomada de decisões importantes como as relativas ao orçamento para a educação, fornecendo informações para a tomada de decisão em políticas públicas.

Mas o que exatamente significa uma prática baseada em evidências no campo da educação? Conforme Thomas (2007), o educador não está em busca de evidências como o fariam um advogado, um físico ou um historiador, portanto, que tipo de evidências busca? Para o autor, uma evidência é uma informação que sustenta ou refuta uma afirmação, e para 
isso deve passar por alguns testes sobre sua relevância (se constitui informação a favor ou contra alguma proposição), suficiência (se corrobora outros exemplos do mesmo tipo) e veracidade (se o processo de coleta está livre de distorções e se possível não contaminado por interesses estabelecidos), como ocorre por exemplo na paleontologia. O processo, contudo, não é simples. O que "funciona" e o que "não funciona" em uma área de atuação são tipos de conhecimento de caráter tácito, intuitivo e acumulado de forma casual pela experiência, tentativas e erros, observação inteligente e perguntas bem formuladas, situado em um contexto social e interpretativo de prática e de pensamento dos criadores, como aponta Eraut (2007).

A ideia de uma prática baseada em evidências surgiu na medicina, na década de 1990, tendo se ampliado e influenciado outros campos, incluindo a educação (HAMMERSLEY, 2007). No entanto, quando se aplica esse tipo de raciocínio à educação ficamos diante de alguns problemas. Hammersley (2007) aponta que a ideia de uma prática baseada em evidências na educação pode levar a falsas e perigosas promessas. Primeiro, porque se privilegia um tipo específico de evidência fundamentada em um tipo específico de pesquisa, geralmente com prevalência do enfoque quantitativo sobre o qualitativo, desconsiderando outras contribuições, principalmente aquelas acumuladas pela experiência pessoal do professor. A prática baseada em evidências reforça a ideia de que se está fazendo o melhor, ou seja, apresenta-se o que "funciona", portanto tudo o que se opõe a esta prática estaria desacreditado, e passa-se a fiscalizar os educadores para que sigam essa regra, em uma simplificação perigosa da relação entre pesquisa e prática, segundo Hammersley (2007). Esse autor defende que os conhecimentos apresentados como fundamentados em pesquisa devem ser olhados com sobriedade e comparados à prática profissional para avaliar as possíveis relações entre estes campos. Também aponta que é significativa a diferença das práticas profissionais da medicina e da educação, ainda que ambas enfrentem problemas complexos e sujeitos a uma multiplicidade de fatores. Na medicina, segundo ele, há menor diversidade de objetivos e a finalidade é mais técnica, podendo-se identificar com maior frequência relações causais relativamente mais simples entre uma intervenção e seu resultado. Na educação, a pesquisa não consegue responder aquilo que se espera de uma prática baseada em evidências, ou seja, o que "realmente funciona" e o que "não funciona" - e tais questões colocadas por são de extrema relevância ao refletir-se sobre a tentativa de articular neurociência e educação. Outro ponto debatido por Hammersley (2007) é acerca do uso das conclusões de pesquisas 
por profissionais e responsáveis por políticas públicas, pois há uma grande probabilidade de ocorrerem erros de interpretação por desconhecimento do campo de pesquisa ao qual um estudo particular se vincula, como também aponta Greenwood (2009), questão especialmente relevante no caso da neurociência.

Uma alternativa utilizada na busca de evidências científicas para subsidiar práticas educacionais é a revisão de pesquisas, que tem a vantagem de apresentar um conjunto delas e não um estudo individualmente, mas esse tipo de revisão não é algo simples de ser feito, principalmente se o que se busca são prescrições práticas, onde se tende a excluir trabalhos de caráter qualitativo mais aprofundados. Obviamente, tal procedimento não garante por si uma utilização correta dessas informações, como já se pode dicutir no que se refere aos neuromitos, uma vez que é difícil avaliar pesquisas que produzem evidências contraditórias a partir de diferentes metodologias. Hammersley (2007) conclui dizendo que embora pareça haver certa unanimidade em apoiar uma prática baseada em evidências, ela provavelmente não resultará em melhorias para a educação, podendo inclusive produzir o efeito oposto, devido às concepções sobre a natureza da pesquisa e da prática envolvidas, uma vez que se supõe que "a pesquisa poderia cumprir um papel muito mais direto em relação à prática do que ela geralmente pode, tendendo a tratá-la como a aplicação do conhecimento baseado em pesquisa, negligenciando o quanto necessariamente envolve julgamentos incertos" (HAMMERSLEY, 2007, p.157).

A partir desses limites, como se pode pensar na atuação dos achados neurocientíficos sobre a prática da sala de aula? Neste sentido, Willingham (2009) aponta a distinção que há entre ciências naturais e artificiais. Para o autor, ciências naturais, como a neurociência, são descritivas e objetivam descobrir princípios de funcionamento traduzíveis de forma objetiva, enquanto as ciências artificiais, como a educação, são normativas e não pretendem descrever o mundo como ele se apresenta, e sim criar um artefato para um objetivo específico dentro de um dado contexto, como um conjunto de orientações e materiais pedagógicos. É possível que as ciências naturais informem as artificiais, mas Willingham (2009) adverte sobre três problemas nesta relação. Primeiro, o problema dos objetivos, onde aqueles das ciências artificiais nem sempre são compreensíveis em termos das ciências naturais, impossibilitando informar sobre eles. Depois, há o problema vertical, ou dos níveis de análise, pois os neurocientistas estudam funções cognitivas isoladas, enquanto o professor lida com os alunos como um todo, sob a influência de diversos fatores. Por fim, o problema 
horizontal refere-se ao fato de que a teoria educacional baseia-se em dados comportamentais, enquanto a neurociência apoia-se em diversas formas de dados de outra natureza (químicos, elétricos, entre outros), tornando problemática a forma como esses dados podem ser aplicados a teorias baseadas em comportamento - por exemplo, descobre-se que o sulco intraparietal contribui para o sentido de número - mas e daí? Como isso pode contribuir para a educação? Portanto, o autor conclui que os educadores podem esperar que a neurociência não seja prescritiva, abstendo-se de pronunciar-se sobre objetivos educacionais incompatíveis com a análise neurocientífica e com aquilo que está além do nível individual. Fora isso, a neurociência poderá ser útil em um nível de análise mais detalhado (como por exemplo como as pessoas aprendem), mas tais dados apenas poderão ser úteis no contexto de uma teoria de base comportamental bem desenvolvida, defende Willingham (2009). De qualquer forma, não fica claro o que seria uma "teoria de base comportamental bem desenvolvida", como sugere Willingham (2009). Estaria o autor se referindo a algum tipo de correspondência entre uma dada função cerebral e um comportamento? Caso seja isso, tal visão não parece se descolar de um certo determinismo biológico pouco compatível com uma visão histórico-cultural da aprendizagem, e a explicação de Willingham (2009) recai no nível da tergiversação.

Para Guerra (2011), as neurociências são ciências naturais, que têm como objeto o funcionamento do sistema nervoso, o que diverge da finalidade da educação, voltada para a criação de condições para que a aprendizagem aconteça em uma dada situação e contexto. Para a autora, não se pode explicar a educação da mesma forma que a neurotransmissão. Guerra (2011) defende o caráter informativo da neurociência em detrimento do prescritivo em sua relação com a educação, e também sinaliza para o otimismo excessivo que tem envolvido esse debate frente às reais possibilidades de contribuição da neurociência para a educação dos pontos de vista teóricos e práticos. Guerra (2011) afirma que a neurociência não pode ser vista como uma panaceia para os problemas da educação, muito menos como proponente de uma nova pedagogia, mas pode ajudar a explicar porque alguns ambientes de aprendizagem funcionam e outros não, com base no que se sabe sobre o funcionamento cerebral. As dificuldades no processo de aprendizagem não são necessariamente explicáveis apenas pelo funcionamento cerebral - muito pelo contrário, já que a maioria dos casos explica-se por outros fatores relacionados à família, à escola e ao ambiente em que a criança vive, influenciada por fatores culturais, sociais e pelas políticas públicas de educação, acredita Guerra (2011), o que enfatiza ainda mais o caráter multidisciplinar dessa questão. Tal visão é 
interessante no sentido em que recorre a outros fatores além dos biológicos na tentativa de entender a aprendizagem. Nesse sentido, também, parece haver pouca contribuição a ser feita pela neurociência à educação além do seu papel informativo - o que tangencia de forma arriscada o papel prescritivo, caso essa informação não seja acompanhada de discussão e reflexão.

Mason (2009) defende que entre neurociência e educação a via deve ser de mão dupla, uma vez que o cérebro é apenas um dos componentes da aprendizagem, e a neurociência, ainda que relevante para a educação, não pode ser prescritiva, já que os processos biológicos interagem com os sociais, culturais e contextuais, incluindo as atitudes de professores, valores e crenças, fatores que não podem ser desconsiderados. A autora defende que a psicologia educacional pode servir como ponte entre neurociência e educação, já que seu objeto de interesse é o processo de ensino e aprendizagem como um todo.

Fischer, Goswami, Geake et al. (2010) colocam como objetivo da neurociência educacional e do movimento MBE unir a biologia com a ciência cognitiva, psicologia do desenvolvimento e educação para que as práticas educacionais possam ser mais solidamente fundamentadas na pesquisa sobre ensino e aprendizagem. Em vista disso, um dos principais investimentos é na desmistificação de crenças sobre o cérebro e genética, focando a investigação prática que amplie esse conhecimento, assim como as influências sociais e culturais sobre ensino e aprendizagem. Desta forma, é preciso romper com os padrões tradicionais de pesquisa, onde professores e alunos têm um papel passivo, negligenciando o ambiente escolar como fator de importância. Os autores assinalam ainda que na educação, diferente de outros campos, a utilização dos resultados de pesquisa tem sido pequena, com pouca articulação entre as instâncias de pesquisa e da prática educacional. Argumentam que grandes empresas como Avon e Toyota investem milhões em pesquisas, enquanto as escolas continuam a falar sobre melhorar as práticas sem coletar evidências sobre o que funciona, e marcam o campo emergente da neurociência educacional como uma oportunidade para lançar fundamentos sólidos para esta estrutura. As avaliações padronizadas da aprendizagem dos alunos, como o Pisa, por exemplo, segundo os autores, apoiam-se nesta suposta falta de base na pesquisa em educação, mas tem limitações sérias, uma vez que não avaliam os alunos em condições reais de aprendizagem. Em que pese o pragmatismo presente em tais afirmações de Fischer, Goswami, Geake et al. (2010), em que se releva que o objeto e o objetivo da educação são fundamentalmente diferentes dos de uma corporação capitalista (ou deveriam 
ser), considerar o que "funciona" em educação é algo problemático pelas razões já discutidas, mas nem por isso o tema deveria ser evitado, sob pena de certa naturalização da incomensurabilidade da educação.

Schrag (2011) argumenta que os filósofos da educação têm um papel de fundamental importância na conversa sobre neurociência. Ele argumenta que é provável que o impacto da neurociência seja substancial, embora não da forma como seus defensores imaginam. Tal impacto tem o potencial para melhorar a educação por meio de intervenções que alterem com sucesso os mecanismos neurais fundamentais da aprendizagem, mas é improvável que a neurociência afete o ensino em sala de aula de forma substancial.

Para Hung (2003), a neurociência ainda tem que fazer progressos significativos em suas pesquisa antes de a educação poder traduzir ou transformar estas descobertas em políticas em áreas como matemática e ciências. O autor aponta que os achados da neurociência parecem sugerir possíveis tendências em direção a algumas abordagens pedagógicas recentes, tais como a aprendizagem baseada em problemas e a aprendizagem através da descoberta. Hung (2003) considera ser mais produtivo apoiar as abordagens pedagógicas mais atuais, ao invés de discutir novas implicações para a prática de ensino a partir da pesquisa em neurociência. Enfatiza, neste sentido, a importância de se olhar o humano como um ser biológico e não como um computador, como era comum numa abordagem mecanicista da neurociência cognitiva, que por muito tempo dominou a concepção de cérebro. Atualmente, a visão do funcionamento em rede vem predominando, com destaque para o papel da emoção neste sistema, visão que Hung (2003) considera mais compatível com os objetivos da educação, em abordagens pedagógicas baseadas nos princípios de que a aprendizagem é impulsionada pela demanda de necessidades e do contexto sócio-cultural, de considerar a aprendizagem como um ato social e um processo complexo. Dessa forma, as práticas tradicionais devem ser repensadas e readequadas, e ao se considerar o dinamismo sistêmico do cérebro isso se torna ainda mais premente. As ideias aqui apresentadas e os pesquisadores envolvidos nessas pesquisas, em sua maioria, tem se reunido em torno de um movimento teórico conhecido como Mind, Brain and Education - MBE, discutido no próximo item. 


\subsection{A proposta do movimento Mind, Brain and Education - MBE (Mente, Cérebro e} Educação)

A emergente área de pesquisa conhecida como Mind, Brain and Education - MBE (Mente, Cérebro e Educação) tem como objetivo, segundo Fischer (2007), criar uma base sólida de pesquisas a fim de embasar as práticas em educação, através de conhecimentos que promovam mudanças no processo ensino aprendizagem. Tokuhama-Espinosa (2011) aponta como foco da MBE o estudo de como os humanos aprendem melhor, de forma a desenvolver melhores métodos de ensino. A MBE emerge do encontro entre psicologia, neurociência e educação como campos principais de conhecimento. A autora ressalta que se trata de uma disciplina acadêmica, e não um campo profissional, o que necessariamente inclui pesquisa e estudo, com padrões estabelecidos por sociedades de pesquisa, publicação com revisão por especialistas e outras características comuns às sociedades científicas. Para TokuhamaEspinosa (2011), a melhor aplicação da MBE se dá na sobreposição entre neurociência cognitiva, educação e a psicologia, a partir do que os pesquisadores devem definir os problemas a serem investigados a partir de um enfoque multidisciplinar. Esta, talvez, seja a maior dificuldade, ou seja, enxergar não aquilo em que estas disciplinas diferem, mas o que pode emergir do seu encontro.

Tokuhama-Espinosa $(2010,2011)$ realizou um trabalho de sistematização dos conhecimentos produzidos pela MBE. A partir das categorias de informação apresentadas no relatório Compreendendo o cérebro: em direção a uma nova ciência da aprendizagem, publicado pela Organização de Cooperação e Desenvolvimento Econômico - OCDE em 2002 (e no Brasil em 2003 - cf. OCDE, 2003), Tokuhama-Espinosa (2010) discute os termos e conceitos, bem como os neuromitos, relacionados na articulação entre educação e neurociência. Como fundamentação metodológica, a autora utiliza como critério de evidência científica a existência de estudos randomizados extensos, envolvendo determinadas quantidades de alunos (no mínimo 250) e/ou classes ou escolas (no mínimo 10), com verificação estatística e seguindo design de pesquisa padronizado, organizando os conceitos num contínuo de acordo com a maior ou menor presença dos fatores destacados. As categorias resultantes são: 
a. O que está bem estabelecido: conceitos essenciais que fundamentam básicos de boas práticas de ensino, reconhecidos unanimemente pelas três áreas envolvidas na MBE, ou seja, psicologia, neurociência e educação (por exemplo, a plasticidade cerebral);

b. O que é provável: conceitos e práticas que merecem atenção e tendem a ficar bem estabelecidos, mas que no momento atual carecem de unanimidade em pelo menos uma das três áreas da MBE (por exemplo, a ideia de períodos sensíveis no desenvolvimento, pesquisada apenas parcialmente com humanos);

c. O que é especulação inteligente: conceitos em que se deseja acreditar, mas que não estão embasados suficientemente em evidências científicas. Alguns desses conceitos, eventualmente, podem vir a ser bem estabelecidos após pesquisas que o comprovem, ou ainda descer à categoria de neuromitos, no caso de serem refutados pela mesma via científica (por exemplo, o papel das diferenças de gênero no funcionamento cerebral);

d. o que é uma falsa concepção popular ou um neuromito: conceitos que, apesar de atraentes do ponto de vista mercadológico e com divulgação na mídia que os torna populares, têm pouca ou nenhuma base científica, terminando por promover o desconhecimento sobre o funcionamento cerebral ou ainda o uso inescrupuloso de informações com finalidades comerciais (por exemplo, a teoria de que algumas pessoas funcionam mais com o lado direito do cérebro, e portanto manifestam as características tradicionalmente vinculadas a ele, enquanto outras pessoas funcionariam com o lado esquerdo do cérebro).

Proporcionalmente, o número de conceitos bem estabelecidos apontados pela autora é bem inferior ao de neuromitos (5 fatores bem estabelecidos para 28 neuromitos), o que evidencia as características deste campo de pesquisas.

Tendo-se já discutido os neuromitos anteriormente, pondera-se ser interessante apresentar o que é considerado como bem estabelecido na MBE por Tokuhama-Espinosa (2011):

1. Os cérebros humanos são únicos como faces: ainda que haja padrões básicos de desenvolvimento cerebral compartilhados pelo humanos, a especificidade de cada cérebro 
pode ajudar a explicar as diferenças no processo de aprendizagem, mas a autora alerta que isso não pode ser usado como uma desculpa para a inabilidade dos professores em ensinar a todos os alunos, e que a espécie humana compartilha estágios de desenvolvimento que servem de parâmetros para a aprendizagem, ainda que cada indivíduo tenha um cérebro único.

2. Os cérebros humanos não são iguais porque o contexto e as habilidades influenciam a aprendizagem: para a autora, as pessoas nasceriam com diferentes habilidades, que podem ser ampliadas ou perdidas, dependendo dos estímulos recebidos ou da falta deles.

3. O cérebro é modificado pela experiência: o cérebro, enquanto um sistema complexo e dinâmico, é constantemente alterado pela experiência. Segundo Tokuhama-Espinosa (2011), "você vai para a cama hoje à noite com um cérebro diferente do que você tinha quando acordou." (TOKUHAMA-ESPINOSA, 2011, p.33), ainda que tais mudanças sejam visíveis apenas num nível microscópico, e algumas delas podem tornar-se permanentes, evidenciando a influência da experiência na estrutura cerebral.

4. O cérebro é altamente plástico: o cérebro humano apresenta um alto grau de desenvolvimento e plasticidade ao longo da vida, ainda que haja limites a ela, principalmente na medida em que se envelhece. A aprendizagem por toda a vida é sublinhada, e a possibilidade de recuperação de lesões neurológicas adquiridas ou inatas também indica a potencial plasticidade do cérebro.

5. O cérebro conecta nova informação com as antigas. Conectar novas informações às anteriormente adquiridas facilita a aprendizagem, o que reafirma a importância da educação básica.

Tokuhama-Espinosa (2011) conclui apontando que esses cinco conceitos não são informações novas - o que é novo é a sua confirmação pela neurociência, pela psicologia e pela educação, conferindo-lhes portanto credibilidade ao embasar um currículo ou uma metodologia pedagógica, bem como é nova a sua aplicação na sala de aula. A autora considera que a teoria de Vigotski pode dar valiosas contribuições à MBE, destacando suas ideias acerca do desenvolvimento cognitivo e aprendizagem. Destaca também as 
contribuições fundamentais feitas por Luria em relação ao papel da cultura no pensamento e suas pesquisas sobre a memória. Adverte ainda a autora que os métodos comumente empregados pela educação e a organização da escola são contrários a algumas informações importantes sobre como o cérebro aprende - por exemplo, hábitos de sono e alimentação, bem como a gestão tradicional da sala de aula e métodos de ensino como a memorização e o ensino centrado no professor, portanto, aquilo conceituado por Paulo Freire como educação bancária.

Apesar dessas ideias serem interessantes e até certo ponto sedutoras, não fica clara como se dá a interlocução desses três campos - neurologia, psicologia e pedagogia - através de práticas que confirmariam sua validade e se embasam em fundamento teóricos dessas ciências. Em que se pese o esforço louvável de valorizar a potencialidade para a aprendizagem dos alunos, não fica claro através do que tais aportes teóricos chegam a se concretizar em práticas pedagógicas, a não ser por um exercício interpretativo da autora. A partir do que Tokuhama-Espinosa $(2010,2011)$ afirma, depreende-se que a articulação entre essas áreas é um tema chave, motivo pelo qual passa-se na sequência a discuti-lo de forma mais detalhada.

\subsection{Possíveis práticas de articulação}

Devonshire e Dommet (2010) referem que a neurociência é uma ciência jovem, que ainda está procurando seu lugar na colaboração com outras disciplinas, sendo a educação uma das possibilidades delineada mais fortemente a partir da década de 1960, motivada principalmente pela possível contribuição no campo das dificuldades de aprendizagem. Apesar do entusiasmo inicial, no entanto, a parceria não parece ter sido bem sucedida ainda. Para os autores, as barreiras que impedem esta aproximação são de natureza teórica, mas também mantidas por barreiras práticas, mais especificamente relacionadas ao uso de uma linguagem comum bem como uma compreensão básica da pesquisa científica, ou uma alfabetização científica. Os autores propõem um gráfico de como se daria a articulação entre o nível de pesquisa neurocientífica e aplicabilidade em educação, marcando sua proporcionalidade (Figura 4). 


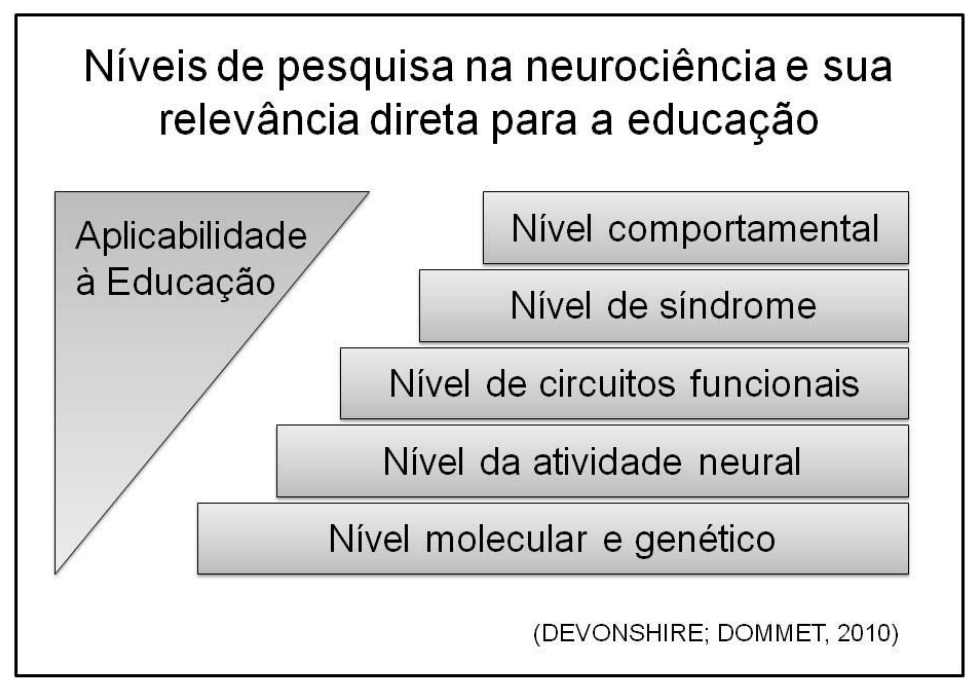

Figura 4

Para superar os problemas na articulação entre neurociência e educação identificados por Willingham (2009), ou seja, problema dos objetivos, problema vertical e problema horizontal, Devonshire e Dommet (2010) propõem formação e troca de experiências entre os campos. As soluções possíveis quanto às barreiras teóricas seriam: 1) para o problema dos objetivos, neurociência e educação devem eleger e concordar com problemas que são comuns a ambos os campos, e continuar a atuar separadamente onde isso não pode ser feito; 2) quanto ao problema vertical, deve-se considerar o quanto o nível de pesquisa se aproxima da meta padrão que perpassa os vários níveis e não é feito, investindo nos níveis mais relevantes e evitando focar na disfunção, construindo projetos de pesquisa coletivos entre educadores e neurocientistas e 3) quanto ao problema horizontal, a neurociência deve ser usada para reconhecer a diferença entre as teorias educacionais ao invés de conduzi-las. Em relação às barreiras práticas, no que se refere à linguagem comum e alfabetização científica, Devonshire e Dommet (2010) sugerem que os neurocientistas devem ser treinados na comunicação científica de forma a encorajá-los a produzir relatórios básicos de pesquisas revisadas por seus pares, ao passo que os educadores devem receber uma formação básica em neurociência e métodos de pesquisa, facilitando com que participem de pesquisas práticas. Já em relação à barreira de tempo e espaço, os autores enfatizam que tais ações devem ser previstas no horário de trabalho dos educadores, sendo vital o planejamento com antecedência para a articulação com a escola, propondo que neurocientistas e educadores 
devem encontrar-se em seus próprios territórios, a fim de compartilhar experiências de trabalho.

Samuels (2009) aponta que, historicamente, os campos epistemológicos e filosóficos da neurociência e da educação têm sido divergentes. Historicamente, têm demonstrado influir na sociedade, porém de forma separada; filosoficamente, os valores pelos quais operam muitas vezes estão em oposição, e epistemologicamente, seus campos têm contado com diferentes conceituações sobre o conhecimento. Esse tipo de discussão, observa Samuels (2009), tem sido praticamente ausente no movimento MBE. Nesse sentido, o autor sugere que essa lacuna seja enfrentada favorecendo a discussão sobre as diferenças disciplinares de forma a permitir uma melhor compreensão entre ambas e estabelecer uma comunidade colaborativa de pesquisa, bem como um enfoque transdisciplinar, ou seja, que transcende as abordagens disciplinares tradicionais de problemas complexos, concentrando-se em questões importantes e de mútuo interesse para as disciplinas.

Coch e Ansari (2009) defendem que a formação é um mecanismo crucial para o desenvolvimento de conhecimento útil na articulação entre neurociência e educação. Os autores apontam que os neurocientistas geralmente não consultam a literatura educacional para lançar suas hipóteses e conduzir estudos que possam ter uma aplicação na educação, assim como os professores geralmente não consultam a literatura neurológica para decidir como ensinar uma criança. Poucos achados da neurociência podem ser diretamente aplicados na educação, o que exigiria testes rigorosos baseados no método científico a serem desenvolvidos em na sala de aula antes que qualquer coisa pudesse ser afirmada. Assim, os autores defendem que um dos objetivos deve ser fornecer informação realista sobre essa interação: a neurociência não será uma panaceia para todos os males: professores e pesquisadores da educação sabem muito mais sobre a escola do que a maioria dos neurocientistas, e esse conhecimento é tão válido e não menos importante do que o conhecimento baseado no imageamento do cérebro. Coch e Ansari (2009) defendem formação para ambos os lados: os professores geralmente não têm formação em neurociência básica durante sua graduação, e não se trata de formá-los da mesma forma que os neurocientistas, mas oferecer uma formação básica, que os ajude a reconhecer afirmações e ofertas comerciais pouco embasadas na ciência. Da mesma forma, os neurocientistas interessados nessa articulação devem ter uma formação básica nas questões educacionais, sobre como os alunos aprendem um determinado conceito em uma sala de aula real. 
Ansari e Coch (2006) entendem que duas pontes devem ser erguidas. A primeira ponte leva ao desenvolvimento de educadores que aplicam tanto evidências cognitivas da neurociência na sua prática quanto geram novos conhecimentos educacionais e científicos relevantes através de sua colaboração com cientistas. A segunda ponte facilita o desenvolvimento de cientistas capazes de se comunicar com os educadores e gerar evidências neurocientíficas que podem ser relacionadas à educação, bem como contribuir para o conhecimento básico de ciência. Ambas as pontes levam a uma autêntica abordagem multidisciplinar, na visão dos autores. Ansari e Coch (2006) acrescentam ao debate uma série de questões provocativas, como: a ideia da articulação entre neurociência e educação poderá ir além da noção limitada apenas à aplicação na sala de aula? O campo pode se expandir além dos alunos, incluindo investigações sobre os professores e as mudanças em seus cérebros? As agências de financiamento seriam flexíveis o bastante para subsidiar pesquisas de caráter interdisciplinar entre neurociência e educação? Como os limites institucionais e estruturais do trabalho de professores e neurocientistas poderão ser superados para a construção dessas pontes? As políticas públicas de educação e de ciência podem assessorar este processo, ao invés de focarem unicamente o produto final? Como as futuras discussões sobre as bases metodológicas e conceituais de uma ciência da aprendizagem refinam e redefinem o que esta ciência pode ser e como pode atender aos elementos relevantes desta área? São boas questões para refletir, e bastante instigantes, mas aparentemente estão em um ponto muito mais adiantado da discussão, uma vez que os pesquisadores da área, de forma geral, ainda não conseguiram ir além de respostas incipientes, sem maiores experiências de articulação cuja reflexão sobre elas possa servir para alimentar essas questões cruciais.

Willingham e Lloyd (2007) apontam que apesar de muitos artigos discutirem a relação entre neurociência e educação em um nível teórico, pouco ou nada tem sido discutido sobre como se integra de forma prática dados neurocientíficos em uma teoria comportamental que utiliza construções hipotéticas. Os autores propõem que há diversos níveis de análises para neurociência e para o comportamento, organizados hierarquicamente e sustentando diversas vertentes teóricas. Segundo os autores, a educação e a cognição operam em diferentes níveis de análise comportamental, e os pesquisadores educacionais estão mais interessados em comportamentos que se relacionam com os resultados educacionais, como questões envolvendo leitura, resolução de problemas e assim por diante, interessando-se por construções cognitivas como memória ou atenção apenas na medida em que elucidam 
questões educacionais. Neste sentido, os autores descrevem quatro técnicas para uma possível articulação entre neurociência e educação para os pesquisadores: (a) observação direta das construções hipotéticas no cérebro, (b) validação de hipótese teóricas através de imagens do cérebro, (c) uso da arquitetura neural para inferir uma arquitetura de comportamento e (d) uso do conhecimento bem desenvolvido sobre o cérebro para selecionar entre teorias comportamentais concorrentes. Tais técnicas, segundo os autores, têm sido usadas para informar a pesquisa e a teoria, contudo, entendem que não são aplicáveis a todos os problemas de pesquisa educacional, mas são apropriadas para comportamentos relativamente de nível comportamental simples (por exemplo, leitura), em vez de comportamentos de nível comportamental complexo (por exemplo, gestão de sala de aula). Apontam o estudo da dislexia como um exemplo do emprego destas técnicas de forma bem sucedida, e apontam como um dos fatores para esse resultado o fato dos pesquisadores em educação já terem desenvolvido complexas teorias sobre a leitura e a dislexia baseadas no comportamento, o que norteou a interpretação dos dados neurocientíficos. Por exemplo, algumas teorias de leitura previram a potencial importância da decodificação fonológica, por isso, quando as partes do cérebro associadas à fonologia foram implicadas na dislexia, houve uma interpretação pronta. Os autores argumentam que seria proveitoso para os pesquisadores educacionais aproveitar os métodos desenvolvidos em neurociência cognitiva, o que possibilitaria uma aplicação mais frutífera dos dados obtidos pelas pesquisas neurocientíficas para as questões educacionais em que há pesquisa acumulada em bases comportamentais.

Em relação a experiências concretas de trabalho multidisciplinar envolvendo neurocientistas e educadores, Dommett et al. (2009) relatam um projeto bem sucedido de colaboração entre educadores e neurocientistas, consistindo em uma série de seminários sobre temas escolhidos por ambas as partes, como atenção, memória, emoção e desordens do desenvolvimento. O objetivo principal foi criar um diálogo entre os dois grupos. O projeto foi oferecido por um grupo de neurocientistas para um grupo de vinte professores de uma escola, que participava mensalmente de um seminário com cerca de noventa minutos, seguido por uma sessão de perguntas e respostas focada na relação que os assuntos debatidos poderiam ter na sala de aula. Os pesquisadores solicitaram que os professores anotassem suas reflexões entre as palestras em um diário, e estas podiam ser compartilhadas com o grupo a cada encontro. No final do trabalho, os autores relatam uma avaliação positiva por parte dos professores, cuja maioria considerou que informação foi apresentada de forma acessível e que 
resultou em mudanças em sua prática escolar, aprovando receber informações sobre como o cérebro funciona e desfazer os neuromitos. Após o trabalho, que durou seis meses, um grupo de pesquisadores permaneceu acompanhando os professores por mais nove meses, discutindo como poderiam usar a informação dos encontros em sua prática, e os professores também repassaram informações a seus alunos sobre o cérebro. Os autores reconhecem que esta experiência é bastante específica, envolvendo um grupo pequeno de participantes (que também faziam parte de um grupo selecionado de professores com boas práticas educacionais, segundo o sistema de avaliação do Reino Unido, onde a pesquisa foi realizada) e avaliam que esse tipo de trabalho não teria sentido na formação inicial do professor, pois é importante que o professor tenha experiência para uma participação mais reflexiva. Aliás, a reflexão sobre a discussão parece ter sido o principal fator de sucesso, uma vez que o grupo de educadores não parece ter sido tratado como um mero repositório de informações técnicas.

\subsection{Afinal, a neurociência contribui ou não para a educação?}

Em que pesem os argumentos diversos sobre como a neurociência poderia contribuir para a educação, uma coisa não foi ainda discutida radicalmente pelos pesquisadores, e pode ser resumida na questão: se há tanta controvérsia e fragilidade neste campo, pode-se pensar se há de fato alguma contribuição da neurociência para a educação. Afinal, não há nada de mais consistente do que já é conhecido pelos educadores através da experiência educacional acumulada. A questão que se coloca é: vale a pena correr o risco de tentar articular conhecimentos que são tão estanques, indo pouco além da constatação de que o cérebro é o principal órgão envolvido na aprendizagem e nos processos cognitivos de caráter escolar? De fato, como Schrag (2011) assinala, a neurociência não pode ajudar o professor a entender porque um aluno sabe multiplicar por 10 e não por 100, por exemplo, por mais potencialidades que o encontro entre neurociência e educação possa prometer. É muito difícil imaginar como a neurociência poderia influenciar as decisões ou práticas educacionais para aumentar a eficácia educacional, paradoxalmente às crescentes descobertas sobre memória e aprendizagem, o que gera uma situação desconcertante.

Observe-se, por exemplo, a questão da aprendizagem social, comentada por Schrag (2011), a partir da afirmação de Goswami (2008) de que a neurociência vem indicando 
este funcionamento social do cérebro, como já havia feito Vigotski, segundo o qual "aprender com os outros é geralmente mais eficaz do que aprender sozinho" (apud GOSWAMI, 2008, p.37). Schrag (2011) ironiza tal colocação, afirmando entender que nenhum educador afirmaria que o melhor seria aprender sozinho. Afinal, no que isso contribui? Seria a melhor forma de aprendizagem o ensino individual intercalado com brincadeiras, ou a concentração em salas com cerca de trinta alunos? A neurociência não esclarece. Conforme Schrag (2011, p.224):

Seja como for, note-se que Vigotski não precisou de imagens do cérebro, nem
neurociência, para chegar a suas conclusões. Pergunto-me, além disso, se o
entendimento atual do cérebro social poderia levar a uma conclusão bem diferente
como um resultado plausível: não que aprender sozinho é mais eficiente, mas que os
professores são mais eficientes quando há menos crianças ao redor. O cérebro
evoluiu muito antes de existirem livros, escolas e salas de aula.

A crítica de Schrag (2011) à articulação da neurociência e educação, através da discussão que faz do artigo de Goswami (2008), fundamentalmente questiona se não se trata apenas de uma nova roupagem para princípios já conhecidos, acumulados de forma intuitiva por professores experientes, para informações do tipo "as emoções afetam a aprendizagem" ou "a aprendizagem ocorre por toda a vida". Do ponto de vista dos professores, saber quais as estruturas cerebrais envolvidas na aprendizagem da leitura não acrescenta nada às estratégias para ensinar uma criança a ler, segundo o autor.

Considere-se, por exemplo, as dificuldades no processo de alfabetização. Num grupo de alunos com dificuldades com o qual se realiza uma dada intervenção, parte supera a dificuldade, sendo ajudado pela estratégia empregada, e parte permanece com a mesma questão. $\mathrm{O}$ escaneamento cerebral do grupo que não foi ajudado revela que tem uma dada falha numa estrutura "x" do cérebro. Schrag (2011) argumenta que tal informação aumenta o nosso conhecimento sobre os problemas de leitura, mas não ajuda em nada os professores a intervir de forma a levar seus alunos a superarem essa dificuldade. Se todos os alunos tiverem seus cérebros escaneados e forem identificados aqueles com problemas na "estrutura $\mathrm{x}$ " poder-se-ia saber quais terão dificuldades. Ora, mas isso também não poderia ser obtido com uma simples sondagem do professor? Schrag (2011) retoma uma fala do cético Bruer já apresentado, segundo a qual qualquer evidência a favor ou contra a eficácia de uma dada abordagem educacional pode ser encontrada em livros atuais sobre psicologia educacional, e nenhuma delas decorre de pesquisa do cérebro. 
Schrag (2011) se pergunta se não seria necessário que os filósofos da educação contivessem o entusiasmo dos neurocientistas que acreditam estar em busca do santo graal para a mudança da educação, e afirma claramente que não. Justifica dizendo que os que estão encabeçando essa pesquisa sabem das suas limitações, bem como da propensão dos discípulos menos qualificados para nos enganar, como ocorre com os neuromitos. Com isso, Schrag (2011) discute o papel que os filósofos da educação como ele podem ter diante da questão, utilizando como argumento a discussão feita por Davis (2008) a respeito dos efeitos de diagnósticos como a dislexia e o TDA-H, que não são ajudados em termos de intervenção educacional pelo crescente conhecimento da neurociência, e resultando em implicações éticas preocupantes, como a isenção de responsabilidade dos educadores diante do comportamento medicalizado dos alunos, o que leva Schrag (2011) a reiterar a afirmação de Davis (2008) de que uma taxonomia humana dos problemas no processo ensino aprendizagem não pode ser baseada exclusivamente em fatores neurológicos, ainda que reconheça sua influência nestas situações. Schrag (2011) ressalta que as colocações de Davis (2008) são aprofundadas e matizadas, como cabe a um filósofo da educação nesta discussão, discutindo o próprio conceito de classificação aplicada ao humano.

Schrag (2011) comenta a posição de Howard-Jones (2008) em relação à pouca utilidade que a neurociência possa ter para os educadores, quando afirma que o preço a pagar é alto, ou seja, desconsiderar os avanços que têm sido feitos na questão do cérebro. HowardJones (2008) reconhece que os pesquisadores acabam por privilegiar o impacto dos processos cerebrais sobre o comportamento manifesto, ignorando que o comportamento pode alterar o cérebro como parte de um processo dialético. Howard-Jones (2008) alinha-se, portanto, com uma visão mais cautelosa sobre a articulação entre neurociência e educação, com o que Schrag (2011) novamente se pergunta o porquê de tanto entusiasmo. Conclui afirmando que os dados da neurociência podem informar as políticas escolares (como no caso das aulas no período da tarde para adolescentes, cujas necessidades de sono são maiores), e é mais provável que a neurociência possa contribuir para melhorar a educação com intervenções no nível do cérebro em si, através de tratamentos e medicamentos, num nível de atuação mais individual e molecular do que na educação como tarefa social, contribuindo para reduzir os déficits no nível micro e daí melhorando o desempenho geral no nível macro. Ou seja, Schrag (2011) acredita que os avanços científicos da neurociência certamente trarão benefícios à educação, mas de uma forma diferente da que os líderes do movimento MBE acreditam, não 
afetando a sala de aula em si, mas possibilitando que as crianças fiquem mais preparadas para aprender. Infelizmente, Schrag (2011) não chega a discutir as implicações éticas do que está propondo, como por exemplo o acesso a medicamentos que supostamente incrementam a memória, a cognição e a aprendizagem como sendo restrito à parcela da população que possa arcar com seus custos. Desta maneira, parece que Schrag (2011) chega ao mesmo lugar que a concepção medicalizante e biologizante, mas pelo caminho inverso. Ou seja: ao propor a exclusão da neurociência na relação com a escola como instituição e limitá-la à esfera celular e terapêutica, voltada para a criação de indivíduos supostamente mais preparados, Schrag (2011) parece assumir que essa formação poderia se dar em detrimento dos contextos sociais dos quais os alunos participam, com destaque para o ambiente escolar.

\subsection{Um olhar da psicologia histórico-cultural sobre a questão}

Tendo até agora apresentado as principais implicações da discussão sobre a articulação entre neurociência e educação, passa-se a enfocar as mesmas em confronto com os pressupostos da psicologia histórico-cultural.

A relação entre ambiente e indivíduo, ou entre contexto sócio-cultural e genética (nurture e nature), no processo de desenvolvimento, é um dos temas fundamentais da psicologia histórico cultural, uma vez que o próprio entendimento que Vigotski conferiu ao conceito de desenvolvimento cultural implica a relação indissociável entre desenvolvimento orgânico e desenvolvimento psicológico (VYGOTSKI, 1929/2008). Smith (1998, p.116) defende que "os seres humanos de todas as culturas possuem o mesmo potencial biológico para desenvolver suas habilidades de sobrevivência em ambientes físicos e culturais diversos", com o que não está desconsiderando as variações individuais em relação à diversidade cultural, mas destacando que as pesquisas têm demonstrado existir alguns traços biológicos característicos da espécie humana que norteiam seu desenvolvimento. Contudo, reitera que este desenvolvimento ocorre em estreita dependência com os significados construídos em cada cultura, com o que Smith (1998) propõe que o desenvolvimento humano é mais influenciado pelas experiências culturais em sua diversidade do que pela homogeneidade dos aspectos biológicos do mesmo processo que caracteriza a espécie humana, e cita a argumentação defendida por Edelman (1987, apud SMITH, 1998) em relação 
à natureza variável do sistema nervoso, que não é configurado a priori, mas sim de acordo com as experiências do ambiente. Tal desenvolvimento, como proposto por Vigotski, é mediado por signos na construção de significados, tarefa embasada culturalmente e que se dá através da negociação entre indivíduos desta mesma cultura.

Yasnitsky (2009) também entende que a junção entre a investigação das práticas científicas sob uma abordagem histórico-cultural com a pesquisa filosoficamente orientada sobre teoria e método em psicologia é particularmente importante no momento atual, no qual se observa o crescimento do interesse em associar a pesquisa sobre cérebro e a educação, temas que aparecem de forma altamente integrada na obra de Vigotski, Luria e outros pesquisadores da psicologia histórico-cultural.

Apresenta-se aqui a leitura feita pelo filósofo David Bakhurst (2008) sobre a relação cérebro e educação em seu texto integrante da excelente edição especial do Journal of Philosophy of Education de 2008, coordenada por Ruth Cigman e Andrew Davis, intitulada New Philosophies of Learning e publicada em formato de livro em 2009.

Neste texto, Bakhurst (2008) resgata o filósofo soviético Evald Ilyenkov e seus escritos publicados entre 1960-1970 sobre o problema mente-corpo. Bakhurst (2008) conceitua como cerebrismo (brainism) a visão de que a vida mental de um indivíduo é formada por processos e eventos em seu cérebro, a quem os atributos psicológicos são imputados, ponderando que tal ponto de vista era combatido por Ilyenkov, para quem não é o cérebro que pensa, e sim um ser humano com o concurso de seu cérebro. Ilyenkov rejeita o cerebrismo em favor do que chama de personalismo, a visão de que os atributos psicológicos são propriedades de pessoas e não de cérebros. Para ele, o sujeito psicológico é a pessoa, e não seu cérebro, e mais do que isso, é a pessoa numa unidade com natureza e sociedade. No entendimento de Wolfe (2011), sob uma interpretação materialista tal perspectiva seria fenomenológica, no sentido em que enfatizaria a atividade da consciência em detrimento do cérebro enquanto órgão concreto ${ }^{58}$. No entanto, quando Wolfe (2011) afirma que o cérebro

\footnotetext{
${ }^{58}$ Nesse sentido, retome-se a definição de Merleau-Ponty colocada nas primeiras páginas de A fenomenologia da percepção: "Trata-se de descrever, não de explicar nem de analisar. Essa primeira ordem que Husserl dava à fenomenologia iniciante de ser uma 'psicologia descritiva' ou de retornar 'às coisas mesmas' é antes de tudo a desaprovação da ciência. Eu não sou o resultado ou o entrecruzamento de múltiplas causalidades que determinam meu corpo ou meu 'psiquismo', eu não posso pensar-me como uma parte do mundo, como o simples objeto da biologia, da psicologia e da sociologia, nem fechar sobre mim o universo da ciência. Tudo aquilo que sei do mundo, mesmo por ciência, eu o sei a partir de uma visão minha ou de uma experiência do mundo sem a qual os símbolos da ciência não poderiam dizer nada. Todo o universo da ciência é
} 
não pode ser abstraído do universo de relações sociais converge com a assertiva de Ilienkov, para quem a vida mental não se resume a eventos internos, mas reside no engajamento do humano com o mundo possibilitado por sermos seres sociais. Ilyenkov, segundo Bakhurst (2008), adotava um ponto de vista histórico cultural sobre o cérebro e a mente destacado dos filósofos da sua geração, pois relacionou as controvérsias filosóficas sobre cérebro e mente às questões sociais e políticas. Portanto, Bakhurst (2008) entende que o personalismo não é uma forma de dualismo cartesiano. Ilyenkov, ao afirmar que os estados mentais não estão no cérebro, não quer dizer que eles residam em alguma substancia imaterial ou um órgão imaterial do pensamento, e sim que os estados mentais são estados das pessoas como um todo - e pessoas são seres materiais, humanos, que habitam o mundo natural. Assim, seria incoerente utilizar predicados psicológicos para qualquer outra coisa que não seja pessoas. Bakhurst (2008) conclui que estabelecer uma correlação é algo diferente de afirmar algum tipo de identidade. $\mathrm{O}$ funcionamento do cérebro permite a mentalidade, mas não é constitutivo dela.

Uma das preocupações de Ilyenkov era a influência do cerebrismo na educação, pois temia que essa visão encorajasse ideias inatistas sobre o potencial de aprendizagem dos alunos, a partir da justificativa de que a capacidade de aprender seria em parte determinada geneticamente, podendo beneficiar-se ou não da escola em função disso, e assim gerando a culpabilização do aluno pelo fracasso da aprendizagem devido a suas supostamente inatas habilidades ou à falta delas, quando o verdadeiro culpado seria o sistema de ensino, em sua opinião. Uma ciência do cérebro do futuro poderia encaminhar os estudantes de acordo com suas habilidades, o que, na visão de Ilyenkov, reafirma a divisão do trabalho com base em supostas características essenciais do indivíduo, o que afronta o compromisso marxista contra esse tipo de rotulação, e defendendo, na direção oposta, que a capacidade para aprender é ilimitada. Para Ilyenkov, se algo dá errado no processo de aprendizagem, deve-se olhar para as causas sociais ao invés das biológicas. Esta visão está de acordo com o que ensinou Vigotski (1926, p.284), para quem

construído sobre o mundo vivido, e se queremos pensar a própria ciência com rigor, apreciar exatamente seu sentido e seu alcance, precisamos primeiramente despertar essa experiência do mundo da qual ela é a expressão segunda" (MERLEAUPONTY, 1999, p.4). 
uma educação realizável em termos ideais só é possível com base em um ambiente social devidamente orientado e, consequentemente as questões radicais da educação não podem ser resolvidas senão depois de resolvida a questão social em toda a sua plenitude. Mas daí decorre também outra conclusão: o material humano possui uma infinita plasticidade em um meio social corretamente organizado. Tudo no homem pode ser educado e reeducado sob uma correspondente interferência social. Neste caso, o próprio indivíduo não deve ser entendido como forma acabada mas como uma permanente e fluente forma dinâmica de interação entre o organismo e o meio.

Ilyenkov enfrentou oposição à ideia de que o cerebrismo seria incompatível com o marxismo, pois numa relação direta, marxistas são materialistas e portanto devem admitir que os processos mentais são processos cerebrais. Bakhurst (2008) adverte que seria absurdo se os filósofos desconsiderassem a pesquisa empírica, mas Ilyenkov insistia que a substância da mente é sempre a vida-atividade da pessoa, sendo o cérebro e sua estrutura inata apenas seu substrato biológico, ao qual não se deve limitar a pesquisa, sob pena de ser o mesmo que estudar a composição física do dinheiro (papel, metal) para entender como o conceito de valor, como apontava Ilyenkov. Nesse sentido, Bakhurst (2008) recorre ao argumento de Bennett e Hacker (respectivamente neurocientista e filósofo), para quem, na esteira de Wittgenstein, os atributos psicológicos não podem ficar restritos ao cérebro, portanto não faz sentido dizer que o cérebro pensa ou decide, pois isso é feito por pessoas e não por cérebros. Em resposta, os filósofos materialistas Bennett e Searle argumentam que a consciência é um fenômeno biológico causado pelo cérebro e que os estados mentais existem nele. Trata-se, portanto, de uma polêmica que está longe de terminar.

Bakhurst (2008) imagina que Ilyenkov acharia tristemente familiar a literatura crescente sobre a relevância da neurociência para o ensino e a aprendizagem. Utilizando como exemplo o texto de Blakemore e Frith (2005), Bakhurst (2008) aponta como contraditório o fato das autoras serem entusiastas com a articulação entre neurociência e educação, especulando que "no futuro, haverá todos os tipos de formas novas e radicalmente diferentes para aumentar o potencial do cérebro para aprender" (ibidem, p.167), ao mesmo tempo em que são bastante prudentes ao discutir formas de ensino embasadas cientificamente pela neurociência. Ainda assim, Bakhurst (2008) ressalta que o texto reflete o entusiasmo de uma ciência jovem, discutindo descobertas que poderão vir a ter consequências sobre as práticas educacionais no futuro, principalmente no que se refere à pesquisa sobre as dificuldades no processo ensino aprendizagem. A prudência das autoras, no entanto, não é unanimidade entre os pesquisadores desta seara. Bakhurst (2008) cita Bruer como um crítico da brain-based 
education desde seus primórdios, apontando sua afirmação de que "a literatura de educação baseada no cérebro não é produzida por neurocientistas, mas por educadores e consultores educacionais, embora eles se proponham a fundamentar suas conclusões e recomendações sobre a ciência" (BRUER apud BAKHURST, 2008, p.419). Bakhurst (2008) acredita que Ilyenkov certamente teria aplaudido Bruer, mas iria mais longe do que ele, uma vez que Bruer não questiona radicalmente a relevância dos estudos do cérebro para a educação, e sim critica a falta de evidências científicas envolvendo essa discussão. Ilyenkov provavelmente também criticaria o trabalho de Blakemore e Frith, segundo Bakhurst (2008), pois em afirmações como "o cérebro evoluiu para educar e ser educado" as autoras promovem a visão de que o verdadeiro foco da educação é o cérebro, e não as pessoas.

Os personalistas, segundo Bakhurst (2008), entendem que o que se pode observar no cérebro concreto reduz-se a correlatos de processos mentais, e as imagens do cérebro a que se tem acesso atualmente não permitem observar os processos mentais em si mesmos. Para o personalista, os dados mentais têm uma dimensão qualitativa subjetiva e fenomenológica, ou seja, “embora seja possível observar o que está acontecendo no cérebro de uma pessoa quando ela vê uma bandeira vermelha, não podemos observar como é para ela vê-la" (ibidem, p.422). No entanto, para um personalista essa conclusão soaria diferente, pois entende a mente humana como uma unidade psicológica. Os estados mentais de uma pessoa não são objetos dispersos, mas têm um lugar em uma rede de estados mentais, formando um sistema unificado, em relação ao qual toda nova informação é avaliada. Só é possível adotar uma nova crença se for compatível com o que já se acredita, e se é plausível à luz das concepções existentes, explica Bakhurst (2008). Os estados mentais são unificados porque são de uma pessoa em particular, que através deles se expressa para o mundo. Portanto, "para compreender a unidade de uma vida mental temos de pensar na pessoa, ao invés de qualquer de suas partes, como sujeito legítimo de atribuição psicológica, pois é a pessoa que tem uma orientação para o manifesto do mundo em ação, não seu cérebro" (ibidem, p.422).

Para Ilyenkov, a criança habita um mundo social não só por interagir constantemente com outras pessoas (das quais depende para sua própria sobrevivência), mas porque seu mundo está cheio de objetos criados por seres humanos para fins humanos. $\mathrm{O}$ mundo é humanizado por nossa atividade, habitado por objetos criados que são personificações de significado e propósito. A forma física de um artefato incorpora as finalidades para as quais ele é usado, portanto, ao aprender a manuseá-lo, a criança responde 
a este objeto significativo, adaptando-se à esta forma, conforme aponta Bakhurst (2008). A vida da mente é vivida no espaço social, mediada por formas de pensamento e de investigação que são essencialmente sustentadas por práticas sociais.

Ilyenkov aponta que o traço distintivo do pensamento humano está em sua universalidade, criatividade e imprevisibilidade. Para ele, a mente humana é universal na medida em que é, em princípio, aberta a qualquer objeto. A mente humana sempre transcende seus próprios limites, não apenas aplicando técnicas antigas a novos problemas, mas propondo problemas precisamente para desenvolver métodos para resolvê-los, um processo que, por sua vez, descobre novas questões, a criação de novos espaços-problema exigindo mais inovação e assim por diante. Para entender esse processo dialético, não se pode representar a mente como determinada por condições antecedentes, e sim pela lógica do objeto que confronta, segundo Ilyenkov. Para evoluir, a mente humana deve ser capaz de transcender as regras e princípios que anteriormente regeram seu funcionamento. Ilyenkov conclui que se o cérebro é uma coisa física operando de acordo com leis físicas, suas atividades não podem ser tudo o que existe para a vida da mente. A máquina, mesmo uma máquina biológica incrivelmente complexa, só pode fazer aquilo para o que foi programada. Nenhuma máquina pode ser verdadeiramente universal da mesma forma que a mente humana é universal.

No que se refere aos ditos problemas no processo de ensino aprendizagem, Bakhurst (2008) nos oferece algumas contribuições interessantes de Ilyenkov. Para ele, quando a aprendizagem ocorre sem problemas, a criança é vista a partir da perspectiva da racionalidade, como um agente racional gradualmente assumindo o comando de algum objeto, fazendo inferências certas, envolvendo-se em determinadas práticas e assim por diante. Se a criança encontra obstáculos para a aprendizagem, inicialmente busca-se resolver o problema com explicações racionais, por exemplo, inferindo que faltando alguma informação. Contudo, se chegar-se à conclusão que tais considerações racionais não podem explicar a dificuldade da criança, entende-se que seu problema é de outra ordem, e passa-se a uma explicação causal em detrimento de uma racional, decorrendo daí o apelo às classificações de dificuldades de aprendizagem. Tais explicações causais procuram mecanismos subjacentes, e logo se conclui que poderia ser uma questão do funcionamento do cérebro. Ilyenkov adverte que, quando se adota a perspectiva causal sobre os problemas da criança, deixa-se de vê-la como um agente racional neste aspecto, isentando-a de qualquer 
responsabilidade ou culpa por suas falhas. Ilyenkov questiona provocativamente por que se deve concluir que a ciência do cérebro só é boa para explicar os obstáculos para a aprendizagem, e se esta ciência não poderia esclarecer porque alguém é especialmente bom em algum campo. Por que se deve supor que o único fato relevante na pesquisa neurofisiológica é o funcionamento subnormal do cérebro? Ilyenkov convidava a supor que a ciência do cérebro poderia da mesma forma explicar o desempenho excepcional. De fato, a ideia de que a neurociência pode apenas contribuir para a compreensão do déficit parecer ser muito mais um resultado da recorrência da escola às explicações neurológicas para as perturbações no processo de escolarização do que uma opção da neurociência propriamente dita. Parece ser mais sedutor acreditar nos comprometimentos genéticos da memória do que na plasticidade cerebral pós-lesões, já que a primeira opção explica de forma restrita ao aluno, enquanto no segundo caso admite-se que, diante de uma correta intervenção do meio, o cérebro poderia recuperar a capacidade perdida.

A partir dessas colocações, fica claro que Ilyenkov acreditava que apenas os fatores sociais são relevantes para a explicação das habilidades, sem maiores explicações do motivo pelo qual isso deveria ser assim. Bakhurst (2008) alerta que, na ausência de uma evidência empírica real, essa suposição pode ser baseada apenas em pensamento positivo, na esperança de que fatores sociais podem ser controlados e melhorados de uma forma como os fatores biológicos não podem ser. É claro, há tanta razão para evitar o determinismo biológico grosseiro quanto há para evitar um ambientalismo a priori. É fundamental reconhecer que, embora a aquisição e o exercício de uma habilidade (por exemplo, para cantar uma escala maior) são ativados por fatores biológicos, alguns dos quais podem ser inatos, a capacidade em si é possuída pela pessoa, não pelo seu cérebro. Além disso, uma habilidade só é inteligível à luz das considerações sócio-históricas, e sua aquisição deve ser vista como a apropriação de uma prática social.

Bakhurst (2008) conclui que mesmo que o personalismo seja verdadeiro e os atributos psicológicos não possam ser legitimamente atribuídos ao cérebro, a neurociência permanece relevante para a compreensão dos processos cerebrais que permitem e facilitam a nossa vida mental. Não há uma razão a priori para declarar a ciência do cérebro como sendo irrelevante para questões educacionais, ou relevante apenas nos casos de "déficits". O que é crítico, porém, é que o interesse no cérebro não deve distrair a atenção do fato de que a educação é um esforço de comunicação, não um problema de engenharia. Educação não se 
resume à obtenção de informações da cabeça dos alunos ou de implantação de habilidades neles. O autor insiste que nunca se deve perder de vista a essência da educação é o encontro de mentes no encontro com uma disciplina.

Bakhurst (2008) admite que essas reflexões podem parecer antiquadas, mas revela seu espanto com a ingenuidade de estudiosos que ponderam a possibilidade de "tomar uma pílula para aprender". Se é vetado para os atletas usar drogas para melhorar seu desempenho, por que se deveria acolher formas farmacêuticas de melhorar a aprendizagem? Se se impede estudantes de levar computadores em exames nos quais eles tenham baixado textos, deve-se olhar mais favoravelmente sobre a perspectiva de que seu material possa ser baixado diretamente dentro de seus cérebros? Se tais questões são fantasiosas, levantam no entanto questões éticas que forçam a confrontar a questão do que a educação é e do que deve ser.

Em conclusão, Bakhurst (2008) enfatiza que não se deve deixar o entusiasmo sobre as possibilidades de inovação científica e tecnológica distorcer a concepção de educação e dos valores que deveria encarnar, reiterando que esta foi a mensagem que Ilyenkov procurava transmitir em seus escritos sobre educação, e que, apesar de ter sido feita há muitos anos, ainda permanece atual. Diante do que aqui foi apresentado, parece prudente concordar com estas recomendações. 


\section{CONSIDERAÇÕES FINAIS: "FINIS CORONAT OPUS ${ }^{59,}$}

La mano hizo el trabajo, como el trabajo la mano. $Y$ por el trabajo y la mano la evolución de la mente y por ende el aumento del cerebro humano.

La mano pensante. (Ernesto Cardenal)

O experimento e o poema se completam. A mente, feita pelos dois, torna-se um todo.

(Jonah Lehrer)

Diante do que aqui foi apresentado e discutido, algumas considerações podem ser feitas que, mesmo de forma inconclusiva, levantam algumas possibilidades de reflexão. Nesse sentido, é importante retomar o objetivo desta pesquisa, que é analisar o conceito de cérebro na obra de Vigotski, discutindo em que medida as proposições teóricas do autor sobre a base material da consciência influenciaram os fundamentos da psicologia histórico-cultural.

Do ponto de vista da psicologia histórico-cultural, a principal conclusão a que essa reflexão conduz é acerca do caráter biológico do cérebro humano como não sendo definitivo ou geneticamente determinado, mas formado a partir da relação com o meio externo. Pôde-se observar, durante a análise e discussão da produção teórica vigotskiana sobre a temática, que Vigotski conferiu um lugar privilegiado aos mecanismos cerebrais que estão por trás dos comportamentos observáveis, ainda que não pudesse ir muito além de inferências acerca do funcionamento cerebral, dadas as limitações tecnológicas de sua época. Isso não o impediu, conforme já se afirmou aqui anteriormente, de realizar um esforço teórico a partir dessas evidências experimentais e clínicas a fim de compreender como as funções psíquicas

\footnotetext{
${ }^{59}$ Expressão em latim que significa "o fim coroa a obra”, comentário feito na revisão desta tese por Paula Lopes da Silva, a
} 
se relacionam com as funções cerebrais, de forma articulada e coerente com a concepção teórica da psicologia histórico-cultural, ou seja, não tomando de forma isolada os processos psíquicos dos neurofisiológicos. Tal questão, é importante dizer, é a questão fundamental da neurociência, conhecida como hard problem pelos filósofos da mente e que, mesmo em face dos tremendos progressos que foram feitos no conhecimento do cérebro nos últimos anos, permanece até hoje sem uma resposta definitiva.

Para Vigotski, o cérebro humano, assim como a mão humana e as ferramentas produzidas pelo homem, são responsáveis pela possibilidade do ser humano ampliar seu raio de atividade, transformando a natureza e sendo transformado pelo produto dessa transformação, processo que caracteriza seu desenvolvimento superior em relação aos outros animais. $\mathrm{O}$ autor assinala, no entanto, que não se trata de uma questão de meramente enfatizar a superioridade do cérebro humano, mas sim ressaltar que o cérebro humano é o cérebro de um ser social, e que, portanto, funciona através da formação de funções psicológicas superiores sobre as elementares, formando a base da personalidade humana e da sua interação com o meio externo, meio que é formado pela cultura humana e natureza transformada, num processo dialético que ultrapassa os limites da pele de cada um, onde biologia e cultura imbricam-se no desenvolvimento cultural.

Vigotski definiu o cérebro humano como algo além de um simples órgão, na medida em que "se distingue de todas as demais partes do organismo e está unido de maneira imediata e direta ao desenvolvimento psíquico do homem” (VIGOTSKY, 1931/2004, p.136). Isso não deve ser entendido, sob nenhuma hipótese, como se o cérebro humano tivesse algum tipo de relação não material com uma mente exterior. Longe disso. Para Vigotski, o cérebro é o substrato material da consciência, e o desenvolvimento histórico da consciência está unido fundamentalmente ao desenvolvimento do córtex encefálico, como já se teve oportunidade de ressaltar aqui anteriormente.

O funcionamento do cérebro, segundo Vigotski, fundamenta-se na atuação conjunta de suas áreas na atividade cerebral. Portanto, uma função específica, como a atenção ou a memória, genericamente falando, não se resume à atividade de uma área específica, mas resulta de uma atividade integrada entre vários centros diferenciados e relacionados 
hierarquicamente. Assim, o cérebro não funciona de forma homogênea, e tanto funções globais quanto parciais pressupõem divisão e unidade, especialização e integração, que não se excluem mas antes se interpenetram, numa relação dialética entre o conjunto e as partes do cérebro. O funcionamento do cérebro enquanto conjunto organiza-se como uma atividade integrada a partir de relações dinâmicas e hierarquicamente organizadas entre os centros cerebrais. No processo de desenvolvimento, as funções psicológicas superiores vão se formando e introduzindo mudanças nessa organização, resultando em uma nova forma de funcionamento da consciência, que vai além da inibição e estimulação da atividade nervosa reflexa. Como isso ocorre dentro de um funcionamento sistêmico, as relações corticais são afetadas e modificadas, gerando novas formas de apropriação da realidade e assim sucessivamente, também caracterizando um processo dialético. Vigotski parte dessa concepção para explicar a correlação entre as unidades funcionais e estruturais nos casos de deficiências e lesões, explicando-as de forma cronogenética, resumida na frase: "o desenvolvimento vai de baixo para cima, a decadência de cima para baixo" (VIGOTSKI, 1934/2004, p.198), conforme se discutiu aqui anteriormente.

Em relação à localização das funções cerebrais, Vigotski defende que se deve considerá-la de forma diferenciada nos animais e no homem, não sendo possível uma transposição direta dos dados obtidos pela pesquisa com animais para o cérebro humano, o que é absolutamente coerente com sua visão do desenvolvimento cultural humano. Esse pressuposto, portanto, insta a adoção de uma postura prudente em relação à grande parte dos resultados de pesquisas neurocientíficas, já que tais estudos são comumente realizados em modelos animais.

Mas talvez uma das assertivas mais interessantes, dada sua atualidade, sobre o funcionamento do cérebro, é a questão das conexões extra-cerebrais, ou seja, aquelas estabelecidas inicialmente através da atividade externa e social, e depois interiorizadas e transformadas em atividade interna, relacionando-se com a teoria da origem social das funções psicológicas superiores e assinalando a possibilidade de recuperar funções lesionadas através da compensação ao direcioná-las para fora, transformando em atividade externa o que antes competia a uma função interna. Alguns exemplos aqui apresentados foram o sistema Braille, permitindo às pessoas com deficiência visual a aquisição da leitura e escrita, assim como o uso do Google enquanto estratégia cognitiva para recuperação de memórias armazenadas fora do cérebro, na internet (SPARROW; LIU; WEGNER, 2011). 
Outra questão fundamental no pensamento de Vigotski, intrinsecamente ligada à questão do cérebro e, como já se apontou, talvez a mais importante questão da psicologia histórico-cultural, é a questão da consciência. Nos primeiros esboços desta tese, utilizei a expressão "base material da psique" para designar o cérebro da forma específica como é tratado pela psicologia histórico-cultural. No entanto, em revisões posteriores, optei pela expressão base material da consciência, como pôde ser notado. Apesar de o termo psique ser plenamente justificável do ponto de vista da obra do autor, uma vez que é extensamente utilizado por Vigotski, ponderei que tal conceito talvez soasse ligeiramente datado, não sendo um palavra cuja manutenção se justifique pelo seu papel estruturante na obra vigotskiana, como é o caso do termo defectologia ${ }^{60}$. Além disso, o termo psique é demasiadamente amplo, e não reflete de forma tão precisa o sentido da dinâmica psicológica relacionada à atividade cerebral como ocorre com o termo consciência, preferido aqui menos por ser um termo mais presente na literatura neurocientífica e mais pela sua presença fundamental na teoria vigotskiana.

Vigotski considera a consciência como o objeto por excelência da psicologia histórico-cultural desde seus primeiros trabalhos (VIGOTSKI, 1924-1926/2004). Para ele, a consciência é um produto da evolução do cérebro (VIGOTSKI, 1925/2004), argumento que deixa clara sua concepção monista e materialista da psicologia humana. Nesse sentido, é provável que Vigotski aprovasse as investigações neurocientíficas atuais, uma vez que a discussão de uma suposta existência da consciência fora do cérebro, como é característico de uma visão idealista, desapareceu das pesquisas publicadas na área, ocupando um flanco de resistência nas provocações filosóficas como as realizadas pelo filósofo da mente australiano David Chalmers. No entanto, é provável que Vigotski visse com desconfiança as tentativas de articular as conclusões de pesquisas neurocientíficas realizadas em nível molecular com o comportamento humano, em que se desconsidera a perspectiva de uma interação com o meio histórico e cultural. Nesse sentido, também se recupera aqui o conceito vigotskiano de Homo

\footnotetext{
${ }^{60}$ Confronte-se a justificativa na recente tradução feita por Denise Regina Sales, Marta Kohl de Oliveira e Priscila Nascimento Marques do texto A defectologia e o estudo do desenvolvimento e da educação da criança anormal (VIGOTSKI, 2011).
} 
duplex, segundo o qual a consciência humana decorre de experiências sociais internalizadas, que foram inicialmente vividas como uma relação entre duas pessoas, e na medida em que são internalizadas passam a ser vividas como uma relação entre centros corticais, como nos processos de evocação da memória. Assim, para Vigotski, a origem da consciência é social (VIGOTSKI, 1924-1926/2004).

Não é demais ressaltar que a obra de Vigotski não deve ser utilizada em defesa do reducionismo biológico. Como apontou Teixeira (2005), Vigotski recusou o esquema estímulo-resposta justamente por caracterizar o psiquismo como algo estático ou mero conjunto de respostas aos estímulos ambientais, pois entendia que o ser humano não apenas reage ao ambiente externo, mas também ao meio criado pela sua própria atividade. Assim, o conceito de reflexo apresentado na obra de Vigotski não é meramente um conceito biológico, e sim se relaciona com a ideia de que a realidade é anterior à consciência, conforme postula o materialismo histórico-dialético. A consciência não espelha a realidade, mas a recria, num processo que implica a ação do indivíduo no seu meio, que não é um meio "natural", mas um meio criado pelo homem, um meio cultural. Ao recriar essa realidade socialmente construída, o psiquismo também se torna social. Como aponta Garai (1996), a consciência é tanto um produto do funcionamento do cérebro individual quanto das estruturas culturais interindividuais.

Em relação às possíveis implicações para a educação das ideias aqui apresentadas e discutidas, penso que a mais importante é a que se relaciona com a biologização da escola, ou seja, a recorrência a explicações de base biológica e centradas no aluno para a explicação do fracasso da escola, desconsiderando as bases sociais e históricas de um fenômeno complexo como a escolarização. Como assinala Patto (1999), a visão ideológica profundamente enraizada numa concepção de classe que separa os indivíduos de acordo com sua posição econômica na sociedade capitalista já se expressou de diversas formas nas tentativas de classificar os alunos provenientes das camadas populares. É interessante retomar aqui alguns pontos dessa história, para enfatizar essa consideração.

Essa diferenciação de classes está imbricada com a formação histórica da sociedade ocidental, como demonstra Patto (ibidem), tendo atravessado diversas fases. As teorias racistas empenharam-se em provar a superioridade dos nobres e seus sucessores burgueses sobre as classes desfavorecidas economicamente: "no nível das ideias, a passagem sem traumas da igualdade formal para a desigualdade social real inerente ao modo de 
produção capitalista dá-se pela tradução das desigualdades sociais em desigualdades raciais, pessoais ou culturais" (PATTO, 1999, p.50, grifos da autora). Nesse processo, os cientistas exerceram um papel fundamental, com iniciativas como as sociedades frenológicas na Inglaterra e França no início do século dezenove, bem como as discussões sobre inatismo e caráter nacional, assinala Patto (ibidem). Após a revolução burguesa, as teorias do determinismo racial vão se fortalecendo, principalmente na França, que é o país responsável por grande parte do capital cultural herdado pela elite intelectual brasileira. Em conformidade com os ideais iluministas, que pregavam o anticlericalismo e o cientificismo, as teorias raciais foram adquirindo ares de conhecimentos objetivos sobre a realidade, produtos científicos e portanto inquestionáveis, de acordo com os ideais positivistas que também influenciaram a elite científica brasileira. Conforme Poliakov (apud PATTO, ibidem, p.52), "um cientificismo ingênuo e um racismo militante" caracterizaram o apogeu das teorias racistas. Outro cientista com ideias semelhantes foi o inglês Francis Galton (1822-1911), que procurou provar que a capacidade intelectual seria determinada hereditariamente, de acordo com a sua leitura da teoria darwinista, sendo um dos primeiros a utilizar testes psicológicos em suas pesquisas, que tinham uma orientação eugênica, como assinala Patto (ibidem).

Os testes psicológicos, aliás, foram uma das primeiras estratégias para diagnosticar a aptidão de escolares, relacionados ao aumento da demanda social por escolas com a expansão do capitalismo na Europa. Quem primeiro se ocupou dessa questão foi a medicina, produzindo no final do século dezoito as classificações dos "anormais", ou aqueles que não aprendiam na escola. Tais classificações visavam medir as "aptidões naturais" dessas crianças, e obviamente desconsideravam qualquer responsabilidade que o meio social ou a escola pudesse ter sobre a aprendizagem das mesmas, tarefa em que se empenharam pesquisadores como Binet e Claparède, também na França. A ideia subjacente é identificar precocemente as "crianças anormais", para que possam ser encaminhadas ao ensino especializado e recebam "tratamento adequado". Inicialmente restrita à avaliação médica, a identificação dos "anormais escolares", como refere Patto (ibidem), ampliou-se com a chegada dos testes de inteligência ou de QI (quociente intelectual) às escolas, influenciando os educadores. No escopo das ideias psicanalíticas, particularmente no que se refere aos primeiros anos de vida, passou-se a dar maior peso às questões ambientais na avaliação dos alunos, valorizando-se a dimensão afetivo-emocional. A criança com problemas de aprendizagem e/ou comportamento passa de "anormal" para "criança problema", uma 
expressão típica dos anos 1930. Novas explicações para os "problemas" do aluno juntam-se às antigas, e a ordem passa a ser a "higiene mental escolar", visando corrigir de forma preventiva os "desajustes infantis" (PATTO, ibidem, p.67). Com isso, tornou-se comum a prática de encaminhar para psicólogos e médicos as crianças que não tinham um desempenho escolar satisfatório, de forma que fossem submetidas a diagnósticos, o que se recai na produção massiva de rótulos. Como bem destaca Patto (ibidem), o alvo dessas práticas são as crianças das classes trabalhadoras dos centros urbanos, que constituem a maioria dos "fracassados na escola" (p.67). A ênfase dada à hereditariedade desloca-se para a cultura, e as explicações para os baixos QIs dessas crianças passa da explicação das "raças inferiores" para a de "grupos culturais inferiores" - o que dá no mesmo, conforme Chauí (apud PATTO, ibidem). $\mathrm{Na}$ esteira dos movimentos reivindicatórios das minorias raciais norte-americanas, surge como resposta política a teoria da carência cultural, em que o ambiente é conceituado de forma acrítica, numa visão biologizada e etnocêntrica. As famílias das classes populares, portanto, ofereceriam ambientes inadequados, pouco estimulantes, não afetuosos e desmotivadores, e isso explicaria a performance tida como empobrecida na escola dos alunos provenientes dessas famílias.

No Brasil, os movimentos sociais que levaram à Revolução de 1930 caracterizaram-se por certo entusiasmo com a reforma da educação, sendo que os anos 1920 marcam uma tentativa de levar os ideais liberais para a educação pública por parte da elite progressista do país. Na década de 1930, ganha presença nos meios educacionais a teoria escolanovista, que surpreendentemente via mais nos métodos de ensino do que nas supostas deficiências dos alunos a origem das dificuldades de aprendizagem. No entanto, quando defendem a questão das diferenças individuais, os escolanovistas apontam para o caminho que a questão da diferença viria a tomar, ou seja: ao se reconhecer as diferenças, deve-se oferecer um ensino diferenciado, portanto especializado. De uma relação inicial de complementariedade entre pedagogia e psicologia, passa-se a considerar cada vez mais o fracasso escolar como distúrbio psicológico. Os diagnósticos passam a ser feitos com maior frequência por psicólogos ao invés dos médicos, embora não se possa esquecer que a psicologia brasileira nasce da medicina (PATTO, ibidem), portanto a mútua influência é constante. A teoria da carência cultural se fortalece no Brasil na década de 1970, visando explicar as diferenças entre as crianças da "classe média" e da "classe baixa". A explicação do fracasso escolar passa a ser que a escola era "inadequada para as crianças carentes", conforme 
Patto (1999), e portanto não poderiam se beneficiar dos mesmos métodos pedagógicos utilizados com crianças de classes mais favorecidas economicamente. Assim, a escola deveria utilizar métodos "adaptados" a esses alunos, deixando de "buscar um aluno ideal”. Fortalecese a teoria do déficit, em detrimento da teoria da diferença da Escola Nova.

Na conclusão de seu estudo, Patto (ibidem) aponta que a ideia de que o professor ensina baseado na suposição de um aluno ideal, supondo habilidades que ele não tem, necessita ser revista, uma vez que o problema da escola brasileira está muito mais em sua má qualidade, bem como na expectativa de que os alunos pobres não aprendam ou não tenham habilidades para isso. O discurso da incompetência do professor e do aluno apenas reforça as relações de dominação baseadas em ideias de superioridade/inferioridade. Mas para a discussão em pauta nesta tese a conclusão mais contundente de Patto (ibidem) é a de que o fracasso escolar é administrado por um discurso científico cujo objetivo é naturalizar esse fracasso aos olhos dos envolvidos no processo. A visão preconceituosa sobre as famílias justifica a ineficiência da ação pedagógica e alça as vítimas do processo à categoria de culpados. Ou seja: os alunos não aprendem por sua própria culpa. Culpa da sua herança genética, culpa do seu cérebro inapto.

Em pesquisa realizada em 1988, Moysés (2001) entrevistou diretores e professores de primeiro ano do Ensino Fundamental, bem como profissionais de saúde como psicólogos, médicos e fonoaudiólogos, em busca de suas concepções sobre o processo ensinoaprendizagem, o fracasso escolar e o papel dos profissionais de saúde em relação a isso. A autora observou que, independente da área de atuação, todos os profissionais atribuíam as causas do fracasso escolar às crianças e suas famílias, referindo problemas de ordem biológica para justificar o não-aprender na escola, segundo expressão de Moysés (ibidem). Na percepção das professoras entrevistadas, as causas da não-aprendizagem enfatizavam aspectos biológicos como desnutrição e doenças neurológicos (por exemplo, "disfunção cerebral mínima”), bem como "imaturidade", no sentido neurológico do termo, entre outras.

Outro dado interessante trazido pela autora é a análise do encaminhamento realizado para especialidades médicas após atendimento em unidades de saúde básica na rede pública de saúde em Campinas (SP), particularmente o encaminhamento para a neurologia (dados de 1995). Das consultas realizadas na faixa etária de 1 a 4 anos, cerca de 15\% eram de neurologia, enquanto que na população de 10 a 14 anos, cerca de $25 \%$ das consultas eram com o neurologista. Tais dados evidenciam um crescimento dos encaminhamentos a esse 
especialista, dados que, segundo Moysés (ibidem), contrariam o conhecimento da prevalência de afecções neurológicas na idade pediátrica, que ocorrem mais comumente nas idades mais precoces e tendem a diminuir com a idade (como se observa nos casos de epilepsia e convulsões, por exemplo). Espantosamente, o número de consultas de neurologia supera os de oftalmologia e otorrinolaringologia, que seriam mais esperadas na idade escolar. A autora relata ainda ter observado ser expressivo o número de crianças em seguimento com neurologistas nos serviços ambulatoriais oferecidos pela Universidade de Campinas Unicamp com o diagnóstico "distúrbio de aprendizagem".

A tentativa de transformar em doença as questões relacionadas à aprendizagem não é nova. Moysés e Collares (1992) apresentam o percurso histórico dos chamados “distúrbios de aprendizagem", alertando que tal expressão remete-se em sua origem a uma questão biológica, ao contrário do que possa parecer, dada a frequência com que é referida na escola. As autoras destacam que este conceito é uma "construção do pensamento médico", utilizando o caso da dislexia, ou melhor, dislexia específica de evolução (caracterizada pela dificuldade na aquisição da escrita), para exemplificar esse tipo de processo. A história de dislexia iniciou-se 1895 com a proposta de "cegueira verbal congênita" de Hinshelwood, oftalmologista inglês, passando em 1918 pela hipótese da "lesão cerebral mínima" de Strauss, neurologista norteamericano. Em 1925 é recuperado novamente, pelo neurologista americano Orton, o conceito de "cegueira verbal congênita", ocorrendo em 1957 o mesmo com o de "lesão cerebral mínima", também conhecida como "síndrome hipercinética" ou “hiperatividade", sendo passível de classificação clínica e medicação.

A partir dos experimentos do médico norteamericano Bradley em 1937 com a administração de anfetaminas a crianças (sem conhecimento ou consentimento de suas famílias, como apontam Moysés e Collares, ibidem), observou-se uma melhora da hiperatividade, o que, devido ao fato da anfetamina ser um estimulante do sistema nervoso, foi explicado por Bradley como devendo-se a um provável defeito na "substância reticular ativadora ascendente", o que deu um certo status a seu trabalho, ainda que baseado em suposições clínicas, e cujos resultados nem ele nem outro pesquisador conseguiram reproduzir. Ainda assim, a teoria adquiriu uma vida autônoma, como um neuromito, e de hipótese explicativa passou a teoria científica.

A denominação “disfunção cerebral mínima” surgiu na década de 1960 para substituir a antiga denominação de "lesão", uma vez que nenhum exame conseguia detectar 
lesões nas pessoas com tal diagnóstico. No entanto, como se arrolavam sob tais rótulos questões comportamentais, como distúrbio de aprendizagem, questões de coordenação motora e de concentração, entre outras, sem alterações objetivas observáveis, a saída encontrada foi presumir uma disfunção, ou alteração na função sem correspondência anatômica, mesmo sem evidências concretas de existência. No início da década de 1970, num momento histórico onde a biologização da sociedade é crescente (cite-se, por exemplo, o advento da psicocirugia ou lobotomia), a "disfunção cerebral mínima" é apresentada como um avanço, e logo o cenário social e educacional é dominado por essas ideias: "termos como hiperativo, DCM, distúrbio, dislexia, hipercinético invadem o cotidiano da sala de aula, infiltram-se na fala dos professores. A hipótese se transforma em verdade absoluta, incontestável. Em crença." (MOYSÉS; COLLARES, ibidem, p.40). Em 1980, a Academia Americana de Psiquiatria, considerando tais conceitos imprecisos, unificou-os sob o título de ADD (Attention Deficit Disorders), ou Distúrbios por Déficit de Atenção, podendo ser seguidos ou não por hiperatividade. Atualmente, no manual DSM-IV (Diagnostic and Statistical Manual of Mental Disorders, quarta edição) da Academia Americana de Psiquiatria, a sigla utilizada em português é TDA-H, ou Transtorno do Déficit de Atenção com (ou sem) Hiperatividade.

Já tive oportunidade de discutir ainda que brevemente no capítulo seis a questão da medicalização da sociedade e não pretendo ir além do que já foi exposto, mas considerei importante resgatar esse histórico documentado por Moysés e Collares (1992) para apontar que a história não acabou, infelizmente. O ponto crucial discutido nessa tese sobre o assunto é que a neurociência tem sido incorporada pela educação como mais um triste capítulo dessa história espúria. Desta vez, embalado em pesquisas moleculares e ressonâncias magnéticas, oferecendo a possibilidade de "olhar diretamente o cérebro", como afirmou a doutora Shankardass (discussão apresentada no capítulo seis). É o cruzamento da "última fronteira": vai-se mais além da culpabilização do aluno, mirando-se diretamente seus neurônios e neurotransmissores. Penso ter esclarecido que, na perspectiva histórico-cultural, tal procedimento é inadmissível, na medida em que considera o neurônio isolado do cérebro e por sua vez isolado do ser humano, num reducionismo biológico radicalmente oposto ao que Vigotski entendia ser a interpenetração do desenvolvimento biológico e cultural.

No que se refere à educação, e retomando algumas questões propostas no capítulo seis acerca da relação entre neurociência e educação, entendo que devo perfilar-me ao lado dos céticos. É óbvio que a ciência avança a passos largos, e a cada instante temos que rever 
nossas concepções que se tornaram ultrapassadas. Desta forma, não se trata de dar as costas ao que a neurociência vem produzindo no campo do conhecimento do cérebro, mas sim de observar essas descobertas com interesse científico, buscando conhecer mais esse envolvente universo do cérebro. Daí a querer aplicar tais descobertas na sala de aula é outra história. Apesar desse grande cabedal de conhecimentos, assim como Bruer (1997), entendo que a distância a ser coberta por essa ponte continua muito grande para nossos conhecimentos atuais de "engenharia". Portanto, creio que o educadores e pesquisadores em educação devem ser cautelosos, principalmente cuidando para que o diálogo com a neurociência se faça em bases que satisfaçam ambos os campos. Ou seja: a escola não devem esperar prescrições didáticas de neurocientistas, assim como já esperaram (ou esperam?) de médicos ou psicólogos para quem encaminharam seus alunos com supostas dificuldades de aprendizagem. Tampouco devem iniciar-se na neurociência, aspirando a um arremedo de neurocientista, e incluir termos como "plasticidade" e "epigênese" em seu discurso pedagógico. Conhecer neurociência, do jeito que estou propondo, tem muito mais a ver com uma alfabetização científica, que tanto pode suprir tal lacuna na formação de educadores quanto subsidiá-los para que adotem uma postura mais crítica em relação aos neuromitos e aos "neurométodos pedagógicos". Em relação aos pesquisadores em educação, entendo que também devem se defrontar com a tarefa de pesquisar as possíveis articulações entre neurociência e educação, ainda mais frente à crescente popularização dos neuromitos na escola. Assim, penso que a educação não deve excluir a neurociência, e sim, como disse Paulo Freire, ter uma "espera ativa", voltada para o conhecimento. Acrescento ainda que, se há alguma possibilidade remota de existir metodologias pedagógicas baseadas em achados da neurociência, elas somente terão credibilidade se forem montadas a partir de um trabalho colaborativo entre os dois campos, além de observar as etapas do processo consistente com uma pesquisa científica. Isso, acrescento, exigirá muito esforço de ambos os lados, uma vez que educação e neurociência tradicionalmente habitam campos epistemológicos distantes. No entanto, me parece um caminho muito mais potente e positivo para a educação do que recorrer à neurociência para buscar explicações de pretensas falhas nos alunos. Como procurei explicar, essa procura é ideológica, uma espécie de "upgrade" das teorias do dom, da carência cultural, da disfunção cerebral mínima e companhia. Esse tipo de recurso deve ser definitivamente expurgado da educação, e espero que a neurociência não se preste a sua manutenção.

Uma questão que também parece ter ficado mais bem esclarecida é o papel 
importante dos conhecimentos sobre o cérebro enquanto base material da consciência nos fundamentos da psicologia histórico-cultural proposta por Vigotski. A principal decorrência disso é que, numa tradição de interpretação do pensamento vigotskiano de cunho mais sociológico e pedagógico, como ocorre no Brasil, uma parte fundamental da teoria de Vigotski, aquela considerada indissociável da subjetiva, ou seja, a parte que se refere à base orgânica, não tem sido convenientemente incorporada na apreciação e estudo da obra do autor. Penso também que fica claro, como foi bem destacado por Wolfe (2009), que tal tradição alinha-se com uma certa rejeição daquilo que se refere ao estudo do cérebro como sendo mecanicista e reducionista, o que é uma interpretação apressada e pouco substanciosa. As diversas interpretações da obra de Vigotski já a entenderam de forma nem sempre compromissada com os fundamentos de sua teoria, mas há algo do qual nem os mais ecléticos poderiam despi-lo, que é seu materialismo e monismo. Portanto, o cérebro e seu funcionamento integrou e deve continuar integrando os fundamentos da psicologia históricocultural, em sua melhor tradição.

Isso nos coloca diante de uma tarefa nada fácil, que é entender o humano na sua materialidade e subjetividade de forma dialética. Mas, se não é fácil, também não é nova, pois continua a mesma proposta por Vigotski há cerca de oitenta anos.

Entendo que uma coisa é certa: não é possível manter uma teoria fecunda como a vigotskiana encastelada em seus supostos cânones, e entendo que uma teoria deve ser viva, como uma árvore que foi plantada em um passado distante e continua interagindo com seu ecossistema. Assim, a teoria vigotskiana nos dá prova de seu vigor na medida em que com ela enfrentamos e buscamos entender os dilemas do nosso tempo.

O conhecimento sobre o cérebro na atualidade é algo fascinante. Diariamente, surgem estudos trazendo novas informações, e a verdade nunca durou tão pouco como em nossos tempos, logo sendo substituída por uma nova temporária verdade, num processo contínuo. Tudo isso acontece numa sociedade caracterizada pelo ato que perpassa todo este estudo, que é o ato de educar, transmitindo a herança humana e constituindo assim a humanidade. A escola, permeável e permeando a sociedade, tem sede de saber sobre o cérebro, muitas vezes para continuar justificando seus fracassos através da culpabilização dos alunos, mas outras vezes por querer saber mais desse mundo misterioso que envolve o ensino e a aprendizagem. Quero acreditar que a segunda hipótese ganha forças, e continuará crescendo na medida em que possamos contribuir para o conhecimento crítico dos 
profissionais da educação, de forma que possam refletir sobre esses fenômenos de uma perspectiva mais ampla, evitando cair nas armadilhas ideológicas que usam a neurociência para justificar o fracasso escolar e culpabilizar quem quer que seja. A neurociência em si, como toda ciência, depende do uso que fazemos dela. Na escola, pode servir para encaminhar ao neurologista e buscar patologias, mas também pode servir para acreditar nas infinitas possibilidades de aprender graças à plasticidade cerebral. Gosto de pensar que a neurociência pode ser usada para o "bem", mas para isso temos que continuar a questionar essa tradição que enfileira historicamente patologias - TDA-H, disritmia, disfunção cerebral mínina e outros rótulos - e começar a buscar a potencialidade que o conhecimento sobre o cérebro pode trazer, se não para a sala de aula, para "abrir a cabeça" de educadores, pesquisadores e demais envolvidos na tarefa educativa.

Uma última palavra deve ser dita a respeito da aproximação que fiz entre as ideias de Vigotski e as descobertas atuais da neurociência. O fato é que muitas ideias de Vigotski estão sendo de alguma forma trazidas à tona e ressignificadas pelos achados da pesquisa neurocientífica hoje, como já apontei na introdução dessa tese - só para relembrar, a questão da imitação e os neurônios espelho, a incorporação de ferramentas, as conexões extracerebrais e outras. Não estou com isso querendo cometer um anacronismo, ou atribuir a Vigotski poderes proféticos. Gosto bastante da definição dada por Jonah Lehrer, jornalista, escritor e também neurocientista, ao apresentar seu livro Proust foi um neurocientista, onde relaciona obras de importantes artistas como Walt Whitman, Paul Cèzanne, Virginia Woolf e o já citado Marcel Proust, entre outros, como tendo proposto questões que agora estão sendo redescobertas pela neurociência, e que de alguma forma as anteciparam. Lehrer sublinha que, embora Whitman venerasse Einstein, e Proust e Woolf fizessem o mesmo em relação a Darwin, nunca deixaram de acreditar na necessidade da arte. Sendo mais uma vez ousada, acrescentaria à lista Vigotski e sua leitura de Shakespeare. Como diz Lehrer (2010, p.16), “a única realidade que a ciência não consegue reduzir é a única realidade que podemos conhecer. É por essa razão que necessitamos da arte". Não creio que haja dúvidas de que Vigotski concordaria com isso. 


\section{REFERÊNCIAS}

AKHUTINA, T. V. Vigotsky y A. R. Luria: la formación de la neuropsicología. Revista Española de Neuropsicología: [s.1.], v.4, n.2-3, p.108-129, 2002.

AKIMENKO, M. A. Vladimir Mikhailovich Bekhterev. Journal of the History of the Neurosciences, v.16, n.1-2, p.100-109, 2007.

ALMEIDA, S. H. V. Psicologia histórico-cultural da memória. 2008. 277 f. Tese (doutorado) - Pontifícia Universidade Católica de São Paulo. São Paulo, 2008.

ANSARI, D.; COCH, D. Bridges over troubled waters: education and cognitive neuroscience. Trends in Cognitive Sciences: [s.1.], v.10, n.4, p.146-151, abr. 2006. BAKHURST, D. Minds, Brains and Education. Journal of Philosophy of Education: [s.1.], v.42, n. 3-4, p.415-432, 2008.

BALDO, M. V. C.; HADDAD, H. Ilusões: o olho mágico da percepção. Revista Brasileira de Psiquiatria. [s.1.], n.25 (supl. II), p.6-11, 2003.

BENARÓS, S. et al. Neurociencia y educación: hacia la construcción de puentes interactivos. Revista de Neurología: [s.1.], v.3, n.50, p.179-186, 2010.

BENNETT, M. R.; HACKER, P. M. S. Fundamentos filosóficos da neurociência. Lisboa: Instituto Piaget, 2005.

BERITASHVILI, I. S. A modern interpretation of the mechanism of I. M. Sechenov's psychical reflex medium member. Progress in Brain Research, Netherlands, v.22 - Brain Reflexes, p.252-264, 1968.

BISPO, R. O sentimento do sentimento do que nos acontece: a consciência em Damásio. Galáxia: [s.1.], n.5, p.293-299, 2003.

BLACKMORE, S. Consciousness: a very short introduction. New York, EUA: Oxford University Press, 2005.

BLAKEMORE, S. J.; FRITH, U. The implications of recent developments in neuroscience for research on teaching and learning. London: Institute of Cognitive Neuroscience, 2000.

BLAKEMORE, S. J.; FRITH, U. The learning brain: lessons for education. Oxford: Blackwell, 2005. 
BLUNDEN, A. Vygotsky \& the Concept of Consciousness. Disponível em: <http://www. ethicalpolitics.org/wits/vygotsky-consciousness.pdf>. Acesso em 19 nov. 2011.

BONNER-JACKSON, A.; GROSSMAN, L. S.; HARROW, M.; ROSEN, C. Neurocognition in schizophrenia: a 20-year multi-follow-up of the course of processing speed and stored knowledge. Comprehensive Psychiatry. v.51, n.5, p.471-479, set./out. 2010.

BOTTOMORE, T. Dicionário do pensamento marxista. Rio de Janeiro: Jorge Zahar Editor, 1998.

BRANSFORD, J. et al. Learning theories and education: toward a decade of synergy. In: ALEXANDER, P. A.; WINNE, P. H. (Orgs.) Handbook of educational psychology. Mahwah, NJ, EUA: Lawrence Erlbaum Associates, 2006.

BRANSFORD, J. et al. Learning theories and education: toward a decade of synergy. The LIFE Center: The University of Washington, Stanford University \& SRI International, 2005.

BRUER, J. T. Education and the brain: a bridge too far. Educational Researcher: [s.1.], v.2, p. 4-16, 1997.

BUENO, J. U. O. A consciência como "ponto de partida". Paideia: [s.1.], v.12, n.22, p.83-87.

CAMPOS, A.; SANTOS, A. M. G.; XAVIER, G. F. A consciência como fruto da evolução e do funcionamento do sistema nervoso. Psicologia USP: São Paulo, v.8, n.2, 1997.

CANDIDO, C. A universidade e a sociedade do conhecimento digital. Disponível em:

<http://www.caosmose.net/candido/unisinos/textos/soconhedigital_vi_simposio.pdf >. Acesso em 31 dez. 2011.

CAREW, T. J.; MAGSAMEN, S. H. Neuroscience and Education: an ideal partnership for producing evidence-based solutions to guide 21st century learning. Neuron: [s.l.], n. 67, p.685-688, 9 set. 2010.

CARREIRAS, M. et al. An anatomical signature for literacy. Nature: [s.l.], v.461, n.15, p.983-988, out. 2009.

CARROLL, R. T. Dicionário Céptico (Skeptic's Dictionary). Tradução de Ronaldo Cordeiro. [2001]. Disponível em: <http://www.skepdic.com/brazil/mozart.html>. Acesso em 9 abr. 2011.

CESCON, E. O método interdisciplinar de investigação da consciência consciente de si.

Ciências \& Cognição: Rio de Janeiro, v.14, n.1, p.14-25, 2009.

$\mathrm{COCH}, \mathrm{D}$.; ANSARI, D. Thinking about mechanisms is crucial to connecting neuroscience and education. Cortex: [s.1.], v.45, n.4, p. 546-547, 2009. 
COELHO, L. M. S. Cérebro e psiquismo. Anais. I Conferência Internacional - O enfoque histórico cultural em questão. Santo André (SP), 2006.

COLE, M.; SCRIBNER, S. Introdução. In: VYGOTSKY, L. S. Formação social da mente. 4.ed. São Paulo: Martins Fontes, 1991.

COLLARES, C. A. L.; MOYSÉS, M. A. A. A transformação do espaço pedagógico em espaço clínico: a patologização da educação. In: ALVES, M. L. (Coord.) Cultura e saúde na escola. São Paulo: Fundação para o Desenvolvimento da Educação; 1994.

COSTA, V. C. I. Funções cerebrais superiores. Revista Távola Online: [s.1.], p.1-6, 2011. Disponível em <http://nucleotavola.com.br/revista/2011/03/01/funcoes-cerebraissuperiores/> . Acesso em 15 jun. 2011.

CSIBRA, G.; GERGELY, G. Social learning and social cognition: the case for pedagogy. In: MUNAKATA, Y.; JOHNSON, M. H. (Orgs.). Processes of change in brain and cognitive development. Attention and Performance, XXI. Oxford: Oxford University Press, 2006. DAVIS, A. Ian Hacking, learner categories and human taxonomies. Journal of Philosophy of Education: [s.1.], v.42, n. 3-4, p. 441-455, 2008.

DEÁK, C. Verbetes de economia política e urbanismo. [2005]. Disponível em <http://www.usp.br/fau/docentes/depprojeto /c_deak/CD/4verb/categoria/index.html> . Acesso em 21 nov. 2010.

DELARI JUNIOR, A. Discípulos involuntários de Descartes. Críticas de Vigotski a teorias dualistas das emoções. Umuarama: GETHC - Grupo de estudos em teoria histórico-cultural, 2009.

DELARI JUNIOR, A. Linha do tempo da psicologia russa/soviética em seu contexto sócio-político (em construção). Disponível em: <http://www.vigotski.net/ linhadotempo.html \#R26> acesso em 5 jul. 2010.

DELARI JUNIOR, A. O problema da subjetivação numa abordagem histórico-cultural: anotações iniciais para um trabalho de revisão crítica. Piracicaba (SP), 2001. Disponível em: <http://www.vigotski.net/probsubj.pdf>. Acesso em 15 ago. 2011.

DELLARI JUNIOR, A. Introdução a princípios metodológicos de L. S. Vigotski. Duas ou três sugestões para a pesquisa teórica em psicologia histórico-cultural. [2009]. Disponível em: < http://www.vigotski.net>. Acesso em 15 fev. 2011.

DEVONSHIRE, I. M.; DOMMET, E. J. Neuroscience: viable applications on education? The Neuroscientist: [s.1.], v.16, n.4, p.349-356, 2010.

DOMMETT, E. J. et al. From scientific theory to classroom practice. The Neuroscientist: [s.1.], v.20, n.10, p.1-7, 2009 
DUROZOI, G.; ROUSSEL, A. Dicionário de filosofia. Campinas (SP): Papirus, 1993.

EGIAZARYAN, G. G.; SUDAKOV, K. V. Theory of Functional Systems in the Scientific School of P. K. Anokhin. Journal of the History of the Neurosciences: [s.1.], v.16, n.1-2, p.194-205, 2007.

ELBERT, T.; PANTEV, C.; WIENBRUCH, C.; ROCKSTROH, B.; TAUB, E. Increased cortical representation of the fingers of the left hand in string players. Science: [s.l.], v.13, n.270 (5234), p.305-307, 1995.

ELHAMMOUMI, M. Is there a Marxist psychology? In: SAWCHUK, P.; ELHAMMOUMI, M.; DUARTE, N. Critical perspectives on activity: explorations across education, work, and everyday life. Nova York: Cambridge University Press, 2006.

ERAUT, M. Evidências baseadas nas práticas médicas e campos afins. In: THOMAS, G.; PRING, R. Educação baseada em evidências: a utilização dos achados científicos para a qualificação da prática pedagógica. Porto Alegre: Artmed, 2007.

FIGUEIREDO, L. C. Matrizes do pensamento psicológico. Petrópolis: Vozes, 1991.

FISCHER, K. W. et al. Why Mind, Brain, and Education ? Why now? Mind, Brain, and Education: [s.1.], v.1. n.1, p.1-2, 2007.

FISCHER, K. W.; GOSWAMI, U.; GEAKE, J. et al. The future of Educational Neuroscience. Mind, Brain, and Education: [s.1.], v.4, n.2, p.68-80, 2010.

FRANCO, A. O corpo e a aprendizagem humana. Educação e Comunicação: Leiria (Portugal), n.3, p.34-57, jun. 2000.

FROLOV, Y. P. [1937] Pavlov and his school: the theory of conditioned reflexes. Young Press, 2007. [reedição sobre original publicado em 1937 pela Oxford University Press].

GARAI, L. Vygotskian implications: on the meaning and its brain. The cultural-historical approach: progress in human sciences and education, Moscou, 1996.

GAZZANIGA, M. S.; IVRY, R. B.; MANGUN, G. R. Neurociência cognitiva: a biologia da mente. 2.ed. Porto Alegre: Artmed, 2006.

GEAKE, J. Neuromythologies in education. Educational Research: [s.1.], v.50, n. 2, p.123133, 2008. 
GEAKE, J.; COOPER, P. Cognitive Neuroscience: implications for education?

Westminster Studies in Education: [s.1.], v.26, n.1, p.7-20, 2003.

GENTILE, P. Geração multimídia. Nova Escola: jun. 2007. Disponível em:

<http://revistaescola.abril.com.br/online/ redatores/paola/>. Acesso em 15 ago. 2007.

GOSWAMI, U. Neuroscience and education: from research to practice? Nature Reviews Neuroscience | AOP [2006]. Disponível em: <www.nature.com/reviews/neuro>. Acesso em 26 dez. 2009.

GOSWAMI, U. Principles of learning, implications for teaching: a cognitive neuroscience perspective. Journal of Philosophy of Education: [s.1.], v.42, n. 3-4, p.381-399, 2008. GREENWOOD, R. Where are the educators? What is our role in the debate? [2008].

Cortex: [s.1.], v.45, n.4, p. 552-554, 2009.

GUERRA, L. B. O diálogo entre a neurociência e a educação: da euforia aos desafios e possibilidades. Interlocução: [s.1.], v.4, n.4, p.3-12, junho/2011.

GUIZZE, C. L. C. Jamais fomos modernos: uma reflexão sobre a modernidade e a atualidade. [2005]. Disponível em < http://www.fau.ufrj.br/prolugar/arq_pdf/

diversos/jamaisfomosmodernos.pdf >. Acesso 12 nov. 2011.

HAMMERSLEY, M. Algumas questões sobre a prática baseada em evidências na educação. In: THOMAS, G.; PRING, R. Educação baseada em evidências: a utilização dos achados científicos para a qualificação da prática pedagógica. Porto Alegre: Artmed, 2007.

HOLLAND, D.; LACHICOTTE JR, W. Vygotsky, Mead, and the new sociocultural studies of identity. In: DANIELS, H.; COLE, M.; WERTSCH, J. V. The Cambridge companion to Vygotsky. New York, EUA: Cambridge University Press, 2007.

HOWARD-JONES, P. A. Education and neuroscience. Educational Research: n.50, v.2, p.119-122, 2008.

HUNG, D. Supporting current pedagogical approaches with neuroscience research. Journal of Interactive Learning Research: Norfolk (EUA), v.14, n.2, p.129-155, 2003.

IWAO, S. The Development of the Mind as Psychological Systems. Journal of Russian and East European Psychology. [s.1.], v.34, n.1, p. 6-15, 1996.

KICHIGINA, G. The imperial laboratory - experimental physiology and clinical medicine in post-crimean Russia. Amsterdan-new York: Rodopi, 2009.

KNOX, J. E. Prefácio. In: VYGOTSKY, L. S.; LURIA, A. R. [1930] Estudos sobre a história do comportamento: símios, homem primitivo e a criança. Porto Alegre: Artes Médicas, 1996.

LEHRER, J. Proust foi um neurocientista: como a arte antecipa a ciência. Rio de Janeiro: BestSeller, 2010.

LENT, R. Cem bilhões de neurônios: conceitos fundamentais de neurociência. Edição revisada. Rio de Janeiro: Atheneu, 2004. 
LEVITIN, K. One is not born a personality. Profiles of soviet educational psychologists. [1982]. Disponível em <http://www.marxists.org/subject/psychology/works/levitin/not-bornpersonality.pdf>. Acesso em 15 abr. 2010.

LORDELO, L. R.; TENÓRIO, R. M. A consciência na obra de L. S. Vigotski: análise do conceito e implicações para a Psicologia e a Educação. Revista Semestral da Associação Brasileira de Psicologia Escolar e Educacional: São Paulo, v.14, n.1, p.79-8, 2010.

LURIA, A. R. Desenvolvimento cognitivo. São Paulo: Ícone, 1990.

LURIA, A. R. Fundamentos de neuropsicologia. Rio de Janeiro: Livros Técnicos e Científicos; São Paulo: Editora da Universidade de São Paulo, 1981.

LURIA, Alexander R. O cérebro humano e a atividade consciente. [197?] In: VIGOTSKII, L.; LURIA, A.; LEONTIEV, A. Linguagem, desenvolvimento e aprendizagem. 4.ed. São Paulo: Ícone, 1992.

LUZ, M. T. Natural, racional, social: razão médica e racionalidade científica moderna. Rio de Janeiro, Campus, 1988. Disponível em: <http://www.histedbr.fae.unicamp.br/navegando/ glossario/verb_c_medicalizacao.htm>. Acesso em 21 set. 2011.

LUZ, M. T. Racionalidades médicas: diagnose e terapêutica: médicos e pacientes no dia-adia institucional. Rio de Janeiro, Departamento de Planejamento e Administração em Saúde, Instituto de Medicina Social, UERJ, 1997. Disponível em: <http://www.histedbr.fae. unicamp.br/ navegando/glossario/verb_c_medicalizacao.htm>. Acesso em 21 set. 2011.

MARX, K. Capítulo VII - O processo de trabalho e processo de produção de mais valia. In: . O capital. v.1 - parte III. Disponível em: <http://www.marxists.org/portugues/ marx/ 1867/ ocapital-v1/vollcap07.htm>. Acesso em 26 mar. 2011.

MASON, L. Bridging neuroscience and education: A two-way path is possible. Cortex: [s.1.], v.45, n.4, p. 548-549, 2009.

MEIJER O. G.; BRUIJN, S. M. The loyal dissident: N.A. Bernstein and the double-edged sword of Stalinism. Journal of the History of the Neurosciences, v.16, n.1-2, p. 206-224, 2007.

MERLEAU-PONTY, M. Fenomenologia da percepção. 2.ed. São Paulo: Martins Fontes, 1999.

MESHCHERYAKOV, B. G. Terminology in L. S. Vygotsky's Writings. In: COLE, M.; DANIELS, H.; WERTSCH, J.V. (eds.) The Cambridge companion to Vygotsky.

Cambridge, New York: Cambridge Universsity Press, 2007.

MINICK, N. The early history of the Vygotskian school: the relationship between mind and activity. In: COLE, M.; ENGESTROM, Y.; VASQUEZ, O. Mind, Culture, and Activity Seminal Papers from the Laboratory of Comparative Human Cognition. Cambridge, UK: Cambridge University Press, 1997. 
MOLL, L. C. Vygotsky e a educação: implicações pedagógicas da psicologia sóciohistórica. Porto Alegre : Artes Médicas, 2002.

MORALES, R. Educação e neurociências: uma via de mão dupla. $28^{a}$ reunião Anped, Caxambu (MG), 2005.

MOYSÉS, M. A. A. A institucionalização invisível: crianças que não-aprendem-na-escola. Campinas (SP): Mercado de Letras; São Paulo: Fapesp, 2001.

MOYSÉS, M. A. A.; COLLARES, C. A. L. A história não contada dos distúrbios de aprendizagem. Cadernos Cedes: Campinas (SP), n.28, p.34-47, 1992.

MOYSÉS, M. A. A.; COLLARES, C. A. L. Dislexia e TDAH: uma análise a partir da ciência médica. In: CRP-SP; GIQE. Medicalização de crianças e adolescentes: conflitos silenciados pela redução de questões sociais a doenças de indivíduos. São Paulo: Casa do Psicólogo, 2010.

OCDE - Organização de Cooperação e Desenvolvimento Econômico. Compreendendo o cérebro: rumo a uma nova ciência da aprendizagem. São Paulo: Editora Senac, 2003.

OECD - Organisation for Economic Co-operation and Development. Understanding the Brain: The Birth of a Learning Science. Paris, França: Centre for Educational Research and Innovation, OECD Publishing, 2007.

OLIVEIRA, M. K.; REGO, T. C. Contribuições da perspectiva histórico-cultural de Luria para a pesquisa contemporânea. Educação e Pesquisa: São Paulo, v.36, n. especial, p. 107$121,2010$.

OLIVEIRA, M. K.; TEIXEIRA, E. A questão da periodização do desenvolvimento psicológico. In: OLIVEIRA, M. K.; REGO, T. C.; SOUZA, D. T. R. (Orgs.) Psicologia, educação e as temáticas da vida contemporânea. São Paulo: Moderna, 2002.

OLIVEIRA, Marta Kohl de. Vygotsky: aprendizado e desenvolvimento: um processo sóciohistórico. 5.ed. São Paulo: Scipione, 2010.

PATTO, M. H. S. A produção do fracasso escolar: histórias de submissão e rebeldia. São Paulo: Casa do Psicólogo, 1999.

PEREIRA, D. Lenin e a dialética hegeliana. [2004]. Disponível em <http://www. acessa. com/ gramsci/?page=visualizar\&id=110> . Acesso 12 nov. 2011 . 
PINO, A. As marcas do humano: às origens da constituição cultural da criança na perspectiva de Lev. S. Vigotski. São Paulo: Cortez, 2005.

PINO, A. The beginnings of a child's cultural constitution. Revista de Etologia, v.4, n.2, p.117-127, 2002.

PUZIREI, A. A. Lev S. Vigotski: Manuscrito de 1929 (introdução). Educação \& Sociedade, ano XXI, no $71,2000$.

RAHMANI, L. A note about I. M. Sechenov. In: SECHENOV, I. M. I. M. Sechenov: biographical sketch and essays. [S.l. Coleção Classics in Psychology, baseada na obra selecionada do autor, publicada em 1935 em Moscou], Arno Press, 1973.

RATO, J. R.; CALDAS, A. C. Neurociências e educação: realidade ou ficção? Portugal: Actas do VII Simpósio Nacional de Investigação em Psicologia, Universidade do Minho, p.626-644, 2010.

REGO, T. C. R. Resenha. L.S. Vygotsky, A.R. Luria. Estudos sobre a história do comportamento: símios, homem primitivo e criança. Revista Brasileira de Educação, [s.1.], n.2, p.93-95, mai-ago 1996.

RIVIÈRE, A. La psicología de Vygotski: sobre La larga proyección de uma corta biografia. Infancia y Aprendizaje: v.27/28, p.7-86, 1984.

ROBINS, D. Prologue. In: The Collected Works of L. S. Vygotsky.

Volume 6: Scientific Legacy. Kluwer Academic/Plenum Publishers: New York, 1999.

ROSSETTI-FERREIRA, M. C.; AMORIM, K. S.; SOARES-SILVA, A. P.; OLIVEIRA, Z. M. R. Desafios metodológicos na perspectiva da Rede de Significações. Cadernos de Pesquisa: São Paulo, v. 38, n. 133, p. 147-170, 2008.

SACKS, O. O caso do pintor daltônico. In: SACKS, O. Um antropólogo em Marte. São Paulo: Cia das Letras, 1995.

SACKS, O. Um antropólogo em Marte. São Paulo: Companhia da Letras, 2006.

SAMOILOV, V. O. Ivan Petrovich Pavlov (1849-1936). Journal of the History of the Neurosciences: [s.1.], v.16, n.1-2, p.74-89, 2007. 
SAMUELS, B. M. Can the differences between education and neuroscience be overcome by Mind, Brain, and Education? Mind, Brain, and Education: [s.1.], v.3, n.1, p. 45-55, 2009. SCHRAG, F. Does neuroscience matter for education? Educational Theory: Illinois (EUA), v.61, n. 2, p.221-237, 2011.

SCHULTZ, D. P.; SCHULTZ, S. E. História da psicologia moderna. 5.ed. São Paulo: Cultrix, 1992.

SHTERENSHIS, M.; VAIMAN, M. European influence on Russian neurology. Journal of the History of the Neurosciences, vol.16, n.1-2, p.6-18, 2007.

SHUARE, M. La psicología soviética tal como yo la veo. Moscou: Editorial Progreso, 1990.

SILVONEN, J. Vygotsky's plural discourse on the human mind. [ISCAR, 2005].

Disponível em <http://lchc.ucsd.edu/mca/Paper/Vygotsky_still_alive_JS_final.pdf $>$. Acesso em 20 ago. 2011.

SIRGADO, A. P. A corrente sócio-histórica de psicologia: fundamentos epistemológicos e perspectivas educacionais. Em Aberto: Brasília, ano 9, n.48, p.61-67, out./dez. 1990.

SIRGADO, A. P. O social e o cultural na obra de Vigotski. Educação \& Sociedade. ano XXI, n.71, p.45-78, jul. 2000.

SMITH, H. A. Da homogeneidade biológica à heterogeneidade cultural: o papel da construção de significados no desenvolvimento humano. Educar: Curitiba, n.14, p.115-136, 1998.

SMOLKA, A. L. B. A concepção de linguagem como instrumento: Um questionamento sobre práticas discursivas e educação formal. Temas em Psicologia: [s.1.], n.1, p.11-22, 1995.

SMOLKA, A. L. B. O (im)próprio e o (im)pertinente na apropriação das práticas sociais.

Cadernos Cedes: Campinas (SP), ano XX, n.50, p.26-40, 2000.

SOUZA JÚNIOR, E. J. Reflexologia soviética e teoria histórico-cultural: uma análise das interlocuções entre o pensamento de Vigotski e o pavlovianismo. Dissertação de Mestrado. UFMG: Belo Horizonte, 2008.

SOUZA JUNIOR, E. J.; CIRINO, S. D. Revisitando a reflexologia soviética. Mnemosine, Rio de Janeiro, v.5, n.2, p.131-161, 2009. 
SPARROW, B.; LIU, J.; WEGNER, D. M. Google effects on memory: cognitive consequences of having information at our fingertips. Science: [s.1.], v.333, n.6043, p.776778, 5 ago. 2011.

SPIERS, H. J.; MAGUIRE, E. A Thoughts, behaviour and brain dynamics during navigation in the real world. NeuroImage: [s.1.], v. 31, p. 1826-1840, 2006.

STERN, E. Pedagogy meets neuroscience. Science: [s.1.], v.310, n.5749, p.745, 4 nov. 2005.

STERnBERG, R. J. Psicologia cognitiva. São Paulo: Cengage Learning, 2010.

SZÜCS, D.; GOSWAMI, U. Educational neuroscience: defining a new discipline for the study of mental representations. Mind, Brain and Education: [s.l.], v.1, n.3, p.114-127, 2007.

TEIXEIRA, E. Vigotski e o materialismo dialético: uma introdução aos fundamentos filosóficos da Psicologia Histórico-Cultural. Pato Branco: FADEP, 2005.

TEPPER, H. The controversial science of free will. Entrevista com Michael B. Gazzaniga. Disponível em: <http://www.salon.com/2011/11/13/the_controversial_science_ of_free_will/singleton/>. Acesso em 13 nov. 2011.

THEODORIDOU, Z. D.; TRIARHOU, L. C. Fin-de-siècle advances in neuroeducation: Henry Herbert Donaldson and Reuben Post Halleck. Mind, Brain, and Education: [s.l.], v.3, n.2, p.119-129, 2009.

THOMAS, G. Introdução: evidências e prática. In: THOMAS, G.; PRING, R. Educação baseada em evidências: a utilização dos achados científicos para a qualificação da prática pedagógica. Porto Alegre: Artmed, 2007.

THOMPSON, R. F. O cérebro - uma introdução à neurociência. 3.ed. São Paulo: Livraria Santos Editora, 2005.

TOKUHAMA-ESPINOSA, T. Mind, brain and education science: a comprehensive guide to the new brain-based teaching. New York, EUA: W. W. Norton \& Company, Inc., 2011. TOKUHAMA-ESPINOSA, T. The new science of teaching and learning: using the best of mind, brain and education science in the classroom. New York, EUA: Teachers College Press, 2010.

TUPPER, D. E. Introduction: Alexander Luria's continuing influence on worldwide neuropsychology. Neuropsycholosy Review: [s.1.], v.9, n.1, 1999.

VAN DER VEER, R. Vygotsky in context: 1900-1935. In: COLE, M.; DANIELS, H.; WERTSCH, J.V. (eds.) The Cambridge companion to Vygotsky. Cambridge, New York: Cambridge Universsity Press, 2007.

VAN DER VEER, R.; VALSINER, J. Vygotsky: uma síntese. 4.ed. São Paulo: Loyola, 2001. 
VEIN, A. A. Introduction. Journal of the History of the Neurosciences: [s.1.], v.16, n.1-2, p.2-5, 2007.

VERENIKINA, I. Understanding scaffolding and the ZPD in educational research. Faculty of Education, University of Wollongong, NSW, Australia, 2003. Disponível em: <https://www.aare.edu.au/03pap/ver03682.pdf>. Acesso em 20 ago. 2011.

VERESOV, N. Comments on Andy Blunden's paper "Vygotsky and the concept of consciousness". [2011]. Disponível em <http://nveresov.narod.ru/Consciousness.pdf>. Acesso em 1 set. 2011.

VERESOV, N. Undiscovered Vygotsky. Etudes on the pre-history of cultural-historical psychology. Frankfurt am Main: Peter Lang, 1999.

VIGOTSKI, L. S. (1924-1926) Os métodos de investigação reflexológicos e psicológicos. In: . Teoria e método em psicologia. 3.ed. São Paulo: Martins Fontes, 2004.

VIGOTSKI, L. S. (1925) A consciência como problema da psicologia do comportamento. In: . Teoria e método em psicologia. 3.ed. São Paulo: Martins Fontes, 2004.

VIGOTSKI, L. S. (1926) Psicologia pedagógica. 3.ed. São Paulo: Martins Fontes, 2010.

VIGOTSKI, L. S. (1927) O significado histórico da crise da psicologia. In:

Teoria e método em psicologia. 3.ed. São Paulo: Martins Fontes, 2004.

VIGOTSKI, L. S. (1929) Manuscrito de 1929. Educação \& Sociedade: Campinas (SP), ano XXI, n $71,2000$.

VIGOTSKI, L. S. (1930a) Sobre os sistemas psicológicos. In: Teoria e método em psicologia. 3.ed. São Paulo: Martins Fontes, 2004.

VIGOTSKI, L. S. (1930b) A psique, a consciência, o inconsciente. In: Teoria e método em psicologia. 3.ed. São Paulo: Martins Fontes, 2004.

VIGOTSKI, L. S. (1930c) O método instrumental em psicologia. In: Teoria e método em psicologia. 3.ed. São Paulo: Martins Fontes, 2004. 
VIGOTSKI, L. S. (1931) Desenvolvimento da memória (prefácio ao livro de A N. Leóntiev). In: . Teoria e método em psicologia. São Paulo, Martins Fontes, 2004.

VIGOTSKI, L. S. (1931) O pensamento na esquizofrenia. Tradução didática de Achiles Dellari Junior (2008). Disponível em: <http://www.4shared.com/file/50287419/9ebb7f5b/ Traduo_de_Vigotski_O_Pensamento_na_Esquizofrenia.html?s=1>. Acesso em 26 dez. 2010.

VIGOTSKI, L. S. (1933) Aprendizagem e desenvolvimento intelectual na idade escolar. In: LEONTIEV, A. N.; LURIA, A. R.; VIGOTSKI, L. S. Linguagem, desenvolvimento e aprendizagem. 4.ed. São Paulo: Ícone, 1992.

VIGOTSKI, L. S. (1934) A psicologia e a teoria da localização das funções psíquicas. In: . Teoria e método em psicologia. São Paulo, Martins Fontes, 2004.

VIGOTSKI, L. S. A defectologia e o estudo do desenvolvimento e da educação da criança anormal. Educação e Pesquisa: São Paulo, v.37, n.4, dez. 2011.

VIGOTSKI, L. S. A formação social da mente. 7.ed. São Paulo: Martins Fontes, 2007.

VIGOTSKII, L. S. Aprendizagem e desenvolvimento intelectual na idade escolar. In: VIGOTSKII, L.; LURIA, A.; LEONTIEV, A. Linguagem, desenvolvimento e aprendizagem. 4.ed. São Paulo: Ícone, 1992.

VIGOTSKY, L. S. (1931) Teoria de las emociones: estudio histórico-psicológico. Madrid: Ediciones Akal, 2004.

VYGODSKAIA, G. L.; LIFANOVA, T. M. Lev Semenovitch Vygotsky. Journal of Russian and East European Psychology. v.37, n.2, 1999.

VYGOTSKI, L. S. (1926) Prólogo a la versión rusa del libro de E. Thonrdike "Princípios de eseñanza basados en la psicología". In: . Obras escogidas. Obras escogidas, vol. I. Madri, 1991.

VYGOTSKI, L. S. (1928) Anomalías del desarrollo cultural del nino. In: Fundamentos de defectología. Obras escogidas, vol. V. Madri, 1997. 
VYGOTSKI, L. S. (1929) El problema del desarrollo cultural del niño. [In: Luciano Mecacci (org). La psicologia sovietica 1917-1936. Roma: Editori Riuniti, 1976]. Tradução de Efraín Aguilar (2008). Disponível em: < http://vygotski-traducido.blogspot.com>. Acesso em 7 maio 2010.

VYGOTSKI, L. S. (1931). Historia del desarrollo de las funciones psíquicas superiores. 2ed. Obras escogidas, vol. III. Madri: Visor, 2000.

VYGOTSKI, L. S. (1931-1933) Spinoza y su teoría de las emociones a la luz de la psiconeurología contemporânea. Tradução de Efraín Aguilar. (2008). Disponível em: $<$ http://vygotski-traducido.blogspot.com/>. Acesso em 4 maio 2010.

VYGOTSKI, L. S. (1931a) Paidologia del adolescente. Capítulo 10: El desarollo del pensamiento del adolescente y la formación de conceptos. In: Obras escogidas, v.4. Madrid: Visor, 1997.

VYGOTSKI, L. S. (1932) El primero ano. In: Obras escogidas, v.4. Madrid: Visor, 1997.

VYGOTSKI, L. S. (1934) El problema de el desarrollo y la desintegración de las funciones psíquicas superiores. [In: Luciano Mecacci (org). La psicologia sovietica 19171936. Roma: Editori Riuniti, 1976]. Tradução de Efraín Aguilar (2008). Disponível em: < http://vygotski-traducido.blogspot.com>. Acesso em 7 maio 2010.

VYGOTSKY, L. S. (1929) The problem of the cultural development of the child. Disponível em: < http://www.marxists.org/archive/ vygotsky/ works/ 1929/ cultural_development.htm >. Acesso em 4 maio 2010.

VYGOTSKY, L. S. (1931) The Teaching about Emotions. Historical-Psychological Studies. In: . The Collected Works of L. S. Vygotsky. Volume 6: Scientific Legacy.

Kluwer Academic/Plenum Publishers: New York, 1999.

VYGOTSKY, L. S. (1932) The mind-body problem. From the notebooks of L. S. Vygotsky. [1977, organizado por Puzirei]. p.12-15. Disponível em: < http://www.vigotski.net >. Acesso em 20 mar. 2010.

VYGOTSKY, L. S. (1934) On localization. From the notebooks of L. S. Vygotsky. [1977, organizado por Puzirei]. p.15-17. Disponível em: < http://www.vigotski.net >. Acesso em 20 mar. 2010. 
VYGOTSKY, L. S.; LURIA, A. R. (1930) Estudos sobre a história do comportamento: símios, homem primitivo e a criança. Porto Alegre: Artes Médicas, 1996.

WERTSCH, J. V. Vygotsky y La formación social de la mente. Barcelona, Espanha: Paidós, 1988.

WILLINGHAM, D. T. Three problems in the marriage of neuroscience and education [2008]. Cortex: [s.1.], v.45, n.4, p. 544-545, 2009.

WILLINGHAM, D. T.; LLOYD, J. W. How educational theories can use neuroscientific data. Mind, Brain, and Education: [s.1.], v.1, n.3, p.140-149, 2007.

WOLFE, C. T. The social brain: a Spinozist reconstruction. ASCS09: Proceedings of the 9th Conference of the Australasian Society for Cognitive Science, p.366-374, 2009. Disponível em [DOI]: <10.5096/ASCS200956>. Acesso em 10 nov. 2011.

YAROSHEVSKY, M. C. Epilogue. In: The Collected Works of L. S. Vygotsky. Volume 6: Scientific Legacy. Kluwer Academic/Plenum Publishers: New York, 1999.

YASNITSKY, A. Vygotsky circle during the decade of 1931-1941: toward an integrative science of mind, brain, and education. Tese (doutorado), 147p. Department of Curriculum, Teaching and Learning, Ontario Institute for Studies in Education, University of Toronto, 2009. 


\section{Apêndice 1 - Referências completas das obras analisadas}

\section{$\mathbf{1}^{\mathbf{0}}$ momento}

Palavras-chave: REFLEXO E CONSCIÊNCIA

Textos produzidos entre 1924 e 1926

1924 Os métodos de investigação reflexológicos e psicológicos

VIGOTSKI, L. S. (1924-1926) Os métodos de investigação reflexológicos e psicológicos. In: . Teoria e método em psicologia. 3.ed. São Paulo: Martins Fontes, 2004.

1925 A consciência como problema da psicologia do comportamento

VIGOTSKI, L. S. (1925) A consciência como problema da psicologia do comportamento. In: . Teoria e método em psicologia. 3.ed. São Paulo: Martins Fontes, 2004.

1926 Prólogo à versão russa do livro de E. Thorndike, "Princípios de ensino baseados na psicologia"

VYGOTSKI, L. S. (1926) Prólogo a la versión rusa del libro de E. Thonrdike "Princípios de eseñanza basados en la psicología". In: Obras escogidas. Obras escogidas, vol. I.

Madri, 1991.

1926 Psicologia pedagógica

VIGOTSKI, L. S. (1926) Psicologia pedagógica. 3.ed. São Paulo: Martins Fontes, 2010.

\section{$2^{\mathbf{0}}$ momento}

Palavra-chave: INSTRUMENTO

Textos produzidos entre 1929 e 1930

1929 Manuscrito de 1929

VIGOTSKI, L. S. (1929) Manuscrito de 1929. Educação \& Sociedade, ano XXI, no 71, 2000. 
VYGOTSKI, L. S. (1929) El problema del desarrollo cultural del niño. [In: Luciano Mecacci (org). La psicologia sovietica 1917-1936. Roma: Editori Riuniti, 1976]. Tradução de Efraín Aguilar (2008). Disponível em: < http://vygotski-traducido.blogspot.com>. Acesso em 7 maio 2010.

VYGOTSKY, L. S. (1929) The problem of the cultural development of the child.

Disponível em: < http://www.marxists.org/archive/ vygotsky/ works/ 1929/

cultural_development.htm >. Acesso em 4 maio 2010.

1930 A psique, a consciência, o inconsciente

VIGOTSKI, L. S. (1930b) A psique, a consciência, o inconsciente. In: Teoria e método em psicologia. 3.ed. São Paulo: Martins Fontes, 2004.

1930 O método instrumental em psicologia

VIGOTSKI, L. S. (1930c) O método instrumental em psicologia. In: Teoria e método em psicologia. 3.ed. São Paulo: Martins Fontes, 2004.

1930 Sobre os sistemas psicológicos

VIGOTSKI, L. S. (1930a) Sobre os sistemas psicológicos. In: Teoria e método em psicologia. 3.ed. São Paulo: Martins Fontes, 2004.

1930 Estudos da história do comportamento: símios, homem primitivo e criança.

VYGOTSKY, L. S.; LURIA, A. R. (1930) Estudos sobre a história do comportamento: símios, homem primitivo e a criança. Porto Alegre: Artes Médicas, 1996.

\section{$3^{\circ}$ momento}

Palavra-chave: FUNÇÕES PSICOLÓGICAS SUPERIORES

Textos produzidos entre 1931 e 1933

1931 História do desenvolvimento das funções psíquicas superiores

VYGOTSKI, L. S. (1931). Historia del desarrollo de las funciones psíquicas superiores. 2ed. Obras escogidas, vol. III. Madri: Visor, 2000. 
1931 Psicologia educacional [paidologia] do adolescente

VYGOTSKI, L. S. (1931a) Paidologia del adolescente. Capítulo 10: El desarollo del pensamiento del adolescente y la formación de conceptos. In: Obras escogidas, v.4. Madrid: Visor, 1997.

1932 O primeiro ano

VYGOTSKI, L. S. (1932) El primero ano. In: Obras escogidas, v.4. Madrid:

Visor, 1997.

1931-1933 Teoria das emoções

VIGOTSKY, L. S. (1931) Teoria de las emociones: estudio histórico-psicológico. Madrid: Ediciones Akal, 2004.

VYGOTSKI, L. S. (1931-1933) Spinoza y su teoría de las emociones a la luz de la psiconeurología contemporânea. Tradução de Efraín Aguilar. (2008). Disponível em: <http://vygotski-traducido.blogspot.com/>. Acesso em 4 maio 2010.

VYGOTSKY, L. S. (1931) The Teaching about Emotions. Historical-Psychological Studies. In: The Collected Works of L. S. Vygotsky. Volume 6: Scientific Legacy. Kluwer Academic/Plenum Publishers: New York, 1999.

\section{$4^{0}$ momento}

Palavra-chave: CÉREBRO

Textos produzidos entre 1932 e 1934

1932 O problema mente-corpo

VYGOTSKY, L. S. (1932) The mind-body problem. From the notebooks of L. S. Vygotsky. [1977, organizado por Puzirei]. p.12-15. Disponível em: < http://www.vigotski.net >. Acesso em 20 mar. 2010.

1934 A psicologia e a teoria da localização das funções psíquicas

VIGOTSKI, L. S. (1934) A psicologia e a teoria da localização das funções psíquicas. In: . Teoria e método em psicologia. São Paulo, Martins Fontes, 2004. 
VYGOTSKY, L. S. (1934) On localization. From the notebooks of L. S. Vygotsky. [1977, organizado por Puzirei]. p.15-17. Disponível em: < http://www.vigotski.net >. Acesso em 20 mar. 2010.

1934 O problema do desenvolvimento e da desintegração das funções psíquicas superiores

VYGOTSKI, L. S. (1934) El problema de el desarrollo y la desintegración de las funciones psíquicas superiores. [In: Luciano Mecacci (org). La psicologia sovietica 19171936. Roma: Editori Riuniti, 1976]. Tradução de Efraín Aguilar (2008). Disponível em: < http://vygotski-traducido.blogspot.com>. Acesso em 7 maio 2010.

1934 O pensamento na esquizofrenia

VIGOTSKI, L. S. (1931) O pensamento na esquizofrenia. Tradução didática de Achiles Dellari Junior (2008). Disponível em: <http://www.4shared.com/file/50287419/9ebb7f5b/ Traduo_de_Vigotski_O_Pensamento_na_Esquizofrenia.html?s=1>. Acesso em 26 dez. 2010.

1934 Para o problema da demência no Mal de Pick

Não consultado no original (ver explicação na p.156 ). 